\title{
Diffusion and Leaching Behavior of Radionuclides in Category 3 Waste Encasement Concrete and Soil Fill Material - Summary Report
}
SV Mattigod
LN Clayton
DM Wellman
L Powers
CC Bovaird KP Recknagle
KE Parker
MI Wood

August 2011

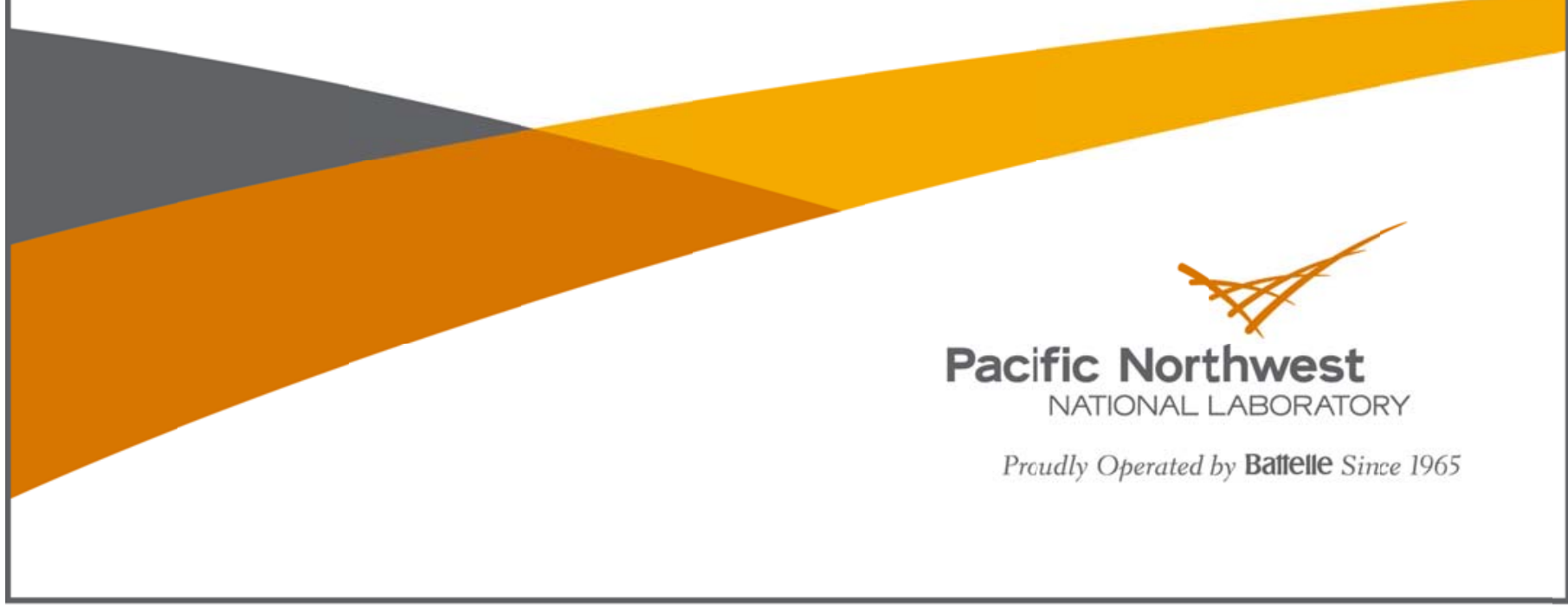




\title{
DISCLAIMER
}

This report was prepared as an account of work sponsored by an agency of the United States Government. Neither the United States Government nor any agency thereof, nor Battelle Memorial Institute, nor any of their employees, makes any warranty, express or implied, or assumes any legal liability or responsibility for the accuracy, completeness, or usefulness of any information, apparatus, product, or process disclosed, or represents that its use would not infringe privately owned rights. Reference herein to any specific commercial product, process, or service by trade name, trademark, manufacturer, or otherwise does not necessarily constitute or imply its endorsement, recommendation, or favoring by the United States Government or any agency thereof, or Battelle Memorial Institute. The views and opinions of authors expressed herein do not necessarily state or reflect those of the United States Government or any agency thereof.

\author{
PACIFIC NORTHWEST NATIONAL LABORATORY \\ operated by \\ BATTELLE \\ for the \\ UNITED STATES DEPARTMENT OF ENERGY \\ under Contract DE-AC05-76RL01830
}

Printed in the United States of America
Available to DOE and DOE contractors from the Office of Scientific and Technical Information,
P.O. Box 62, Oak Ridge, TN 37831-0062;
ph: $(865)$ 576-8401
fax: $(865) 576-5728$
email: reports@adonis.osti.gov
Available to the public from the National Technical Information Service
5301 Shawnee Rd., Alexandria, VA 22312 ph: (800) 553-NTIS (6847)
email: orders@ntis.gov <http://www.ntis.gov/about/form.aspx>
Online ordering: http://www.ntis.gov

This document was printed on recycled paper. 


\title{
Diffusion and Leaching Behavior of Radionuclides in Category 3 Waste Encasement Concrete and Soil Fill Material - Summary Report
}

\author{
SV Mattigod \\ LN Clayton \\ DM Wellman \\ L Powers \\ CC Bovaird \\ KP Recknagle \\ KE Parker \\ MI Wood
}

August 2011

Prepared for

the U.S. Department of Energy

under Contract DE-AC05-76RL01830

Pacific Northwest National Laboratory

Richland, Washington 99352 



\section{Acknowledgments}

We thank S.R. Baum, and E.T. Clayton for conducting ICP-OES and ICP-MS analyses, respectively. 



\section{Acronyms and Abbreviations}

\begin{tabular}{|c|c|}
\hline ANSI & American National Standards Institute \\
\hline ASTM & American Society for Testing and Materials \\
\hline $\mathrm{C} / \mathrm{C}_{0}$ & normalized concentration \\
\hline $\mathrm{CO}_{3}$ & carbonate \\
\hline ICP-MS & inductively coupled plasma mass spectrometry \\
\hline ICP-OES & inductively coupled plasma optical emission spectrometry \\
\hline LI & leachability index \\
\hline LSC & liquid scintillation counting \\
\hline $\mathrm{MC}$ & moisture content \\
\hline $\mathrm{NO}_{3}$ & nitrate \\
\hline $\mathrm{PVC}$ & polyvinyl chloride \\
\hline RNIP & reactive nanoscale zero-valent iron particles \\
\hline $\mathrm{SO}_{4}$ & sulfate \\
\hline STAR-CD & computational fluid dynamics code \\
\hline ZVI & zero-valent iron \\
\hline $1-\mathrm{D}$ & one-dimensional \\
\hline
\end{tabular}





\section{Contents}

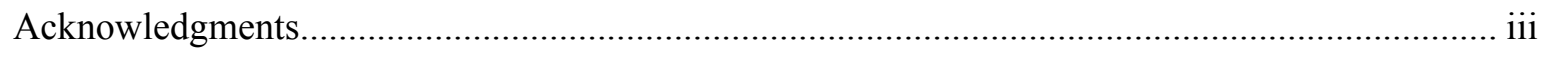

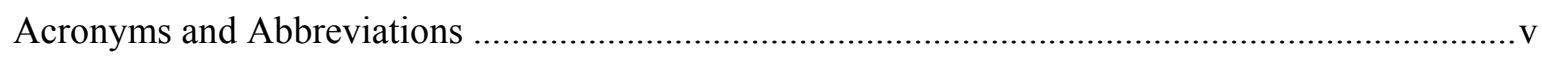

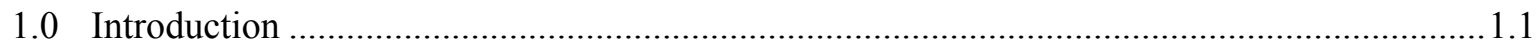

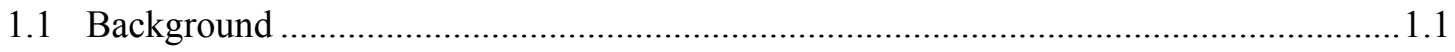

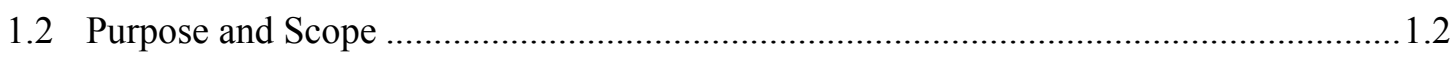

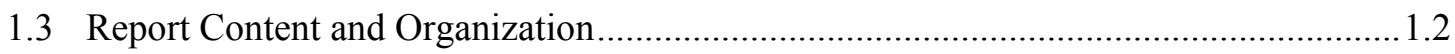

2.0 Concrete Composition and Fabrication of Test Specimens ...............................................2.1

2.1 Specified Concrete Composition for Encasement ........................................................2. 2.1

2.2 Materials and Laboratory-Scale Mixture Design .......................................................... 2.1

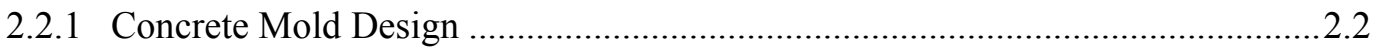

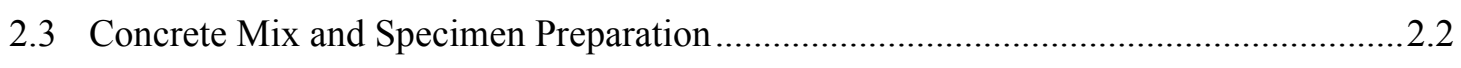

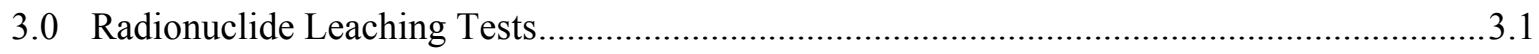

3.1 Effective Diffusivity Calculations ........................................................................ 3.1

3.2 Leaching of Technetium-99 and Iodine-125 from Concrete Specimens..........................3.3

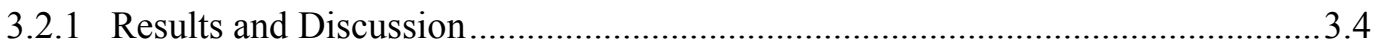

3.3 Effect of Iron on the Release of Rhenium, Iodine, and Technetium from Concrete......3.11

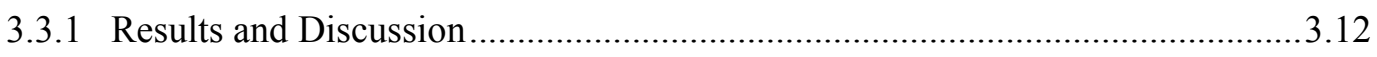

3.4 Summary of ANSI 16.1 Leaching Experiments.....................................................16

4.0 Characterization of Historic Concrete Samples and Supercritically Carbonated Concrete

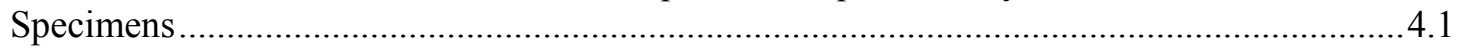

4.1 Carbonation Studies of Historic Concrete ...................................................................... 4.1

4.2 Supercritical Carbonation and Micro-Cracking of Concrete Specimens ........................ 4.2

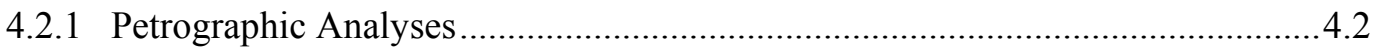

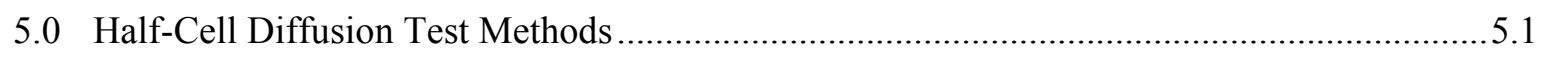

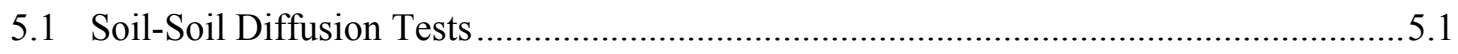

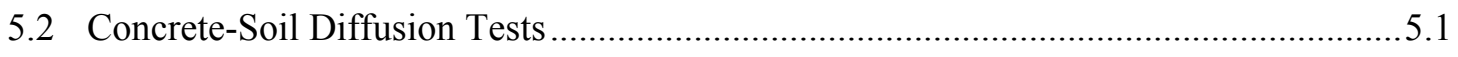

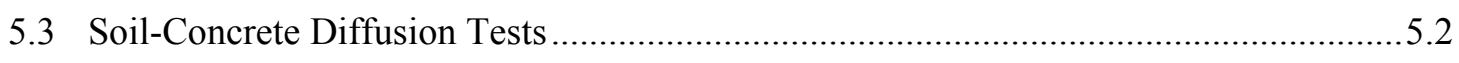

5.4 Diffusion Coefficient Calculations...............................................................................

6.0 Diffusion of Iodine and Technetium-99 in Soil-Soil and Concrete-Soil Half Cells ...............6.1

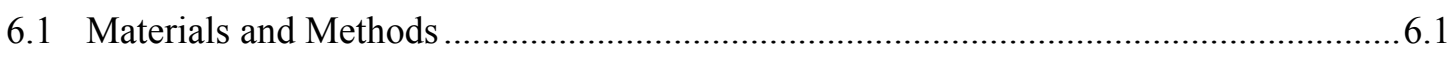

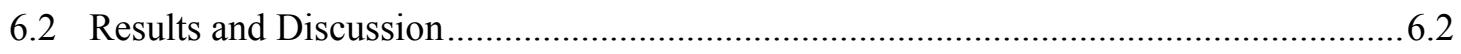

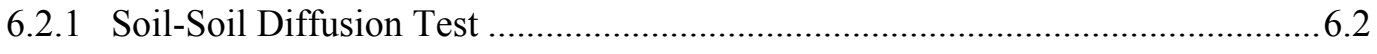

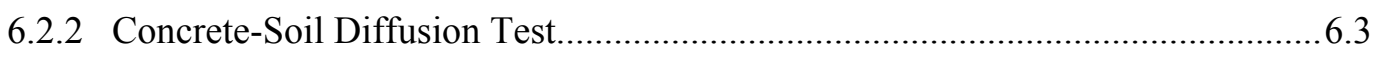

7.0 Effect of Supercritical Carbonation and Metallic Iron Addition on I and Re Diffusion in

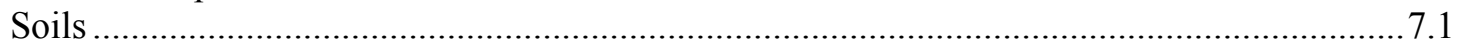

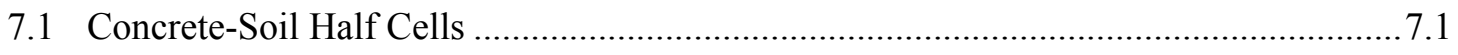

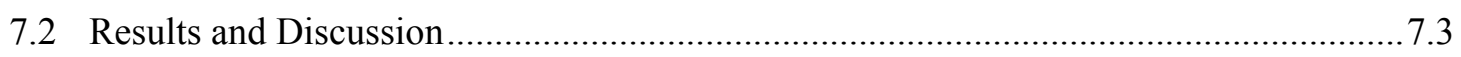


8.0 Concrete-Soil Half-Cell Experiments to Determine the Diffusion of Iodine and Rhenium

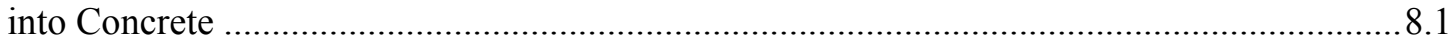

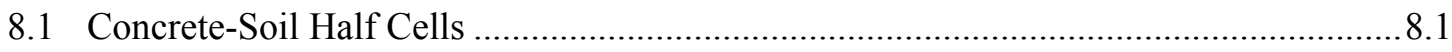

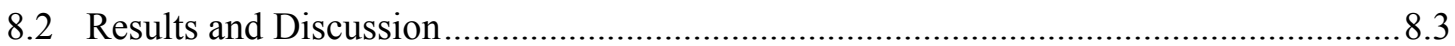

9.0 Effects of Carbonation and Metallic Iron on the Diffusion of Technetium and Iodine in Soils

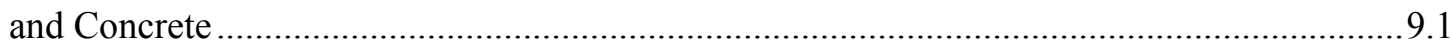

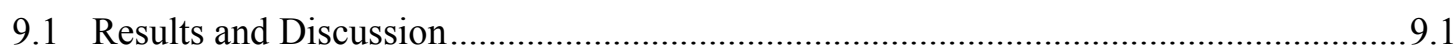

10.0 Diffusion of Iodine, Rhenium, and Technetium from Soil into Fractured Concrete .............10.1

11.0 Diffusion of Iodine, Rhenium, and Tc from Fractured Concrete into Soil...........................11.1

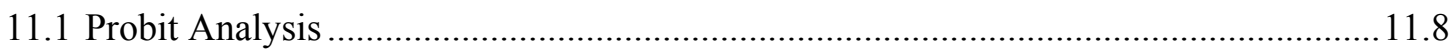

12.0 Modeling the Diffusion of Iodine and Technetium from a Reservoir Through a Concrete

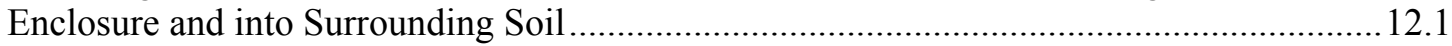

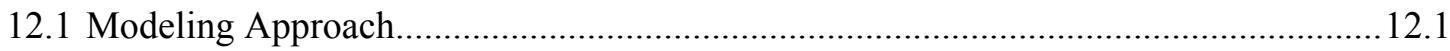

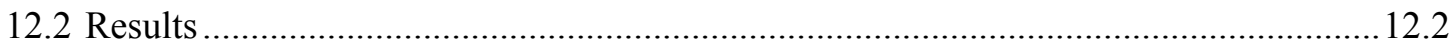

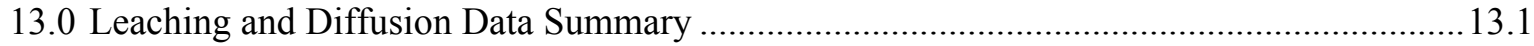

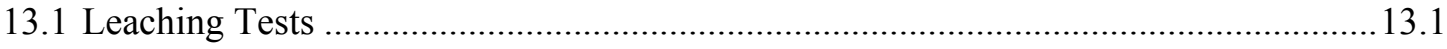

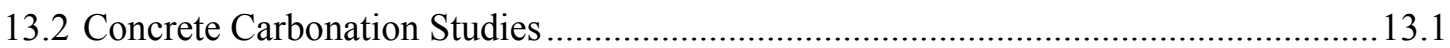

13.3 Diffusion of ${ }^{125} \mathrm{I}$ and ${ }^{99} \mathrm{Tc}$ in Soil-Soil and Concrete-Soil Half Cells ............................13.1

13.4 Effect of Solution Carbonation and Metallic Iron Addition on I and Tc Diffusion in

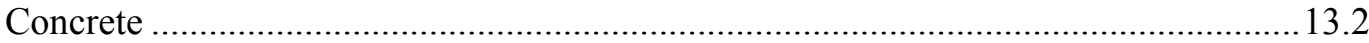

13.5 Diffusion of Iodine and Rhenium from Soil into Fractured Concrete............................13.2

13.6 Diffusion of Iodine and Rhenium from Fractured Concrete into Soil...........................13.3

13.7 Modeling Diffusion of Iodine and Technetium in Concrete and Soil ..........................13.3

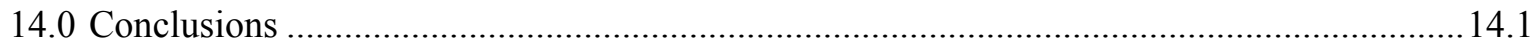

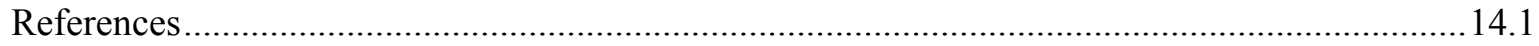




\section{Figures}

3.1 Dynamic leach test: cumulative leaching fraction as a function of time for iodine-125 .......... 3.6

3.2 Static leach test: cumulative leaching fraction as a function of time for iodine-125 ............... 3.6

3.3 Dynamic leach test: cumulative leaching fraction as a function of time for technetium-99 ..... 3.7

3.4 Static leach test: cumulative leaching fraction as a function of time for technetium-99.......... 3.7

3.5 Dynamic leach test: cumulative uranium adsorbed as a function of time ............................. 3.8

3.6 Static leach test: cumulative uranium adsorbed as a function of time................................... 3.8

3.7 Dynamic leach test: cumulative leaching fraction as a function of time for I, Re, and Tc....... 3.13

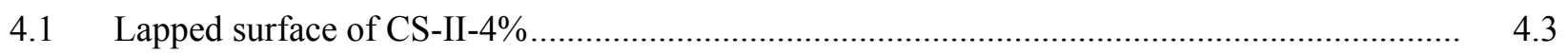

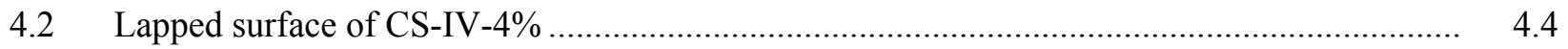

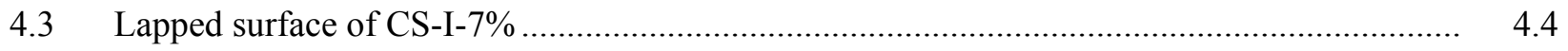

4.4 Lapped surface of CS-III-7\% ................................................................................ 4.5

5.1 Left: Mechanism for soil sampling from a diffusion half cell; Right: soil sampling from a

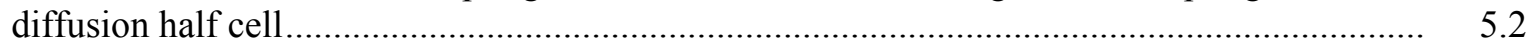

6.1 Normalized concentration profiles for iodide and ${ }^{99} \mathrm{Tc}$ in $7 \%$ water content soil-soil cells at

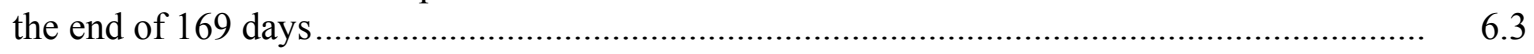

6.2 Probit plots for iodide and ${ }^{99} \mathrm{Tc}$ in $7 \%$ water content soil-soil cells at the end of 169 days ...... 6.3

6.3 Normalized concentration profiles for I and Tc in 7\% water concrete-soil cells at the end

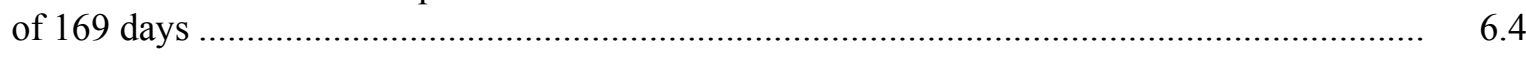

6.4 Probit plots for I and Tc in 7\% water content concrete-soil cells at the end of 169 days.......... 6.4

6.5 Calculated and measured concentration profiles for iodide in concrete-soil half cell .............. 6.4

6.6 Calculated and measured concentration profiles for ${ }^{99} \mathrm{Tc}$ in concrete-soil half cell ................ $\quad 6.5$

7.1 Concentration profiles of iodine and rhenium for soil half cells ..........................................

7.2 Concentration profiles of iodine and rhenium for soil half cells ......................................... 7.5

7.3 Probit plots for iodine and rhenium for soil half cells ........................................................

7.4 Probit plots for iodine and rhenium for soil half cells ..................................................... 7.7

8.1 I and Re concentration profiles for soil half cells at 4\%, 7\%, and $15 \%$ moisture content by weight in four types of concrete monoliths ....................................................................... 8.4

8.2 I and Re concentration profiles for concrete half cells at 4\%, moisture content by weight in

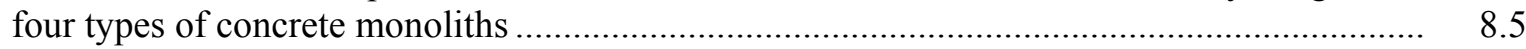

8.3 I and Re concentration profiles for concrete half cells at $7 \%$ and $15 \%$ moisture content by weight in four types of concrete monoliths. ......................................................................... 8.6

8.4 Probit plots for iodine and rhenium for concrete half cells ............................................. 8.7

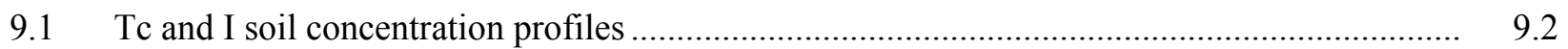

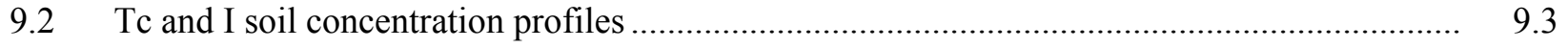

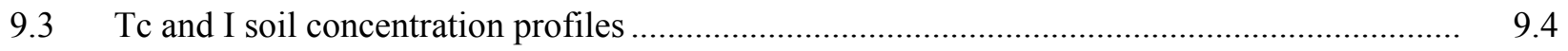

9.4 Concrete half-cell concentration profiles as a function of iron content.................................. 9.5

9.5 Concrete half-cell concentration profiles as a function of iron content................................... 9.6

9.6 Concrete half-cell concentration profiles as a function of iron content................................. 9.7 
9.7 Probit analysis for Tc in soil half cell: 4\% moisture content, no Fe, no carbonation ............... 9.8

9.8 Probit analysis for Tc in soil half cell: 4\% moisture content, $4 \% \mathrm{Fe}$, no carbonation............... 9.8

9.9 Probit analysis of Tc in concrete cores .......................................................................... 9.10

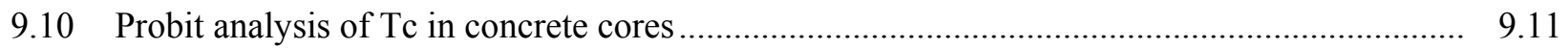

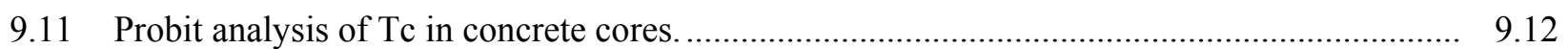

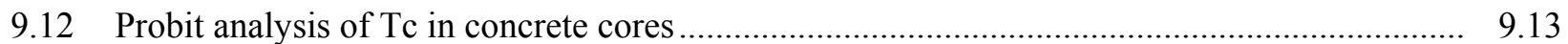

9.13 Probit analysis of $\mathrm{Tc}$ in concrete cores ......................................................................... 9.14

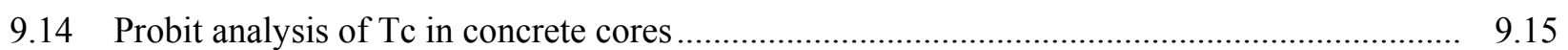

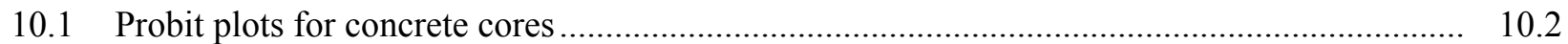

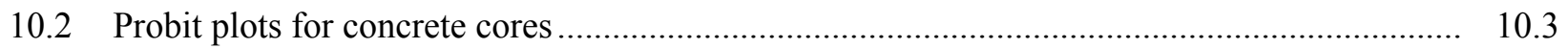

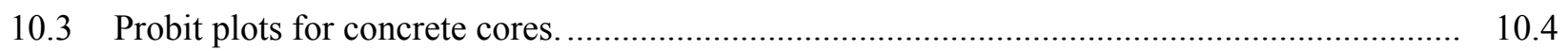

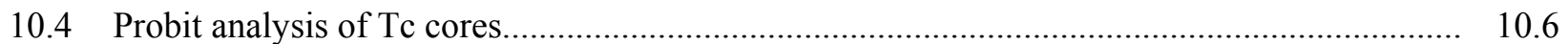

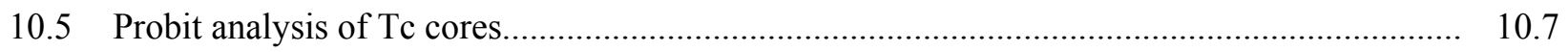

11.1 Concentration profiles for soil half-cell I and Re profiles ................................................. 11.2

11.2 Concentration profiles for soil half-cell I and Re profiles ..................................................... 11.3

11.3 Profiles for soil half-cell I and Re profiles ................................................................... 11.4

11.4 I and Re concrete half-cell concentration profile ............................................................ 11.5

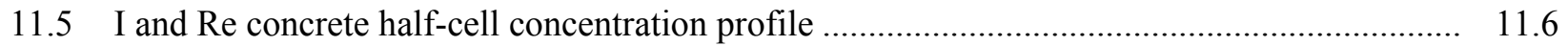

11.6 I and Re concrete half-cell concentration profile ...................................................... 11.7

11.7 Concentration profiles of Tc in soil cores in contact with spiked, carbonated, and non-

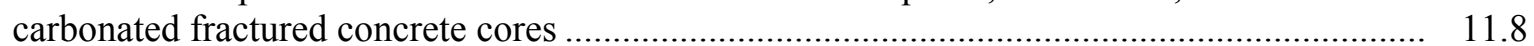

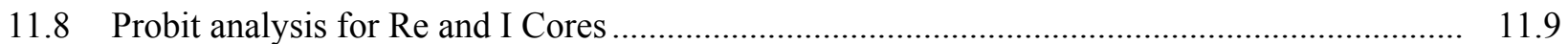

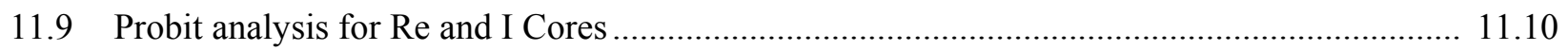

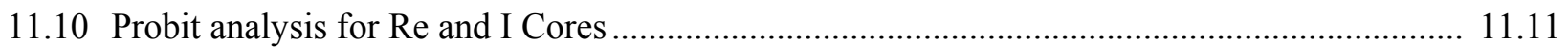

12.1 Plan-view schematic of the model domain where the rectangular concrete encasement wall is in contact with the surrounding soil region into which the species diffuse radially............ $\quad 12.2$

12.2 Iodine concentration profiles for the low diffusivity case .................................................. 12.4

12.3 Iodine concentration profiles for the high diffusivity case ................................................. 12.4

12.4 Technetium concentration profiles for the low diffusivity case ......................................... 12.5

12.5 Technetium concentration profiles for the high diffusivity case ....................................... 12.6 


\section{Tables}

$2.1 \quad$ Material Specifications and Composition......................................................................... 2.1

2.2 Laboratory-Scale Material Specification and Composition ................................................ 2.2

3.1 Characteristics of Cement Specimens Used in the Dynamic and Static Leach Tests............... 3.4

3.2 Composition of Hanford Site Groundwater Used in the Leaching Tests ............................... 3.4

3.3 Calculated effective diffusion coefficients and leaching indices for iodine-125 and technetium-99 from dynamic and static leach tests ...................................................... 3.10

3.4 Range of effective diffusion coefficients and leachability indices for the selected mix design and contaminant loading ............................................................................... 3.11

3.5 Characteristics of cement specimens used in dynamic leach tests .................................... 3.12

3.6 Composition of Hanford Site groundwater used in second experiment ................................ 3.12

3.7 Leach index data for Re and I as a functions of metallic iron-particle concentration .............. 3.14

3.8 Leach index data for Tc and I as a functions of RNIP particle concentration ........................ 3.15

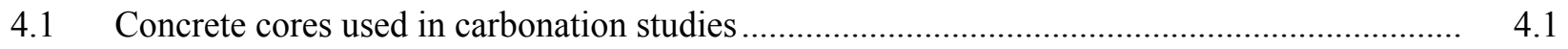

4.2 Characteristics of selected concrete cores from the Hanford Site .......................................... 4.1

4.3 Concrete monoliths subject to carbonation/micro-cracking analysis ................................... 4.2

4.4 Summary of petrographic observations for concrete half cells ............................................. 4.6

6.1 Characteristics of the Concrete-Soil and Soil-Soil Half Cells ................................................. 6.1

6.2 Calculated soil diffusion parameters for iodide and ${ }^{99} \mathrm{Tc}$ from soil-soil half-cell

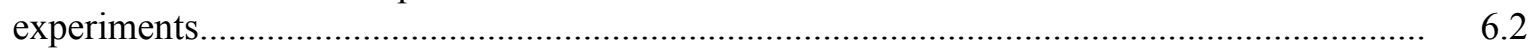

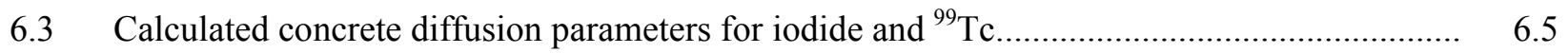

7.1 Characteristics of the concrete-soil half cells .................................................................... 7.2

7.2 Diffusivity of rhenium and iodine in soil in-soil half cells ..................................................

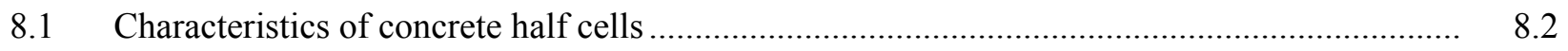

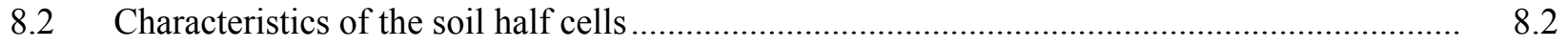

8.3 Diffusivity of rhenium and iodine in concrete half cells ..................................................... 8.8

9.1 Characteristics of concrete specimens used in concrete-soil half cells .................................. 9.1

9.2 Characteristics of cement specimens used in concrete-soil half-cell tests............................. 9.7

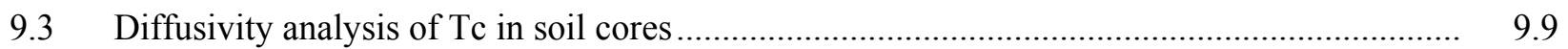

9.4 Diffusivity of Tc and I in concrete half cells ................................................................ 9.15

10.1. Characteristics of cement half cells used in fractured concrete-soil half-cell tests ................. 10.1

10.2 Characteristics of cement half cells used in fractured concrete-soil half-cell tests ................. 10.1

10.3 Diffusivity data for Re-I in fractured concrete half cells.................................................. 10.5

10.4 Diffusivity of Tc in fractured concrete cores............................................................ 10.7

11.1 Characteristics of concrete specimens used in concrete-soil half cells ................................ 11.1

11.2 Diffusivity analysis Re and I in soil half cells ............................................................... 11.12

12.1 Diffusivity values for concrete and soil used in the simulations ........................................ 12.1

12.2 Normalized concentration values for I and Tc at the concrete-soil interface ........................ 12.2

12.3 Depth of penetration I and Tc into soil as a function of time ............................................ 12.3 



\subsection{Introduction}

\subsection{Background}

One of the methods being considered for safely disposing of Category 3 low-level radioactive wastes is to encase the waste in concrete. Such concrete encasement would contain and isolate the waste packages from the hydrologic environment and would act as an intrusion barrier. The current plan for waste isolation consists of stacking low-level waste packages on a trench floor, surrounding the stacks with reinforced steel, and encasing these packages in concrete. These concrete-encased waste stacks are expected to vary in size with maximum dimensions of $6.4 \mathrm{~m}$ long, $2.7 \mathrm{~m}$ wide, and $4 \mathrm{~m}$ high. The waste stacks are expected to have a surrounding minimum thickness of $15 \mathrm{~cm}$ of concrete encasement. These concrete-encased waste packages are expected to withstand environmental exposure (solar radiation, temperature variations, and precipitation) until an interim soil cover or permanent closure cover is installed, and to remain largely intact thereafter.

Any failure of concrete encasement may result in water intrusion and consequent mobilization of radionuclides from the waste packages. The mobilized radionuclides may escape from the encased concrete by mass flow and/or diffusion and move into the surrounding subsurface environment. Therefore, it is necessary to assess the performance of the concrete encasement structure and the ability of the surrounding soil to retard radionuclide migration. The retardation factors for radionuclides contained in the waste packages can be determined from measurements of diffusion coefficients for these contaminants through concrete and fill material. Some of the mobilization scenarios include 1) potential leaching of waste form before permanent closure cover is installed; 2) after the cover installation, long-term diffusion of radionuclides from concrete waste form into surrounding fill material; 3) diffusion of radionuclides from contaminated soils into adjoining concrete encasement and clean fill material. Additionally, the rate of diffusion of radionuclides may be affected by the formation of structural cracks in concrete, the carbonation of the buried waste form, and any potential effect of metallic iron (in the form of rebars) on the mobility of radionuclides.

The radionuclides iodine-129 $\left({ }^{129} \mathrm{I}\right)$, technetium-99 $\left({ }^{99} \mathrm{Tc}\right)$, and uranium-238 $\left({ }^{238} \mathrm{U}\right)$ are identified as long-term dose contributors in Category 3 waste (Mann et al. 2001; Wood et al. 1995). Because of their anionic nature in aqueous solutions, ${ }^{129} \mathrm{I},{ }^{99} \mathrm{Tc}$, and carbonate-complexed ${ }^{238} \mathrm{U}$ may readily leach into the subsurface environment (Serne et al. 1989, 1992a, b, 1993, and 1995). The leachability and/or diffusion of radionuclide species must be measured to assess the long-term performance of waste grouts when contacted with vadose-zone pore water or groundwater.

Although significant research has been conducted on the design and performance of cementitious waste forms, the current protocol conducted to assess radionuclide stability within these waste forms has been limited to the Toxicity Characteristic Leaching Procedure, Method 1311 Federal Registry (EPA 1992) and ANSI/ANS-16.1 leach test (ANSI 1986). These tests evaluate the performance under watersaturated conditions and do not evaluate the performance of cementitious waste forms within the context of waste repositories which are located within water-deficient vadose zones. Moreover, these tests assess only the diffusion of radionuclides from concrete waste forms and neglect evaluating the mechanisms of retention, stability of the waste form, and formation of secondary phases during weathering, which may serve as long-term secondary hosts for immobilization of radionuclides. 
The results of recent investigations conducted under arid and semi-arid conditions (Al-Khayat et al. 2002; Garrabrants et al. 2002; Garrabrants and Kosson 2003; Garrabrants et al. 2004; Gervais et al. 2004; Sanchez et al. 2002; Sanchez et al. 2003) provide valuable information suggesting structural and chemical changes to concrete waste forms which may affect contaminant containment and waste form performance. However, continued research is necessitated by the need to understand: the mechanism of contaminant release; the significance of contaminant release pathways; how waste form performance is affected by the full range of environmental conditions within the disposal facility; the process of waste form aging under conditions that are representative of processes occurring in response to changing environmental conditions within the disposal facility; the effect of waste form aging on chemical, physical, and radiological properties, and the associated impact on contaminant release. Recent reviews conducted by the National Academies of Science recognized the efficacy of cementitious materials for waste isolation, but further noted the significant shortcomings in our current understanding and testing protocol for evaluating the performance of various formulations.

\subsection{Purpose and Scope}

During the project lifetime, the diffusion of radionuclides has been quantified from concrete into soil and from spiked soil into concrete as a function of the following environmental and concrete waste form parameters:

- radionuclide concentration

- diffusion time

- carbonation of concrete waste forms

- experimental methods of carbonation

- concrete waste form micro-cracking

- fracturing of concrete waste forms

- iron content in concrete waste forms

- soil moisture content.

A summary report that includes a compilation of all diffusion data analysis, will provide a basis to predict diffusivity of I and Tc into and out of waste forms and the encasing vadose zone soils. In addition, the results of the probit analyses and quantification of diffusion coefficients (see below) will be utilized to calculate the diffusion of I, Re, and Tc through 6 inches of concrete.

\subsection{Report Content and Organization}

The composition of concrete used in all the tests, and the fabrication of specimens are described in Section 2.0. Section 3.0 includes the results of dynamic (ANSI 16.1) and static leach tests conducted on concrete specimens containing ${ }^{125} \mathrm{I},{ }^{99} \mathrm{Tc}$ and $\mathrm{U}$ spikes with and without metallic iron $(40-60 \mathrm{mesh}$ and nanoscale zero valent iron ZVI). The carbonation data on historic concrete cores from Hanford Site and effects of supercritical carbonation on concrete specimens are provided in Section 4.0. The experimental set up used for all the half-cell diffusion tests and the data analysis method is described in Section 5.0. 
In Section 6.0, results of the initial set of soil-soil and concrete-soil half cell diffusion tests for ${ }^{125} \mathrm{I}$ and, ${ }^{99} \mathrm{Tc}$ are presented. Section 7.0 includes the results of half cell tests conducted to examine the effects of supercritical carbonation and inclusion of metallic iron in concrete half cells on diffusion of iodide and rhenium into soil half cells. Section 8.0 describes the effect of supercritical carbonation and the addition of metallic iron on the diffusivity of Re and I in concrete half cells. Section 9.0 includes the results of tests conducted to examine the effects of solution immersion carbonation and inclusion of various quantities of metallic iron on diffusion of Tc and I in soil and concrete half cells. The results of tests conducted to determine the diffusivities of Tc, Re, and I into fractured concrete are described in Section 10.0. Similarly, the results of tests conducted to study the diffusion of these elements into soils from fractured concrete are included in Section 11.0.

Section 12.0 includes the results of time-dependent modeling of the diffusion of Tc and I through 6 inches of concrete encasement into surrounding soils, and Section 13.0 summarizes the results of all the tests. References are listed in Section 14.0. 



\subsection{Concrete Composition and Fabrication of Test Specimens}

The concrete composition for the burial encasement was indicated in Specification for Concrete Encasement for Contact-Handled Category 3 Waste. This specification was used as the basis to prepare a concrete for fabrication of test specimens.

\subsection{Specified Concrete Composition for Encasement}

The specified composition includes sulfate-resistant Portland Type I or Type II cement, a pozzolanic material (Class F fly ash), fine and coarse aggregates, and steel fiber. Additional specifications include a water-to-cement ratio of 0.4 and an air content $6.0 \pm 1.5 \%$. The nominal proportions and material specifications based on this initial design are listed in Table 2.1

Table 2.1. Material Specifications and Composition

\begin{tabular}{|c|c|c|c|}
\hline Material & Specifications & $\begin{array}{l}\text { Specified } \\
\text { Field Mix }\end{array}$ & $\begin{array}{c}\text { Normalized } \\
\text { Specification } \\
\text { Design }\end{array}$ \\
\hline Cement & Portland Type I or Type I/II sulfate-resistant cement & $381 \mathrm{~kg} / \mathrm{m}^{3}$ & 0.27 \\
\hline Fly Ash & Class F fly ash; nominal $15 \%$ of cement by vol. & $54 \mathrm{~kg} / \mathrm{m}^{3}$ & 0.04 \\
\hline Coarse Aggregate & No. 676 or equivalent (3/4" nominal size) & $55 \%$ by vol. & 0.04 \\
\hline Fine Aggregate & Sand & $45 \%$ by vol. & 0.51 \\
\hline Water & Nominal water-to-cement ratio: 0.4 & $399 \mathrm{~kg} / \mathrm{m}^{3}$ & 0.10 \\
\hline Steel Fiber & Deformed Type I, nominal length $2.5-3.8 \mathrm{~cm}(1-1.5 ")$ & $59 \mathrm{~kg} / \mathrm{m}^{3}$ & 0.04 \\
\hline Air Content & -- & $6.0 \pm 1.5 \%$ & -- \\
\hline
\end{tabular}

\subsection{Materials and Laboratory-Scale Mixture Design}

A laboratory-scale concrete mixture (Table 2.2) was prepared based on specifications shown in Table 2.1. Because of the required small dimensions of laboratory test specimens, the size of the coarse aggregate and the dimensions of the steel fiber specified in Table 2.1 were proportionately reduced. This was accomplished by decreasing the $2-\mathrm{cm}(\sim 0.75 \mathrm{in}$.) coarse aggregate size in the original specification to a particle size ranging from $2.83 \mathrm{~mm}$ to $2 \mathrm{~mm}$ in the laboratory mix. The aggregate mixture passing a 7mesh sieve and retained on a 10-mesh sieve met this particle size specification. The scaled-down steel fibers used in the laboratory mix consisted of Bekaert Dramix brand deformed steel wire fibers that were cut to a nominal length of $8 \mathrm{~mm}(0.31 \mathrm{in})$. The deformed end portions were retained for use in the concrete mixture and the straight middle section of the fiber was discarded. Based on these modifications, a concrete mix was prepared that consisted of Portland Cement (Type I \& II, ASTM C-150 compliant), Class F fly ash, scaled-down coarse aggregate, fine aggregate, scaled-down deformed steel fiber, and a water-entraining agent (PolyHeed $(997)$. The water-entraining agent was included in the mix to facilitate the workability of the concrete. The volumes of the PolyHeed ${ }^{\circledR} 997$ and the air-entraining agent, MBАE ${ }^{\text {TM }}$ 90, were not included in the normalization calculations because of their negligible contribution to the overall mix volume. The material specification and composition for the laboratory-scale concrete mixture is given in Table 2.2. 
Table 2.2. Laboratory-Scale Material Specification and Composition

\begin{tabular}{|c|c|c|c|}
\hline Material & $\begin{array}{l}\text { Material Specifications } \\
\text { for Field Mix }\end{array}$ & $\begin{array}{c}\text { Normalized } \\
\text { Laboratory Design }\end{array}$ & $\begin{array}{c}\text { Material Specifications Used in } \\
\text { Revised Laboratory Mix Comparison }\end{array}$ \\
\hline Cement & $\begin{array}{l}\text { Portland Type I or Type I/II sulfate- } \\
\text { resistant cement }\end{array}$ & 0.27 & Portland Type I \& II \\
\hline Fly Ash & $\begin{array}{l}\text { Class F fly ash; nominal 15\% of } \\
\text { cement by volume }\end{array}$ & 0.04 & $\begin{array}{l}\text { Class F fly ash; nominal } 20 \% \text { of } \\
\text { cement by volume }\end{array}$ \\
\hline $\begin{array}{l}\text { Coarse } \\
\text { Aggregate }\end{array}$ & $\begin{array}{l}\text { No. } 676 \text { or equivalent ( } 3 / 4 \text { " nominal } \\
\text { size) }\end{array}$ & 0.04 & $\begin{array}{l}\text { Sieve size }+7 \text { to }-10 \\
(2.83-2 \mathrm{~mm} \text { size })\end{array}$ \\
\hline Fine Aggregate & Sand & 0.51 & Sand -10 sieve size $(<2 \mathrm{~mm})$ \\
\hline Water & Nominal water-to-cement ratio: 0.4 & 0.10 & Water-to-cement ratio: 0.5 \\
\hline Steel Fiber & $\begin{array}{l}\text { Deformed Type I, nominal length } \\
2.5-3.8 \mathrm{~cm}(1-1.5 ”)\end{array}$ & 0.04 & $\begin{array}{l}\text { Deformed, nominal length } 8 \mathrm{~mm} \\
\text { (0.32 in) }\end{array}$ \\
\hline PolyHeed® 997 & -- & 0.00375 & Water-entraining agent \\
\hline Air Content & $6.0 \pm 1.5 \%$ & $6.0 \pm 1.5 \%$ & -- \\
\hline
\end{tabular}

\subsubsection{Concrete Mold Design}

The concrete molds for casting specimens were fabricated from Schedule 40 polyvinyl chloride (PVC) piping material. Gaskets were glued to the bottom of the molds and leak tested before use. The PVC forms were pre-treated with form release, a liquid that allows the concrete specimen to release easily from the mold. The first treatment was applied 3 days prior, and the second treatment was applied a few hours before wet concrete was added to the molds.

\subsection{Concrete Mix and Specimen Preparation}

Concrete monoliths were prepared with mix components added in this order: water, steel (if applicable), coarse aggregate, fine aggregate, fly ash, cement, PolyHeed ${ }^{\circledR} 997$, and MB-AE ${ }^{\text {TM }} 90$. The concrete was mixed on medium speed using a Hobart 3-speed bench top mixer in a $4 \mathrm{~L}$ steel bowl. The PVC molds were filled in the vertical positions. After filling, the molds were lightly tapped on the laboratory bench until a significant decrease in the release of air bubbles was observed. The forms were stored in plastic bags with damp paper towels to provide moisture while the concrete set. 


\subsection{Radionuclide Leaching Tests}

The dynamic leach test is an American National Standards Institute (ANSI)-16.1 standard test that is designed to examine the leaching rate of contaminants in concrete and grout specimens to determine the cumulative fractions leached and effective diffusion coefficients. This test is conducted according to protocol specified by ANSI (1986).

There are two types of leach tests (dynamic and static) available to assess the leachability of constituents of interest from the concrete specimens. The ANSI 16.1 leach test is a regulatory test that requires leaching the test specimens; at the end of a defined period all the solution is replaced with fresh deionized distilled water. This dynamic test maintains an aggressive leaching regime in that a high chemical potential difference of a contaminant is created between a concrete specimen and the leach solution. In comparison, the non-regulatory static test, is much less aggressive in that only a small portion of the leaching solution is renewed periodically to monitor the radionuclide activities in solution. Therefore, in a static test the chemical potential difference of a contaminant will decrease as a function of time.

\subsection{Effective Diffusivity Calculations}

Based on a number of leach studies, Serne et al. (1992a, 1995) concluded that leaching from a semiinfinite solid source would be the most appropriate model to describe the release of trace contaminants from grout and cement specimens. Seven critical assumptions in their model were:

- The concentration of leaching contaminant species at the surface of the specimen is always zero; i.e., the contaminant is instantaneously removed by the liquid as soon as the species diffusing from the solid reaches the solid-liquid interface.

- The composition of the liquid in contact with the solid being leached is constant. This implies that the leaching contaminant will not significantly change the liquid composition.

- The solid waste form does not alter physically or chemically during the leaching process. A critical part of this assumption is that the mass of constituents leached is insignificant when compared to the total mass of these constituents in the solid, thus fulfilling the semi-infinite solid requirement.

- The surface area of the solid is constant and does not change by armoring (i.e., formation of a protective layer during leaching).

- Any chemical reaction is rapid enough so that chemical equilibrium always exists between leaching species in the solid and the liquid.

- Each contaminant exists as a single chemical species such as all free, cationic, anionic, or neutral species, or in a complexed form (either a single cationic, anionic, or neutral species).

- Bulk diffusion is the rate-limiting process for contaminant leaching.

Leaching of semi-infinite solids has been described mathematically using either incremental leach rates or cumulative leach rates (Serne et al. 1992a, b; 1995). Using incremental leach rates, the effective diffusion coefficient for each leach interval $\left(D_{\mathrm{ei}}\right)$ for a species of interest is expressed as: 


$$
D_{e i}=\pi\left[\left(\frac{a_{n}}{A_{o}}\right) / \Delta t_{n}\right]^{2}\left[\frac{V}{S}\right]^{2}[T]
$$

Using cumulative leaching rates, the effective diffusion coefficient $\left(D_{e c}\right)$ is expressed as:

$$
D_{e c}=\pi / 4\left[\left(\frac{\Sigma a_{n}}{A_{o}}\right) / \Delta t_{n}\right]^{2}\left[\frac{V}{S}\right]^{2}\left[\frac{1}{t}\right]
$$

where $\quad D_{e i}=$ effective diffusivity coefficient $\left(\mathrm{cm}^{2} / \mathrm{s}\right)$ for the leaching interval, $\mathrm{t}_{\mathrm{n}}-\mathrm{t}_{\mathrm{n}-1}$

$D_{e c}=$ effective diffusivity coefficient $\left(\mathrm{cm}^{2} / \mathrm{s}\right)$ for the cumulative leach interval, $\mathrm{t}_{\mathrm{n}}-\mathrm{t}_{\mathrm{o}}$

$a_{n}=$ activity of radionuclide leached during the leaching interval, $\mathrm{t}_{\mathrm{n}}-\mathrm{t}_{\mathrm{n}-1}$

$\Sigma a_{n}=$ total activity of radionuclide cumulatively leached during the interval, $\mathrm{t}_{\mathrm{n}}-\mathrm{t}_{\mathrm{o}}$

$A_{o}=$ total initial activity of radionuclide in the specimen

$a_{n} / A_{o}=$ fraction of radionuclide leached during interval, $\mathrm{t}_{\mathrm{n}}-\mathrm{t}_{\mathrm{n}-1}$

$\frac{\Sigma a_{n}}{A_{o}}=$ cumulative fraction of radionuclide leached during the interval $\mathrm{t}_{\mathrm{n}}-\mathrm{t}_{\mathrm{o}}$

$\Delta \mathrm{t}_{\mathrm{n}}=$ duration of the nth leaching interval, $\mathrm{t}_{\mathrm{n}}-\mathrm{t}_{\mathrm{n}-1}$ in seconds

$V=$ volume of the specimen, $\mathrm{cm}^{3}$

$S=$ geometric surface area of the specimen, $\mathrm{cm}^{2}$

$T=$ mean leaching time $=\left[\frac{1}{2\left(\sqrt{t_{n}}+\sqrt{t_{n-1}}\right)}\right]^{2}$

$t=$ total elapsed time from leaching initiation in seconds.

According to Serne et al. (1992a, b; 1995), if the leach experiments satisfy all the seven conditions listed above for semi-infinite solids, both equations 3.1 and 3.2 would provide the same effective diffusion coefficient for all times. However, in actual leaching experiments, many of the conditions cannot be met; therefore, the calculated average $D_{e i}$ and $D_{e c}$ are different. For instance, Serne et al. (1992a, b; 1995) observed that armoring is a common phenomenon in leach studies of cement specimens, which would affect the leach rates depending on the rate of formation, thickness, and the chemical nature of surface armoring. Additionally, certain species may leach out in sufficient quantities, which would invalidate the third assumption of insignificant leach fraction. Also, a number of chemical speciation studies have indicated that in cement specimens, each leaching species does not exist as a single chemical species. Therefore, the assumption of single diffusing chemical species may not be valid.

In leaching experiments where the leaching fraction of a species is significant ( $>20 \%$ the amount contained initially in a specimen), the ANSI protocol recommends a specimen shape-specific solution of the mass transport equation. The effective diffusion coefficient in this case for a cylindrical specimen is calculated by using the equation: 


$$
D_{e c}=\frac{G d^{2}}{t}
$$

where $\quad G=$ a dimensionless time factor for the cylinder

$d=$ the diameter of the cylinder in $\mathrm{cm}$

$t=$ total elapsed time from leaching initiation in seconds.

The average effective diffusion coefficients were calculated from the values determined for each leaching interval $\left(D_{e i}\right)$ and each cumulative leach time $\left(D_{e c}\right)$. The leachability index for each radionuclide was calculated from the average effective diffusion coefficient values as:

$$
\mathrm{LI}=\log \left(\beta / D_{e}\right)
$$

where $\quad L I=$ leachability index

$\beta=$ a constant $=1 \mathrm{~cm}^{2} / \mathrm{s}$

$D_{e}=$ average effective diffusion coefficient.

\subsection{Leaching of Technetium-99 and Iodine-125 from Concrete Specimens}

The dynamic (ANSI 16.1) leach tests were conducted according to protocol specified by ANSI (1986). These leach tests were conducted on specimens of intact concrete cylinders of $\sim 2 \mathrm{~cm}$ in diameter and $4 \mathrm{~cm}$ length. The characteristics of the specimens used are listed in Table 3.1. The test protocol was slightly modified in that actual groundwater from the Hanford Site was used as the leachant instead of ANSI 16.1 specified demineralized water. In all tests, the ratio of leachant volume to the surface area of test specimens was held constant at $\sim 10 \mathrm{~cm}\left(350 \mathrm{~cm}^{3} / 35 \mathrm{~cm}^{2}\right)$. The composition of Hanford groundwater is listed in Table 3.2. In leachates, the activities of iodine-125 and technetium-99 were measured with liquid scintillation counting (LSC). Additionally, the concentrations of technetium-99 and uranium in leachates of selected leach experiments were measured using inductively coupled plasma mass spectrometry (ICP-MS). From the data, cumulative leached fraction, the effective diffusion coefficient, and the leachability index for each contaminant were calculated.

The static leach test was designed to determine the diffusion coefficient under conditions of decreasing chemical potential between solid and solution phases. As discussed previously, the static leach test differs from the dynamic leach test because the chemical potentials of leaching constituents between the solid and the solution phases in the static test is maintained at a near-constant level by periodically renewing the solution phase. The static leach tests were conducted on specimens of intact concrete cylinders $\sim 2 \mathrm{~cm}$ in diameter and $\sim 4 \mathrm{~cm}$ in length. The leachant consisted of Hanford Site groundwater. At prescribed times, $50 \mathrm{ml}$ of leachate was removed for analysis, and $50 \mathrm{ml}$ of fresh groundwater was added to the containers to maintain the total volume of the leach solution at $\sim 350 \mathrm{ml}$. 
Table 3.1. Characteristics of Cement Specimens Used in the Dynamic and Static Leach Tests

\begin{tabular}{ccccc}
\hline $\begin{array}{c}\text { Specimen } \\
\text { No. }\end{array}$ & $\begin{array}{c}\text { Length } \\
(\mathrm{cm})\end{array}$ & $\begin{array}{c}\text { Diameter } \\
(\mathrm{cm})\end{array}$ & $\begin{array}{c}\text { Surface Area } \\
\left(\mathrm{cm}^{2}\right)\end{array}$ & $\begin{array}{c}\text { Volume } \\
\left(\mathrm{cm}^{3}\right)\end{array}$ \\
\hline 1 & 4.20 & 2.10 & 34.64 & 14.55 \\
2 & 4.10 & 2.10 & 33.98 & 14.20 \\
3 & 4.10 & 2.10 & 33.98 & 14.20 \\
5 & 4.30 & 2.10 & 35.30 & 14.89 \\
6 & 4.50 & 2.10 & 36.62 & 15.59 \\
7 & 4.20 & 2.10 & 34.64 & 14.55 \\
8 & 4.30 & 2.10 & 35.30 & 14.89 \\
9 & 4.20 & 2.10 & 34.64 & 14.55 \\
\hline
\end{tabular}

Table 3.2. Composition of Hanford Site Groundwater Used in the Leaching Tests

\begin{tabular}{cccc}
\hline Constituent & $\begin{array}{c}\text { Concentration } \\
(\mathrm{mg} / \mathrm{L})\end{array}$ & Constituent & $\begin{array}{c}\text { Concentration } \\
(\mathrm{mg} / \mathrm{L})\end{array}$ \\
\hline $\mathrm{Al}$ & 0.14 & $\mathrm{Si}$ & 16.2 \\
$\mathrm{~B}$ & 0.05 & $\mathrm{Sr}$ & 0.28 \\
$\mathrm{Ba}$ & 0.069 & $\mathrm{U}$ & 0.0067 \\
$\mathrm{Ca}$ & 67.5 & $\mathrm{Cl}$ & 22.0 \\
$\mathrm{Fe}$ & 3.0 & $\mathrm{NO}_{3}$ & 1.7 \\
$\mathrm{~K}$ & 3.0 & $\mathrm{SO}_{4}$ & 108.0 \\
$\mathrm{Mg}$ & 16.4 & Tot $\mathrm{Alk}\left(\mathrm{as} \mathrm{CO}_{3}\right)$ & 67.5 \\
$\mathrm{Mn}$ & 0.046 & $\mathrm{TOC}$ & 0.73 \\
$\mathrm{Na}$ & 27.6 & $\mathrm{pH}$ & $8.46(\mathrm{SU})$ \\
\hline
\end{tabular}

$\mathrm{TOC}=$ total organic carbon

$\mathrm{SU}=$ standard units

The $50 \mathrm{ml}$ aliquots were filtered through a $0.45 \mu \mathrm{m}$ membrane and analyzed for activities of iodine125 and technetium-99 using liquid scintillation. Additionally, the concentrations of technetium-99, and uranium in leachates of selected leach experiments were measured using ICP-MS. The cumulative leached fraction, the effective diffusion coefficient, and the leaching index for each contaminant were calculated from the data.

\subsubsection{Results and Discussion}

The leaching data from both dynamic and static tests are plotted as cumulative leach fractions or cumulative adsorbed $\left(\mathrm{ng} / \mathrm{cm}^{2}\right)$ as a function of leaching time (Figures 3.1 through 3.6). The calculated effective diffusion coefficients are listed in Tables 3.3 and 3.4.

\subsubsection{Leaching Characteristics}

The results showed that in the dynamic leach test, iodine-125 leaches rapidly during the first five days. Iodine continues to leach at an attenuated rate for the remainder of the experiment. All four specimens showed differing leaching rates. . One explanation for these small differences in leaching may 
be due to the type of iodine redox species that exist in these specimens. For instance, the steel fibers in specimens 6 and 7 may reduce iodine species through oxidation and this reduced species may have a lower rate of diffusion than the oxidized species. For example, if the original iodine spike was in the form of iodate ions $\left(\mathrm{IO}_{3}^{-}\right)$, the reduction of this species coupled by oxidation of metallic iron would result in the formation of iodide ions $\left(\mathrm{I}^{-}\right)$. This redox reaction may be represented by:

$$
\mathrm{IO}_{3}^{-}+3 \mathrm{Fe}^{0}+3 \mathrm{H}_{2} \mathrm{O}=\mathrm{I}^{-}+3 \mathrm{Fe}^{2+}+6 \mathrm{OH}^{-}
$$

Therefore, if the original spike is in the form of iodate, the differing diffusion behavior of iodate and iodide species may be reflected in the observed differences in the leach rates. However, there is no data at present to confirm either the initial redox state of the iodine spike or the chemical species of iodine in the leachate.

The results from the static leach test (Figure 3.2) indicated that, in general, the leaching tendency of iodine was similar to what was observed in dynamic leach tests except that the overall cumulative leach fractions were on average lower than that of dynamic leach tests. Also, one of the specimens (specimen 3) cumulatively leached about four times more iodine than the other three specimens. Because all the specimens were prepared at the same time, the anomalous leaching of iodine from specimen 3 may be due to the more porous nature of this specimen. Also, when compared to the results of the dynamic leach test, there was no difference in iodine leachability between specimens with and without steel fibers.

The cumulative leaching data for technetium-99 is included in Figures 3.3 and 3.4. As a check the leach fractions were calculated using both LSC activity data and the mass measured by using ICP-MS. The cumulative leach fractions calculated by both these methods agreed well in all cases except for specimen 1. For this specimen, the LSC data consistently indicated about $20 \%$ higher leaching than the data obtained from the ICP-MS measurements. The dynamic leach test indicated that technetium-99 in these specimens had a greater leaching tendency than iodine-125. In these tests, technetium-99 appeared to leach rapidly during the first five days and leached at a significantly reduced rate for the remaining period. The leaching behavior of technetium-99 is similar to the leaching pattern of iodine- 125 observed from the same cement specimens. There were no significant differences in cumulative leach fractions of technetium-99 between specimens with or without the addition of steel fibers, indicating that steel fibers did not cause any significant changes in the species of $\mathrm{Tc}$ as indicated by the redox reaction:

$$
2 \mathrm{TcO}_{4}^{-}+3 \mathrm{Fe}^{0}+4 \mathrm{H}^{+}=3 \mathrm{Fe}^{2+}+2 \mathrm{TcO}_{2}+4 \mathrm{OH}^{-}
$$

The leaching data from the static tests also indicated that technetium-99 leaches to a greater degree than iodine-125 from the same set of specimens. As compared to all other specimens, specimen 3 which leached anomalously high fractions of iodine-125, also leached significantly higher fractions (about 5 times) of technetium-99. Such leaching behavior suggested that specimen 3, due to some unknown reason, had distinctly different physical characteristics than other specimens, most likely micro-cracks that promoted a significantly higher rate of leaching for these two radionuclides.

Measured concentrations in both dynamic and static leach tests indicated that none of the specimens leached uranium (Figures 3.5 and 3.6). In fact, the concrete specimens adsorbed uranium from the Hanford Site groundwater used in these experiments, which initially contained approximately $6.7 \mathrm{ppb}$ (Table 3.2). Even though the total mass of uranium in each specimen exceeded the mass of uranium in contacting groundwater by more than two orders of magnitude, no uranium leaching was observed from any of the specimens. Therefore, these data indicated that the spiked uranium in the specimens was in a 
nonleachable, recalcitrant solid form, and that the cement matrix had a strong affinity to adsorb and immobilize additional uranium from solution. Such uranium adsorption from groundwater by cement specimens has been observed previously by Serne et al. (1989). Overall, the cement specimens in the static tests on average adsorbed 50\% more uranium than specimens in the dynamic tests. The higher adsorption observed in the static tests can be explained on the basis of continual long contact of leach solutions (with fractional solution exchange) with the specimens. Comparatively, in the dynamic leach tests, the leach solutions are renewed frequently; therefore, the specimens are in contact with leach solution for shorter periods of time. The leach test $\mathrm{pH}$ also would likely affect the amount of uranium adsorbed. Uranium adsorption increases with $\mathrm{pH}$ and in static leach tests, the $\mathrm{pH}$ conditions are higher than in dynamic tests.

ANSI Leach Test (I-125)

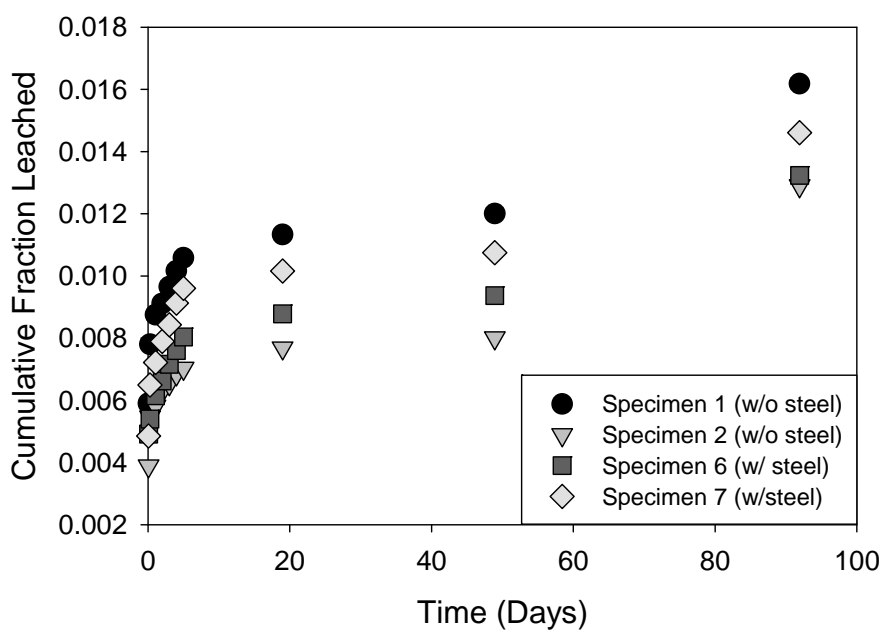

Figure 3.1. Dynamic leach test: cumulative leaching fraction as a function of time for iodine- 125

ANSI Leach Test (I-125)

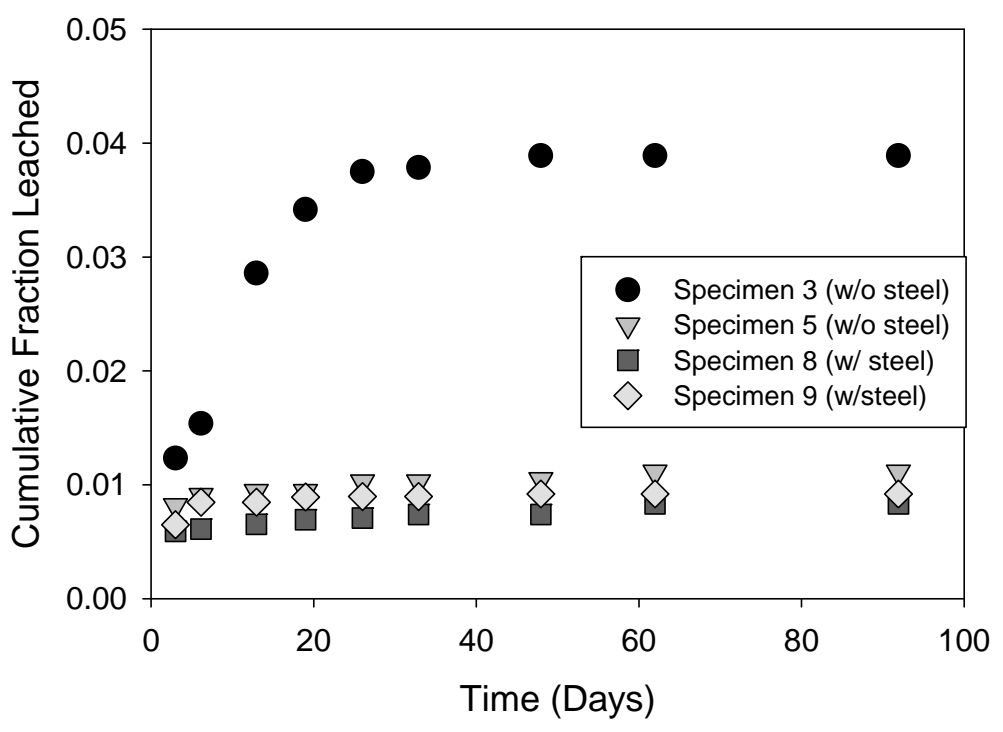

Figure 3.2. Static leach test: cumulative leaching fraction as a function of time for iodine- 125 


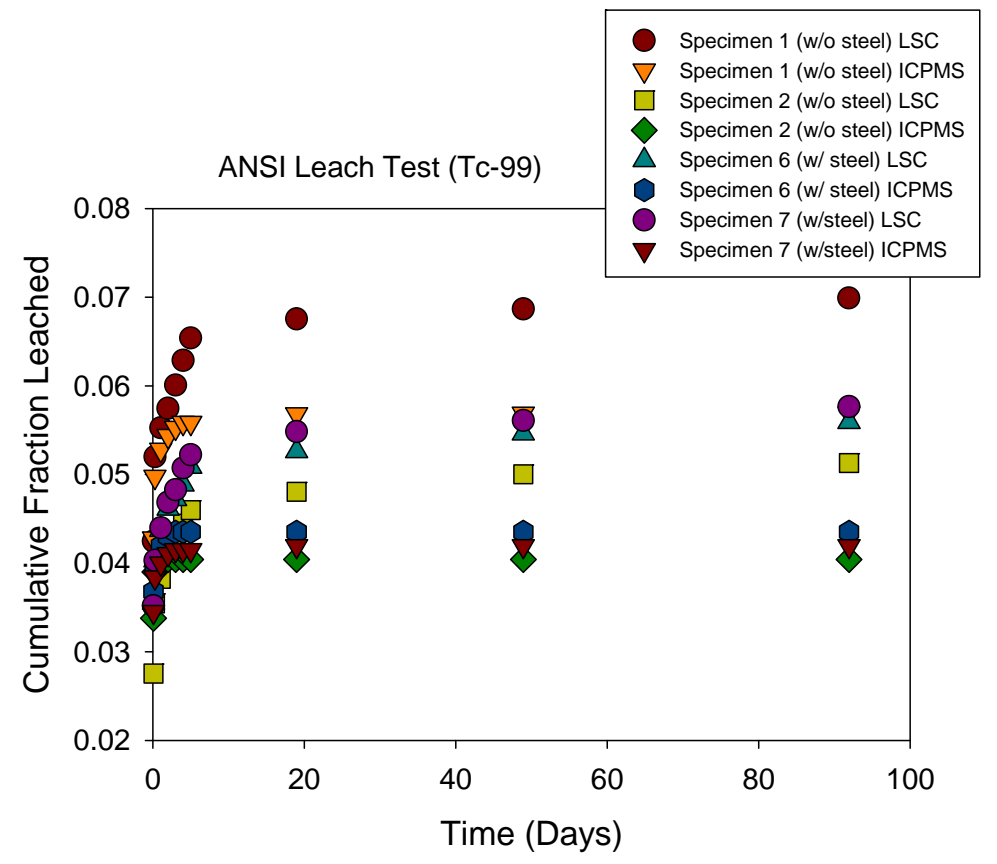

Figure 3.3. Dynamic leach test: cumulative leaching fraction as a function of time for technetium-99 ANSI Leach Test (Tc-99)

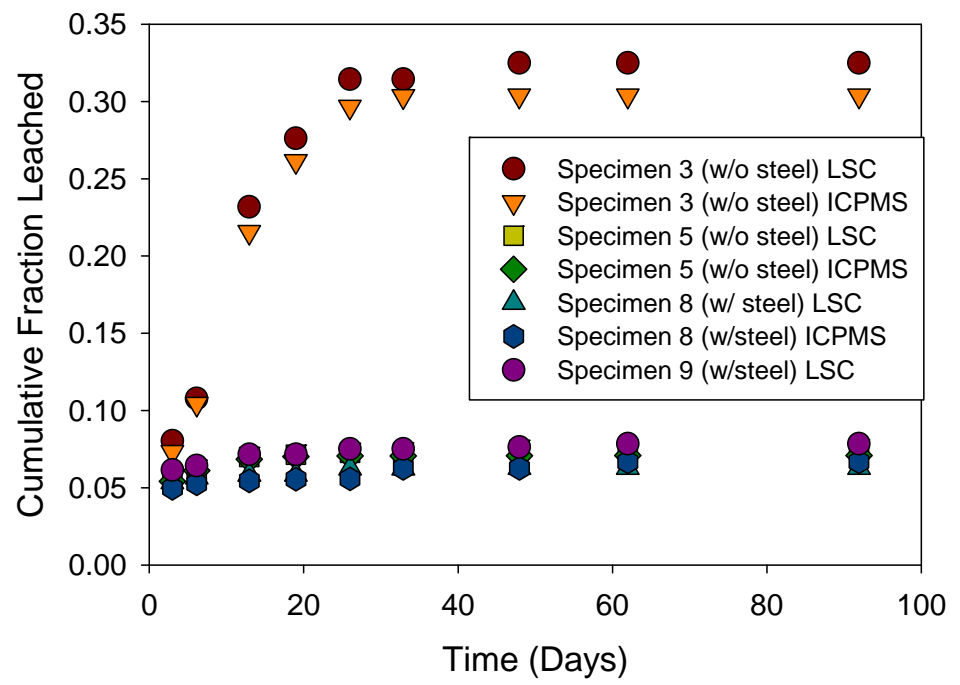

Figure 3.4. Static leach test: cumulative leaching fraction as a function of time for technetium-99 
ANSI Leach Test (U)

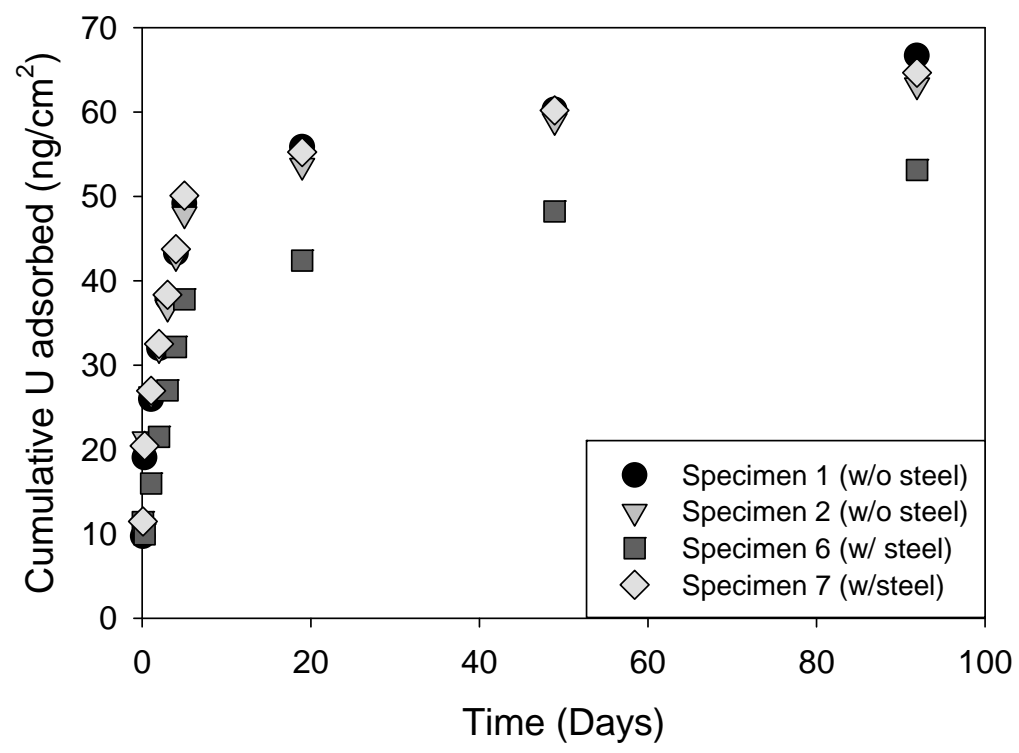

Figure 3.5. Dynamic leach test: cumulative uranium adsorbed as a function of time

ANSI Leach Test (U)

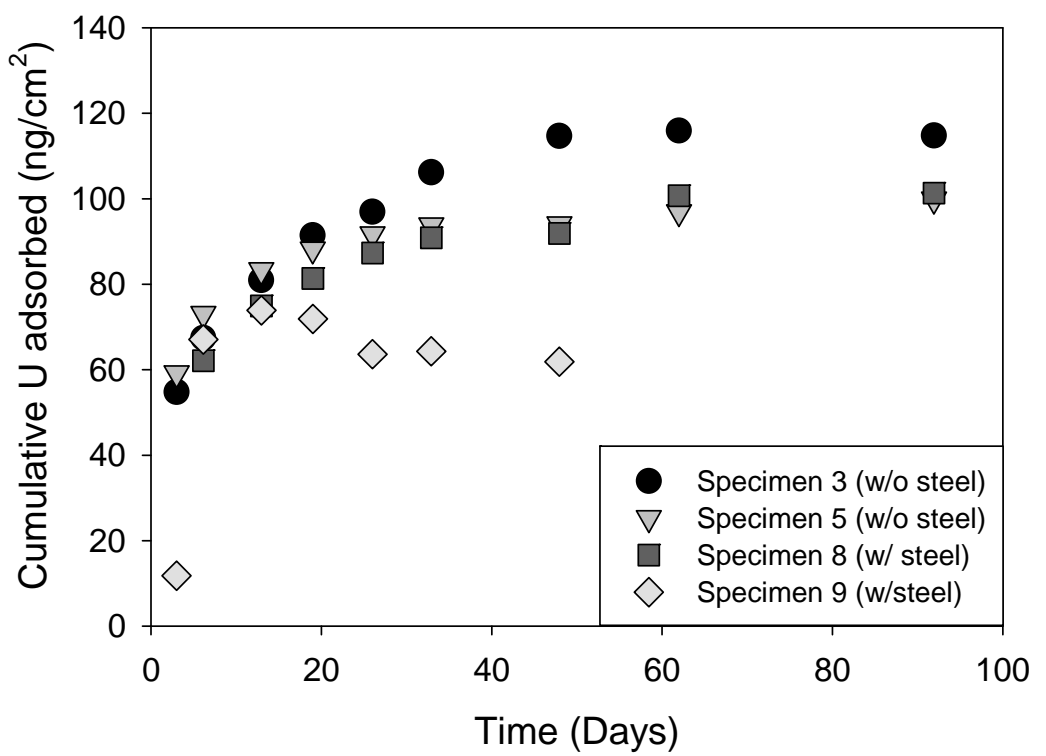

Figure 3.6. Static leach test: cumulative uranium adsorbed as a function of time

\subsubsection{Effective Diffusion Coefficients}

The calculated average effective diffusion coefficients and the corresponding leachability indices are listed in Table 3.3. The results of the ANSI leach test indicated that the average $\mathrm{D}_{\mathrm{ei}}$ for iodine-125 ranged from $3.59 \times 10^{-11}$ to $7.77 \times 10^{-11} \mathrm{~cm}^{2} / \mathrm{s}$, and the average $D_{\mathrm{ec}}$ ranged from $7.36 \times 10^{-11}$ to $1.32 \times 10^{-10} \mathrm{~cm}^{2} / \mathrm{s}$. Although, the cumulative leach fractions from specimens with and without the steel fibers showed slight 
differences, there were no significant differences in the calculated average diffusion coefficients. In all cases, the calculated $D_{\text {ec }}$ values were about twice as high the $D_{\text {ei }}$ values. As discussed in Section 3.1, these differences can be attributed to the lack of conformity with the conditions imposed by the semi-infinite solid leaching formulation.

The static leach test data yielded average $\mathrm{D}_{\mathrm{ei}}$ values for iodine- 125 that ranged from $3.06 \times 10^{-12}$ to $6.4 \times 10^{-11} \mathrm{~cm}^{2} / \mathrm{s}$, and average $\mathrm{D}_{\mathrm{ec}}$ values that ranged from $5.42 \times 10^{-12}$ to $6.79 \times 10^{-11} \mathrm{~cm}^{2} / \mathrm{s}$. Excluding the data from specimen 3, (which exhibited anomalous leaching behavior), there were no significant differences in diffusion coefficient values calculated from leaching of specimens with or without steel fibers. The data from the static tests yielded $\mathrm{D}_{\mathrm{ec}}$ values that were about $50 \%$ higher the average $\mathrm{D}_{\text {ei }}$ values.

The effective diffusion coefficients for iodine-125 derived from the dynamic leach (ANSI 16.1) tests are on average, about an order of magnitude higher than the values calculated from the static leach tests. These differences can be attributed to the differences in the leaching regime between these tests. In dynamic leach tests, all contact solution is renewed at each sampling time, whereas in static tests only about $15 \%$ of the contact solution is replaced. The dynamic leach tests subject the specimens to more aggressive leaching conditions; therefore, these tests yield higher effective diffusion coefficients (and higher leachability indices) than the values generated under moderate leaching conditions encountered in the static tests.

The data from the dynamic leach tests on technetium-99 indicated that the average $\mathrm{D}_{\mathrm{ei}}$ ranged from $1.61 \times 10^{-9}$ to $3.69 \times 10^{-9} \mathrm{~cm}^{2} / \mathrm{s}$, and the average $D_{\text {ec }}$ ranged from $3.39 \times 10^{-9}$ to $7.68 \times 10^{-9} \mathrm{~cm}^{2} / \mathrm{s}$ as measured by LSC. No significant differences were found in average diffusion coefficients between specimens with or without steel fibers, indicating that if a redox reaction occurred, it did not cause measurable leaching differences between the specimens. The $\mathrm{D}_{\mathrm{ec}}$ values for technetium-99 were about twice as high as the $D_{\text {ei }}$ values, indicating that leaching of concrete specimens in this test did not meet all the requirements inherent in the semi-infinite solid leaching model.

The static test data for technetium measured by LSC resulted in average $\mathrm{D}_{\mathrm{ei}}$ values that ranged from $2.4 \times 10^{-10}$ to $5.81 \times 10^{-9} \mathrm{~cm}^{2} / \mathrm{s}$, and average $D_{\mathrm{ec}}$ values that ranged from $4.3 \times 10^{-10}$ to $4.25 \times 10^{-9} \mathrm{~cm}^{2} / \mathrm{s}$. There were no significant differences between the diffusion coefficient values calculated from either the activity or mass measurements. Excluding the data from specimen 3, which exhibited anomalous leaching behavior, there were no significant differences in diffusion coefficient values calculated from leaching of specimens with or without steel fibers. As in the case of iodine-125, the data from the static tests (except for specimen 3 ) resulted in calculated $D_{\text {ec }}$ values which were about $50 \%$ higher than the average $D_{\text {ei }}$ values. Also, the more aggressive leaching regime used in the dynamic leach tests resulted in effective diffusion coefficients which were, on average, about an order of magnitude higher than the values calculated from the static leach tests. 
Table 3.3. Calculated effective diffusion coefficients and leaching indices for iodine- 125 and technetium-99 from dynamic and static leach tests

\begin{tabular}{|c|c|c|c|c|c|c|c|c|c|c|c|c|}
\hline \multicolumn{13}{|c|}{ Dynamic Leach Test } \\
\hline \multirow[b]{3}{*}{ Specimen \# } & \multicolumn{2}{|c|}{ Iodine-125 } & \multicolumn{2}{|c|}{ Technetium-99 ${ }^{[\mathrm{a}]}$} & \multicolumn{2}{|c|}{ Technetium-99 $^{[b]}$} & \multicolumn{2}{|c|}{ Iodine-125 } & \multicolumn{2}{|c|}{ Tc-99 ${ }^{[\mathrm{a}]}$} & \multicolumn{2}{|c|}{ Tc-99 $9^{[b]}$} \\
\hline & \multicolumn{6}{|c|}{ Effective Diffusion Coefficient $\left(\mathrm{cm}^{2} / \mathrm{s}\right)$} & \multicolumn{6}{|c|}{ Leachability Index } \\
\hline & $\mathrm{D}_{\mathrm{ei}}$ & $\mathrm{D}_{\mathrm{ec}}$ & $\mathrm{D}_{\mathrm{ei}}$ & $\mathrm{D}_{\mathrm{ec}}$ & $\mathrm{D}_{\mathrm{ei}}$ & $\mathrm{D}_{\mathrm{ec}}$ & $\mathrm{L}_{\mathrm{i}}$ & $\mathrm{L}_{\mathrm{c}}$ & $\mathrm{L}_{\mathrm{i}}$ & $\mathrm{L}_{\mathrm{c}}$ & $\mathrm{L}_{\mathrm{i}}$ & $\mathrm{L}_{\mathrm{c}}$ \\
\hline $1^{(\mathrm{c})}$ & $7.77 \times 10^{-11}$ & $1.32 \times 10^{-10}$ & $3.69 \times 10^{-9}$ & $7.68 \times 10^{-9}$ & $3.58 \times 10^{-9}$ & $7.36 \times 10^{-9}$ & 10.1 & 9.9 & 8.4 & 8.1 & 8.4 & 8.1 \\
\hline $2^{(\mathrm{c})}$ & $3.59 \times 10^{-11}$ & $7.36 \times 10^{-11}$ & $1.61 \times 10^{-9}$ & $3.39 \times 10^{-9}$ & & & 10.4 & 10.1 & 8.8 & 8.5 & & \\
\hline $6^{(\mathrm{d})}$ & $4.94 \times 10^{-11}$ & $1.00 \times 10^{-10}$ & $3.15 \times 10^{-9}$ & $5.18 \times 10^{-9}$ & & & 10.3 & 10.0 & 8.5 & 8.3 & & \\
\hline $7^{(\mathrm{d})}$ & $5.44 \times 10^{-11}$ & $9.17 \times 10^{-11}$ & $2.42 \times 10^{-9}$ & $4.03 \times 10^{-9}$ & & & 10.3 & 10.0 & 8.6 & 8.4 & & \\
\hline \multicolumn{13}{|c|}{ Static Leach Test } \\
\hline $3^{(\mathrm{c})}$ & $6.40 \times 10^{-11}$ & $6.79 \times 10^{-11}$ & $5.81 \times 10^{-9}$ & $4.25 \times 10^{-9}$ & $5.81 \times 10^{-9}$ & $3.77 \times 10^{-9}$ & 10.2 & 10.2 & 8.2 & 8.4 & 8.2 & 8.4 \\
\hline $5^{(\mathrm{c})}$ & $6.64 \times 10^{-12}$ & $1.08 \times 10^{-11}$ & $2.40 \times 10^{-10}$ & $5.36 \times 10^{-10}$ & $2.25 \times 10^{-10}$ & $5.02 \times 10^{-10}$ & 11.2 & 11.0 & 9.6 & 9.3 & 9.6 & 9.3 \\
\hline $8^{(\mathrm{d})}$ & $3.06 \times 10^{-12}$ & $5.42 \times 10^{-12}$ & $3.20 \times 10^{-10}$ & $4.30 \times 10^{-10}$ & $2.21 \times 10^{-10}$ & $3.78 \times 10^{-10}$ & 11.5 & 11.3 & 9.5 & 9.4 & 9.7 & 9.4 \\
\hline $9^{(\mathrm{d})}$ & $6.76 \times 10^{-12}$ & $8.02 \times 10^{-12}$ & $3.56 \times 10^{-10}$ & $5.85 \times 10^{-10}$ & $1.88 \times 10^{-10}$ & $2.07 \times 10^{-10}$ & 11.2 & 11.1 & 9.4 & 9.2 & 9.7 & 9.7 \\
\hline
\end{tabular}

(a) Technetium-99 activity measured by using LSC

(b) Technetium-99 concentration measured by using ICP-MS

(c) Specimen without steel fibers

(d) Specimen with steel fibers 
These tests showed that iodine-125 in these concrete formulations was about two orders of magnitude less leachable than technetium-99. Iodine-125 in these cement specimens also appear to be significantly less leachable (three to four orders of magnitude) than iodine in some of the Hanford Site grout formulations studied by Serne et al. (1992a,1992b). These differences in iodine leachability can be attributed to a different concrete formulation used in these studies as compared to Hanford Site grouts (which contained several waste types, higher waste loadings and different grout formulations). Previous studies have shown that leaching of technetium-99 varies as a function of waste type, waste loading (mix ratio), grout fluid density, and amount of blast furnace slag in the blend (Serne et al. 1992a, b; Tallent et al. 1988). These factors can cause technetium-99 leachability to range over four to five orders of magnitude (leachability index ranging from $\sim 7$ to 12 ). The leachabiliy index for technetium-99 in this study ranged from about 8.1 to 9.6 , which is within the range of 7 to 12 observed for various types of grouts.

Based on the data obtained in these studies, a selected range of effective diffusion coefficients and corresponding leachability indices for iodine-125 and technetium-99 were chosen for use in performance assessment calculations (Table 3.4).

Table 3.4. Range of effective diffusion coefficients and leachability indices for the selected mix design and contaminant loading

\begin{tabular}{ccccc}
\hline $\begin{array}{c}\text { Leaching } \\
\text { Condition }\end{array}$ & $\begin{array}{c}\text { Iodine-125 Effective } \\
\text { Diffusion Coefft }\left(\mathrm{cm}^{2} / \mathrm{s}\right)\end{array}$ & $\begin{array}{c}\text { Iodine-125 } \\
\text { Leachability Index }\end{array}$ & $\begin{array}{c}\text { Technetium-99 Effective } \\
\text { Diffusion Coefft }\left(\mathrm{cm}^{2} / \mathrm{s}\right)\end{array}$ & $\begin{array}{c}\text { Technetium-99 } \\
\text { Leachability Index }\end{array}$ \\
\hline Dynamic & $4 \times 10^{-11}-1 \times 10^{-10}$ & $10.4-10.0$ & $2 \times 10^{-9}-8 \times 10^{-9}$ & $8.7-8.1$ \\
Static & $3 \times 10^{-12}-7 \times 10^{-11}$ & $11.5-10.2$ & $2 \times 10^{-10}-6 \times 10^{-9}$ & $9.7-8.2$ \\
\hline
\end{tabular}

\subsection{Effect of Iron on the Release of Rhenium, lodine, and Technetium from Concrete}

Another set of dynamic leach tests was conducted to assess the effect of metallic iron particle incorporation on the leaching of contaminants in concrete specimens. Based on the laboratory concrete composition presented in Section 2, a set of concrete monoliths spiked with 1) I and Re, or 2) I and Tc, were prepared with $4 \%, 8 \%$, and $12 \%$ by mass, of metallic iron particles. Iron particles consisted of metallic iron ( -40 to +60 mesh) and reactive nanoscale zero valent iron particles (RNIP) (Toda America, Inc Schaumburg, IL). The characteristics of the specimens used are listed in Table 3.5. 
Table 3.5. Characteristics of cement specimens used in dynamic leach tests

\begin{tabular}{|c|c|c|c|c|c|c|c|c|c|c|c|c|}
\hline \multirow{2}{*}{$\begin{array}{c}\text { Specimen } \\
\text { No. }\end{array}$} & \multirow{2}{*}{$\begin{array}{l}\text { Length } \\
(\mathrm{cm})\end{array}$} & \multirow{2}{*}{$\begin{array}{l}\text { Diameter } \\
(\mathrm{cm})\end{array}$} & \multirow{2}{*}{$\begin{array}{c}\text { Surface } \\
\text { Area }\left(\mathrm{cm}^{2}\right)\end{array}$} & \multirow{2}{*}{$\begin{array}{l}\text { Volume } \\
\left(\mathrm{cm}^{3}\right)\end{array}$} & \multicolumn{5}{|c|}{ Iron } & \multicolumn{3}{|c|}{ Contaminant } \\
\hline & & & & & Metal & RNIP & $4 \%$ & $8 \%$ & $12 \%$ & I & $\mathrm{Re}$ & Tc \\
\hline 1 & 3.67 & 2.50 & 38.65 & 18.02 & $\mathrm{x}$ & & $\mathrm{x}$ & & & $\mathrm{x}$ & $\mathrm{x}$ & \\
\hline 2 & 3.15 & 2.49 & 34.48 & 15.41 & $\mathrm{x}$ & & & $\mathrm{x}$ & & $\mathrm{x}$ & $\mathrm{x}$ & \\
\hline 3 & 3.96 & 2.51 & 40.99 & 19.50 & $\mathrm{x}$ & & & & $\mathrm{x}$ & $\mathrm{x}$ & $\mathrm{x}$ & \\
\hline 4 & 4.50 & 2.50 & 45.17 & 22.06 & & $\mathrm{x}$ & $\mathrm{x}$ & & & $\mathrm{x}$ & $\mathrm{x}$ & \\
\hline 5 & 4.18 & 2.51 & 42.87 & 20.70 & & $\mathrm{x}$ & & $\mathrm{x}$ & & $\mathrm{x}$ & $\mathrm{x}$ & \\
\hline 6 & 4.44 & 2.51 & 44.91 & 21.96 & & $\mathrm{x}$ & & & $\mathrm{x}$ & $\mathrm{x}$ & $\mathrm{x}$ & \\
\hline 7 & 4.48 & 2.52 & 45.32 & 22.25 & & $\mathrm{x}$ & $\mathrm{x}$ & & & $\mathrm{x}$ & & $\mathrm{x}$ \\
\hline 8 & 4.39 & 2.49 & 44.12 & 21.41 & & $\mathrm{x}$ & & $\mathrm{x}$ & & $\mathrm{x}$ & & $\mathrm{x}$ \\
\hline 9 & 4.22 & 2.50 & 42.86 & 20.64 & & $\mathrm{x}$ & & & $\mathrm{x}$ & $\mathrm{x}$ & & $\mathrm{x}$ \\
\hline
\end{tabular}

The concrete monoliths were subjected to dynamic leach tests (ANSI-16.1) to determine the rate of leaching of I, Re, and Tc in concrete, based on the inclusion of iron, and to determine the cumulative fraction leached and effective diffusion coefficient. The test protocol was slightly modified in that actual groundwater from the Hanford Site was used as the leachant instead of the demineralized water specified in ANSI-16.1. The composition of Hanford Site groundwater is listed in Table 3.6.

Table 3.6. Composition of Hanford Site groundwater used in second experiment

\begin{tabular}{cccc}
\hline Constituent & $\begin{array}{c}\text { Conc. } \\
(\mathrm{mg} / \mathrm{L})\end{array}$ & Constituent & $\begin{array}{c}\text { Conc. } \\
(\mathrm{mg} / \mathrm{L})\end{array}$ \\
\hline $\mathrm{Ba}$ & 0.043 & $\mathrm{Mg}$ & 27.29 \\
$\mathrm{Ca}$ & 35.27 & $\mathrm{Na}$ & 73.71 \\
$\mathrm{Cl}$ & 12.24 & $\mathrm{P}$ & $<0.025$ \\
$\mathrm{CO}_{3}$ & 191.59 & $\mathrm{Sr}$ & 0.14 \\
$\mathrm{~K}$ & 15.19 & $\mathrm{Si}$ & 35.37 \\
$\mathrm{~F}$ & 0.83 & $\mathrm{SO}_{4}$ & 167.28 \\
$\mathrm{Fe}$ & 0.14 & $\mathrm{pH}$ & $8.12(\mathrm{SU})$ \\
\hline
\end{tabular}

\subsubsection{Results and Discussion}

Figure 3.7 presents the cumulative fraction of I, Re, and Tc, respectively, released as a function of time during dynamic leach testing. The results indicate that in the dynamic leach test all contaminants leach rapidly during the first 5 days. Subsequent release continued at an attenuated rate for the remainder of the test for all contaminants. 

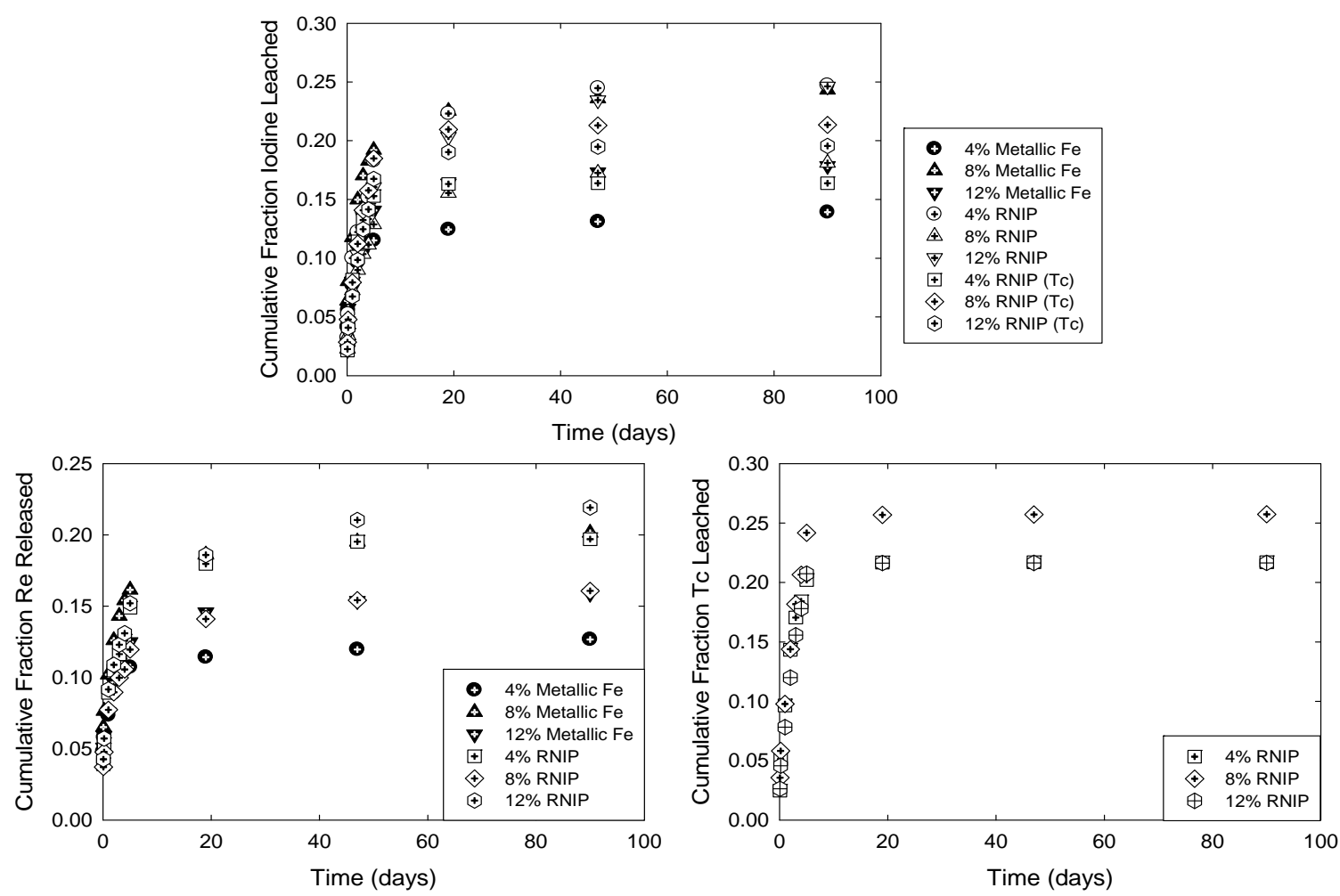

Figure 3.7. Dynamic leach test: cumulative leaching fraction as a function of time for I, Re, and Tc

Table 3.7 presents the effective diffusion coefficient for I and Re at $4 \%, 8 \%$, and $12 \%$ iron as metallic iron (-40 to +60 mesh) and as RNIP. The leaching indices indicate that the presence of metallic iron particles or RNIP in concentrations ranging from $4 \%$ to $12 \%$ by mass did not significantly affect the leachability of Re and I from waste-form specimens. However, inclusion of RNIP relative to metallic iron particles significantly increases the leachability of Re and I from waste-form specimens. The leaching behavior of I and Re in the presence of RNIP was at a significantly increased rate throughout the duration of the test. The RNIP formulation consists of elemental iron, magnetite, water, and a water soluble polymer to maintain a stable iron slurry. It is hypothesized that the polymer may form a surface coating on the iron particles, which reduces their reactivity and may inhibit reaction with redox-sensitive contaminants within the concrete waste forms.

Table 3.8 presents the calculated effective diffusion coefficient for Tc and I at $4 \%, 8 \%$, and $12 \%$ iron as RNIP. The leaching indices for I were comparable to those previously quantified from waste forms containing $4 \%, 8 \%$, and $12 \%$ iron, as metallic iron (-40 to +60 mesh) and RNIP (Table 3.7). The leaching indices indicate that in the presence of $4 \%$ and $8 \%$ ZVI, Tc had higher leachability than Re. However, there was no difference in the leachability of Tc and Re when the waste form contained $12 \% \mathrm{ZVI}$.

Deviations in the chemical reduction of pertechnetate and perrhenate in the presence of organic ligands have been recently noted (Maset et al. 2006). Our results indicated that the presence of organic ligands did not cause a measurable difference in the solubility of Tc. Moreover, Wellman et al. (2006) noted a decrease in the diffusion of Tc versus Re from concrete waste forms. Thus, although the pertechnetate and perrhenate anions are comparable surrogates based on size, Re does not function as an analogue for Tc under redox conditions. 
Table 3.7. Leach index data for Re and I as a functions of metallic iron-particle concentration

\begin{tabular}{|c|c|c|c|c|c|c|c|c|}
\hline \multicolumn{5}{|c|}{$\mathrm{Re} / \mathrm{I}$ concrete column with $4 \%$ Metallic Fe } & \multicolumn{4}{|c|}{ Re/I concrete column with $4 \%$ RNIP } \\
\hline \multirow[b]{2}{*}{ Time (hr) } & $\operatorname{Re}$ & $\mathrm{I}$ & $\operatorname{Re}$ & $\mathrm{I}$ & $\operatorname{Re}$ & I & $\mathrm{Re}$ & I \\
\hline & D eff $\mathrm{cm}^{2} / \mathrm{s}$ & D eff $\mathrm{cm}^{2} / \mathrm{s}$ & $\begin{array}{l}\text { Leach } \\
\text { index }\end{array}$ & $\begin{array}{l}\text { Leach } \\
\text { index }\end{array}$ & $\mathrm{D}$ eff $\mathrm{cm}^{2} / \mathrm{s}$ & D eff $\mathrm{cm}^{2} / \mathrm{s}$ & $\begin{array}{l}\text { Leach } \\
\text { index }\end{array}$ & $\begin{array}{l}\text { Leach } \\
\text { index }\end{array}$ \\
\hline 2 & $2.20 \mathrm{E}-07$ & $1.64 \mathrm{E}-07$ & 6.7 & 6.8 & $1.6 \mathrm{E}-07$ & $1.1 \mathrm{E}-07$ & 6.8 & 7.0 \\
\hline 7 & $2.00 \mathrm{E}-09$ & 4.31E-09 & 8.7 & 8.4 & 4.5E-09 & $9.3 \mathrm{E}-09$ & 8.3 & 8.0 \\
\hline 24 & $1.94 \mathrm{E}-09$ & $3.55 \mathrm{E}-09$ & 8.7 & 8.4 & $1.1 \mathrm{E}-08$ & $2.0 \mathrm{E}-08$ & 7.95 & 7.7 \\
\hline 48 & $8.63 \mathrm{E}-10$ & $1.35 \mathrm{E}-09$ & 9.1 & 8.9 & $9.8 \mathrm{E}-10$ & 2.0E-09 & 9.0 & 8.7 \\
\hline 72 & $3.39 \mathrm{E}-10$ & $2.77 \mathrm{E}-10$ & 9.5 & 9.6 & $3.6 \mathrm{E}-10$ & 7.7E-10 & 9.4 & 9.1 \\
\hline 96 & $3.35 \mathrm{E}-11$ & $5.54 \mathrm{E}-11$ & 10.5 & 10.3 & $1.9 \mathrm{E}-10$ & $3.4 \mathrm{E}-10$ & 9.7 & 9.5 \\
\hline 120 & $8.88 \mathrm{E}-12$ & $1.29 \mathrm{E}-11$ & 11.1 & 10.9 & $9.2 \mathrm{E}-10$ & $1.7 \mathrm{E}-09$ & 9.0 & 8.8 \\
\hline 456 & $2.38 \mathrm{E}-11$ & $4.19 \mathrm{E}-11$ & 10.6 & 10.4 & $5.1 \mathrm{E}-10$ & $8.8 \mathrm{E}-10$ & 9.3 & 9.1 \\
\hline 1200 & $4.70 \mathrm{E}-12$ & $7.16 \mathrm{E}-12$ & 11.3 & 11.1 & $4.0 \mathrm{E}-11$ & 7.7E-11 & 10.4 & 10.1 \\
\hline \multirow{2}{*}{2208} & $4.12 \mathrm{E}-12$ & $5.44 \mathrm{E}-12$ & 11.4 & 11.3 & $2.9 \mathrm{E}-13$ & $5.7 \mathrm{E}-13$ & 12.5 & 12.3 \\
\hline & & ${ }^{(\mathrm{a})} \mathrm{L}$ bar $=$ & 9.7 & 9.6 & & ${ }^{(a)} \mathrm{L}$ bar $=$ & 9.3 & 9.0 \\
\hline \multicolumn{5}{|c|}{$\mathrm{Re} / \mathrm{I}$ concrete column with $8 \%$ Metallic Fe } & \multicolumn{4}{|c|}{$\mathrm{Re} / \mathrm{I}$ concrete column with $8 \%$ RNIP } \\
\hline \multirow[b]{2}{*}{ Time (hr) } & $\mathrm{Re}$ & $\mathrm{I}$ & $\operatorname{Re}$ & $\mathrm{I}$ & $\mathrm{Re}$ & $\mathrm{I}$ & $\mathrm{Re}$ & I \\
\hline & D eff $\mathrm{cm}^{2} / \mathrm{s}$ & D eff $\mathrm{cm}^{2} / \mathrm{s}$ & $\begin{array}{l}\text { Leach } \\
\text { index }\end{array}$ & $\begin{array}{l}\text { Leach } \\
\text { index }\end{array}$ & $\mathrm{D}$ eff $\mathrm{cm}^{2} / \mathrm{s}$ & D eff $\mathrm{cm}^{2} / \mathrm{s}$ & $\begin{array}{l}\text { Leach } \\
\text { index }\end{array}$ & $\begin{array}{l}\text { Leach } \\
\text { index }\end{array}$ \\
\hline 2 & $3.70 \mathrm{E}-07$ & $3.53 \mathrm{E}-07$ & 6.4 & 6.5 & $1.4 \mathrm{E}-07$ & $5.3 \mathrm{E}-08$ & 6.9 & 7.3 \\
\hline 7 & 2.69E-09 & 5.85E-09 & 8.6 & 8.2 & $2.8 \mathrm{E}-08$ & $1.5 \mathrm{E}-08$ & 7.6 & 7.8 \\
\hline 24 & $5.14 \mathrm{E}-09$ & $1.10 \mathrm{E}-08$ & 8.3 & 8.0 & $2.1 \mathrm{E}-08$ & $1.9 \mathrm{E}-08$ & 7.7 & 7.7 \\
\hline 48 & $2.11 \mathrm{E}-09$ & $3.76 \mathrm{E}-09$ & 8.7 & 8.4 & $1.2 \mathrm{E}-08$ & $1.2 \mathrm{E}-08$ & 7.9 & 7.9 \\
\hline 72 & $7.23 \mathrm{E}-10$ & $1.04 \mathrm{E}-09$ & 9.1 & 9.0 & $8.5 \mathrm{E}-09$ & $9.2 \mathrm{E}-09$ & 8.1 & 8.0 \\
\hline 96 & $2.30 \mathrm{E}-10$ & $3.07 \mathrm{E}-10$ & 9.6 & 9.5 & $6.8 \mathrm{E}-09$ & 7.6E-09 & 8.2 & 8.1 \\
\hline 120 & $8.47 \mathrm{E}-11$ & $1.32 \mathrm{E}-10$ & 10.1 & 9.9 & $6.7 \mathrm{E}-09$ & $7.8 \mathrm{E}-09$ & 8.2 & 8.1 \\
\hline 456 & $2.98 \mathrm{E}-10$ & $5.40 \mathrm{E}-10$ & 9.5 & 9.3 & $3.9 \mathrm{E}-09$ & 4.7E-09 & 8.4 & 8.3 \\
\hline 1200 & $1.30 \mathrm{E}-11$ & $1.79 \mathrm{E}-11$ & 10.9 & 10.7 & $1.5 \mathrm{E}-09$ & $1.9 \mathrm{E}-09$ & 8.8 & 8.7 \\
\hline \multirow[t]{2}{*}{2208} & $3.32 \mathrm{E}-12$ & 4.69E-12 & 11.5 & 11.3 & 7.9E-10 & $1.0 \mathrm{E}-09$ & 9.1 & 9.0 \\
\hline & & ${ }^{(a)} \mathrm{L}$ bar $=$ & 9.3 & 9.1 & & ${ }^{(a)} \mathrm{L}$ bar $=$ & 8.1 & 8.1 \\
\hline \multicolumn{5}{|c|}{ Re/I concrete column with $12 \%$ Metallic Fe } & \multicolumn{4}{|c|}{ Re/I concrete column with $12 \%$ RNIP } \\
\hline \multirow[b]{2}{*}{ Time (hr) } & $\mathrm{Re}$ & $\mathrm{I}$ & $\mathrm{Re}$ & I & $\mathrm{Re}$ & I & $\mathrm{Re}$ & $\mathrm{I}$ \\
\hline & $\mathrm{D}$ eff $\mathrm{cm}^{2} / \mathrm{s}$ & $\mathrm{D}$ eff $\mathrm{cm}^{2} / \mathrm{s}$ & $\begin{array}{l}\text { Leach } \\
\text { index }\end{array}$ & $\begin{array}{l}\text { Leach } \\
\text { index }\end{array}$ & D eff $\mathrm{cm}^{2} / \mathrm{s}$ & D eff $\mathrm{cm}^{2} / \mathrm{s}$ & $\begin{array}{l}\text { Leach } \\
\text { index }\end{array}$ & $\begin{array}{l}\text { Leach } \\
\text { index }\end{array}$ \\
\hline 2 & $2.57 \mathrm{E}-07$ & $2.00 \mathrm{E}-07$ & 6.6 & 6.7 & $1.9 \mathrm{E}-07$ & 5.1E-08 & 6.7 & 7.3 \\
\hline 7 & $1.44 \mathrm{E}-09$ & $3.28 \mathrm{E}-09$ & 8.8 & 8.5 & 4.2E- 08 & $1.7 \mathrm{E}-08$ & 7.4 & 7.8 \\
\hline 24 & $2.18 \mathrm{E}-09$ & 4.28E-09 & 8.7 & 8.4 & $3.1 \mathrm{E}-08$ & $2.3 \mathrm{E}-08$ & 7.5 & 7.6 \\
\hline 48 & $1.67 \mathrm{E}-09$ & $2.80 \mathrm{E}-09$ & 8.8 & 8.6 & $1.8 \mathrm{E}-08$ & $1.6 \mathrm{E}-08$ & 7.8 & 7.8 \\
\hline 72 & $5.17 \mathrm{E}-10$ & $7.10 \mathrm{E}-10$ & 9.3 & 9.1 & $1.3 \mathrm{E}-08$ & $1.3 \mathrm{E}-08$ & 7.9 & 7.9 \\
\hline 96 & $1.40 \mathrm{E}-10$ & $2.07 \mathrm{E}-10$ & 9.9 & 9.7 & $1.1 \mathrm{E}-08$ & $1.1 \mathrm{E}-08$ & 8.0 & 8.0 \\
\hline 120 & $5.72 \mathrm{E}-11$ & $7.04 \mathrm{E}-11$ & 10.2 & 10.2 & $1.1 \mathrm{E}-08$ & $1.2 \mathrm{E}-08$ & 8.0 & 7.9 \\
\hline 456 & $2.24 \mathrm{E}-10$ & $2.73 \mathrm{E}-10$ & 9.7 & 9.6 & $6.9 \mathrm{E}-09$ & 8.3E-09 & 8.2 & 8.1 \\
\hline 1200 & $1.05 \mathrm{E}-11$ & $1.46 \mathrm{E}-11$ & 11.0 & 10.8 & $3.0 \mathrm{E}-09$ & $3.7 \mathrm{E}-09$ & 8.5 & 8.4 \\
\hline \multirow[t]{2}{*}{2208} & $2.29 \mathrm{E}-12$ & $2.57 \mathrm{E}-12$ & 11.6 & 11.6 & $1.5 \mathrm{E}-09$ & 1.9E-09 & 8.8 & 8.7 \\
\hline & & ${ }^{(a)} \mathrm{L}$ bar $=$ & 9.5 & 9.3 & & ${ }^{(\mathrm{a})} \mathrm{L}$ bar = & 7.9 & 7.9 \\
\hline
\end{tabular}


Table 3.8. Leach index data for Tc and I as a functions of RNIP particle concentration

\begin{tabular}{|c|c|c|c|c|}
\hline & Tc & I & $\mathrm{Tc}$ & $\mathrm{I}$ \\
\hline Time (hr) & $\mathrm{D} \mathrm{eff} \mathrm{cm}^{2} / \mathrm{s}$ & $\mathrm{D}$ eff $\mathrm{cm}^{2} / \mathrm{s}$ & Leach index & Leach index \\
\hline \multicolumn{5}{|c|}{$\mathrm{Tc} / \mathrm{I}$ concrete column with $4 \%$ RNIP } \\
\hline 2 & $6.5 \mathrm{E}-08$ & $4.8 \mathrm{E}-08$ & 7.2 & 7.3 \\
\hline 7 & $3.4 \mathrm{E}-08$ & $2.5 \mathrm{E}-08$ & 7.5 & 7.6 \\
\hline 24 & 3.4E-08 & $2.5 \mathrm{E}-08$ & 7.5 & 7.6 \\
\hline 48 & 3.1E-08 & $2.0 \mathrm{E}-08$ & 7.5 & 7.7 \\
\hline 72 & $2.6 \mathrm{E}-08$ & $1.6 \mathrm{E}-08$ & 7.6 & 7.8 \\
\hline 96 & 2.1E-08 & $1.3 \mathrm{E}-08$ & 7.7 & 7.9 \\
\hline 120 & 2.0E-08 & $1.1 \mathrm{E}-08$ & 7.7 & 7.9 \\
\hline 456 & $9.5 \mathrm{E}-09$ & $5.4 \mathrm{E}-09$ & 8.0 & 8.3 \\
\hline 1200 & $3.2 \mathrm{E}-09$ & $1.8 \mathrm{E}-09$ & 8.5 & 8.7 \\
\hline \multirow[t]{2}{*}{2208} & $1.5 \mathrm{E}-09$ & $8.5 \mathrm{E}-10$ & 8.8 & 9.1 \\
\hline & & $\mathrm{L}$ bar $=$ & 7.8 & 8.0 \\
\hline \multicolumn{5}{|c|}{ Tc/I concrete column with $8 \%$ RNIP } \\
\hline 2 & $1.3 \mathrm{E}-07$ & $8.4 \mathrm{E}-08$ & 6.9 & 7.1 \\
\hline 7 & 4.2E-08 & $2.9 \mathrm{E}-08$ & 7.4 & 7.5 \\
\hline 24 & $3.5 \mathrm{E}-08$ & $2.3 \mathrm{E}-08$ & 7.5 & 7.6 \\
\hline 48 & 3.0E-08 & $1.8 \mathrm{E}-08$ & 7.5 & 7.7 \\
\hline 72 & 2.9E-08 & $1.7 \mathrm{E}-08$ & 7.5 & 7.8 \\
\hline 96 & $2.6 \mathrm{E}-08$ & $1.5 \mathrm{E}-08$ & 7.6 & 7.8 \\
\hline 120 & $2.8 \mathrm{E}-08$ & $1.6 \mathrm{E}-08$ & 7.6 & 7.8 \\
\hline 456 & $1.3 \mathrm{E}-08$ & 8.7E-09 & 7.9 & 8.1 \\
\hline 1200 & 4.3E-09 & 3.0E-09 & 8.4 & 8.5 \\
\hline \multirow[t]{2}{*}{2208} & 2.0E-09 & 1.4E-09 & 8.7 & 8.9 \\
\hline & & $\mathrm{L}$ bar $=$ & 7.7 & 7.9 \\
\hline \multicolumn{5}{|c|}{$\mathrm{Tc} / \mathrm{I}$ concrete column with $12 \%$ RNIP } \\
\hline 2 & $7.0 \mathrm{E}-08$ & $5.2 \mathrm{E}-08$ & 7.2 & 7.3 \\
\hline 7 & 2.6E-08 & $2.1 \mathrm{E}-08$ & 7.6 & 7.7 \\
\hline 24 & 2.2E-08 & $1.6 \mathrm{E}-08$ & 7.7 & 7.8 \\
\hline 48 & 2.1E-08 & $1.4 \mathrm{E}-08$ & 7.7 & 7.9 \\
\hline 72 & 2.1E-08 & $1.3 \mathrm{E}-08$ & 7.7 & 7.9 \\
\hline 96 & 1.9E-08 & $1.2 \mathrm{E}-08$ & 7.7 & 7.9 \\
\hline 120 & $2.0 \mathrm{E}-08$ & $1.3 \mathrm{E}-08$ & 7.7 & 7.8 \\
\hline 456 & 9.1E-09 & 7.0E-09 & 8.0 & 8.2 \\
\hline 1200 & $3.0 \mathrm{E}-09$ & 2.4E-09 & 8.5 & 8.6 \\
\hline \multirow[t]{2}{*}{2208} & 1.4E-09 & $1.2 \mathrm{E}-09$ & 8.9 & 8.9 \\
\hline & & $\mathrm{L}$ bar $=$ & 7.9 & 8.0 \\
\hline
\end{tabular}




\subsection{Summary of ANSI 16.1 Leaching Experiments}

The results of the two sets of leaching experiments are summarized as follows:

- Use of $4 \%$ by mass of steel fiber did not noticeably affect the leachability of either I or Tc.

- The first set of experiments indicated that I leached significantly less (LI: 10.0) as compared to Tc (LI: 8.4).

- In the second set of experiments, use of increasing mass of Fe particles $(4,8$, and $12 \%$ of $40-60$ mesh size) did not affect the leachability of either I or Re indicating the ineffectiveness of Fe particles to retard the leaching of these contaminants, perhaps due to potential passivation of the metallic $\mathrm{Fe}$ surface by oxide layers.

- Inclusion of RNIP relative to metallic Fe particles showed up to an order of magnitude increases in leachability of Tc/Re and I. The presence of polymeric dispersants in RNIP may be a cause for this enhanced leaching.

- The LI of Re and I in Fe-containing specimens ranged from $9.3-9.7$ and $9.1-9.6$ respectively.

- The range of LI for Tc observed in these studies $(7.7-7.9)$ is within the range of $7.0-12.0$ observed for various types of grouts. 


\subsection{Characterization of Historic Concrete Samples and Supercritically Carbonated Concrete Specimens}

Previous studies of concrete specimens have shown that carbonation would have an armoring effect that would increase the diffusion path of contaminant radionuclides through increasing tortuosity. Currently, there is a lack of data on the rate of carbonation of concrete surfaces that have weathered for decades at the Hanford Site.

\subsection{Carbonation Studies of Historic Concrete}

To gain some understanding of the rates of natural carbonation of concrete at the Hanford Site, we used core samples obtained from concrete structures from the Hanford Site that had weathered for about 14, 28, and 57 years, respectively (Table 4.1).

Table 4.1. Concrete cores used in carbonation studies

\begin{tabular}{ccc}
\hline Core \# & $\begin{array}{c}\text { Specimen } \\
\text { Designation }\end{array}$ & $\begin{array}{c}\text { Concrete Age } \\
\text { (Yrs) }\end{array}$ \\
\hline 3 & 213J & 57 \\
1 & $622 \mathrm{C}$ & 28 \\
2 & FLTF & 14 \\
\hline
\end{tabular}

Transverse slices and thin sections from these concrete cores were characterized by CTL Laboratories, Inc. ${ }^{1}$, using techniques such as petrographic microscopy and phenolphthalein $\mathrm{pH}$ indicator. The results from these studies are listed in Table 4.2.

Table 4.2. Characteristics of selected concrete cores from the Hanford Site

\begin{tabular}{llll}
\hline \multicolumn{1}{c}{ Characteristic } & \multicolumn{1}{c}{ Specimen 213J } & \multicolumn{1}{c}{ Specimen 622C } & \multicolumn{1}{c}{ Specimen FLTF } \\
\hline Carbonation depth (mm) & $48-53$ & $2-8$ & $1-10$ \\
Air content (\%) & $1-2 \%$ & $2-4 \%$ & $4-5 \%$ \\
Water/cement ratio & $0.52-0.57$ & $0.50-0.55$ & $0.50-0.55$ \\
Secondary deposits & $\begin{array}{l}\text { None in outer } 50 \mathrm{~mm}-\text { minor } \\
\text { ettringite lining voids }\end{array}$ & Ettringite lining voids & $\begin{array}{l}\text { Abundant ettringite lining } \\
\text { voids }\end{array}$ \\
Micro-cracks & Common in outer 50 mm & Minor & Minor \\
Unit weight (pcf) & 148 & 152 & 153 \\
Steel & $\# 4 \sim 80$ mm cover & None & \#4 $\sim 103$ mm cover \\
Aggregates & Well-graded siliceous gravel, & Well-graded siliceous & Well-graded siliceous \\
& 21 mm top size & gravel, 23 mm top size & gravel, 19 mm top size \\
Paste-aggregate bond & Moderately tight to & Moderately tight & Moderately tight \\
& moderately weak & & \\
\hline
\end{tabular}

\footnotetext{
${ }^{1}$ Skokie, Illinois 60077.
} 
The data (Table 4.2) showed that the depth of carbonation increased with the increasing age of concrete. In the oldest specimen (213J), the carbonation had extended to about $50 \mathrm{~mm}$ in to the concrete wall. Although we have limited data, we can estimate that the rate of carbonation of concrete at the Hanford Site ranges approximately from 0.4 to $0.9 \mathrm{~cm}$ per year. Clearly, the rate of carbonation would be affected by several factors, such as concrete composition, porosity, and the degree of exposure to weathering. Additionally, the observations indicated that as the concrete ages and carbonation extends to greater depths, an increasing degree of micro-cracking may occur. Such increases in micro-cracking may offset the effects of carbonation in that the rate of diffusion and leaching of contaminants may not change significantly as the concrete ages through chemical weathering.

\subsection{Supercritical Carbonation and Micro-Cracking of Concrete Specimens}

Four concrete monoliths, were subjected to petrographic studies in an effort to evaluate the extent of carbonation and the degree of micro-cracking if any was induced by carbonation (using supercritical carbon dioxide). Petrographic studies were also used to discern any correlations between the diffusion of iodine and rhenium from the monoliths (Table 4.3). The petrographic studies were conducted in general accordance with the relevant portions of ASTM C 856, Standard Practice for Petrographic Examination of Hardened Concrete. The results are summarized in Table 4.3.

Table 4.3. Concrete monoliths subject to carbonation/micro-cracking analysis

\begin{tabular}{ll}
\hline CS-II-4\% & No Iron, Not Carbonated, 4\% Moisture Content \\
CS-IV-4\% & Iron, Not Carbonated, 4\% Moisture Content \\
CS-I-7\% & No Iron, Carbonated, 7\% Moisture Content \\
CS-III-7\% & Iron, Carbonated, 7\% Moisture Content \\
\hline
\end{tabular}

\subsubsection{Petrographic Analyses}

\section{No Iron, Not Carbonated, 4\% Moisture Content}

The concrete monolith hydration characteristics are normal. Partly hydrated cement grains are coated with transparent, colorless hydration rims. Portlandite (calcium hydroxide) is relatively abundant. The crystals are small and uniformly distributed. The concrete is air entrained with an estimated 6 to 8 percent small, spherical air voids. Clustering of the voids is common. Small air voids in the outer $1 \mathrm{~mm}$ of the concrete are lined with ettringite crystals. Concrete volume is estimated at 30 to 35 percent; interpreted water-cementitious materials ratio is 0.53 to 0.58 (Figure 4.1 and Table 4.4).

The surface of the concrete monolith in contact with the sediment half-cell is carbonated to a depth of $2 \mathrm{~mm}$ (Figure 4.1b). The concrete surfaces are carbonated to an average depth of $0.4 \mathrm{~mm}$ (Figure $4.1 \mathrm{~b}$ ). The carbonated concrete has a fine-grained texture and consists of impure calcium carbonate. No significant cracks or micro-cracks are observed (Figure 4.1 and Table 4.4). 

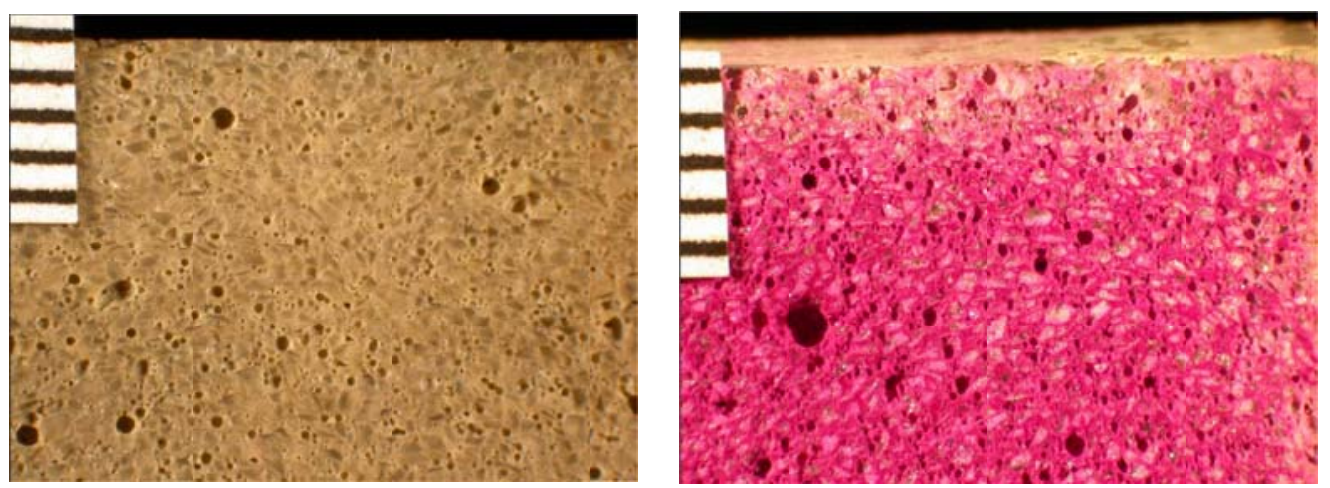

Figure 4.1. Left: Lapped surface of CS-II-4\%. The top surface shown in the photo is a cast surface. Air voids are non-uniformly distributed. Right: Close view of a fracture surface treated with phenolphthalein $\mathrm{pH}$ indicator solution. Non-carbonated paste is stained magenta. A cast surface is at the top of the photo. Scale at left is marked in millimeter increments.

\section{Iron, Not Carbonated, 4\% Moisture Content}

The concrete monolith hydration characteristics are normal. Partly hydrated cement grains are coated with transparent, colorless hydration rims. The level of fly ash replacement/substitution is moderate to high, based on the relative proportions of unhydrated and partly hydrated cement and residual fly ash. Portlandite (calcium hydroxide) is relatively abundant. The crystals are small and uniformly distributed. The concrete is air entrained with an estimated 5 to 7 percent small, spherical air voids; clustering of the voids is common. Concrete monolith volume is estimated at 30 to 35 percent and the interpreted watercementitious materials ratio is 0.50 to 0.55 . No secondary precipitates were observed (Figure 4.2a and Table 4.4).

The surface of the concrete monolith in contact with the sediment half-cell is carbonated to a depth of 1 to $2 \mathrm{~mm}$ (Figure 4.2b). The monolith surfaces are carbonated to an average depth of $0.4 \mathrm{~mm}$ (Figure $4.2 \mathrm{~b}$ ). The carbonated monolith has a fine-grained texture and consists of impure calcium carbonate. No significant cracks or micro-cracks are observed (Figure 4.2 and Table 4.4).

\section{No Iron, Carbonated, 7\% Moisture Content}

The interior portion of the monolith is dark beige-gray and white (secondary deposits). The paste in the outer portion of the monolith is medium beige-gray. The concrete contains scattered unhydrated portland cement clinker particles, abundant partly hydrated portland cement grains, and abundant residual fly ash particles. Cement hydration characteristics are normal. Partly hydrated cement grains are coated with transparent, colorless hydration rims. Portlandite (calcium hydroxide) is relatively abundant. The crystals are small and uniformly distributed. The concrete is air entrained with an estimated 7 to 9 percent small, spherical air voids. Air voids in the interior portion of the concrete are lined with ettringite deposits. Clustering and coalescence of the voids are common. The concrete volume is estimated at 30 to 35 percent, interpreted water-cementitious materials ratio is 0.53 to 0.58 (Figure $4.3 \mathrm{a}$ and Table 4.4).

The concrete is carbonated to a depth of 5 to $8 \mathrm{~mm}$ from the outside surfaces (top and cast surfaces) (Figure 4.3b). The carbonated paste has a fine-grained texture and consists of impure calcium carbonate. No significant cracks or micro-cracks are observed (Figure 4.3 and Table 4.4). 


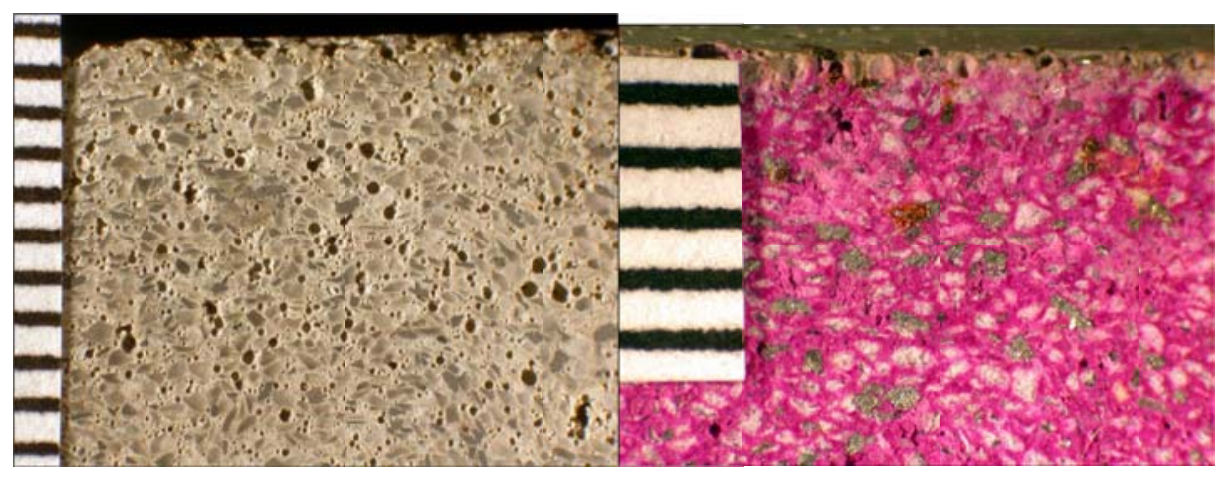

Figure 4.2. Left: Lapped surface of CS-IV-4\%. The top surface shown in the photo is a cast surface. Clustering of the entrained air voids can be clearly seen. Right: Close view of a fracture surface treated with phenolphthalein $\mathrm{pH}$ indicator solution. Non-carbonated concrete is stained magenta. A cast surface is at the top of the photo. Scale at left is marked in millimeter increments.

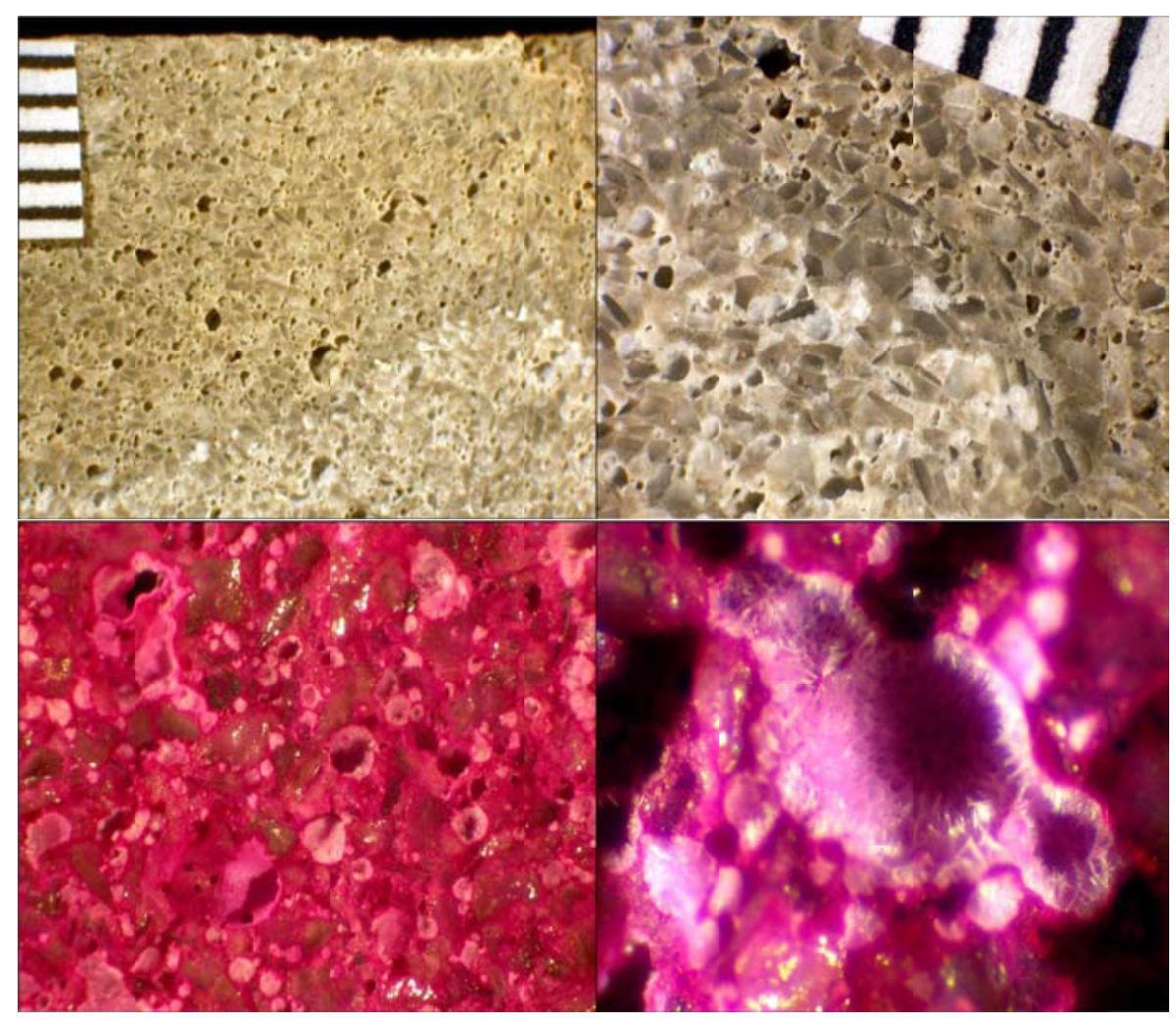

Figure 4.3. Top left: Lapped surface of CS-I-7\%. The top surface of the cast specimen is at the top of the photo. Note concrete color change and abundance of white deposits in the bottom portion of the photo. Scale at left is marked in millimeter increments. Top right: Closer view of concrete and air voids lined with ettringite deposits. Scale is marked in millimeter increments. Bottom left: Fracture surface of the interior portion of CS-I-7\% after treatment with phenolphthalein $\mathrm{pH}$ indicator solution. No concrete carbonation is observed. Bottom right: Closer view of ettringite needles lining air voids in the interior of the monolith. 
The concrete monolith hydration characteristics are normal. Partly hydrated cement grains are coated with transparent, colorless hydration rims. The level of fly ash replacement/substitution is moderate to high, based on the relative proportions of unhydrated and partly hydrated cement and residual fly ash. Portlandite (calcium hydroxide) is relatively abundant. The crystals are small and uniformly distributed. The concrete is air entrained with an estimated 5 to 7 percent small, spherical air voids; clustering of the voids is common. No secondary precipitate was observed. The concrete volume is estimated at 30 to 35 percent, interpreted water-cementitious materials ratio is 0.47 to 0.52 (Figure $4.4 \mathrm{a}$ and Table 4.4).

The outer concrete surfaces are carbonated (fine-grained, impure calcium carbonate) to an average depth of 2 to $4 \mathrm{~mm}$ (Figure 4.4b). Small patches of similar carbonated paste are present throughout the body of the sample. No significant cracks or micro-cracks are observed (Figure 4.4 and Table 4.4).

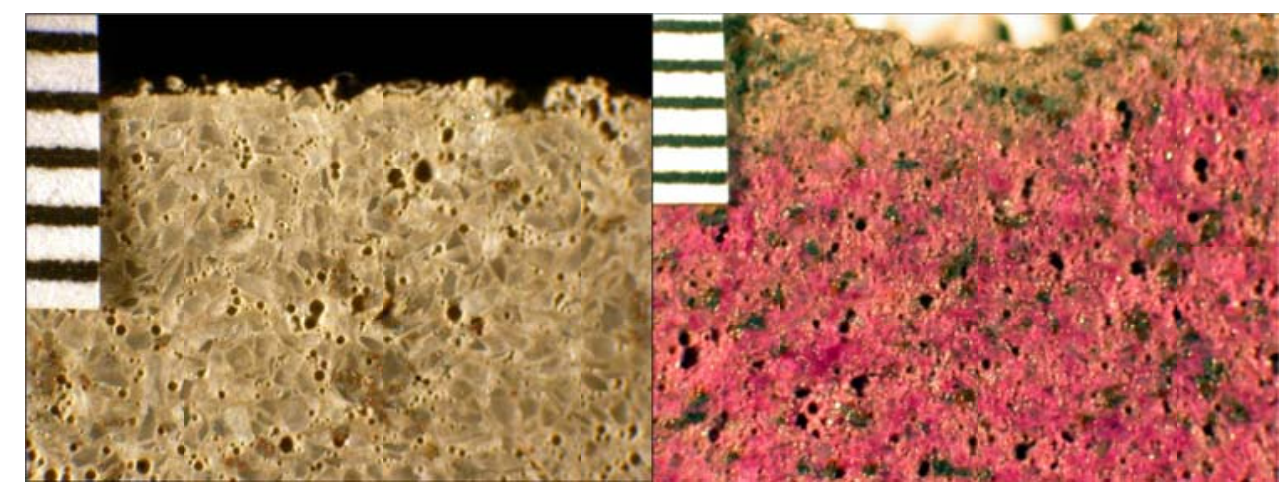

Figure 4.4. Left: Lapped surface of CS-III-7\%. The top surface shown is a struck surface. Air voids are non-uniformly distributed. Metallic aggregates are somewhat corroded. Right: Close view of a fracture surface treated with phenolphthalein $\mathrm{pH}$ indicator solution. Mottled pink-andmagenta stain is indicative of patchy carbonation. The top surface of the sample is at the top of the photo. Scale at left is marked in millimeter increments.

Petrographic results indicated that:

1. Concrete monoliths CS-II-4\% and CS-IV-4\%, which were not subjected to carbonation via supercritical fluid, displayed carbonation to a depth of $0.4 \mathrm{~mm}$ on the surface and 1 to $2 \mathrm{~mm}$ at the concrete-soil interface. $0.4 \mathrm{~mm}$ carbonation on the monolith surface may have occurred as a result of preparing the cores and allowing them to set under ambient conditions for 2 years prior to being sealed in the half-cell columns. However, deeper carbonation at the concrete-soil interface is believed to be a result of natural carbonation from contact with the sediment.

2. Concrete monoliths CS-I-7\% and CS-III-7\% were carbonated using supercritical fluid prior to being sealed in the half-cell columns; the extent of carbonation was observed to range from 2 to 8 $\mathrm{mm}$ for the two monoliths.

3. No micro-cracking was evident in any of the concrete monoliths; however, petrographic microscopy would only be able to identify cracks with a width ranging from 8 to $10 \mu \mathrm{m}$. Pending a more detailed scanning electron microscopy analysis, it is believed that micro-cracks, particularly within the carbonated regions, will be clearly visible. 
Table 4.4. Summary of petrographic observations for concrete Monoliths

\begin{tabular}{|c|c|c|c|c|c|c|}
\hline Sample & Carbonation & Aggregates & Monolith & $\begin{array}{c}\text { Interface } \\
\text { Carbonation } \\
\text { Depth, mm }\end{array}$ & $\begin{array}{c}\text { Secondary } \\
\text { Deposits }\end{array}$ & $\begin{array}{c}\text { Estimated Air } \\
\text { Content }\end{array}$ \\
\hline CS-II-4\% & $\begin{array}{l}2 \text { mm at top } \\
\text { of sample; } \\
\text { incipient on } \\
\text { remaining } \\
\text { cast surfaces }\end{array}$ & $\begin{array}{l}\text { Manufactured } \\
\text { sand }\end{array}$ & $\begin{array}{l}\text { Light beige-gray. } \\
\text { Moderately hard. } \\
\text { Portland cement } \\
\text { and fly ash. }\end{array}$ & 2 & $\begin{array}{l}\text { Ettringite in } \\
\text { voids in outer } 1 \\
\mathrm{~mm}\end{array}$ & $\begin{array}{l}6 \text { to } 8 \text { percent } \\
\text { small } \\
\text { spherical, } \\
\text { clustered } \\
\text { voids }\end{array}$ \\
\hline CS-IV-4\% & $\begin{array}{l}1 \text { to } 2 \mathrm{~mm} \text { on } \\
\text { top surface; } \\
\text { incipient on } \\
\text { remaining } \\
\text { cast surfaces }\end{array}$ & $\begin{array}{l}\text { Manufactured } \\
\text { sand and } 25 \text { to } \\
35 \text { percent } \\
\text { metallic } \\
\text { fragments }\end{array}$ & $\begin{array}{l}\text { Medium beige- } \\
\text { gray. Moderately } \\
\text { hard. Portland } \\
\text { cement and fly ash. }\end{array}$ & 1 to 2 & None observed & $\begin{array}{l}5 \text { to } 7 \text { percent } \\
\text { small } \\
\text { spherical, } \\
\text { clustered } \\
\text { voids }\end{array}$ \\
\hline CS-I-7\% & $\begin{array}{l}\text { Uneven, } 6 \text { to } \\
8 \mathrm{~mm} \text { from } \\
\text { outside } \\
\text { surfaces }\end{array}$ & $\begin{array}{l}\text { Manufactured } \\
\text { sand }\end{array}$ & $\begin{array}{l}\text { Medium beige- } \\
\text { gray. Moderately } \\
\text { hard. Portland } \\
\text { cement and fly ash. }\end{array}$ & 5 to 8 & $\begin{array}{l}\text { Abundant } \\
\text { deposits of } \\
\text { Ettringite in } \\
\text { voids in interior } \\
\text { portion of } \\
\text { sample }\end{array}$ & $\begin{array}{l}7 \text { to } 9 \text { percent } \\
\text { small } \\
\text { spherical, } \\
\text { clustered and } \\
\text { coalesced air } \\
\text { voids }\end{array}$ \\
\hline CS-III-7\% & $\begin{array}{l}\text { Uneven, } 2 \text { to } \\
4 \text { mm from } \\
\text { outer } \\
\text { surfaces. } \\
\text { Patchy in } \\
\text { body. }\end{array}$ & $\begin{array}{l}\text { Manufactured } \\
\text { sand and } 30 \text { to } \\
40 \text { percent } \\
\text { metallic } \\
\text { fragments }\end{array}$ & $\begin{array}{l}\text { Mottled medium } \\
\text { and dark beige- } \\
\text { gray. Moderately } \\
\text { hard. Portland } \\
\text { cement and fly ash. }\end{array}$ & 2 to 4 & None observed & $\begin{array}{l}6 \text { to } 8 \text { percent } \\
\text { small } \\
\text { spherical } \\
\text { voids }\end{array}$ \\
\hline
\end{tabular}

In summary:

- Specimens of historic above-ground, cored concrete specimens showed increased depth of carbonation with age. Depths of carbonation of $1-10 \mathrm{~mm}, 2-8 \mathrm{~mm}$ and $48-53 \mathrm{~mm}$ were measured for concrete specimens that were 14,28, and 57 year old respectively.

- Use of supercritical carbon dioxide generated $1-8 \mathrm{~mm}$ of carbonation; however, petrographic examination revealed cracks ranging $8-10 \mu \mathrm{m}$ in width within the carbonated region.

- All concrete cores buried in samples of vadose zone sediments $(4,7$, and $15 \%$ moisture content) carbonated on average to a depth of $0.3 \mathrm{~mm}$ in about 6 months. 


\subsection{Half-Cell Diffusion Test Methods}

Diffusion tests were conducted by using cylindrical cells consisting of a contaminant-spiked half cell in contact with unspiked cylindrical half cells. These tests are described in the following sections.

\subsection{Soil-Soil Diffusion Tests}

This experiment consisted of half cells ( $\sim 4-\mathrm{cm}$ diameter and $\sim 39-\mathrm{cm}$ long) of Trench 8 soil with hot side ( $\sim 18$ to $21 \mathrm{~cm}$ long) sediment-spiked stable iodide and technetium- 99 . The cold side ( $\sim 20$ to $22 \mathrm{~cm}$ long) contained the same soil that was unspiked. The Trench 8 soil is a medium coarse sand that was obtained from the sidewall of W-5 burial ground located in the Hanford Site. The physical, chemical, and the mineralogical properties of this soil have been characterized by Serne et al. (1993). Quantities of soil with appropriate moisture contents were packed into plastic cylinders to form these half cells. Before sampling, these plastic cylinders containing the soil-soil half cells were frozen with dry ice to facilitate the extrusion and slicing of low moisture soil cores. Sampling was conducted at appropriate time intervals by freezing the cells in dry ice and extruding and taking transverse sections of the sediment at about 0.5 $\mathrm{cm}$ intervals for the first 4 to $6 \mathrm{~cm}$ from the interface and at $1-\mathrm{cm}$ intervals for the remaining part of the half cell (Figure 5.1). The soil samples were weighed and extracted with either nitric acid or deionized distilled water, and the extracts were analyzed for iodide and technetium-99 using ICP-MS.

\subsection{Concrete-Soil Diffusion Tests}

The objective of this half-cell test was to examine the rate of diffusion of key, long-lived, mobile contaminants in unsaturated Hanford Site sediment in contact with a spiked concrete monolith. This experiment was conducted using a half cell of Trench 8 soil ( 4-cm diameter and $\sim 20-\mathrm{cm}$ long) in contact with a concrete monolith ( $\sim 4-\mathrm{cm}$ diameter and $\sim 4-\mathrm{cm}$ long) spiked with iodine-125, stable iodine, and technetium-99. The concrete monolith was prepared and radionuclides were first added to the water and then mixed into the dry ingredients. Sampling was conducted at appropriate time intervals by freezing the soil half-cell cells in dry ice and extruding and taking transverse sections of the sediment at about $0.5-\mathrm{cm}$ intervals for the first 4 to $6 \mathrm{~cm}$ from the interface and at 1-cm intervals for the remaining part of the half cell. The soil samples were weighed and extracted with either nitric acid or deionized distilled water, and the extracts were analyzed for stable iodide and technetium-99 using ICP-MS. 

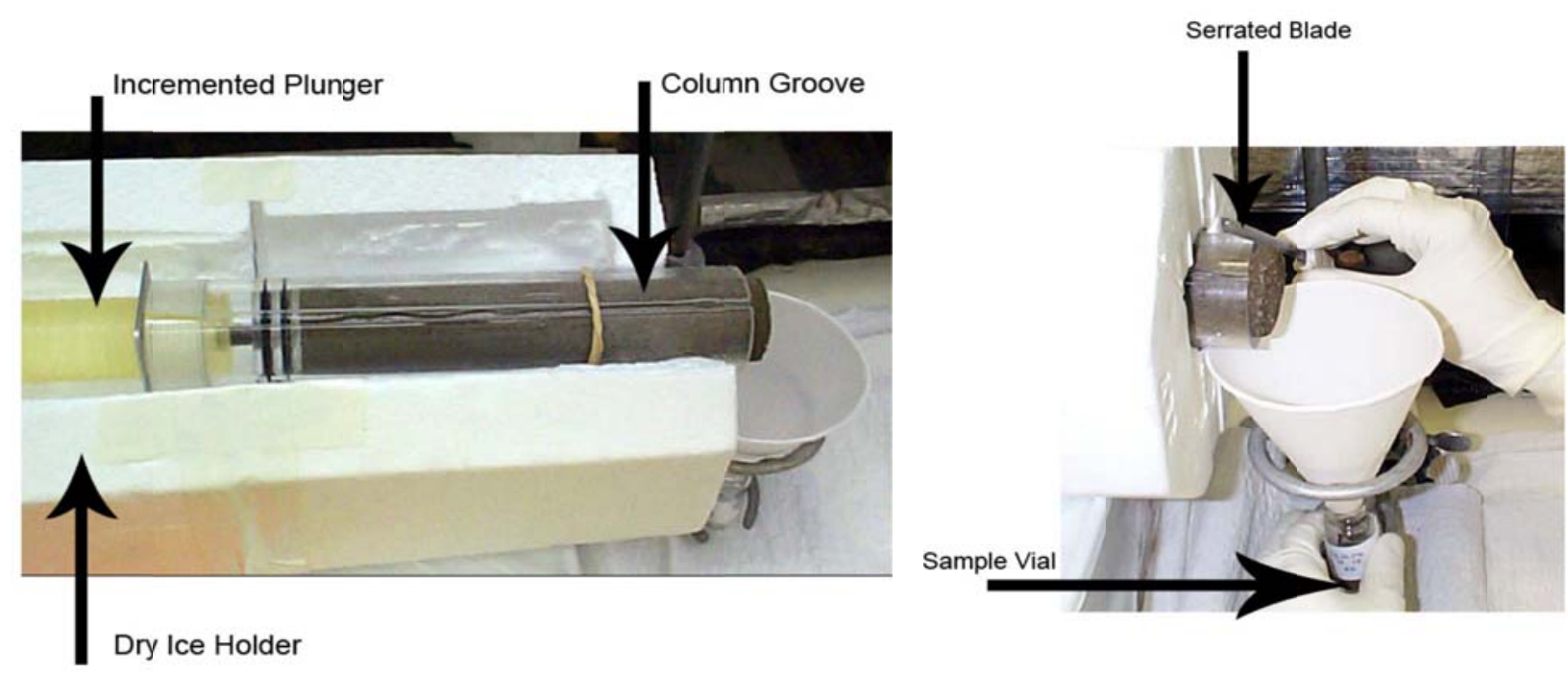

Figure 5.1. Left: Mechanism for soil sampling from a diffusion half cell; Right: soil sampling from a diffusion half cell

\subsection{Soil-Concrete Diffusion Tests}

The objective of this half-cell test was to examine the rate of diffusion of key, long-lived, mobile contaminants in concrete monoliths in contact with unsaturated spiked Hanford Site sediment half cells. This experiment was conducted using a half cell of Trench 8 soil ( 4-cm diameter and $\sim 20-\mathrm{cm}$ long) in contact with a concrete monolith ( $\sim 4-\mathrm{cm}$ diameter and $\sim 4-\mathrm{cm}$ long) spiked with iodine-125, stable iodine, technetium-99. Experiments were conducted to examine the effect of known quantities of metallic iron additions and carbonation of concrete half cells on diffusion of contaminants in concrete. At the end of the experimental period, the diffusion profile in a concrete half cell was determined by dry-slicing the cell with a Buehler slow-speed circular saw fitted with a diamond blade. The resulting thin slices were then crushed and extracted with deionized distilled water and the resulting solutions were analyzed for concentrations of contaminant of interest.

\subsection{Diffusion Coefficient Calculations}

The radionuclide diffusivity is defined by Fick's equation as

$$
J=-D_{w} d_{w} / d x
$$

where, $\mathrm{J}=$ flux of radionuclide at a given point, $\mathrm{D}_{\mathrm{w}}=$ the diffusivity of water-based radionuclide concentration, and $\mathrm{C}_{\mathrm{w}}=$ the radionuclide concentration in the pore water.

Ignoring the possibility that radionuclides might be present in the air within the unsaturated sediment, and recognizing that in the case of a two-phase system (water and soil), Equation 5.1 can be used in performing a mass balance over a small volume leading to the equation (Crank 1975)

$$
\mathrm{dC}_{\mathrm{w}} / \mathrm{dt}=\mathrm{D}_{\mathrm{w}} / \theta *\left(\mathrm{~d}^{2} \mathrm{C}_{\mathrm{w}} / \mathrm{dx}^{2}\right)
$$


where $\theta=$ the volume fraction water in the soil's pore space. However, the slope on the probit plot provides the diffusivity that solves the equation for diffusion in a homogeneous single phase medium,

$$
\mathrm{dC} / \mathrm{dt}=\mathrm{D}^{*}\left(\mathrm{~d}^{2} \mathrm{C} / \mathrm{dx}^{2}\right)
$$

The solution for this diffusion equation is provided by

$$
\mathrm{C} / \mathrm{C}_{0}=1 / 2 \operatorname{erfc}(\mathrm{x} / \sqrt{ } 4 \mathrm{Dt})
$$

where $\mathrm{C} / \mathrm{C}_{0}$ is the normalized concentration, and erfe is the error function (Crank 1975). The diffusivities in the soil were calculated using a probit analysis approach. The details of the probit analysis are provided in Finney (1971). This technique allows the transformation of a sigmoid curve of concentrations, normalized with respect to the initial concentration $\left(\mathrm{C}_{0}\right)$ as a function of diffusion distance $(\mathrm{x})$ produced in a half-cell diffusion experiment to a linear plot. The transformed equation is,

$$
\operatorname{Probit}(\mathrm{p})=\Phi^{-1}(\mathrm{p})=\mathrm{a}-\mathrm{x} / \sqrt{ } 2 \mathrm{Dt}
$$

When probit transform of $\mathrm{C} / \mathrm{C}_{0}$ is plotted against $\mathrm{x}$, the resulting slope $(\mathrm{b}=1 / \sqrt{2} \mathrm{Dt})$ can used to calculate the diffusivity (D) as $D=1 /\left(2 b^{2} t\right)$, where $t$ is the sampling time. This approach has been used previously to determine diffusivity in half-cell diffusion experiments (Brown et al. 1964. Lamar 1989). The diffusion coefficient $D_{w}$ that was calculated from the $\mathrm{D}$ obtained from the probit plot based on concentrations in the pore water must then be multiplied by $\theta$.

In a diffusion test where one boundary can be represented by a constant concentration, the concentration profile that develops is one-half of the normal sigmoid curve produced in the half-cell diffusion experiment. Thus, to apply the probit transformation, the concentrations are normalized by dividing by $2 * \mathrm{C}_{\mathrm{i}}$, where $\mathrm{C}_{\mathrm{i}}$ is the concentration at the constant concentration interface. This approach has been used to model diffusion from a non-depleting reservoir into asphalt (Martin et al. 1984).

The configuration of concrete-soil experiments had the soil in a half-cell arrangement with a dissimilar material (hardened concrete) containing the radionuclide spike. In the case of diffusion occurring between two dissimilar media, one of which is spiked and both of which are semi-infinite in dimension from the interface, the concentration at the interface will quickly reach and remain at a constant concentration as the diffusion proceeds (Crank 1975). Because of this result, the problem is mathematically the same as the case where a boundary is held at a constant concentration and the data can be normalized by dividing by $2 * \mathrm{C}_{\mathrm{i}}$, where $\mathrm{C}_{\mathrm{i}}$ is the concentration at the interface. However, because the concentration $\mathrm{C}_{\mathrm{i}}$ at the interface of the two dissimilar materials is not known, the concentration in the soil slice nearest the interface is used to approximate this value. This approximation introduces some bias in the calculated diffusivity because the concentration profile averaged over the first soil slice is systematically lower than the concentration at the interface of the first soil slice with the spiked mortar. The extent of the error is estimated to be about $12 \%$ from the concentration profile data of Crane et al. (1992). We assumed that the relative errors for the other tests were similar. This error magnitude is considered acceptable relative to the variance in the diffusivity values for all the tests.

In the early set of concrete-soil experiments, the diffusivity coefficients in concrete were calculated using soil diffusivity coefficients derived from probit plots. Also, a second set of concrete diffusivity coefficients were calculated by using soil diffusivity coefficients determined from probit plots of soil-soil 
half-cell experiments and the interfacial concentrations from the soil half cells of concrete-soil half-cell experiments.

Due to the difficulty involved in sampling the first $0.5-\mathrm{cm}$ soil slice at the interface, the accuracy of concentration measurements in this soil slice is less reliable than the measurements made on other slices of the soil half cell. Because the calculated concrete diffusivity values are sensitive to the measured concentrations of the diffusing radionuclide in the soil at the soil-concrete interface, a second approach was used to calculate the diffusivity values. This profile-matching approach consisted of using calculated soil diffusivities for a radionuclide from the soil-soil half-cell experiment to calculate diffusion profiles for a range of assumed interface concentrations in the concrete-soil half-cell experiments. Based on the best qualitative matching of the actual concentration profile with the calculated diffusion profiles, the concentration of the radionuclide at the interface was estimated. This estimated interface concentration and soil diffusivity was then used to estimate a concrete diffusivity value required to maintain the estimated interface concentration in concrete.

In later experiments, the diffusion profile in a concrete half cell was determined by dry-slicing the cell with a circular diamond saw. The resulting thin slices were then crushed and extracted with deionized distilled water and the resulting solutions were analyzed for concentrations of the contaminant of interest. 


\subsection{Diffusion of lodine and Technetium-99 in Soil-Soil and Concrete-Soil Half Cells}

A set of soil-soil and concrete-soil half cell experiments were conducted to elucidate the diffusion of iodine and technetium in soil in contact with spiked soil and spiked concrete half cells.

\subsection{Materials and Methods}

Soil-soil diffusion tests were conducted using cells $(4.13 \mathrm{~cm}$ diameter) consisting of a hot side ( $\sim 18$ to $21 \mathrm{~cm}$ long) sediment half cell spiked with stable iodide, and ${ }^{99} \mathrm{Tc}$. The cold side of the half cell ( $\sim 20$ to $22 \mathrm{~cm}$ long) contained the same soil unspiked. The soil used in these experiments is a medium coarse sand that was obtained from the sidewall of a trench located in the Hanford Site. Quantities of soil with appropriate moisture contents ( $\sim \%$ and $\sim 7 \%$ by weight) were packed into plastic cylinders to form these half cells. The characteristics of these half cells, including the dimensions, bulk densities, moisture contents, and spike concentrations are listed in Table 6.1.

The concrete-soil diffusion tests were conducted using half cells of the same Hanford Site soil ( 4-cm diameter and $\sim 20-\mathrm{cm}$ long) in contact with a concrete monolith ( $\sim 4-\mathrm{cm}$ diameter and $\sim 4-\mathrm{cm}$ long) spiked with stable iodine, and ${ }^{99} \mathrm{Tc}$. The characteristics of these half cells, including the dimensions, bulk densities, and moisture contents are listed in Table 6.1. Concrete half cells were prepared as described in the previous section (Section 5.0). The spike consisting of $\sim 460 \mathrm{mg} / \mathrm{kg}$ of stable iodide and $\sim 30 \mathrm{nCi} / \mathrm{kg}$ of ${ }^{99} \mathrm{Tc}$ was added to the water and then mixed into the dry ingredients. Sampling was conducted at $64-$ and 169-day intervals by freezing the cells in dry ice and extruding and taking transverse sections of the sediment at about $0.5-\mathrm{cm}$ intervals for the first 4 to $6 \mathrm{~cm}$ from the interface, and at $1-\mathrm{cm}$ intervals for the remainder of the half cell. The soil samples at the end of the experiments were weighed and extracted with either $0.1 \mathrm{M}$ nitric acid or deionized distilled water, and the extracts were analyzed for stable iodide, and ${ }^{99} \mathrm{Tc}$.

Table 6.1. Characteristics of the Concrete-Soil and Soil-Soil Half Cells

\begin{tabular}{|c|c|c|c|c|c|c|c|c|}
\hline \multirow[b]{2}{*}{ Cell } & \multicolumn{3}{|c|}{ Length of Half Cell $(\mathrm{cm})$} & \multicolumn{3}{|c|}{ Bulk Density $\left(\mathrm{g} / \mathrm{cm}^{3}\right)$} & \multirow{2}{*}{$\begin{array}{c}\text { Initial Soil } \\
\text { Water Content } \\
(\%)^{*}\end{array}$} & \multirow{2}{*}{$\begin{array}{c}\text { Duration } \\
\text { (days) }\end{array}$} \\
\hline & Concrete & Hot Soil & Cold Soil & Concrete & Hot Soil & Cold Soil & & \\
\hline Soil-soil & & 18.2 & 19.7 & & $1.41^{\mathrm{a}}$ & 1.53 & 7.17 & 64 \\
\hline Soil-soil & & 17.5 & 20.5 & & $1.45^{\mathrm{a}}$ & 1.62 & 7.17 & 169 \\
\hline Soil-soil & & 21.1 & 22.0 & & $1.32^{\mathrm{b}}$ & 1.40 & 4.10 & 64 \\
\hline Soil-soil & & 18.0 & 20.7 & & $1.50^{\mathrm{b}}$ & 1.53 & 4.10 & 169 \\
\hline Concrete-soil & 4.3 & & 19.6 & 2.23 & & 1.41 & 4.10 & 64 \\
\hline Concrete-soil & 4.2 & & 19.5 & 2.21 & & 1.42 & 4.10 & 169 \\
\hline Concrete-soil & 4.2 & & 20.9 & 2.25 & & 1.42 & 7.17 & 64 \\
\hline Concrete-soil & 4.2 & & 21.5 & 2.21 & & 1.37 & 7.17 & 169 \\
\hline
\end{tabular}

The diameter of cells was $4.13 \mathrm{~cm}$. Spike: ${ }^{\mathrm{a}} 640 \mu \mathrm{g} / \mathrm{g}$ of I, $14.8 \mathrm{nCi} / \mathrm{g}$ of ${ }^{99} \mathrm{Tc},{ }^{\mathrm{b}} 574 \mu \mathrm{g} / \mathrm{g}$ of I, $10.6 \mathrm{nCi} / \mathrm{g}$ of ${ }^{99} \mathrm{Tc}$. The concrete monoliths were aged for 28 days before half cells were packed. 


\subsection{Results and Discussion}

\subsubsection{Soil-Soil Diffusion Test}

The nitric acid extraction of the 64-day samples recovered $80 \%$ of spiked ${ }^{99} \mathrm{Tc}$, whereas iodide concentrations could not be obtained because during the nitric acid extraction the iodide ions were oxidized to iodine and the iodine was lost through volatilization. The water extractions of the 169-day samples recovered $60 \%$ of both Tc and I. Therefore, the measured concentrations were corrected to reflect the actual concentrations of diffused Tc and I in the soil.

Typical normalized concentration profiles for iodide and ${ }^{99} \mathrm{Tc}$ from the soil-soil diffusion experiment conducted for 169 days at 7\% water content are shown in Figure 6.1. The corresponding probit plots for iodide and ${ }^{99} \mathrm{Tc}$ are shown in Figure 6.2. The 169-day normalized concentration profiles for iodide obtained from using deionized distilled water extraction showed well developed sigmoidal distributions of normalized concentrations (Figure 6.1). Similarly, the normalized concentrations in the 7\% water content soil-soil half cells for ${ }^{99} \mathrm{Tc}$ also exhibited a typical sigmoidal profile (Figure 6.1).

Typically, for most cases, the probit plots provided a very good fit to the data for both sides of the half cells (Figure 6.2). However, in a few cases, the probit plots yielded noticeably different slopes on the spike side when compared to the slopes on the initially cold side. In such cases, the probit plots of the cold side data containing more closely spaced concentration measurements were used to calculate the diffusivity coefficients.

The calculated diffusivity coefficients for iodide were $1.73 \times 10-8 \mathrm{~cm}^{2} / \mathrm{s}$ and $1.32 \times 10-7 \mathrm{~cm}^{2} / \mathrm{s}$ for soils at $4 \%$ and $7 \%$ moisture contents, respectively (see Table 6.2). These data indicated that iodide diffusivity is a function of soil moisture content and is about an order of magnitude slower at lower moisture content ( $\sim \%$ by weight). The diffusivity coefficients calculated for ${ }^{99} \mathrm{Tc}$ (Table 6.2 ) were on average $1.45 \times 10-8 \mathrm{~cm}^{2} / \mathrm{s}$ ( $\sim 4 \%$ moisture content) and $1.11 \times 10-7 \mathrm{~cm}^{2} / \mathrm{s}(\sim 7 \%$ moisture content $)$, respectively.

Table 6.2. Calculated soil diffusion parameters for iodide and ${ }^{99} \mathrm{Tc}$ from soil-soil half-cell experiments

\begin{tabular}{cccc}
\hline Nuclide & $\begin{array}{c}\text { Initial Water } \\
\text { content }(\%)\end{array}$ & $\begin{array}{c}\text { Time } \\
\text { (Days) }\end{array}$ & $\begin{array}{c}\text { Diffusivity in Soil } \\
\left(\mathrm{cm}^{2} / \mathrm{s}\right)\end{array}$ \\
\hline $\mathrm{I}$ & 4 & 169 & $1.73 \times 10^{-8(\mathrm{a})}$ \\
$\mathrm{I}$ & 7 & 169 & $1.32 \times 10^{-7}$ (a) \\
${ }^{99} \mathrm{Tc}$ & 4 & 64 & $1.59 \times 10^{-8}$ (b) \\
${ }^{99} \mathrm{Tc}$ & 4 & 169 & $1.31 \times 10^{-8}$ (b) \\
${ }^{99} \mathrm{Tc}$ & 7 & 64 & $1.33 \times 10^{-7}$ (b) \\
${ }^{99} \mathrm{Tc}$ & 7 & 169 & $8.96 \times 10^{-8(\mathrm{a})}$ \\
\hline
\end{tabular}

Calculated from fitting (a) cold-side diffusion profile,

(b) both hot- and cold-side diffusion profiles 
These values indicated that soil moisture content also has a significant impact on ${ }^{99} \mathrm{Tc}$ diffusivity because at lower moisture content $(\sim 4 \%)$ the ion diffusion was about an order of magnitude lower than values obtained at higher moisture content ( $7 \%)$. The diffusivity values obtained from these experiments for iodide and ${ }^{99} \mathrm{Tc}$ are similar in magnitude at each water content, indicating that these ions may have similar diffusion mechanisms in unsaturated coarse textured soils.

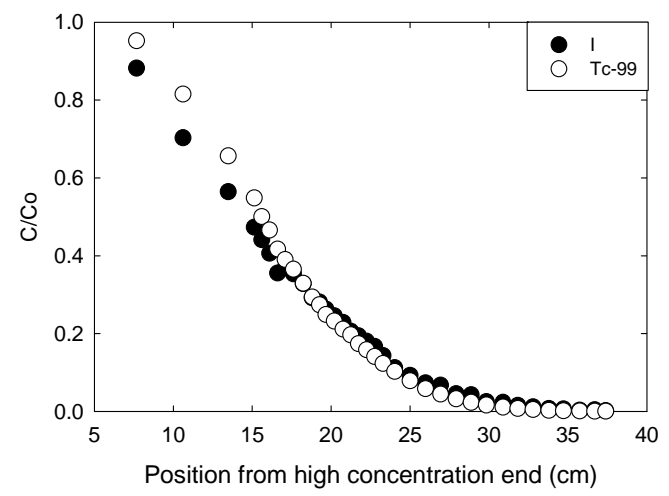

Figure 6.1. Normalized concentration profiles for iodide and ${ }^{99} \mathrm{Tc}$ in $7 \%$ water content soil-soil cells at the end of 169 days

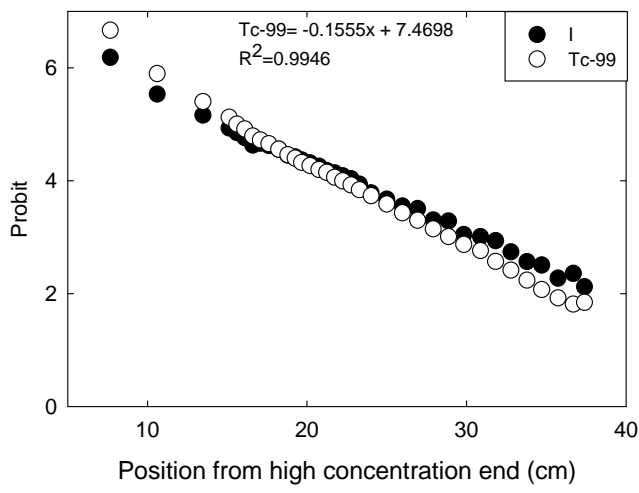

Figure 6.2. Probit plots for iodide and ${ }^{99} \mathrm{Tc}$ in $7 \%$ water content soil-soil cells at the end of 169 days

\subsubsection{Concrete-Soil Diffusion Test}

The normalized concentration profiles for iodide and ${ }^{99} \mathrm{Tc}$ from concrete-soil diffusion experiments are shown in Figure 6.3. Typical probit plots for iodide and ${ }^{99} \mathrm{Tc}$ are shown in Figure 6.4 and the results are summarized in Table 6.3.

As indicated earlier, the iodide concentrations for the 64-day sampling period could not be determined due to oxidation of iodide to iodine during nitric acid extraction and the loss of iodine thorough volatilization. For some unknown reason, the 169-day normalized profile for iodide in the soil half cell (at 7\% moisture content) exhibited anomalous concentrations in the first $4 \mathrm{~cm}$ of the interfacial region (Figure 6.3). In contrast, the 64- and 169-day data for ${ }^{99} \mathrm{Tc}$ showed predictable diffusion profiles that indicated relatively constant interfacial concentrations that were independent of sampling times. 


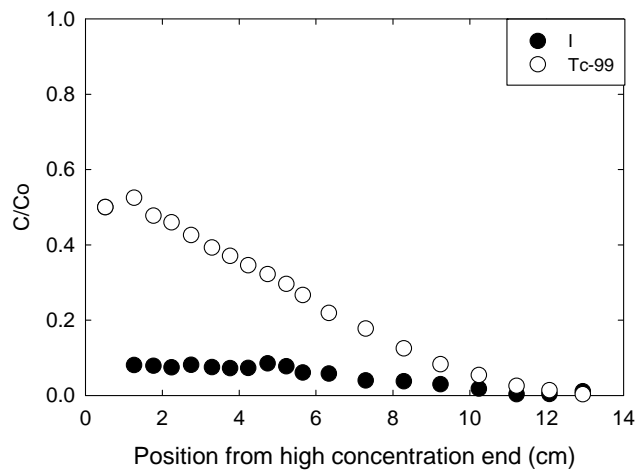

Figure 6.3. Normalized concentration profiles for I and Tc in 7\% water concrete-soil half-cells at the end of 169 days

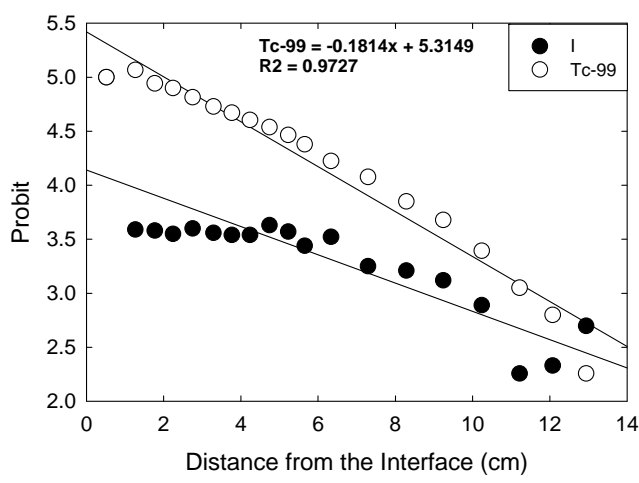

Figure 6.4. Probit plots for I and Tc in 7\% water content concrete-soil half- cells at the end of 169 days

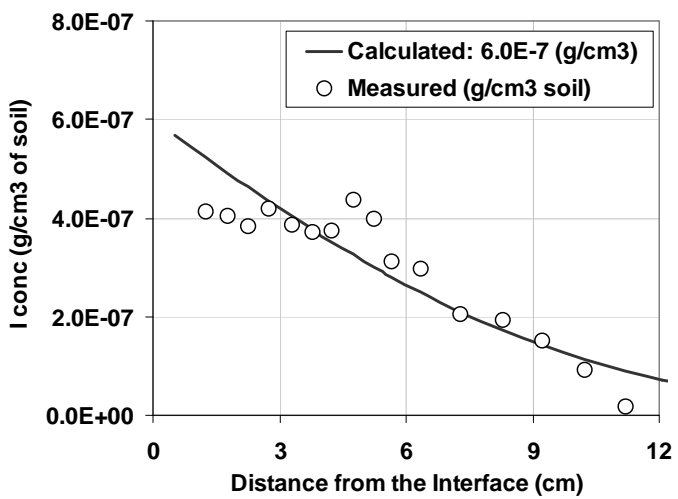

Figure 6.5. Calculated and measured concentration profiles for iodide in concrete-soil half cell (7\% water content, 169 days) 


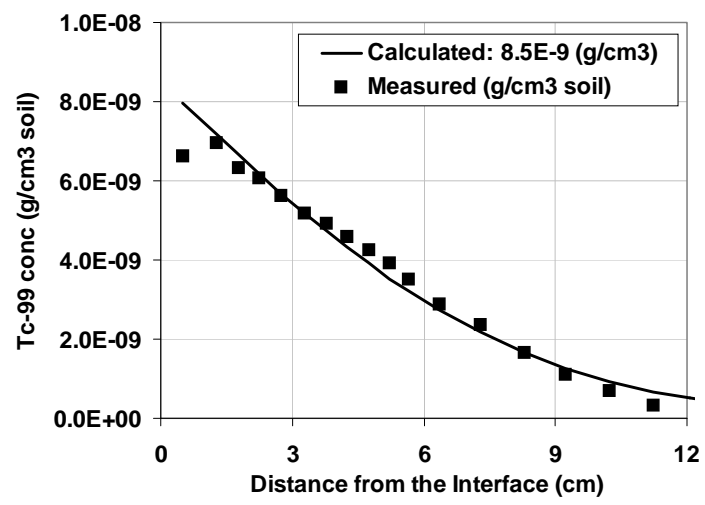

Figure 6.6. Calculated and measured concentration profiles for ${ }^{99} \mathrm{Tc}$ in concrete-soil half cell (7\% water content, 169 days)

Table 6.3. Calculated concrete diffusion parameters for iodide and ${ }^{99} \mathrm{Tc}$

\begin{tabular}{|c|c|c|c|c|c|c|c|}
\hline \multirow{2}{*}{\multicolumn{2}{|c|}{ Nuclide }} & \multirow[b]{2}{*}{$\begin{array}{c}\text { Water } \\
\text { content }(\%)\end{array}$} & \multirow[b]{2}{*}{$\begin{array}{l}\text { Time } \\
\text { (Days) }\end{array}$} & \multicolumn{4}{|c|}{ Diffusivity in concrete $\left(\mathrm{cm}^{2} / \mathrm{s}\right)$} \\
\hline & & & & Probit ${ }^{\text {a) }}$ & Probit ${ }^{(b)}$ & $\begin{array}{c}\text { Profile } \\
\text { Matching }^{(\mathrm{c})}\end{array}$ & Average \\
\hline & I & 4 & 169 & $7.90 \times 10^{-15}$ & $3.35 \times 10^{-14}$ & -- & $2.07 \pm 1.81 \times 10^{-14}$ \\
\hline & I & 7 & 169 & -- & -- & $1.31 \times 10^{-12}$ & $1.31 \times 10^{-12}$ \\
\hline & ${ }^{99} \mathrm{Tc}$ & 4 & 64 & $5.70 \times 10^{-12}$ & $6.74 \times 10^{-12}$ & -- & $6.22 \pm 0.74 \times 10^{-12}$ \\
\hline & ${ }^{99} \mathrm{Tc}$ & 4 & 169 & $1.75 \times 10^{-13}$ & $3.14 \times 10^{-13}$ & $8.73 \times 10^{-13}$ & $4.54 \pm 3.69 \times 10^{-13}$ \\
\hline & ${ }^{99} \mathrm{Tc}$ & 7 & 64 & $2.04 \times 10^{-11}$ & $4.34 \times 10^{-11}$ & $6.35 \times 10^{-11}$ & $4.24 \pm 2.16 \times 10^{-11}$ \\
\hline & ${ }^{99} \mathrm{Tc}$ & 7 & 169 & $5.26 \times 10^{-12}$ & $7.11 \times 10^{-12}$ & $1.17 \times 10^{-11}$ & $8.02 \pm 3.32 \times 10^{-12}$ \\
\hline (a) & \multicolumn{7}{|c|}{$\begin{array}{l}\text { Calculated from the soil diffusivity values from probit plots of concrete-soil half-cell experiments and } \\
\text { measured interface concentrations. }\end{array}$} \\
\hline (b) & \multicolumn{7}{|c|}{$\begin{array}{l}\text { Calculated from soil diffusivity values from probit plots of soil-soil half-cell experiments and measured } \\
\text { interface concentrations from concrete-soil half-cell experiments. }\end{array}$} \\
\hline (c) & \multicolumn{7}{|c|}{$\begin{array}{l}\text { Calculated from interfacial concentrations derived from matching concentration profiles from concrete-soil } \\
\text { half-cell experiments with calculated concentrated profiles from 169-day soil diffusivities calculated from } \\
\text { soil-soil half-cell experiments. }\end{array}$} \\
\hline
\end{tabular}

For most cases, the probit plots provided a very good data fit except in a few cases where there were too few data points (64-day ${ }^{99} \mathrm{Tc}$ data for $\sim 4 \%$ of the half cell and 169-day iodide data shown in Figure $6.4)$.

Also listed are the concrete diffusivity values calculated from soil diffusivity coefficients determined from soil-soil half-cell experiments and the interfacial concentrations from the soil half cells of concretesoil half-cell experiments. The data showed that the concentrations in the first slice near the interface were consistently lower than in the second slice. Such anomalous concentrations at the interface were due to either interface sampling problems and/or the lower moisture content of the soil near the interface. Typical results of the profile-matching approach are shown in Figures 6.5 and 6.6, and the calculated diffusivities are listed in Table 6.3. Some of the data obtained at 4\% moisture content for the 169-day iodide and 64day ${ }^{99} \mathrm{Tc}$ samples (data not included) showed a poor fit with calculated concentration profiles due to a large scatter among a limited number of data points. Other concentration data that 
showed a relatively fair to good fit with calculated concentration profiles were used to estimate the interfacial concentrations and concrete diffusivity values. The concrete diffusivity values calculated using both the approaches are summarized in Table 6.3. The concrete diffusivity values for iodide ranged from $2.07 \times 10^{-14} \mathrm{~cm}^{2} / \mathrm{s}$ ( $\sim \%$ soil moisture content) to $1.31 \times 10^{-12} \mathrm{~cm}^{2} / \mathrm{s}$ (7\% soil moisture content), indicating that under unsaturated soil conditions, a small change ( $\sim 3 \%$ change $)$ in moisture content results in about a two orders of magnitude increase in diffusivity.

The concrete diffusivity of ${ }^{99} \mathrm{Tc}$ calculated for the 64 - day sampling period ranged from $6.22 \times 10^{-12}$ $\mathrm{cm}^{2} / \mathrm{s}$ ( $\sim 4 \%$ soil moisture content) to $4.24 \times 10^{-11} \mathrm{~cm}^{2} / \mathrm{s}$ (7\% soil moisture content), and for the 169-day sampling period ranged from $4.54 \times 10^{-13} \mathrm{~cm}^{2} / \mathrm{s}\left(\sim 4 \%\right.$ soil moisture content) to $8.02 \times 10^{-12} \mathrm{~cm}^{2} / \mathrm{s}(7 \%$ soil moisture content). These ranges of values indicated that, at fixed moisture content, ${ }^{99} \mathrm{Tc}$ transport out of concrete slowed by more than an order of magnitude between the two sampling periods (105 days). For each sampling period, the diffusivity of ${ }^{99} \mathrm{Tc}$ at higher moisture content $(\sim 7 \%)$ was about an order of magnitude higher than diffusivity at lower moisture content ( 4\%). For the same diffusion period (169 days), at both soil moisture contents, iodide seemed to diffuse more slowly than ${ }^{99} \mathrm{Tc}$. At lower moisture content ( 4\%), iodide diffused about 20 times more slowly than ${ }^{99} \mathrm{Tc}$, whereas at higher moisture content $(\sim 7 \%)$, iodide diffused only about 6 times slower than ${ }^{99} \mathrm{Tc}$.

Using these data, a range of concrete diffusivity values for iodide and ${ }^{99} \mathrm{Tc}$ were selected for use in performance assessment calculations (Table 6.3). Although, initially the spikes were added to the concrete in the form of pertechnetate and iodide, the redox speciation of these elements in concrete at the end of experiments were not determined. However, from the Eh-pH stability of iodine species (Pourbaix 1966), it is probable that iodide may have oxidized into iodate under the highly alkaline conditions that exist within concrete matrix. Thus, the concrete diffusivity values determined from these experiments may pertain to iodate species rather than iodide species. In comparison, the Eh-pH relationship for technetium indicates that the pertechnetate species are stable under highly alkaline conditions (Pourbaix 1966) therefore, the measured diffusivity values may reflect the diffusion of this species in concrete.

A literature review indicated that diffusivity data for these radionuclides are lacking for unsaturated coarse-textured soils. Therefore, the diffusivity data obtained in these experiments cannot be compared with data published for various soils under saturated conditions. Typically, studies of radionuclide diffusion in concrete have involved several techniques, such as through diffusion, in/out diffusion, and penetration profile methods (Atkinson and Nickerson 1988). All these techniques involve contacting concrete specimens with radionuclide-spiked solutions and monitoring the movement of radionuclides in/out or through the material. Therefore, the diffusivity values obtained from such experiments cannot be compared with the values obtained from our half-cell experiments in which the diffusion out of initially spiked concrete specimens and in to unsaturated soils was measured.

In Summary:

- Increasing moisture content from $4 \%$ to $7 \%$ increased the diffusivities of both ${ }^{125} \mathrm{I}$ and ${ }^{99} \mathrm{Tc}$ by about an order of magnitude.

- The diffusivity of ${ }^{125} \mathrm{I}$ increased from $1.7 \times 10^{-8} \mathrm{~cm}^{2} / \mathrm{s}$ in $4 \%$ initial moisture content soil to $1.3 \times 10^{-7}$ $\mathrm{cm}^{2} / \mathrm{s}$ in $7 \%$ initial moisture content soil. Similarly, the diffusivity of ${ }^{99} \mathrm{Tc}$ increased from $\sim 1.5 \times 10^{-8}$ $\mathrm{cm}^{2} / \mathrm{s}$ in $4 \%$ initial moisture content soil to $\sim 1.1 \times 10^{-7} \mathrm{~cm}^{2} / \mathrm{s}$ in $7 \%$ initial moisture content soil.

- The diffusivity in concrete calculated by concentration-profile fitting for the spiked soil half cell yielded a value of $1.31 \times 10^{-12} \mathrm{~cm}^{2} / \mathrm{s}$ for ${ }^{125} \mathrm{I}$ and values ranging from $4.54 \times 10^{-13} \mathrm{~cm}^{2} / \mathrm{s}$ to $4.54 \times 10^{-11}$ 
$\mathrm{cm}^{2} / \mathrm{s}{ }^{99} \mathrm{Tc}$, respectively. These values are considered to be approximations because the radionuclide concentrations in the concrete half cells were not measured directly. 



\subsection{Effect of Supercritical Carbonation and Metallic Iron Addition on I and Re Diffusion in Soils}

\subsection{Concrete-Soil Half Cells}

Diffusion tests were conducted to assess the effects of concrete carbonation and the inclusion of colloidal iron on the rate of diffusion of key, long-lived mobile contaminants iodine and rhenium (as a surrogate for Tc) in unsaturated Hanford Site sediments ( $\sim \%$ and $7 \%$ moisture content by weight) in contact with a spiked concrete monolith. The differences between this set of tests and the previously conducted tests were: 1$)$ the experiments were conducted for a longer period of time; 2$)$ iron fibers $(\sim 4 \%)$ were added to some of the concrete half cells to examine any effect Fe may have on diffusion; and 3) the effect of carbonation of spiked concrete half cells on diffusion of Re and I were studied. The details of the experimental set up have been previously described (Section 5.0). Concrete monoliths were prepared in two separate batches based on laboratoryscale specifications for the concrete.

One batch contained iron particles and the other batch did not contain any added iron. Stable iodine and rhenium were added to the water component and then mixed into the dry ingredients. Within the two batches of concrete, with iron and without iron, half the monoliths were carbonated using supercritical carbon dioxide. The resulting compositions consisted of 4 concrete specimens: 1) no iron, carbonated; 2) no iron, not carbonated; 3) iron, carbonated; and 4) iron, not carbonated.

The diffusion tests were conducted under unsaturated conditions at $4 \%$ and $7 \%$ (wt $\%$ ) moisture content. One concrete core of each composition was encased in a Schedule 40, $24 \mathrm{~cm}$ long, PVC pipe. The volume of each pipe was filled with Hanford Site sediment at 4\% or 7\% (wt $\%$ ) moisture content, respectively. The ends of each pipe were machined and fit with o-ring gaskets to ensure the test cells were sealed. The diffusion tests were allowed to set horizontally and undisturbed for a period of one year with periodic rotation of the cell by 90 degrees. Characteristics of the concrete-soil diffusion half cells are listed in Table 7.1

At the end of the experiments the sampling and analysis of the half cells were conducted as described previously. 
Table 7.1. Characteristics of the concrete-soil half cells

\begin{tabular}{|c|c|c|c|c|c|c|c|c|c|c|c|}
\hline Core ID & $\begin{array}{l}\text { Concrete } \\
\text { Treatment }\end{array}$ & $\begin{array}{l}\text { I Conc. } \\
\left(\mathrm{g} / \mathrm{cm}^{3}\right)\end{array}$ & $\begin{array}{l}\text { Re Conc. } \\
\left(\mathrm{g} / \mathrm{cm}^{3}\right)\end{array}$ & $\begin{array}{c}\text { Length } \\
\text { Concrete } \\
\text { Half } \\
\text { Cell } \\
(\mathrm{cm})\end{array}$ & $\begin{array}{c}\text { Volume } \\
\text { of } \\
\text { Concrete } \\
\text { Half Cell } \\
\left(\mathrm{cm}^{3}\right)\end{array}$ & $\begin{array}{c}\text { Concrete } \\
\text { Density } \\
\left(\mathrm{g} / \mathrm{cm}^{3}\right)\end{array}$ & $\begin{array}{l}\text { Length of } \\
\text { Soil Half } \\
\text { Cell }(\mathrm{cm})\end{array}$ & $\begin{array}{c}\text { Volume } \\
\text { of Soil } \\
\text { Half Cell } \\
\left(\mathrm{cm}^{3}\right)\end{array}$ & $\begin{array}{c}\text { Density } \\
\text { Soil } \\
\left(\mathrm{g} / \mathrm{cm}^{3}\right)\end{array}$ & $\begin{array}{c}\text { Soil } \\
\text { Moisture } \\
\text { Content } \\
(\%)\end{array}$ & $\begin{array}{c}\text { Test } \\
\text { Duration } \\
\text { (days) }\end{array}$ \\
\hline CS-I-4\% & $\begin{array}{l}\text { No iron, } \\
\text { carbonated }\end{array}$ & $1.21 \times 10^{-3}$ & $1.77 \times 10^{-3}$ & 4.20 & 109.08 & 1.87 & 32.30 & 719.7 & 1.54 & 4.2 & 357 \\
\hline CS-II-4\% & $\begin{array}{l}\text { No iron, not } \\
\text { carbonated }\end{array}$ & $1.17 \times 10^{-3}$ & $1.72 \times 10^{-3}$ & 4.35 & 109.66 & 1.82 & 32.15 & 715.6 & 1.56 & 4.2 & 357 \\
\hline CS-III-4\% & $\begin{array}{l}\text { Iron, } \\
\text { carbonated }\end{array}$ & $1.14 \times 10^{-3}$ & $1.68 \times 10^{-3}$ & 4.20 & 118.19 & 2.03 & 32.30 & 717.0 & 1.56 & 4.2 & 357 \\
\hline CS-IV-4\% & $\begin{array}{c}\text { Iron, not } \\
\text { carbonated }\end{array}$ & $1.15 \times 10^{-3}$ & $1.19 \times 10^{-3}$ & 4.25 & 120.76 & 2.05 & 32.25 & 715.6 & 1.53 & 4.2 & 357 \\
\hline CS-I-7\% & $\begin{array}{l}\text { No iron, } \\
\text { carbonated }\end{array}$ & $1.18 \times 10^{-3}$ & $1.73 \times 10^{-3}$ & 4.00 & 101.53 & 1.83 & 32.50 & 719.7 & 1.53 & 6.9 & 397 \\
\hline CS-II-7\% & $\begin{array}{l}\text { No iron, not } \\
\text { carbonated }\end{array}$ & $1.18 \times 10^{-3}$ & $1.73 \times 10^{-3}$ & 4.30 & 109.29 & 1.83 & 32.10 & 713.5 & 1.52 & 6.9 & 397 \\
\hline CS-III-7\% & $\begin{array}{c}\text { Iron, } \\
\text { carbonated }\end{array}$ & $1.17 \times 10^{-3}$ & $1.71 \times 10^{-3}$ & 4.20 & 120.72 & 2.07 & 32.50 & 721.2 & 1.55 & 6.9 & 397 \\
\hline CS-IV-7\% & $\begin{array}{c}\text { Iron, not } \\
\text { carbonated }\end{array}$ & $1.15 \times 10^{-3}$ & $1.69 \times 10^{-3}$ & 4.30 & 122.24 & 2.05 & 32.20 & 715.6 & 1.58 & 6.9 & 397 \\
\hline
\end{tabular}




\subsection{Results and Discussion}

The concentration profiles for iodine and rhenium from concrete-soil half-cell diffusion experiments are shown in Figure 7.1 and 7.2. The behavior of rhenium and iodine release was comparable within a given half-cell test. At $4 \%$ moisture content, concentration profiles of both rhenium and iodine rapidly decreased to zero within the first $5 \mathrm{~cm}$ of the soil half cell (Figure 7.1). Concentration profiles for iodine and rhenium in 7\% moisture content soil indicated that these elements had diffused deeper into the soil (Figure 7.2). A comparison of concentration profiles for sediments at $4 \%$ and $7 \%$ moisture content suggests the rate of diffusion increases with increasing moisture content.

The probit plots for the diffusion profiles are shown in Figures 7.3 and 7.4 and the calculated diffusivity values are listed in Table 7.2. The data indicated that moisture content had the most significant effect on the diffusivity of rhenium and iodine. These components diffused about an order of magnitude faster in soil with $7 \%$ moisture content as compared to the soil cells with $4 \%$ moisture content.

Soils in contact with carbonated concrete half cells exhibited on average slightly enhanced diffusivity of Re and I. This may be due to the development of micro-cracks in concrete half cells when subjected to supercritical carbonation (See Section 4.2) that may enhance the release of contaminants. The presence of a low concentration of iron fibers did not seem to significantly affect the diffusivity of either rhenium or iodine.

In summary:

- The diffusivity of Re and I in low moisture (4\%) soil ranged from $1.3-2.9 \times 10^{-9} \mathrm{~cm}^{2} / \mathrm{s}$ and $1.9 \times 10^{-9}-4.5 \times 10^{-8} \mathrm{~cm}^{2} / \mathrm{s}$ respectively.

- In higher moisture content soil (7\%) the diffusivities were about an order of magnitude higher for both $\operatorname{Re}\left(3.3-5.8 \times 10^{-8} \mathrm{~cm}^{2} / \mathrm{s}\right)$ and I $\left(3.9-6.3 \times 10^{-8} \mathrm{~cm}^{2} / \mathrm{s}\right)$.

- Micro-cracking of source concrete from supercritical carbonation on average appeared to enhance diffusivities of Re and I in soils.

- The presence of a low concentration of iron fibers did not seem to significantly affect the diffusivity of either rhenium or iodine. 

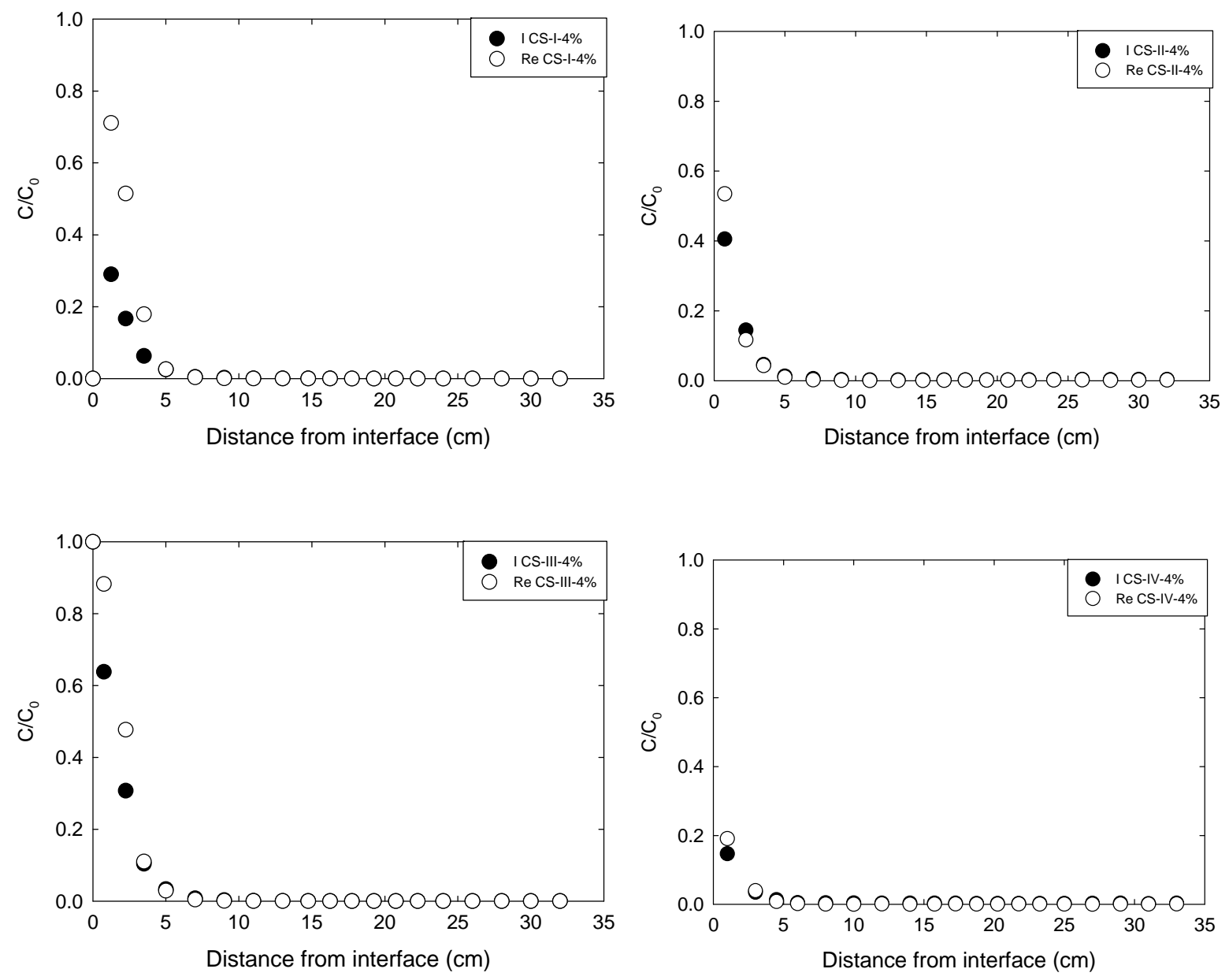

Figure 7.1. Concentration profiles of iodine and rhenium for soil half cells. Top left: $4 \%$ moisture content, no Fe, carbonated (CS-I-4); Top right: 4\% moisture content, no Fe, no carbonation (CS-II-4\%); Bottom left: 4\% moisture content, 4\% Fe, carbonated (CS-III-4\%); Bottom right: 4\% moisture content, $4 \% \mathrm{Fe}$, no carbonation (CS-I4-4\%). 

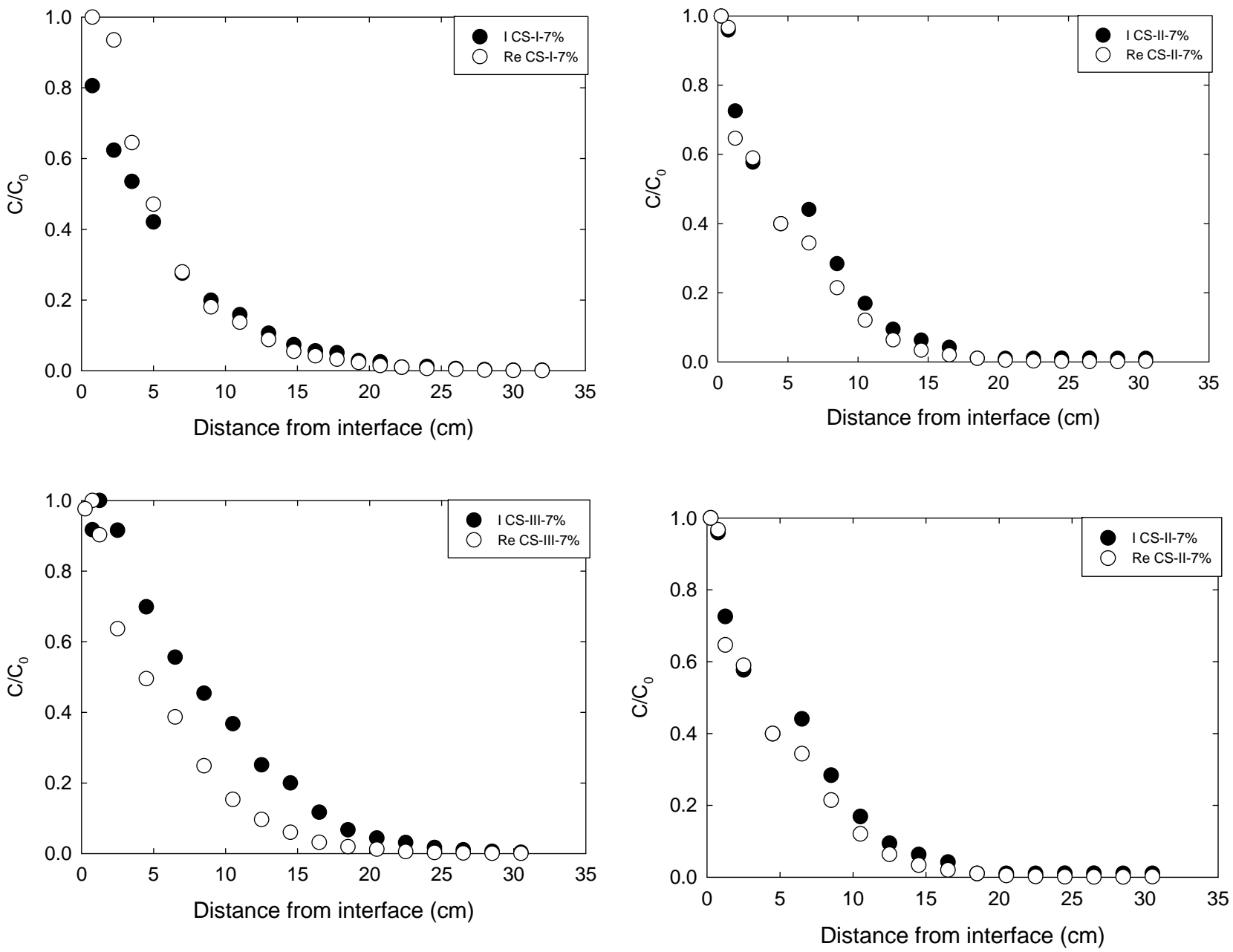

Figure 7.2. Concentration profiles of iodine and rhenium for soil half cells. Top left: 7\% moisture content, no Fe, carbonated (CS-I-4); Top right: 7\% moisture content, no Fe, no carbonation (CS-II-4); Bottom left: 7\% moisture content, 4\% Fe, carbonated (CS-III-4); Bottom right: $7 \%$ moisture content, $4 \% \mathrm{Fe}$, no carbonation (CS-IV-4). 

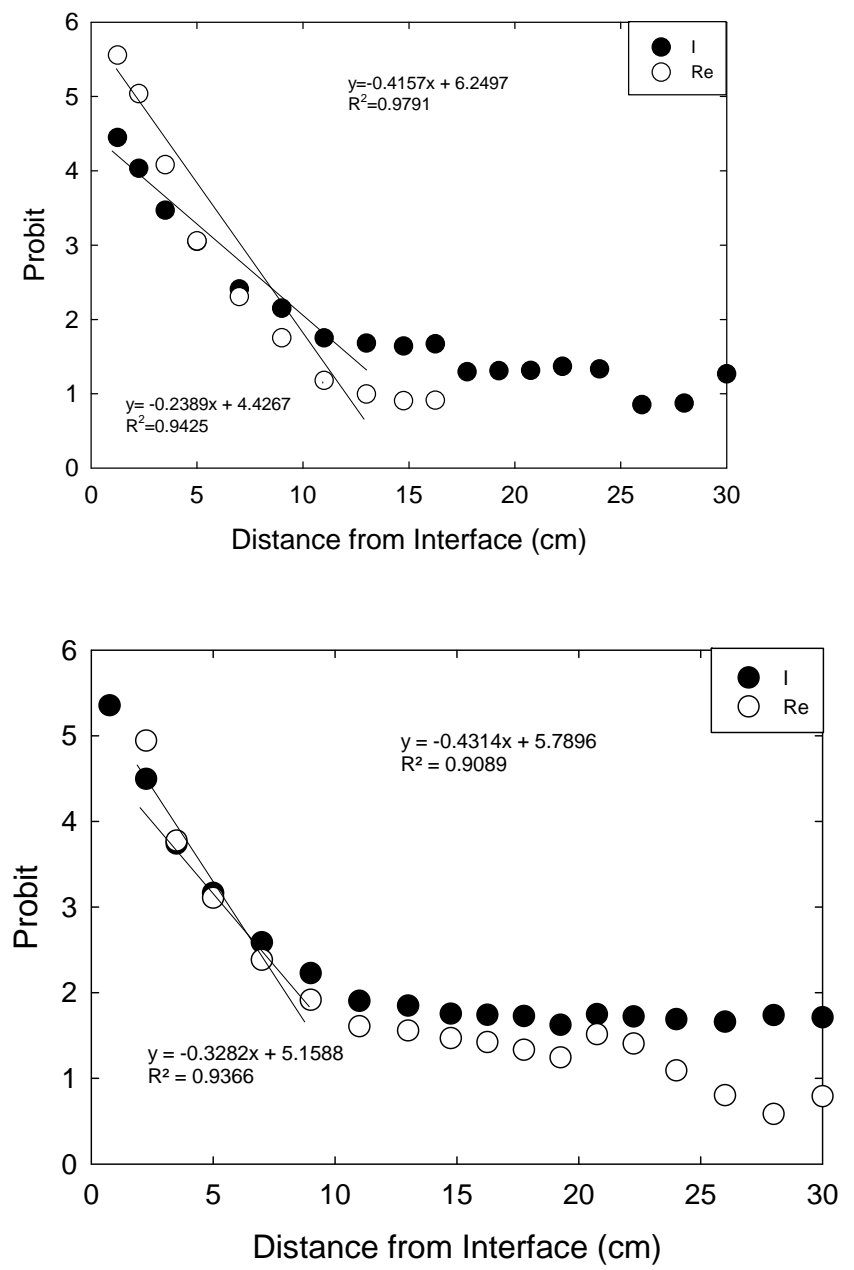
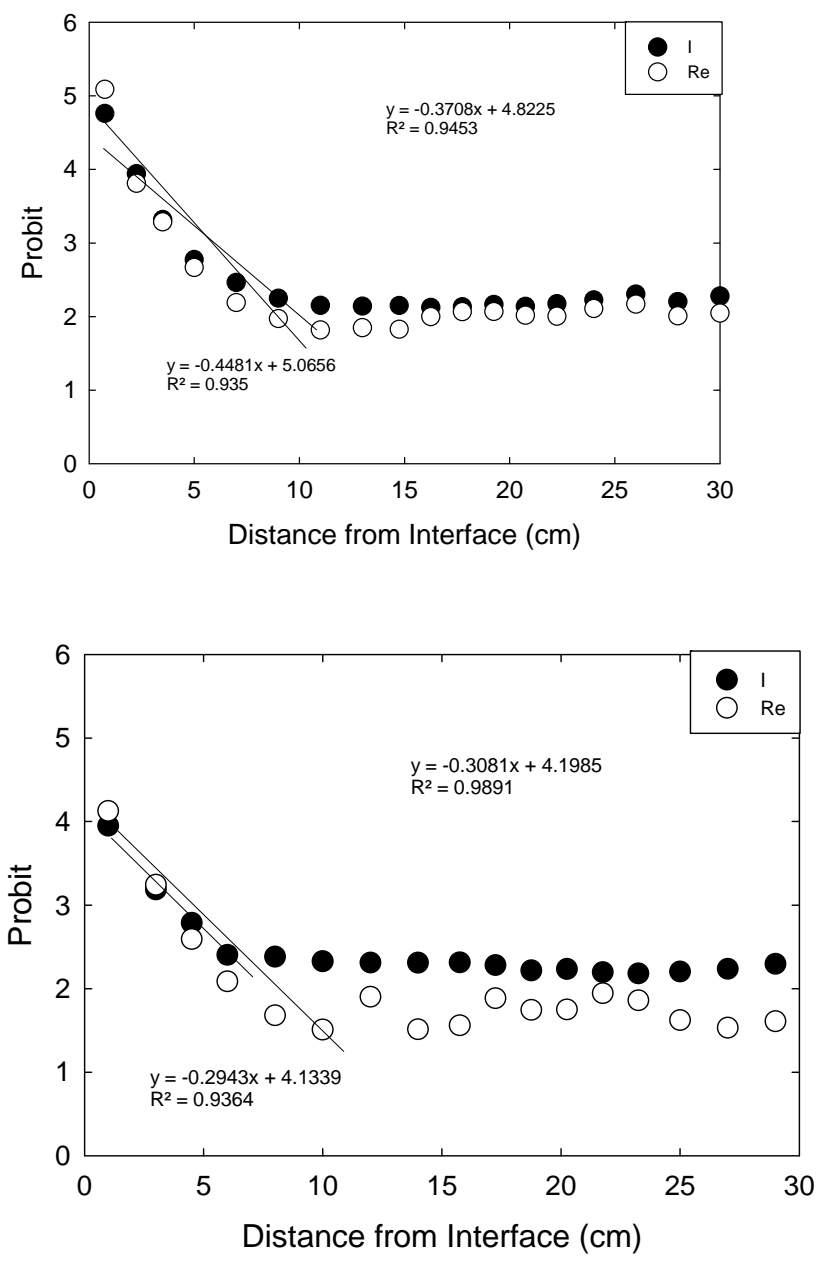

Figure 7.3. Probit plots for iodine and rhenium for soil half cells. Top left: $4 \%$ moisture content, no Fe, carbonated (CS-I-4); Top right: 4\% moisture content, no Fe, no carbonation (CS-II-4\%); Bottom left: $4 \%$ moisture content, $4 \%$ Fe, carbonated (CS-III- $4 \%$ ); Bottom right: 4\% moisture content, $4 \% \mathrm{Fe}$, no carbonation (CS-I4-4\%). 

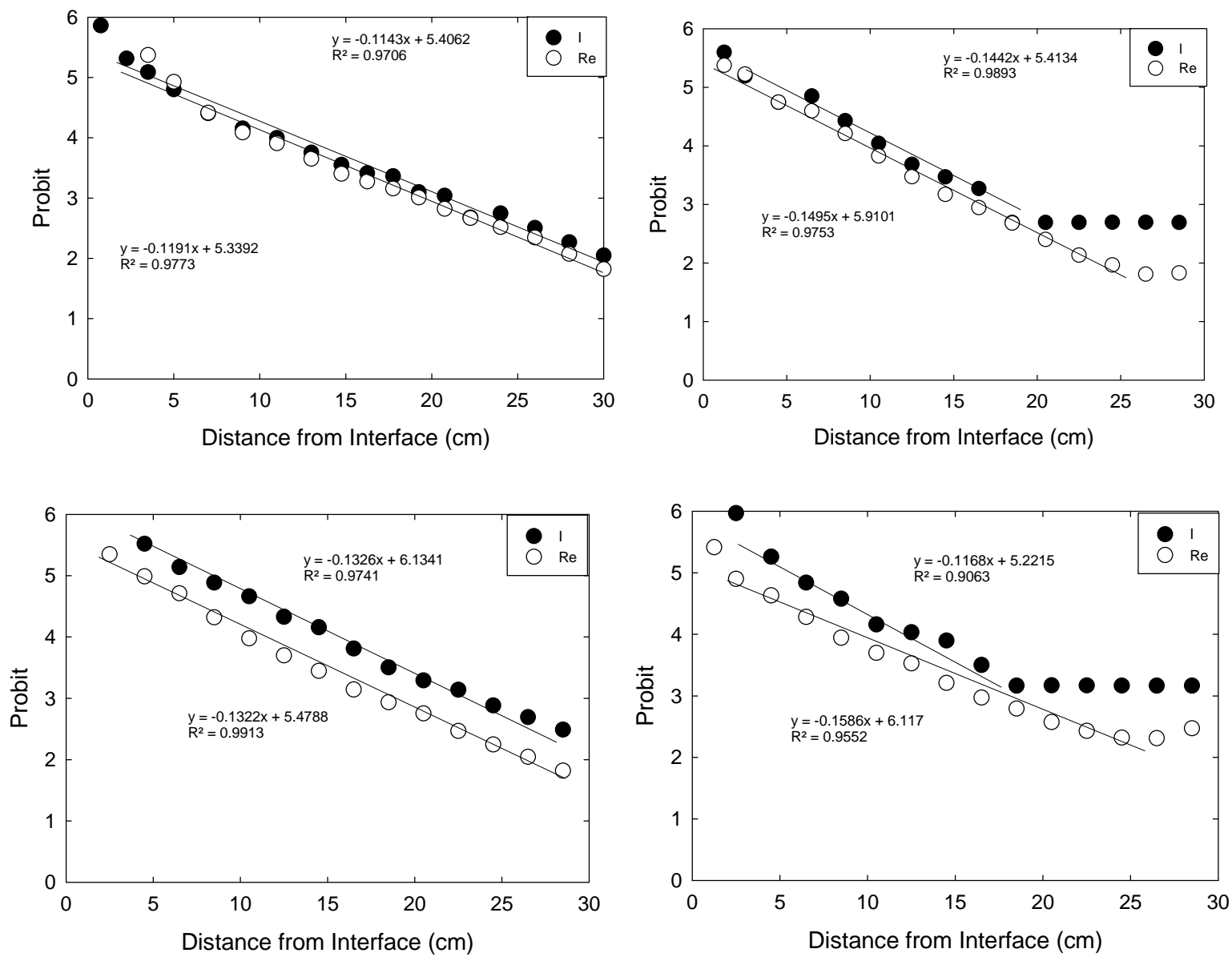

Figure 7.4. Probit plots for iodine and rhenium for soil half cells. Top left: 7\% moisture content, no Fe, carbonated (CS-I-4); Top right: 7\% moisture content, no Fe, no carbonation (CS-II-4); Bottom left: 7\% moisture content, 4\% Fe, carbonated (CS-III-4); Bottom right: 7\% moisture content, $4 \% \mathrm{Fe}$, no carbonation (CS-IV-4).

Table 7.2. Diffusivity of rhenium and iodine in soil in-soil half cells

\begin{tabular}{lccccc}
\hline & $\begin{array}{c}\text { Initial Soil } \\
\text { Moisture } \\
\text { Content } \\
\text { Core ID }\end{array}$ & $\begin{array}{c}\text { Concrete } \\
\text { Half Cell } \\
\text { Fe }(\%)\end{array}$ & $\begin{array}{c}\text { Concrete } \\
\text { Half Cell } \\
\text { Carbonation }\end{array}$ & $\begin{array}{c}\text { Re } \\
\text { Diffusivity } \\
\left(\mathrm{cm}^{2} / \mathrm{s}\right)\end{array}$ & $\begin{array}{c}\text { I Diffusivity } \\
\left(\mathrm{cm}^{2} / \mathrm{s}\right)\end{array}$ \\
\hline CS-I-4\% & 4 & 0 & Yes & $1.47 \mathrm{E}-09$ & $4.45 \mathrm{E}-08$ \\
CS-II-4\% & 4 & 0 & No & $1.26 \mathrm{E}-09$ & $1.85 \mathrm{E}-09$ \\
CS-III-4\% & 4 & $4^{(\mathrm{a})}$ & Yes & $1.36 \mathrm{E}-09$ & $2.36 \mathrm{E}-09$ \\
CS-IV-4\% & 4 & $4^{(\mathrm{a})}$ & No & $2.93 \mathrm{E}-09$ & $2.67 \mathrm{E}-09$ \\
CS-I-7\% & 7 & 0 & Yes & $5.78 \mathrm{E}-08$ & $6.28 \mathrm{E}-08$ \\
CS-II-7\% & 7 & 0 & No & $3.67 \mathrm{E}-08$ & $3.94 \mathrm{E}-08$ \\
CS-III-7\% & 7 & $4^{(\mathrm{a})}$ & Yes & $4.69 \mathrm{E}-08$ & $4.67 \mathrm{E}-08$ \\
CS-IV-7\% & 7 & $4^{(\mathrm{a})}$ & No & $3.26 \mathrm{E}-08$ & $6.01 \mathrm{E}-08$ \\
\hline
\end{tabular}

(a) Steel fiber. 



\subsection{Concrete-Soil Half-Cell Experiments to Determine the Diffusion of lodine and Rhenium into Concrete}

A set of diffusion experiments were conducted with concrete half cells prepared with and without metallic iron, and carbonation conducted using carbonate solution. These tests were set up under unsaturated conditions ( $4 \%, 7 \%$, and $15 \%$ moisture content by weight). Soil half-cell specimens were spiked with I and Re to achieve a measurable diffusion profile into the concrete part of the half cell. Experimental conditions in these tests were similar to the successful concrete-soil and soil-soil half-cell experiments conducted previously that measured contaminant migration from concrete to soil and soil to soil. However, in these experiments, the diffusion profile in concrete was determined by directly measuring the concentrations in extracts of sliced and crushed concrete half cells. At the end of the experiments, the soil and concrete half cells were sectioned to measure the concentration of I and $\mathrm{Re}$ using ICP-MS and Inductively Coupled Plasma Optical Emission spectrometry (ICP-OES), respectively, in soil and concrete thin slices. Probit plots were constructed from the concentration data and the diffusion coefficients for these contaminants were determined. We also correlated the calculated diffusion coefficients with the degree of micro-cracking in the cement specimens used in the half-cell experiments.

\subsection{Concrete-Soil Half Cells}

Diffusion tests were conducted to assess the effects of concrete carbonation and the inclusion of colloidal iron on the rate of diffusion of key, long-lived mobile contaminants (I, Re/ Tc) in spiked, unsaturated Hanford Site sediments ( 4\%, 7\%, and $15 \%$ moisture content by weight) in contact with a concrete monolith. Stable I and Re were added to the water component prior to mixing with the sediment. The experiments were conducted using a half cell of Trench 8 soil ( $\sim \mathrm{cm}$ diameter and $10 \mathrm{~cm}$ long) spiked with $\mathrm{I}$ and Re in contact with a concrete monolith $(\sim 4 \mathrm{~cm}$ diameter and $\sim 4 \mathrm{~cm}$ long). Trench 8 soil is a medium-coarse sand obtained from the sidewall of trench 8 in the W-5 burial ground located in the 200 West Area on the Hanford Site. The physical, chemical, and mineralogical properties of this soil have been previously characterized by Serne et al. (1993). Concrete monoliths were prepared in two separate batches based on the laboratory-scale specifications for the concrete. One batch contained iron particles, the other batch did not contain any added iron. Within the two batches of concrete, with iron and without iron, half the monoliths were carbonated using supercritical carbon dioxide. The resulting compositions consisted of four concrete specimens: 1) no iron, carbonated; 2) no iron, not carbonated; 3) iron, carbonated; and 4) iron, not carbonated. The characteristics of the specimens are listed in Table 8.1

The diffusion tests were conducted under unsaturated conditions at $4 \%, 7 \%$, and $15 \%$ (moisture content by weight). One concrete core of each composition was encased in a Schedule 40, $24 \mathrm{~cm}$ long, PVC pipe. The volume of each pipe was filled with Hanford Site sediment at 4\%, $7 \%$, or $15 \%$ (moisture content by weight), respectively. The ends of each pipe were machined and fit with O-ring gaskets to ensure the test cells were sealed. The diffusion tests were allowed to set horizontally and undisturbed for a period of 1 year with periodic rotation of the cell by 90 degrees. Characteristics of the concrete-soil diffusion half cells are listed in Table 7.1 
Table 8.1. Characteristics of concrete half cells

\begin{tabular}{cccccccc}
\hline $\begin{array}{c}\text { Specimen } \\
\text { No. }\end{array}$ & $\begin{array}{c}\text { Length } \\
(\mathrm{cm})\end{array}$ & $\begin{array}{c}\text { Diameter } \\
(\mathrm{cm})\end{array}$ & $\begin{array}{c}\text { Surface Area } \\
\left(\mathrm{cm}^{2}\right)\end{array}$ & $\begin{array}{c}\text { Volume } \\
\left(\mathrm{cm}^{3}\right)\end{array}$ & $\begin{array}{c}\text { Density } \\
\left(\mathrm{g} / \mathrm{cm}^{3}\right)\end{array}$ & $\begin{array}{c}\text { Colloidal } \\
\text { Iron }\end{array}$ & Carbonated \\
\hline 1 & 4.21 & 4.32 & 86.26 & 61.50 & 2.21 & Yes & Yes \\
2 & 4.33 & 4.32 & 87.99 & 63.37 & 2.18 & Yes & No \\
3 & 4.26 & 4.32 & 87.23 & 62.55 & 2.08 & No & Yes \\
4 & 4.39 & 4.33 & 89.09 & 64.55 & 2.04 & No & No \\
5 & 4.34 & 4.32 & 88.16 & 63.55 & 2.23 & Yes & Yes \\
6 & 4.26 & 4.33 & 87.22 & 62.54 & 2.21 & Yes & No \\
7 & 4.15 & 4.32 & 85.69 & 60.89 & 2.10 & No & Yes \\
8 & 4.38 & 4.32 & 88.72 & 64.16 & 2.06 & No & No \\
9 & 4.27 & 4.32 & 87.15 & 62.46 & 2.23 & Yes & Yes \\
10 & 4.27 & 4.32 & 87.39 & 62.73 & 2.19 & Yes & No \\
11 & 4.15 & 4.33 & 85.76 & 60.95 & 2.08 & No & Yes \\
12 & 4.43 & 4.32 & 89.58 & 65.09 & 2.06 & No & No \\
\hline
\end{tabular}

Table 8.2. Characteristics of the soil half cells

\begin{tabular}{|c|c|c|c|c|c|c|c|}
\hline Cell No. & Concrete Treatment & $\begin{array}{l}\text { I Conc. } \\
\text { (g/g soil) }\end{array}$ & $\begin{array}{l}\text { Re Conc. } \\
\text { (g/g soil) }\end{array}$ & $\begin{array}{l}\text { Volume } \\
\text { of Soil } \\
\text { Half- } \\
\text { Cell } \\
\left(\mathrm{cm}^{3}\right)\end{array}$ & $\begin{array}{l}\text { Density } \\
\text { Soil } \\
\left(\mathrm{g} / \mathrm{cm}^{3}\right)\end{array}$ & $\begin{array}{c}\text { Initial } \\
\text { Soil } \\
\text { Moisture } \\
\text { Content } \\
(\%)\end{array}$ & $\begin{array}{c}\text { Test } \\
\text { Duration } \\
\text { (days) }\end{array}$ \\
\hline CS-I-4\% & Iron, carbonated & $1.35 \times 10^{-2}$ & $1.34 \times 10^{-2}$ & 742.82 & 1.58 & 4.0 & 348 \\
\hline CS-II-4\% & Iron, not carbonated & $1.35 \times 10^{-2}$ & $1.34 \times 10^{-2}$ & 737.14 & 1.56 & 4.0 & 348 \\
\hline CS-III-4\% & No iron, carbonated & $1.35 \times 10^{-2}$ & $1.34 \times 10^{-2}$ & 734.82 & 1.58 & 4.0 & 348 \\
\hline CS-IV-4\% & No iron, not carbonated & $1.35 \times 10^{-2}$ & $1.34 \times 10^{-2}$ & 730.59 & 1.56 & 4.0 & 348 \\
\hline CS-I-7\% & Iron, carbonated & $1.25 \times 10^{-2}$ & $1.25 \times 10^{-2}$ & 741.69 & 1.61 & 7.1 & 354 \\
\hline CS-II-7\% & Iron, not carbonated & $1.25 \times 10^{-2}$ & $1.25 \times 10^{-2}$ & 742.04 & 1.62 & 7.1 & 354 \\
\hline CS-III-7\% & No iron, carbonated & $1.25 \times 10^{-2}$ & $1.25 \times 10^{-2}$ & 733.44 & 1.53 & 7.1 & 354 \\
\hline CS-IV-7\% & No iron, not carbonated & $1.25 \times 10^{-2}$ & $1.25 \times 10^{-2}$ & 731.27 & 1.56 & 7.1 & 354 \\
\hline CS-I- $15 \%$ & Iron, carbonated & $1.50 \times 10^{-2}$ & $1.50 \times 10^{-2}$ & 777.95 & 1.72 & 15.0 & 355 \\
\hline CS-II-15\% & Iron, not carbonated & $1.50 \times 10^{-2}$ & $1.50 \times 10^{-2}$ & 770.25 & 1.70 & 15.0 & 355 \\
\hline CS-III- $15 \%$ & No iron, carbonated & $1.50 \times 10^{-2}$ & $1.50 \times 10^{-2}$ & 768.89 & 1.72 & 15.0 & 355 \\
\hline CS-IV- $15 \%$ & No iron, not carbonated & $1.50 \times 10^{-2}$ & $1.50 \times 10^{-2}$ & 752.65 & 1.70 & 15.0 & 355 \\
\hline
\end{tabular}


At the conclusion of the test period, the sampling and analysis of the half cells were conducted as described previously in Section 6.0.

\subsection{Results and Discussion}

Figure 8.1 presents graphs depicting the concentration profiles for I and Re within the sediment half cell from concrete-soil half-cell diffusion experiments.

The inclusion of iron or effect of carbonation of the concrete half cell on the concentration profile for I and Re within the soil half cell was minimal. There were no apparent differences observed in the concentrations of I and Re between various monolith treatments. However, a consistent trend in $\operatorname{Re}$ concentration was evident based on the moisture content within the soil half cell. The relative fraction of Re within the soil half cell is significantly less at $7 \%$ and $15 \%$ as compared to $4 \%$. However, the fraction of rhenium in the soil-half cell at $7 \%$ is comparable to that at $15 \%$. Comparable behavior was previously observed in concrete-soil half-cell experiments wherein diffusion of I and Re from concrete to soil was quantified as a function of moisture content (Mattigod et al. 2001; Wellman et al. 2006). A similar trend for I was not evident in results of half-cell diffusion tests presented here. Rather, irrespective of moisture content, the fraction of I consistently ranged from 0.6 to 0.8 . At $7 \%$ and $15 \%$ moisture content, the fraction of I remaining within the sediment is consistent with that quantified for Re. However, the fraction of I in sediment at 4\% moisture content is significantly less than that quantified for Re. Upon extraction of the half cells, it was noted that the inside walls of the PVC pipe were reddish-brown. It is hypothesized that vapor-phase diffusion of I onto the walls of the PVC pipe may have occurred at $4 \%$ moisture content. There was very minimal discoloration of the PVC walls noted at $7 \%$ and $15 \%$ moisture content. It appears that under higher moisture contents, the I may be retained in the aqueous phase; whereas, at very low moisture content (4\%), it tended to partially transform into vapor phase. To determine whether vaporphase diffusion of I had occurred, 1:1 isopropyl alcohol extractions were conducted on slices of the PVC pipe. About 200 to $850 \mathrm{ppb}$ I was extracted from various segments of the PVC pipes, whereas no measurable concentrations of Re were detected in the extracts.

Figure 8.2 displays plots showing the concentration profile for I and Re within the concrete half of the concrete-soil half-cell diffusion experiments at $4 \%$ moisture content. The behavior of I and Re were markedly different within a given half-cell test. The diffusion of I into concrete was 40 to $60 \mathrm{mg} / \mathrm{g}$ within the first $5 \mathrm{~mm}$ of the concrete half cell in contact with sediment. However, the diffusion of Re was limited to $<5 \mathrm{mg} / \mathrm{g}$ within the same depth of concrete. As noted above, it is hypothesized that vapor-phase diffusion of I may be occurring under conditions of $4 \%$ moisture content, which could afford greater diffusion of I into the concrete core. Additionally, the peak concentration of I at $4 \%$ moisture content in the concrete core has moved away from the interface. Qualitatively, it appears the concentration profiles may accord with variable diffusion rates with the greatest rate occurring in the carbonate iron-bearing sample, followed by the iron-free samples, and the slowest diffusion occurring in the non-carbonated, iron-bearing sample. Also, the slight elevation in the concentration of Re at the interface of concrete monoliths not containing iron suggests iron may exert a limited influence on the diffusion of Re. 
Fe, Carbonated
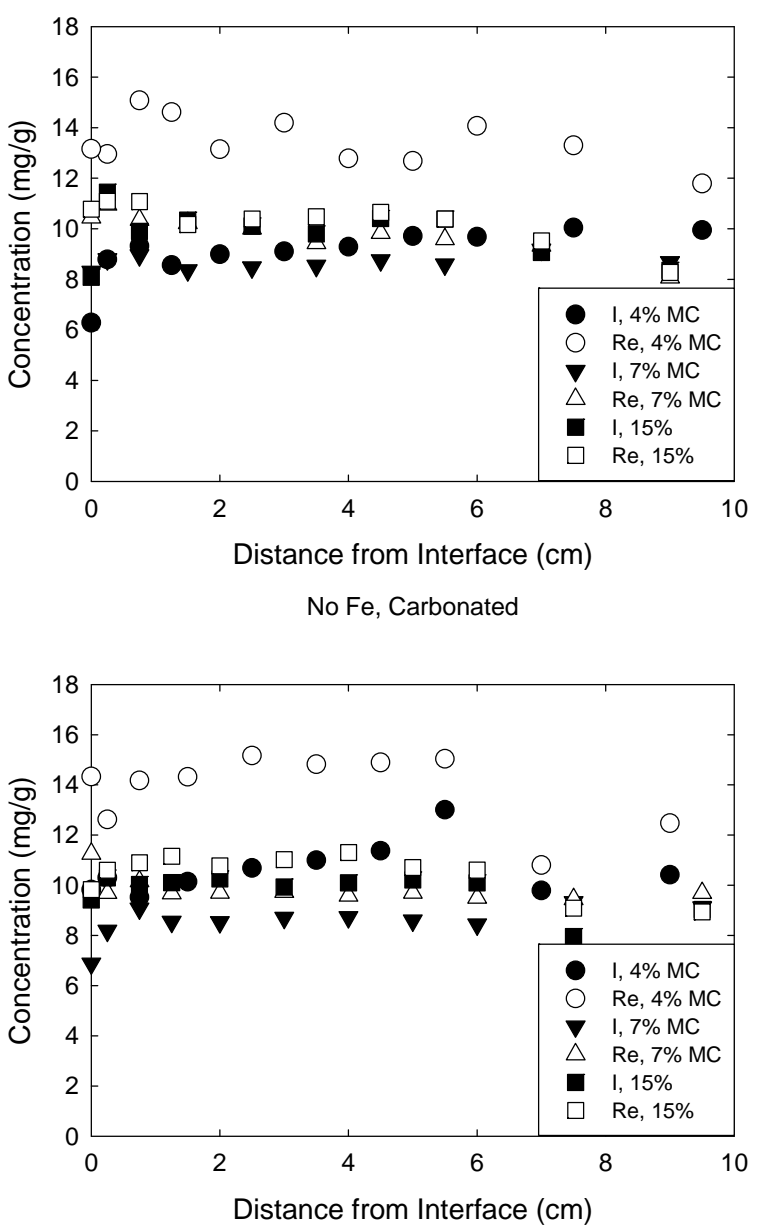

Fe, Not Carbonated
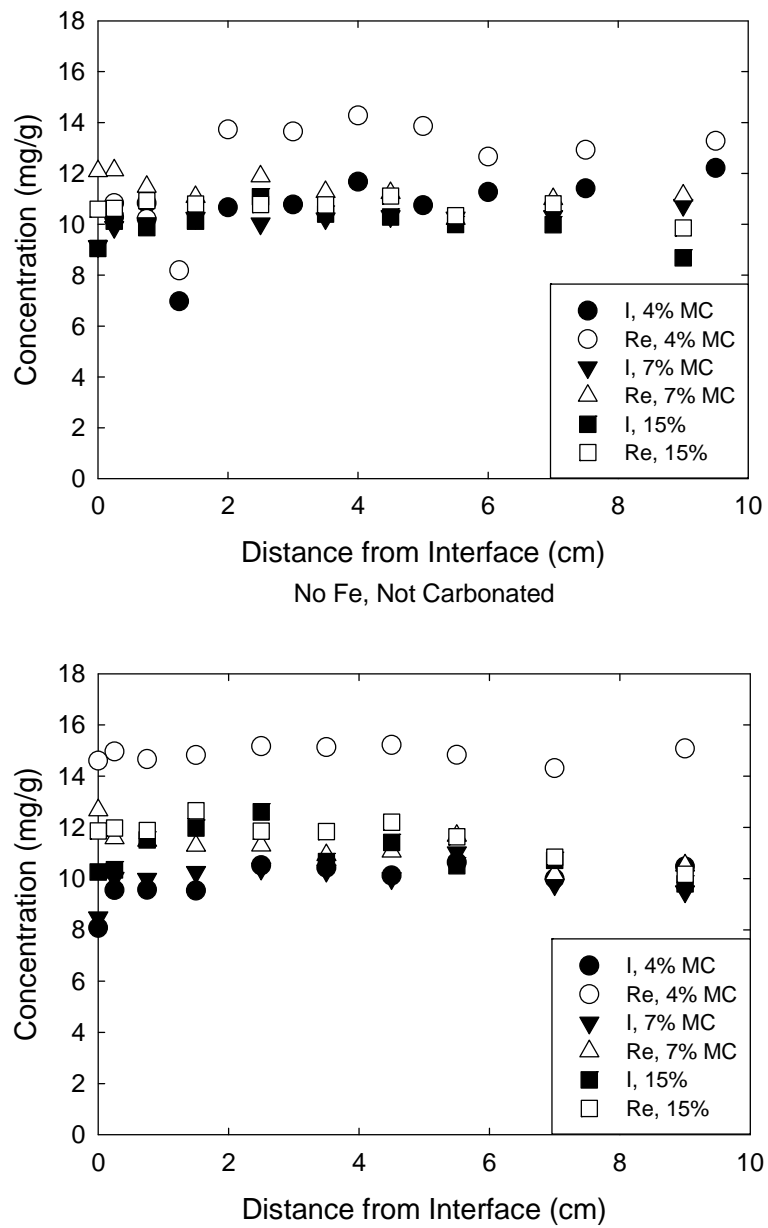

Figure 8.1. I and Re concentration profiles for soil half cells at $4 \%, 7 \%$, and $15 \%$ moisture content by weight in four types of concrete monoliths: Top left: iron, carbonated; Top right: iron, not carbonated; Bottom left: no iron, carbonated; Bottom right: no iron, not carbonated.

Figure 8.3, illustrates the concentration profiles for I and Re within the concrete half of the concretesoil half-cell diffusion experiments at $7 \%$ and $15 \%$ moisture content. The behavior of I and Re was generally comparable within a given half-cell test. The greatest concentration of I and Re were measured within the first $10 \mathrm{~mm}$ of the concrete monolith $(\sim 10-20 \mathrm{mg} / \mathrm{g})$ and there were gradual decreases in concentrations of both elements over the remaining 20 to $30 \mathrm{~mm}$ of concrete monolith. The noted exception to this were the concrete monoliths that contained no iron and were not carbonated. This set of concrete monoliths displayed a more rapid decrease in concentration within the first 10 to $20 \mathrm{~mm}$. As demonstrated previously, the inclusion of iron and the effect of carbonation result in the formation of micro-cracks within the concrete monoliths (Wellman et al. 2006) that apparently facilitate diffusion. The absence of iron in the uncarbonated core likely limited the potential formation of any micro-cracks, thus limiting diffusion of I and Re into the concrete monolith from the contaminated sediment. Increased micro-cracking in the presence of $\mathrm{Fe}$ and for concrete monoliths that had undergone carbonation agrees with results of previous investigations (Wellman et al. 2006). 

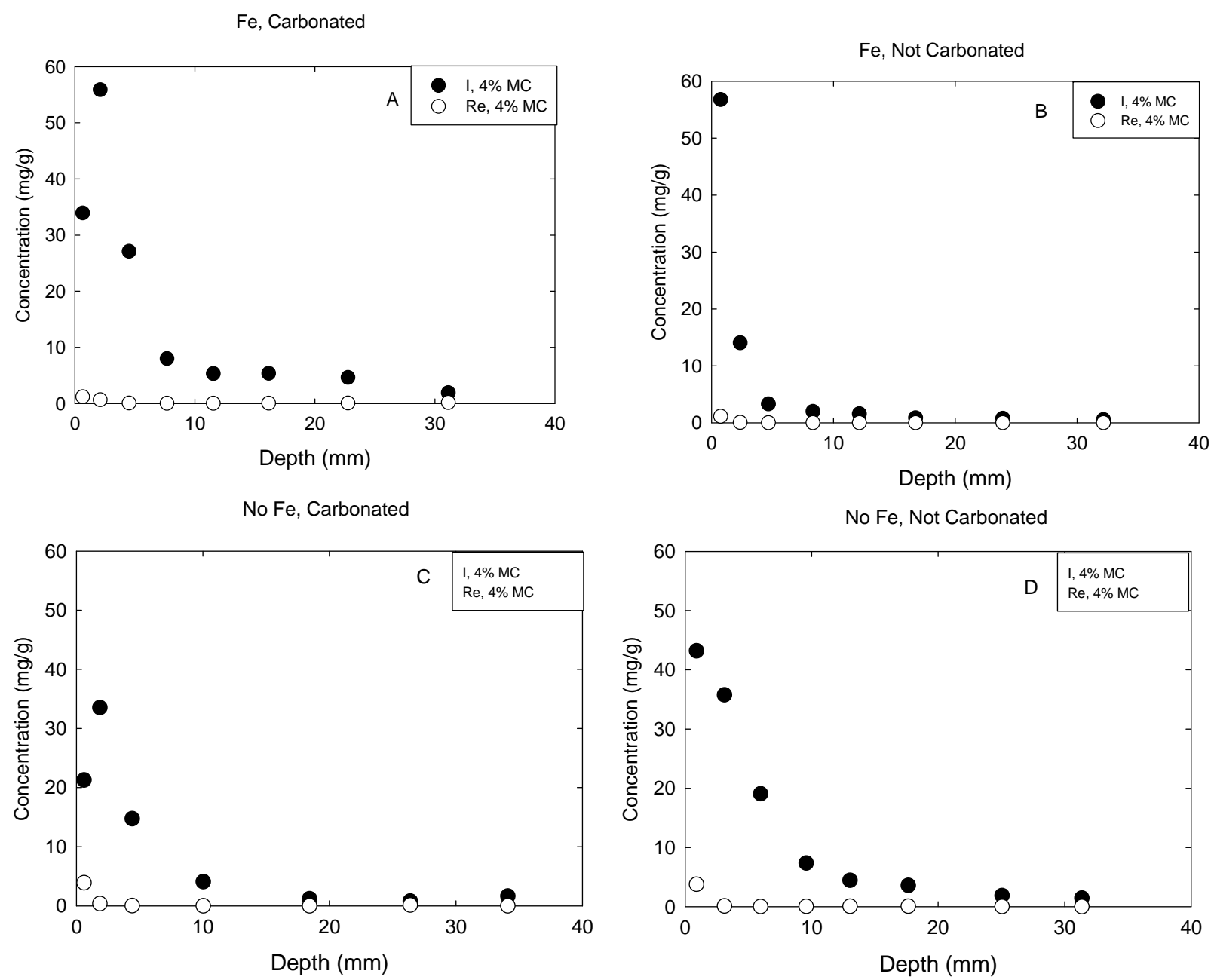

Figure 8.2. I and Re concentration profiles for concrete half cells at $4 \%$, moisture content by weight in four types of concrete monoliths: Top left: iron, carbonated; Top right: iron, not carbonated; Bottom left: no iron, carbonated; Bottom right: no iron, not carbonated.

The concentrations of I and Re quantified within the monoliths were much lower at the interface than that measured at $4 \%$ moisture content $(40-60 \mathrm{mg} / \mathrm{g}$ at $4 \%$ moisture content versus $10-20 \mathrm{mg} / \mathrm{g}$ at $7 \%$ and $15 \%$ moisture content). Furthermore, the depth of diffusion of I and Re into the concrete monoliths was greater at higher moisture contents. At 4\% moisture content, the concentration of I was greatest within the first $5 \mathrm{~mm}$ and displayed a rapid asymptotic decrease in concentration to $\sim 1 \mathrm{mg} / \mathrm{g}$ within the first $10 \mathrm{~mm}$. The behavior of I and Re at 7\% and 15\% moisture content was generally greatest within the first $10 \mathrm{~mm}$, with a more gradual decrease over the remaining 20 to $30 \mathrm{~mm}$. This, in accordance with previous results, suggests a direct relationship between diffusion within concrete monoliths and the degree of moisture content in the contacting soil half cells (Wellman et al. 2006; Mattigod et al. 2001). However, the comparison of diffusion of I and Re at $7 \%$ and $15 \%$ shows a number of deviations. In the concrete monolith without iron and not carbonated, the diffusion of I appears to be more rapid than that observed at $15 \%$. Conversely, in the concrete monolith containing iron, but not carbonated, the diffusion of iodine is noticeably greater than that at 7\%. This behavior is also evident for Re. Diffusion of I and Re in carbonated monoliths does not exhibit such deviations. 
Fe, Carbonated

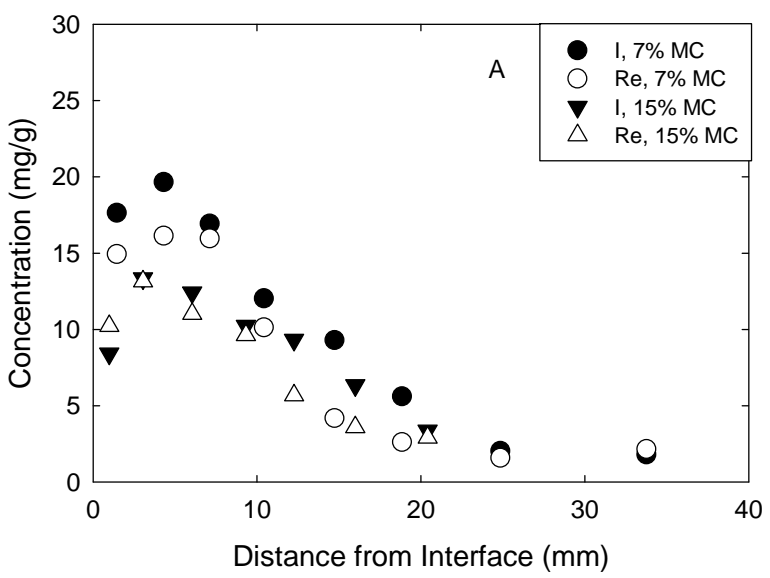

No Fe, Carbonated

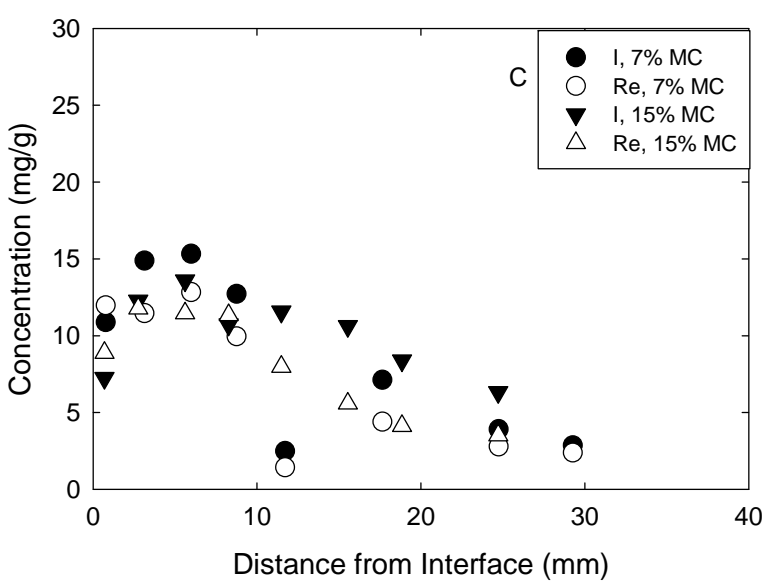

Fe, Not Carbonated
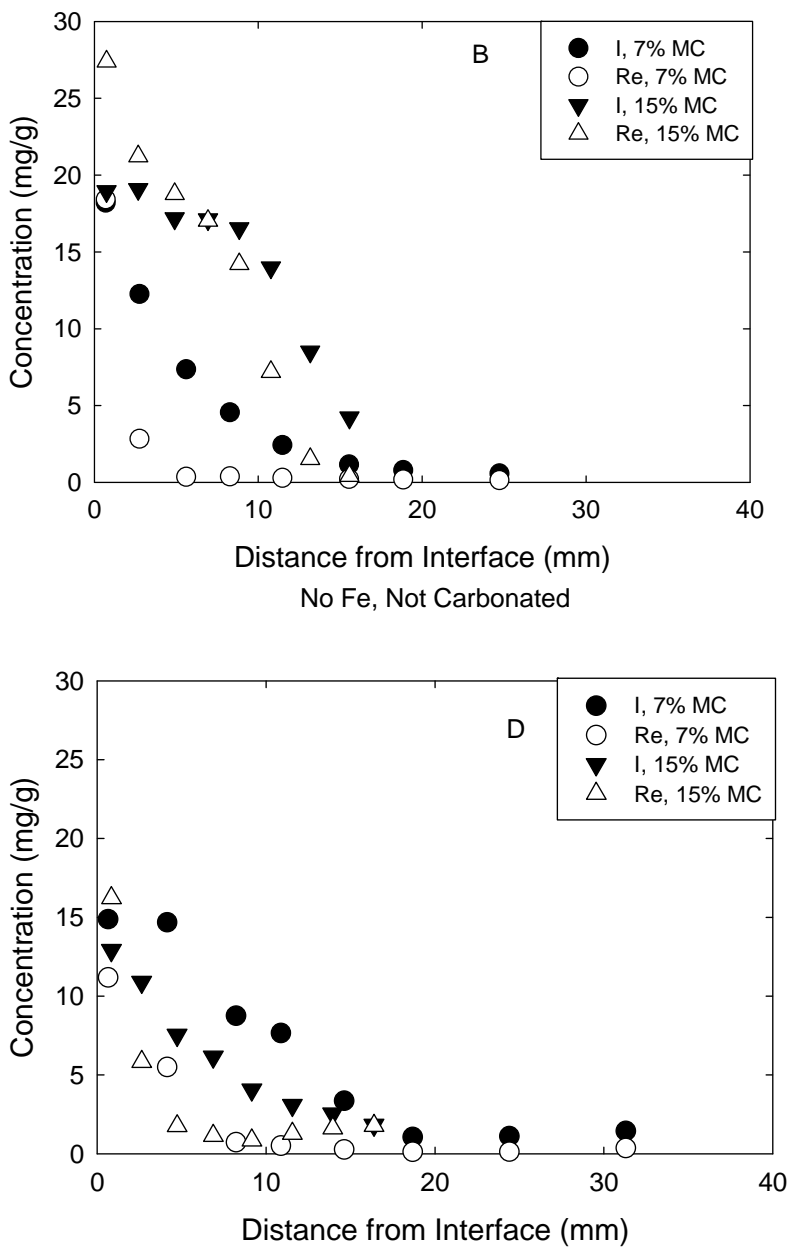

Figure 8.3. I and Re concentration profiles for concrete half cells at $7 \%$ and $15 \%$ moisture content by weight in four types of concrete monoliths: Top left: iron, carbonated; Top right: iron, not carbonated; Bottom left: no iron, carbonated; Bottom right: no iron, not carbonated.

Not all of the concentration distribution data from concrete cores were amenable for probit analysis. In most of the cases, the probit plots were non-linear or the linear sections had fewer than four data points. Concentration profiles for only five concrete cores yielded data for further analysis. Therefore, probit plots were constructed for cases where sufficient data points were available to define statistically significant linear functional relationships (Figure 8.4). The resulting diffusivities of Re and I are listed in Table 8.3. 

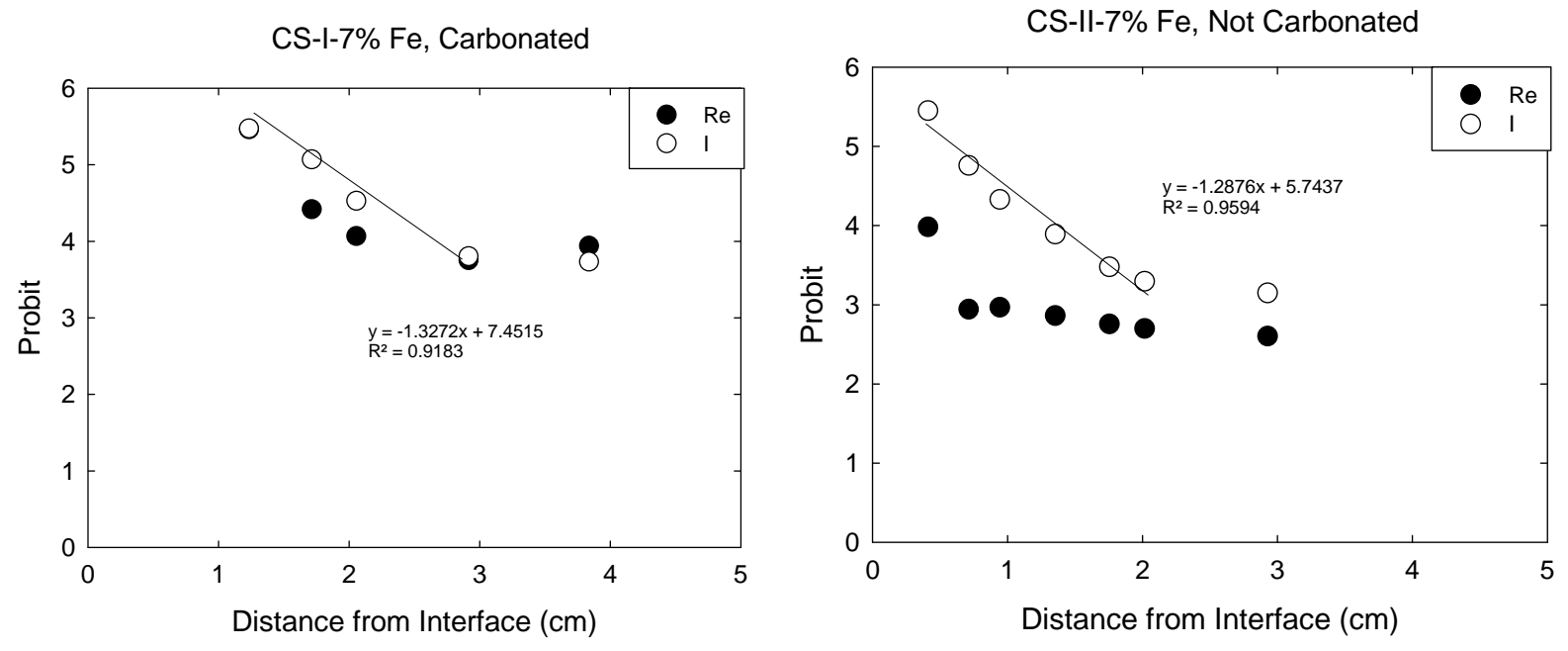

CS-III-7\% No Fe, Carbonated
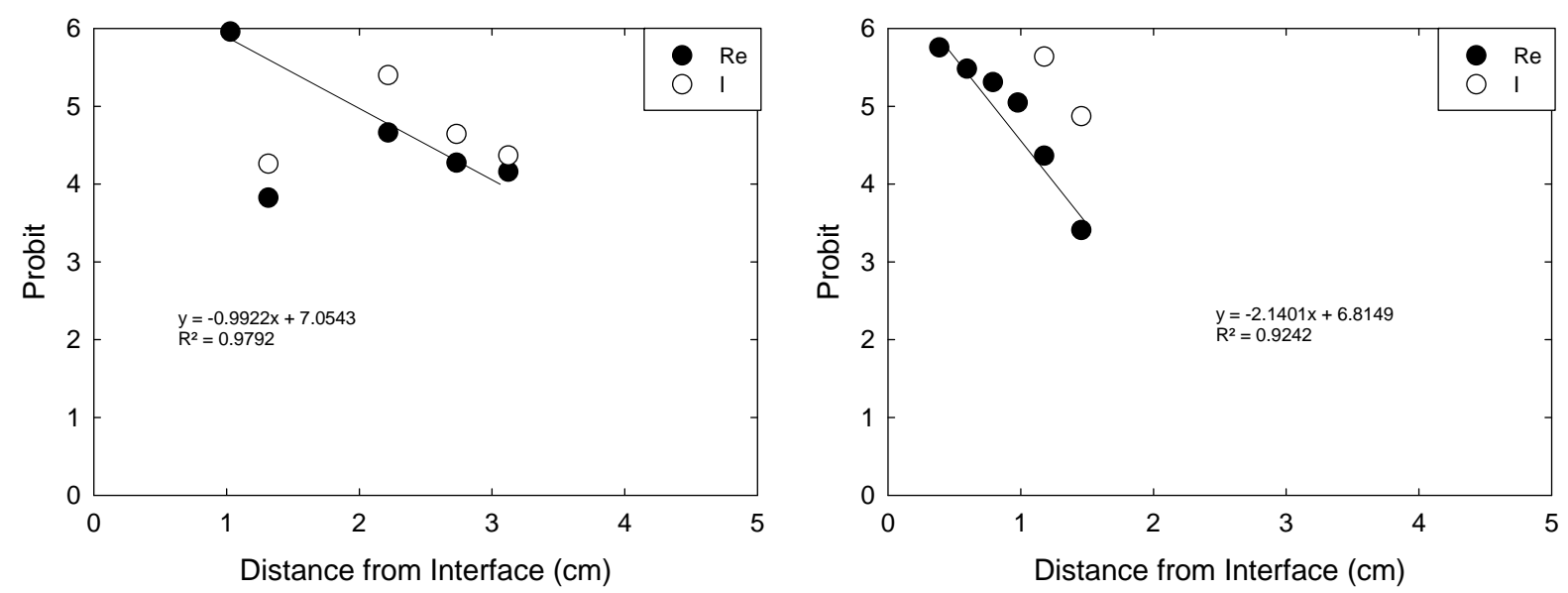

CS-IV-15\% No Fe, Not Carbonated

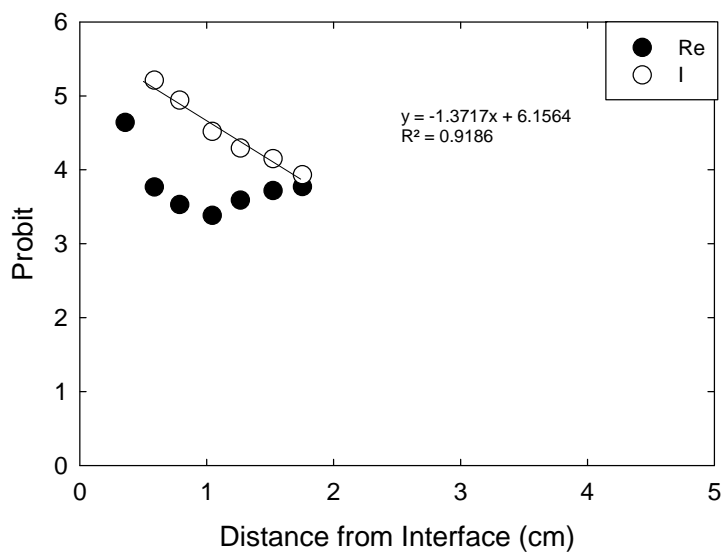

Figure 8.4. Probit plots for iodine and rhenium for concrete half cells. Top left: 7\% moisture content, Fe, carbonated; Top right: 7\% moisture content, Fe, no carbonation; Middle left: 7\% moisture content, no Fe, carbonated; Middle right: 15\% moisture content, Fe, not carbonated; Bottom: $15 \%$ moisture content, no Fe, not carbonated. 
Table 8.3. Diffusivity of rhenium and iodine in concrete half cells

\begin{tabular}{lccccc}
\hline & $\begin{array}{c}\text { Initial Soil } \\
\text { Moisture } \\
\text { Content (\%) }\end{array}$ & $\begin{array}{c}\text { Concrete } \\
\text { Half cell } \\
\mathrm{Fe}^{(\mathrm{a})}(\%)\end{array}$ & $\begin{array}{c}\text { Concrete Half } \\
\text { Cell Carbonation }\end{array}$ & $\begin{array}{c}\text { Re Diffusivity } \\
\left(\mathrm{cm}^{2} / \mathrm{s}\right)\end{array}$ & $\begin{array}{c}\text { I Diffusivity } \\
\left(\mathrm{cm}^{2} / \mathrm{s}\right)\end{array}$ \\
\hline CS-I-7\% & 7 & 4 & $\mathrm{Y}$ & $(\mathrm{b})$ & $2.18 \times 10^{-10}$ \\
CS-II-7\% & 7 & 4 & $\mathrm{~N}$ & (b) & $2.32 \times 10^{-10}$ \\
CS-III-7\% & 7 & 0 & $\mathrm{Y}$ & $9.34 \times 10^{-10}$ & (b) \\
CS-II-15\% & 15 & 4 & $\mathrm{~N}$ & $2.00 \times 10^{-10}$ & (b) \\
CS-IV-15\% & 15 & 0 & $\mathrm{~N}$ & (b) & $2.04 \times 10^{-10}$ \\
\hline
\end{tabular}

(a) Steel fiber

(b) Probit analysis could not be performed due to poorly defined diffusion profile.

In Summary:

The probit plots and the calculations yielded two values of diffusivity for Re that were $9.3 \times 10^{-10} \mathrm{~cm}^{2} / \mathrm{s}$ and $2.0 \times 10^{-10} \mathrm{~cm}^{2} / \mathrm{s}$ respectively. Due to the lack of a sufficient number of diffusivity values, the effect of various parameters, such as moisture content and the presence of iron and carbonation, cannot be assessed.

The results indicated that the diffusivity of I was relatively constant $\left(\sim 2.3 \times 10^{-10} \mathrm{~cm}^{2} / \mathrm{s}\right)$ and was not affected by either the concrete core treatment (Fe and carbonation) or by the moisture content of the spiked soil half-cell source. 


\subsection{Effects of Carbonation and Metallic Iron on the Diffusion of Technetium and lodine in Soils and Concrete}

Two sets of diffusion experiments were initiated using carbonated (by immersion in sodium carbonate solution) concrete-soil half cells. The reason for solution-immersion carbonation of specimens in these experiments was to avoid the development of micro-cracking of the specimens engendered by supercritical carbonation. Soil half-cell specimens were spiked with I and Tc to achieve a measurable diffusion profile in the concrete part of the half-cell. The characteristics of the concrete half cells are listed in Table 9.1. These experiments were set up as described previously (Section 5.0). The concentration data, probit plots, and diffusion coefficients for these contaminants are presented below.

Table 9.1. Characteristics of concrete specimens used in concrete-soil half cells

\begin{tabular}{|c|c|c|c|}
\hline Core ID & $\begin{array}{c}\text { Initial Moisture } \\
\text { Content }^{(\mathrm{a})}(\mathrm{Wt} \%)\end{array}$ & Carbonation & $\mathrm{Fe}(\mathrm{wt} \%)$ \\
\hline Tc-C-08-3-0-325 & 4 & $\mathrm{~N}$ & 0 \\
\hline Tc-C-08-3-0-329 & 7 & $\mathrm{~N}$ & 0 \\
\hline Tc-C-08-3-0-330 & 15 & $\mathrm{~N}$ & 0 \\
\hline Tc-C-08-3-0-332 & 4 & $\mathrm{Y}$ & 0 \\
\hline Tc-C-08-3-0-333 & 7 & $\mathrm{Y}$ & 0 \\
\hline Tc-C-08-3-0-334 & 15 & $\mathrm{Y}$ & 0 \\
\hline Tc-C-08-3-4-350 & 4 & $\mathrm{~N}$ & 4 \\
\hline Tc-C-08-3-4-351 & 7 & $\mathrm{~N}$ & 4 \\
\hline Tc-C-08-3-4-353 & 15 & $\mathrm{~N}$ & 4 \\
\hline Tc-C-08-3-4-357 & 4 & $\mathrm{Y}$ & 4 \\
\hline Tc-C-08-3-4-359 & 7 & Y & 4 \\
\hline Tc-C-08-3-4-360 & 15 & $\mathrm{Y}$ & 4 \\
\hline Tc-C-08-3-8-401 & 4 & $\mathrm{~N}$ & 8 \\
\hline Tc-C-08-3-8-402 & 7 & $\mathrm{~N}$ & 8 \\
\hline Tc-C-08-3-8-403 & 15 & $\mathrm{~N}$ & 8 \\
\hline Tc-C-08-3-8-407 & 4 & $\mathrm{Y}$ & 8 \\
\hline Tc-C-08-3-8-409 & 7 & Y & 8 \\
\hline Tc-C-08-3-8-410 & 15 & $\mathrm{Y}$ & 8 \\
\hline Tc-C-08-3-12-425 & 4 & $\mathrm{~N}$ & 12 \\
\hline Tc-C-08-3-12-426 & 7 & $\mathrm{~N}$ & 12 \\
\hline Tc-C-08-3-12-427 & 15 & $\mathrm{~N}$ & 12 \\
\hline Tc-C-08-3-12-432 & 4 & Y & 12 \\
\hline Tc-C-08-3-12-433 & 7 & $\mathrm{Y}$ & 12 \\
\hline Tc-C-08-3-12-435 & 15 & $\mathrm{Y}$ & 12 \\
\hline
\end{tabular}

\subsection{Results and Discussion}

The diffusion profiles of soil half cells spiked with I and Tc are shown in Figures 9.1 through 9.3, and the concrete half cells are shown in Figures 9.4 through 9.6. Except very near the interfaces, no distinctive concentration gradients were observed in any of the soil half cells. Therefore, on average, the relatively constant concentrations throughout the soil half cells reflected the spike concentrations of I and Tc, respectively. 

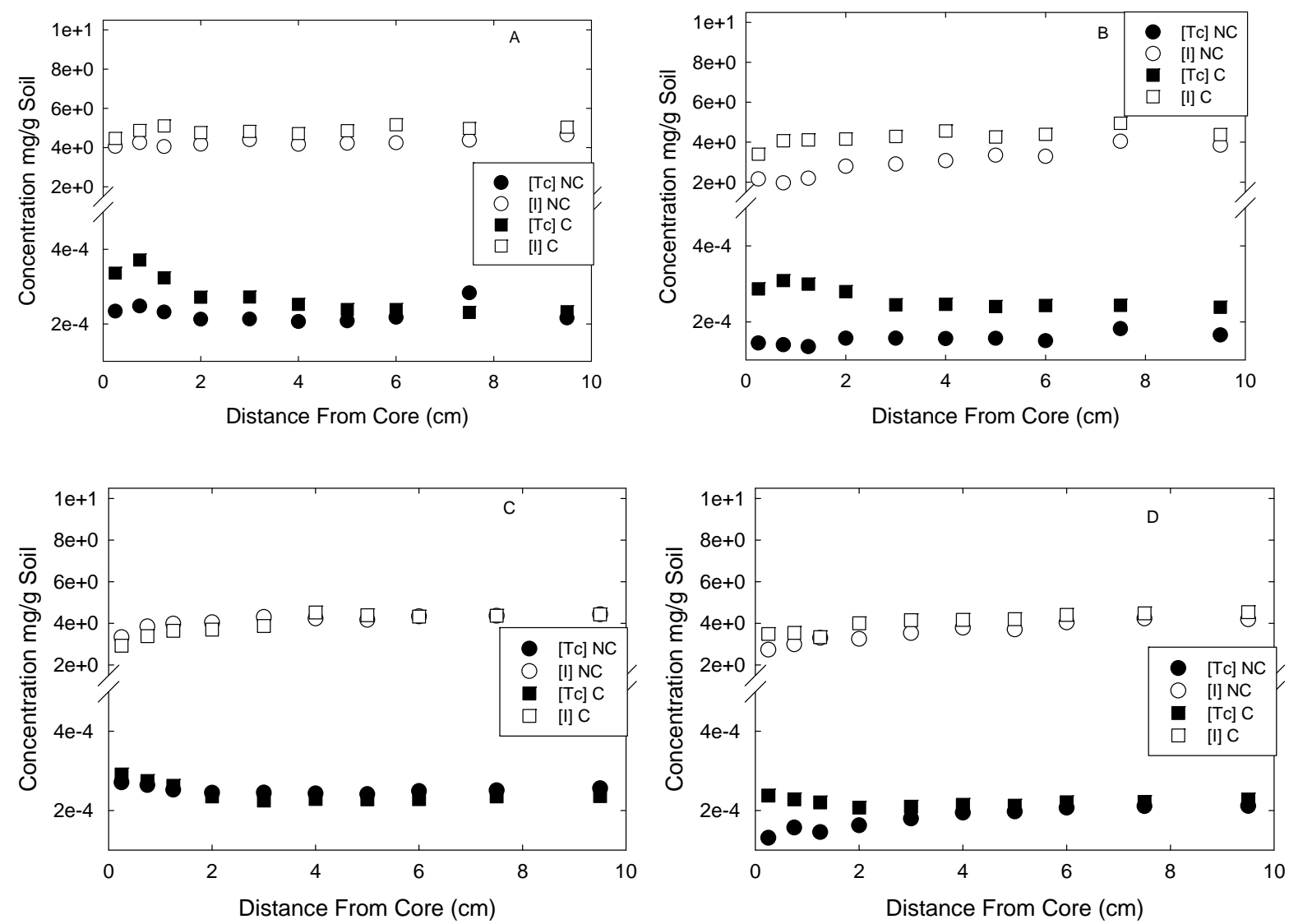

Figure 9.1. Tc and I soil concentration profiles. Top left: $4 \%$ soil moisture, $0 \% \mathrm{Fe}$; Top right: $4 \%$ soil moisture, $4 \% \mathrm{Fe}$; Bottom left: $4 \%$ soil moisture, $8 \% \mathrm{Fe}$; Bottom right: $4 \%$ soil moisture, $12 \% \mathrm{Fe}$. 

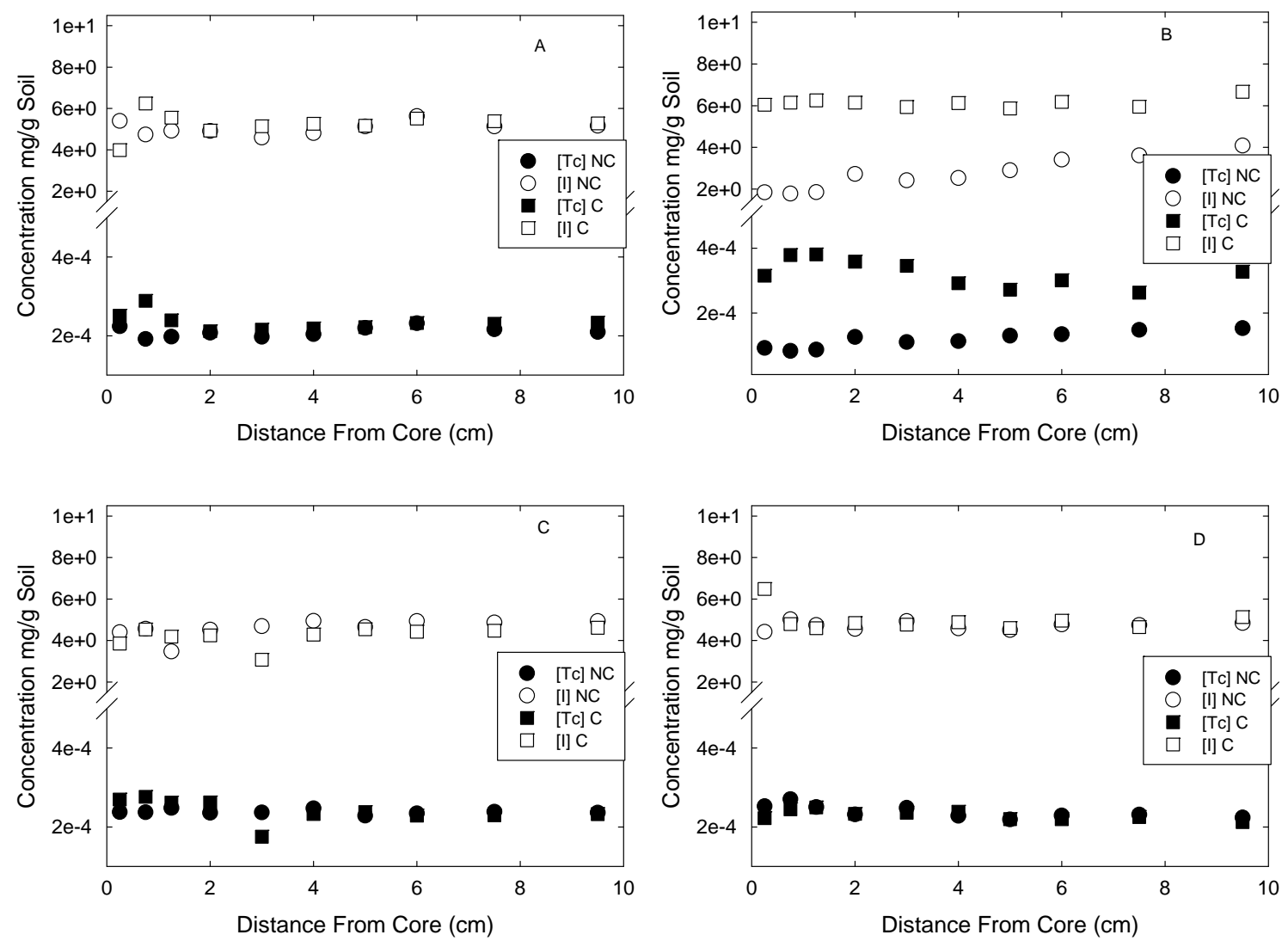

Figure 9.2. Tc and I soil concentration profiles. Top left: 7\% soil moisture, $0 \%$ Fe; Top right: $7 \%$ soil moisture, $4 \%$ Fe; Bottom left: $7 \%$ soil moisture, $8 \%$ Fe; Bottom right: $7 \%$ soil moisture, $12 \% \mathrm{Fe}$. 

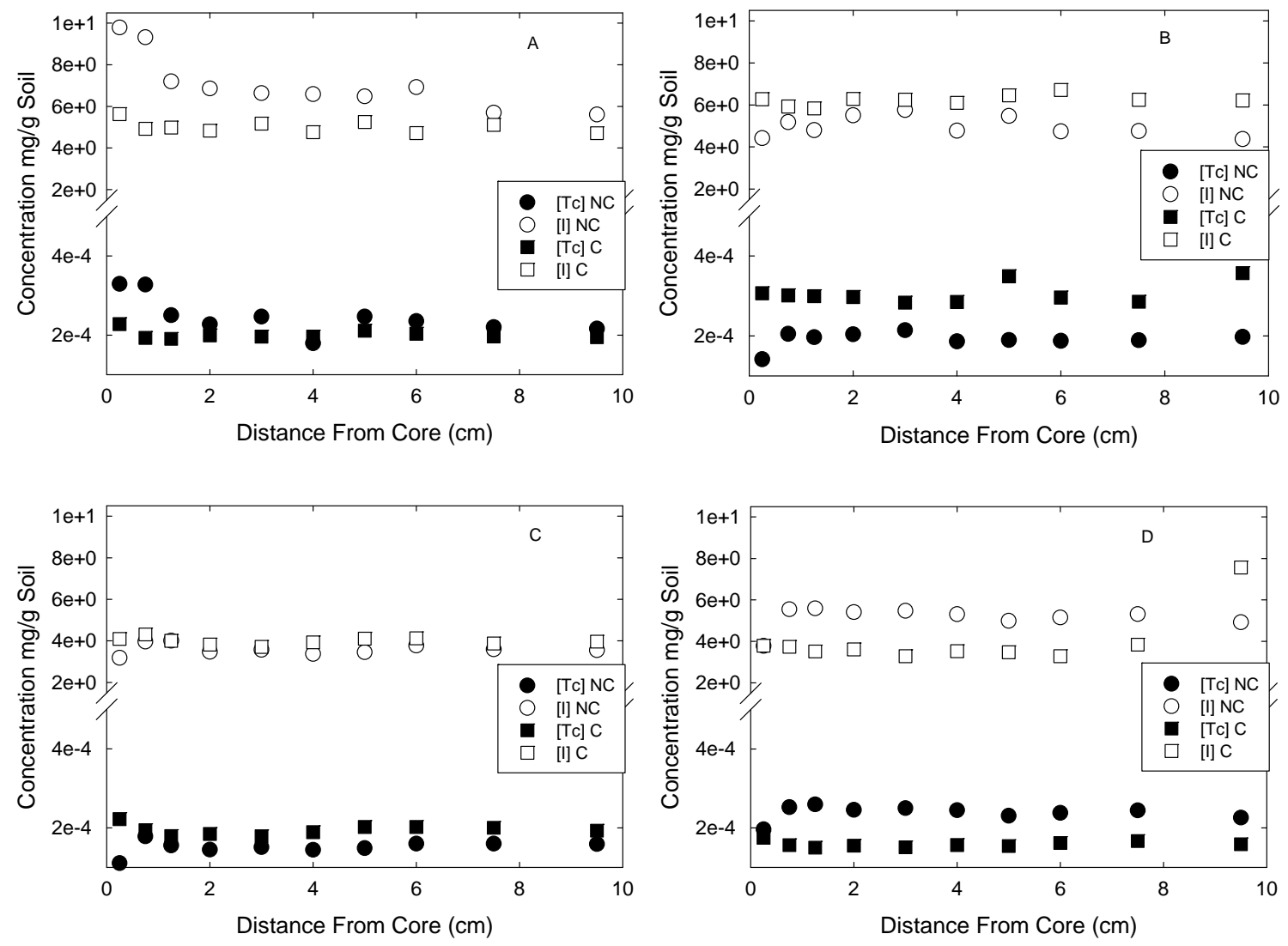

Figure 9.3. Tc and I soil concentration profiles. Top left: $15 \%$ soil moisture, $0 \%$ Fe; Top right: $15 \%$ soil moisture, $4 \%$ Fe; Bottom left: $15 \%$ soil moisture, $8 \%$ Fe; Bottom right: $15 \%$ soil moisture, $12 \% \mathrm{Fe}$.

In contrast, well-developed I and Tc concentration gradients from the interfaces were observed in concrete half cells. Therefore, these concentration gradients were linearized by probit analyses to allow calculation of diffusion coefficients. In concrete half cells in contact with spiked soil-cells at $4 \%$ moisture content, the carbonation of concrete treatment seemed to significantly reduce the diffusivity of both I and Tc (Figure 9.4). Tc and I diffusivities in both the uncarbonated and carbonated half cells seem to be noticeably attenuated by the presence of Fe particles.

In concrete half cells in contact with soil at 7\% moisture content, reduction of diffusivity of both Tc and I were also observed in carbonated specimens (Figure 9.5). Additionally, in most cases, the presence of Fe seemed to exert a more pronounced influence in attenuating the diffusion of Tc and I in concrete. While such attenuation of Tc diffusivity can be ascribed to probable Tc reduction by metallic Fe, it is unclear how the metallic Fe may be contributing towards reduction in iodide mobility.

In carbonated concrete specimens in contact with high moisture content (15\%) soils, similar reductions in Tc and I were also observed (Figure 9.6). In both uncarbonated and carbonated concrete specimens, the presence of metallic Fe significantly reduced the diffusivity of both Tc and I.

Probit analysis of these set of data is presented in Figures 9.9-9.14. 

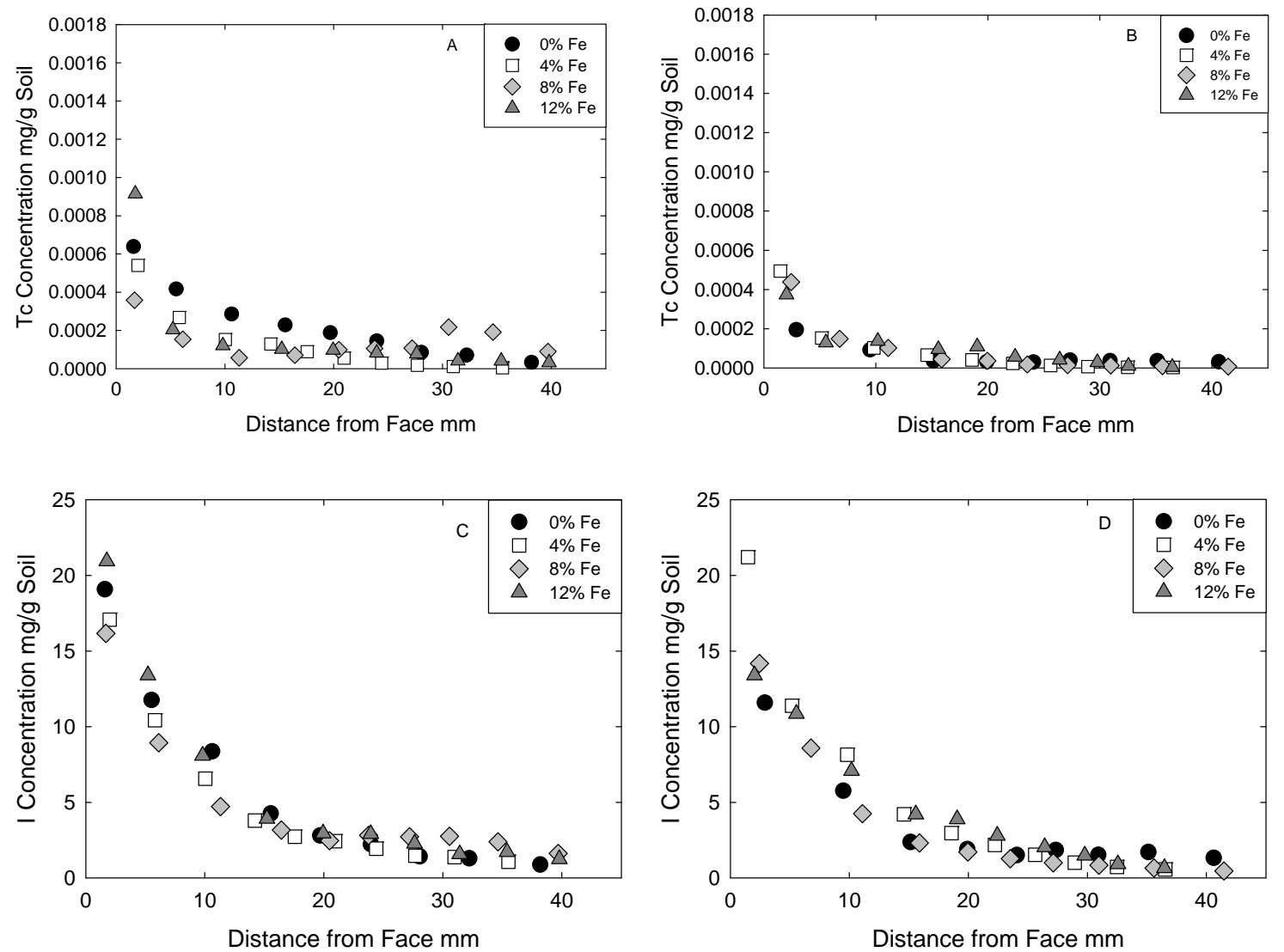

Figure 9.4. Concrete half-cell concentration profiles as a function of iron content: Top left: Tc concentration for non-carbonated concrete at 4\% soil moisture; Top right: Tc concentration for carbonated concrete at $4 \%$ soil moisture; Bottom left: I concentration for non-carbonated concrete at $4 \%$ soil moisture; Bottom right: I concentration for carbonated concrete at $4 \%$ soil moisture. 

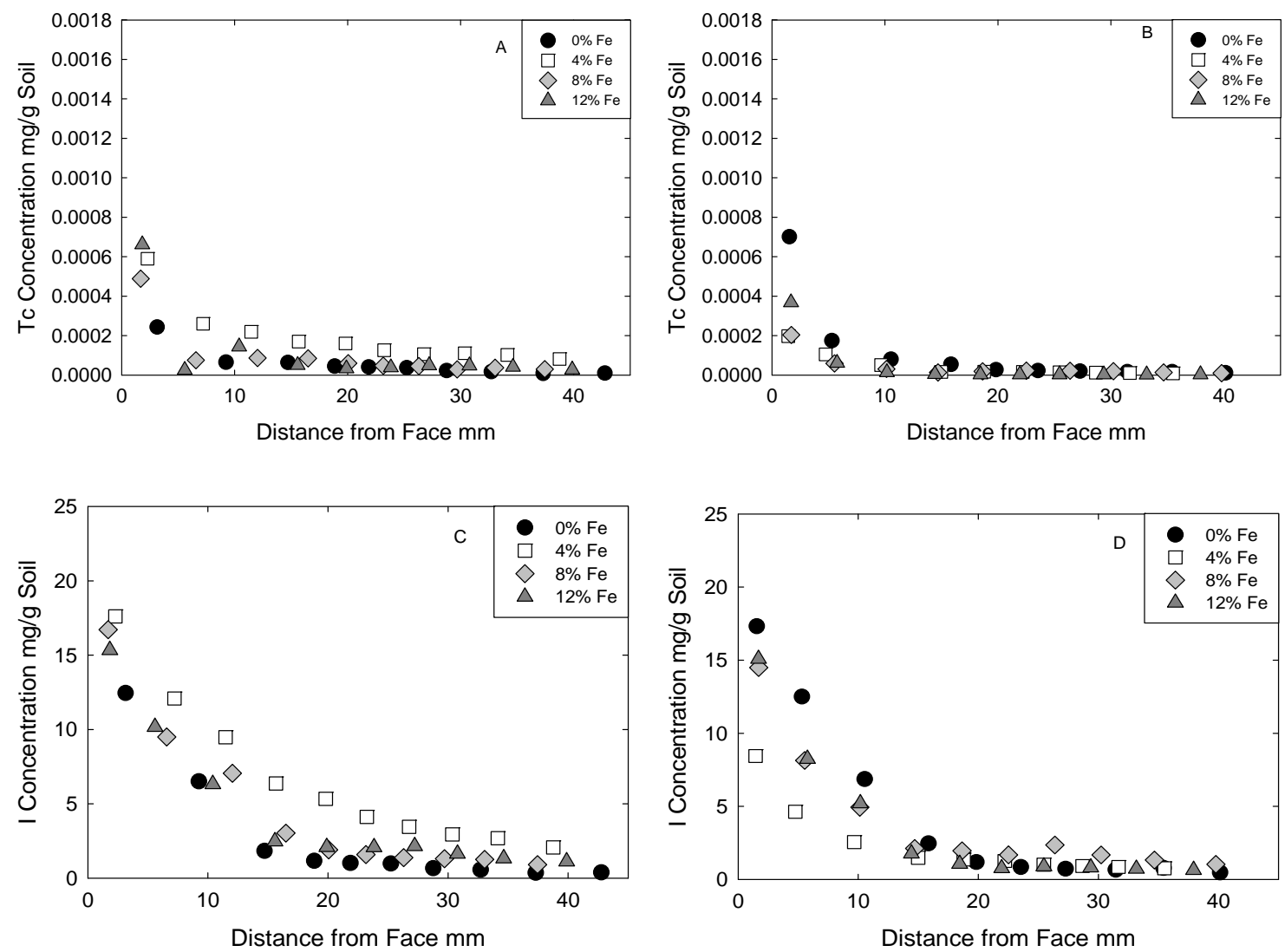

Figure 9.5. Concrete half-cell concentration profiles as a function of iron content. Top left: Tc concentration for non-carbonated concrete at 7\% soil moisture; Top right: Tc concentration for carbonated concrete at 7\% soil moisture; Bottom left: I concentration for non-carbonated concrete at 7\% soil moisture; Bottom right: d) I concentration for carbonated concrete at $7 \%$ soil moisture. 

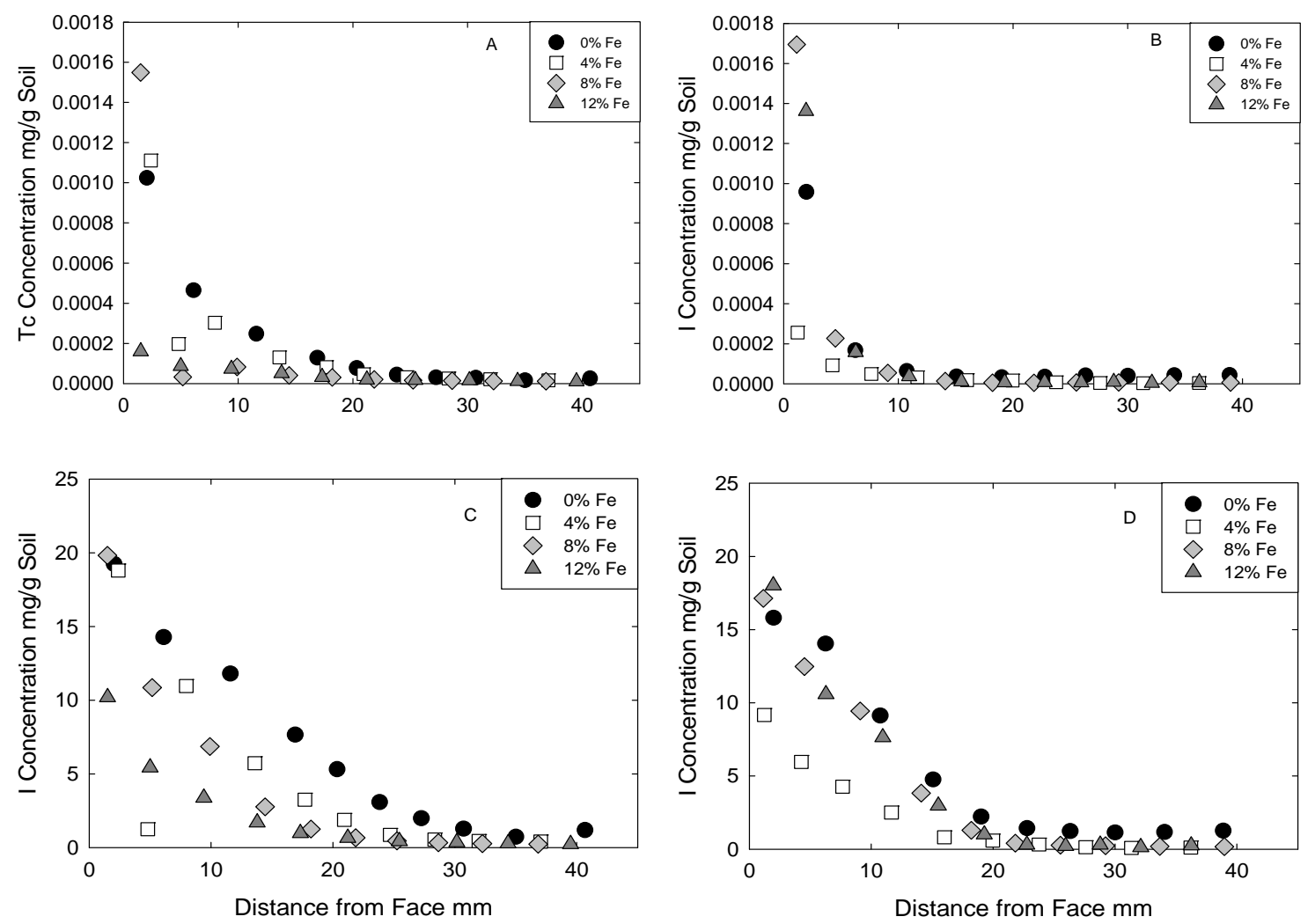

Figure 9.6. Concrete half-cell concentration profiles as a function of iron content. Top left: Tc concentration for non-carbonated concrete at $15 \%$ soil moisture; Top right: Tc concentration for carbonated concrete at $15 \%$ soil moisture; Bottom left: I concentration for noncarbonated concrete at $15 \%$ soil moisture; Bottom right: I concentration for carbonated concrete at $15 \%$ soil moisture.

A set of diffusion experiments was conducted using concrete-soil half cells containing Tc. Concrete half-cell specimens were spiked with Tc to achieve a measurable diffusion profile in the soil part of the half-cell. The characteristics of the specimens used are listed in Table 9.3.

Table 9.2. Characteristics of cement specimens used in concrete-soil half-cell tests

\begin{tabular}{ccccccc}
\hline $\begin{array}{c}\text { Concrete Core } \\
\text { ID }\end{array}$ & $\begin{array}{c}\text { Fe Content } \\
\text { in Concrete } \\
(\mathrm{wt} \%)\end{array}$ & $\begin{array}{c}\text { Tc } \\
\text { Concentration } \\
(\mu \mathrm{g} / \mathrm{g} \text { concrete })\end{array}$ & $\begin{array}{c}\text { Height of } \\
\text { Half Cell } \\
(\mathrm{cm})\end{array}$ & $\begin{array}{c}\text { Volume of } \\
\text { Half Cell } \\
\left(\mathrm{cm}^{3}\right)\end{array}$ & $\begin{array}{c}\text { Bulk } \\
\text { Density } \\
\left(\mathrm{g} / \mathrm{cm}^{3}\right)\end{array}$ & $\begin{array}{c}\text { Initial Soil } \\
\text { Moisture } \\
\text { Content (\%) }\end{array}$ \\
\hline Tc-C-4-0-204 & 0 & 74 & 4.17 & 61.05 & 2.04 & - \\
Tc-C-4-4-213 & 4 & 74 & 4.26 & 62.20 & 2.23 & - \\
Tc-C-4-0-203 & 0 & 78 & 4.34 & 63.39 & 2.07 & - \\
Tc-C-4-4-212 & 4 & 82 & 4.23 & 61.77 & 2.23 & - \\
Tc-C-4-0-202 & 0 & 79 & 4.39 & 64.18 & 2.08 & - \\
Tc-C-4-4-211 & 4 & 84 & 4.37 & 63.82 & 2.23 & - \\
\hline \multicolumn{7}{c}{ Soil Half-Cells } \\
\hline
\end{tabular}




\begin{tabular}{lllllll}
\hline Tc-C-4-0-204 & - & 0 & 11.16 & 239.83 & 1.39 & 4 \\
Tc-C-4-4-213 & - & 0 & 11.11 & 238.68 & 1.44 & 4 \\
Tc-C-4-0-203 & - & 0 & 11.05 & 237.48 & - & 7 \\
Tc-C-4-4-212 & - & 0 & 11.13 & 239.11 & - & 7 \\
Tc-C-4-0-202 & - & 0 & 11.01 & 236.69 & - & 15 \\
Tc-C-4-4-211 & - & 0 & 11.03 & 237.06 & - & 15 \\
\hline
\end{tabular}

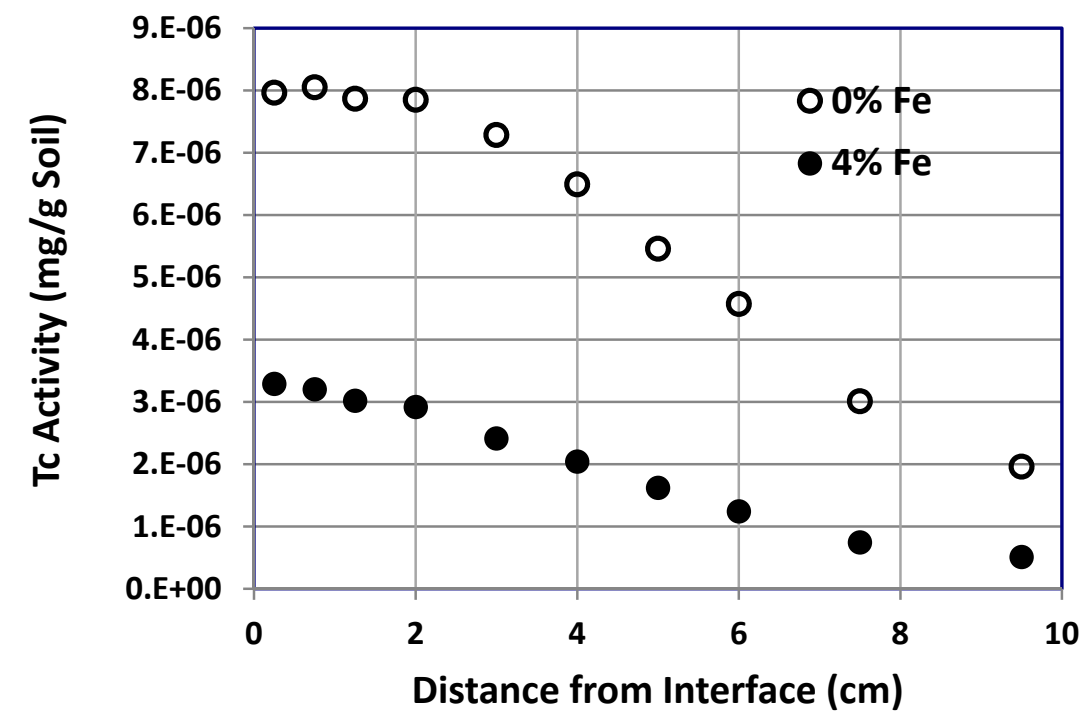

Figure 9.7. Tc Concentration Profiles in soil half cells

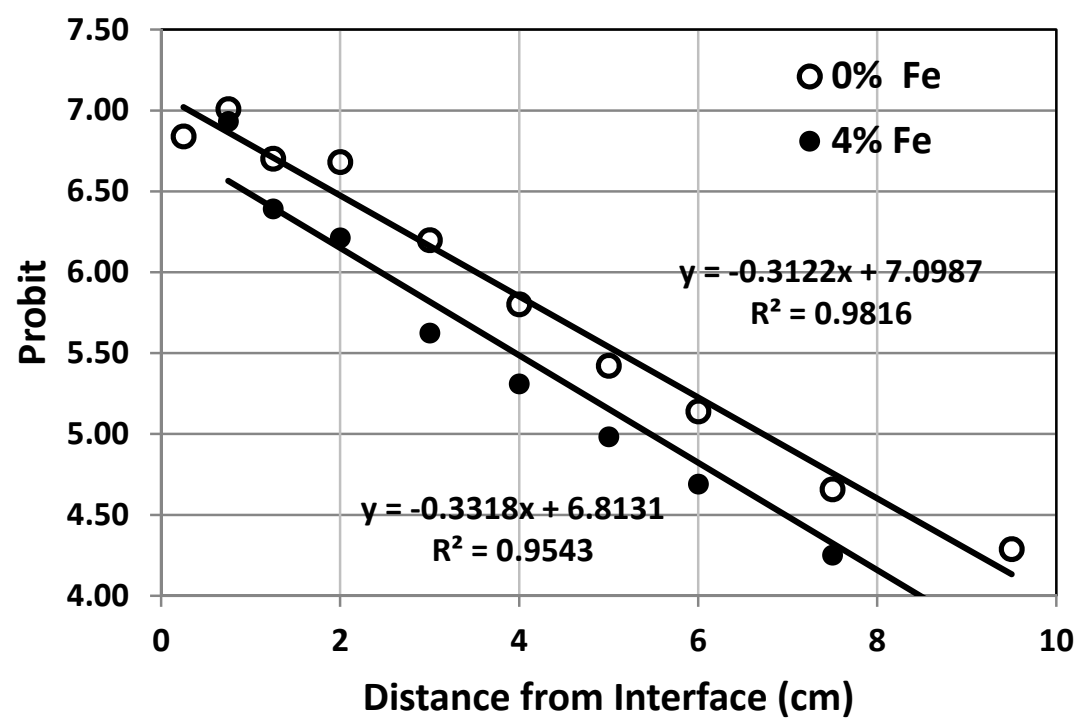

Figure 9.8. Probit analysis for Tc in soil half cells

The diffusion profiles reported previously indicated that except for the low moisture soil cores, the diffusion of Tc had proceeded to near-equilibrium conditions in that no concentration gradients from the concrete-soil interface were present. Comparatively, in the low moisture cores (initial $4 \%$, final $\sim 1 \%$ )) distinct Tc concentration gradients were observed from the interface. The data indicated that adding 4\% 
metallic iron attenuates the release of Tc from the concrete cores. Concrete core with $4 \%$ metallic iron released a total of $\sim 8 \times 10^{-4} \mathrm{mg}$ of Tc in to the soil, whereas, the concrete core without added iron released $\sim 1.6 \times 10^{-3} \mathrm{mg}$ of Tc in to the soil half cell. Thus about $50 \%$ reduction in Tc release from $4 \%$ iron containing concrete core can be attributed to potential reduction of $\mathrm{Tc}(\mathrm{VII})$ to $\mathrm{Tc}(\mathrm{IV})$ by the metallic iron particles.

Therefore the Tc diffusion calculations using Probit analyses were conducted using data from the two soil cores containing $4 \%$ moisture content with and without $4 \%$ by mass iron particles. The resulting Probit plots are shown in Figure 9.8 and the data is also tabulated (Table 9.4). The Tc diffusion coefficient for core 204 without iron particles was $1.2 \times 10^{-9} \mathrm{~cm}^{2} / \mathrm{s}$, whereas for the core 213 containing $4 \%$ by mass iron particles, the Tc diffusion coefficient was found to be $1.1 \times 10^{-9} \mathrm{~cm}^{2} / \mathrm{s}$. These data indicated that the presence of iron particles ( $4 \%$ by mass) did not significantly affect Te diffusivity in soils with $\sim 4 \%$ initial moisture content. Similar comparisons of Tc diffusivities in soils with higher moisture contents ( 7 and 15\%) could not be made to due to near equilibrium diffusion of Tc that resulted in lack of concentration gradients.

Table 9.3. Diffusivity analysis of Tc in soil cores

\begin{tabular}{ccccc}
\hline Core ID & Initial MC wt $\%$ & Carbonation & Fe wt $\%$ & Tc Diffusivity cm ${ }^{2} / \mathrm{s}$ \\
\hline Tc-C-4-0-204 & 4 & $\mathrm{~N}$ & 0 & $1.2 \mathrm{E}-09$ \\
Tc-C-4-4-213 & 4 & $\mathrm{~N}$ & 4 & $1.1 \mathrm{E}-09$ \\
\hline
\end{tabular}



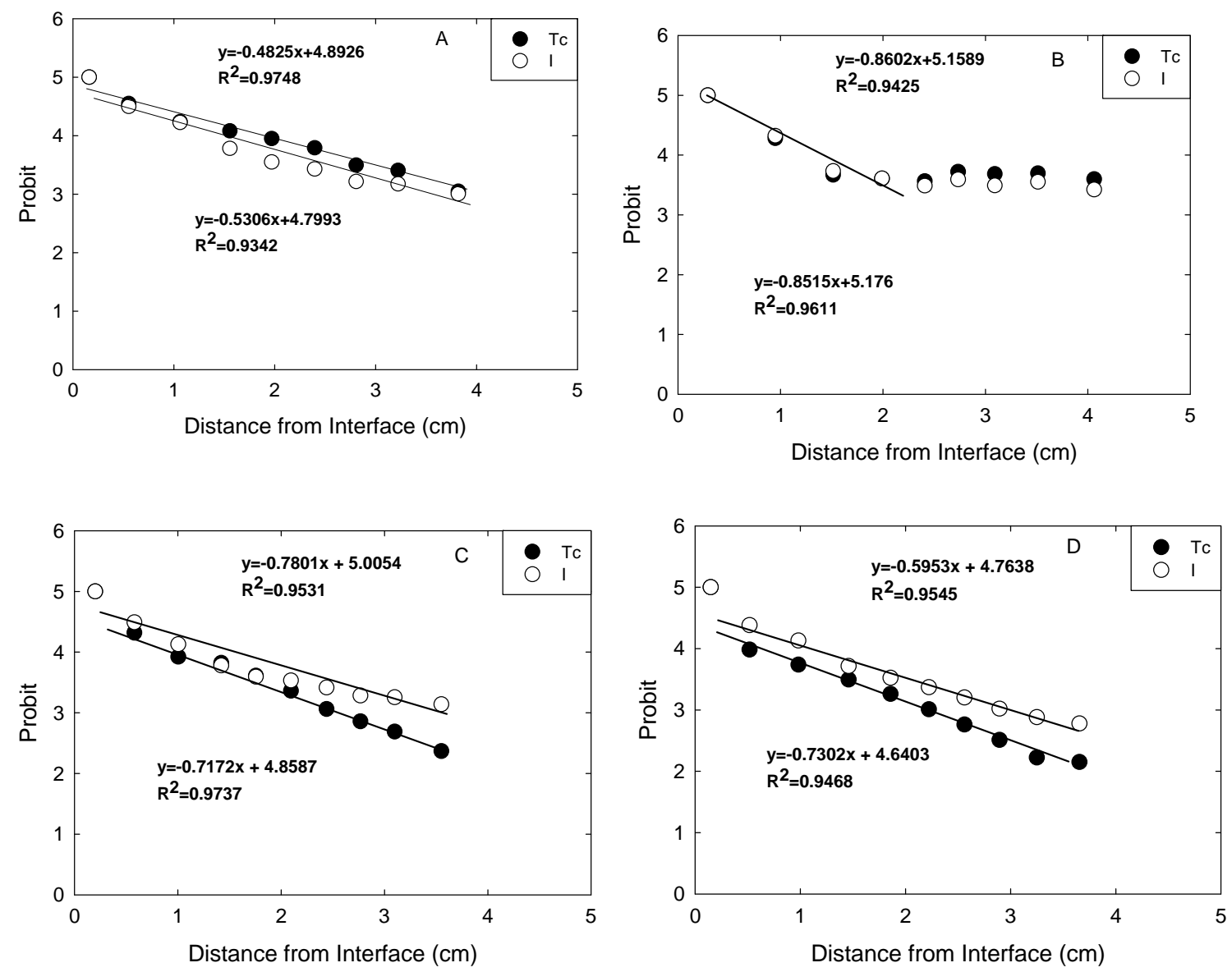

Figure 9.9. Probit analysis of Tc in concrete cores. Top left: $4 \%$ moisture content, no Fe, no carbonation; Top right: 4\% moisture content, no Fe, carbonated; Bottom left: 4\% moisture content, $4 \% \mathrm{Fe}$, no carbonation; Bottom right: $4 \%$ moisture content, $4 \% \mathrm{Fe}$, carbonated.

The results of probit analyses are shown in figure 9.9 through 9.14, and the resulting diffusivities are tabulated (Table 9.5). Overall, the calculated diffusivities for Tc ranged from $1.9 \times 10^{-9}$ to $1 \times 10^{-10} \mathrm{~cm}^{2} / \mathrm{s}$, and I ranged from $2.3 \times 10^{-9}$ to $3.1 \times 10^{-10} \mathrm{~cm}^{2} / \mathrm{s}$. The highest Tc and I diffusivities were observed in all uncarbonated, Fe-free concrete cores contacting spiked soils at all three moisture contents $(4 \%, 7 \%$, and $15 \%$ ). However, the diffusivities of both Tc and I (except in one case) were significantly attenuated in all carbonated concrete cores. The reduction of Tc diffusivities ranged from $55 \%$ to $72 \%$. Meanwhile, I diffusivities were reduced by $61 \%$ at soil moisture content of $4 \%$ and by $58 \%$ at soil moisture content of $15 \%$. However, I diffusivity showed an anomalous increase of $\sim 38 \%$ in an uncarbonated, Fe-free concrete core in contact with a soil core with $7 \%$ moisture content. 

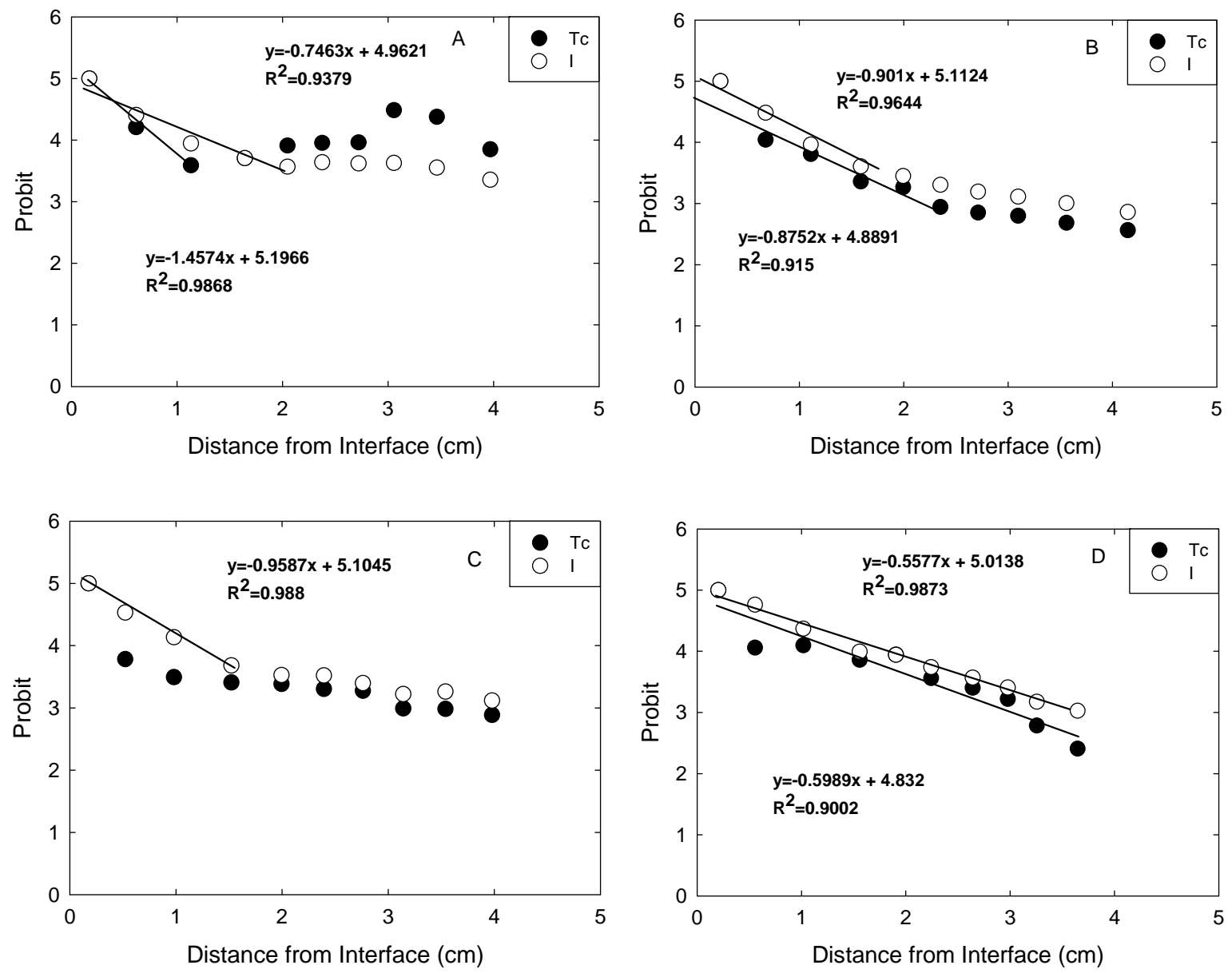

Figure 9.10. Probit analysis of Tc in concrete cores. Top left: $4 \%$ moisture content, $8 \% \mathrm{Fe}$, no carbonation; Top right: $4 \%$ moisture content, $8 \%$ Fe, carbonated; Bottom left: $4 \%$ moisture content, $12 \% \mathrm{Fe}$, no carbonation; Bottom right: $4 \%$ moisture content, $12 \% \mathrm{Fe}$, carbonated. 

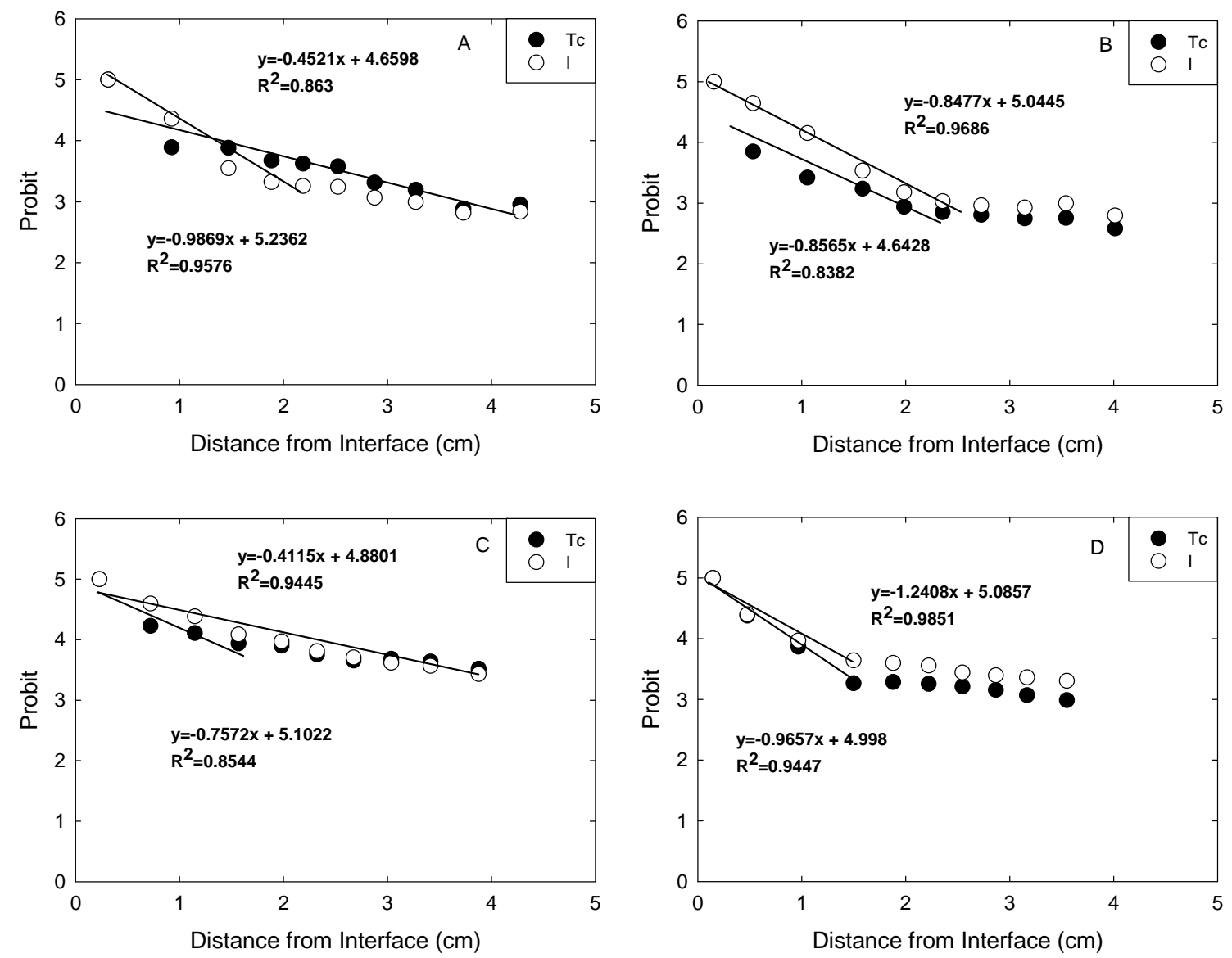

Figure 9.11. Probit analysis of Tc in concrete cores. Top left: 7\% moisture content, no Fe, no carbonation; Top right: 7\% moisture content, no Fe, carbonated; Bottom left: 7\% moisture content, $4 \% \mathrm{Fe}$, no carbonation; Bottom right: 7\% moisture content, $4 \% \mathrm{Fe}$, carbonated. 

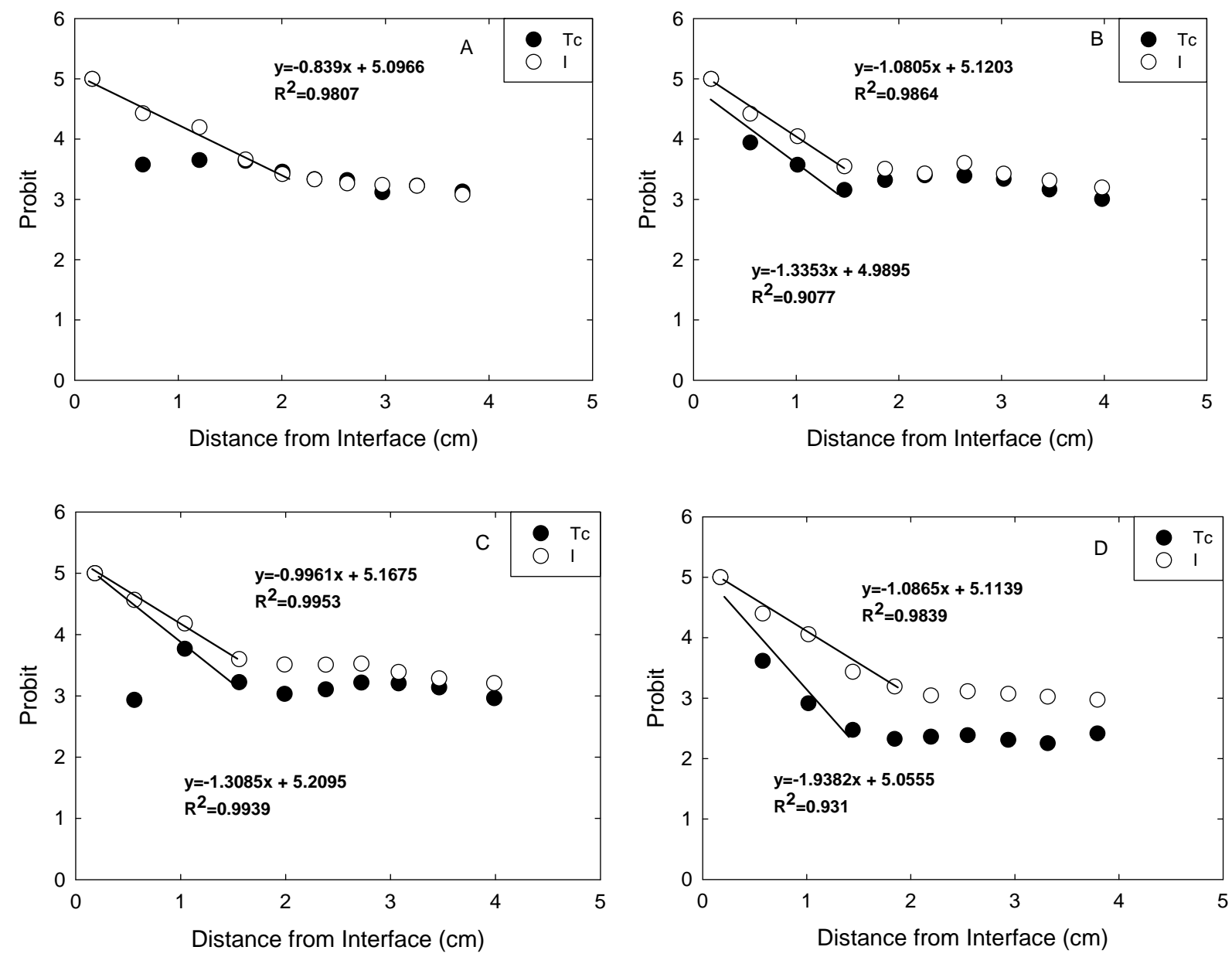

Figure 9.12. Probit analysis of Tc in concrete cores. Top left: $7 \%$ moisture content, $8 \% \mathrm{Fe}$, no carbonation; Top right: $7 \%$ moisture content, $8 \% \mathrm{Fe}$, carbonation; Bottom left: $7 \%$ moisture content, $12 \% \mathrm{Fe}$, no carbonation; Bottom right: 7\% moisture content, $12 \% \mathrm{Fe}$, carbonation. 

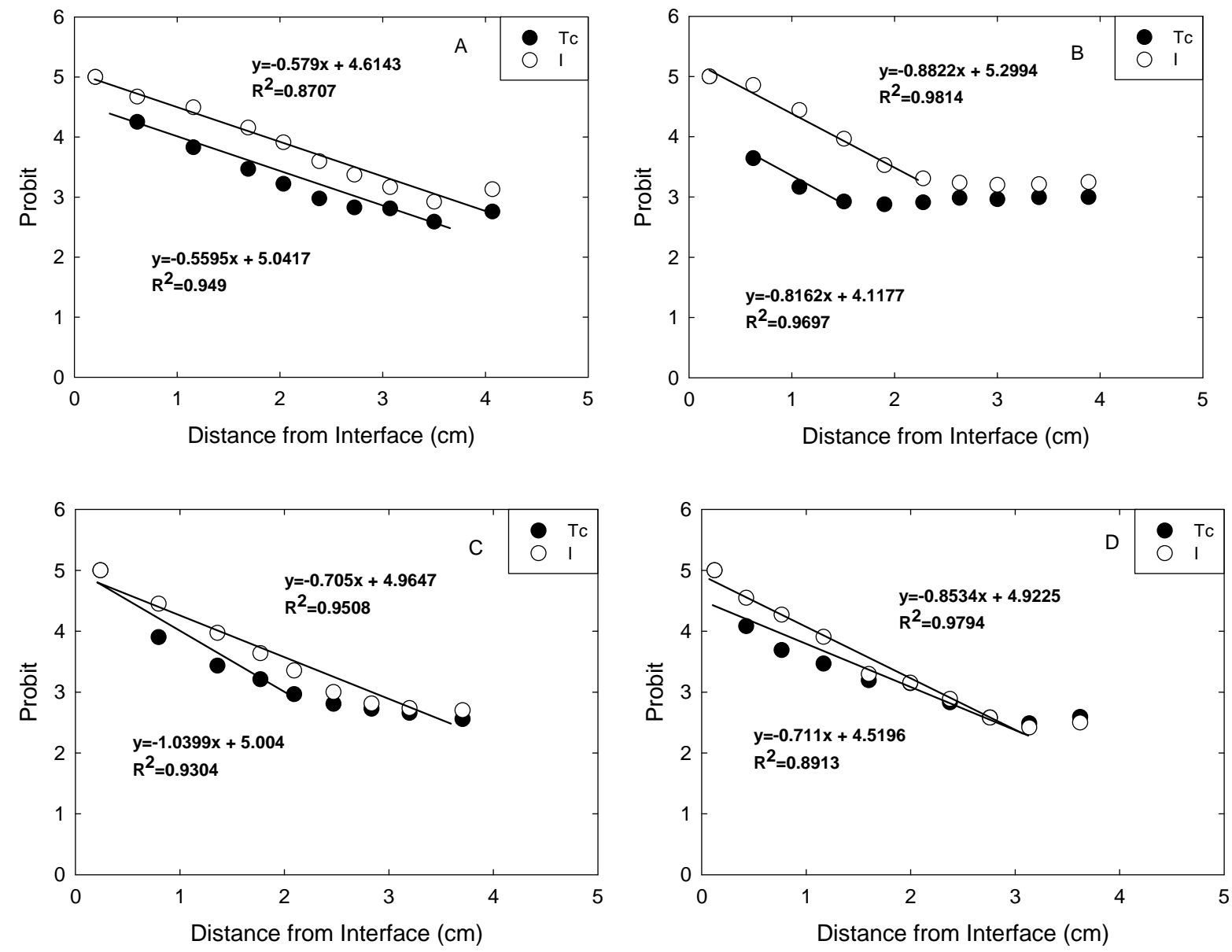

Figure 9.13. Probit analysis of Tc in concrete cores. Top left: $15 \%$ moisture content, no Fe, no carbonation; Top right: 15\% moisture content, no Fe, carbonation; Bottom left: $15 \%$ moisture content, $4 \% \mathrm{Fe}$, no carbonation; Bottom right: $15 \%$ moisture content, $4 \% \mathrm{Fe}$, carbonation Tc-C-08-3-4-360. 

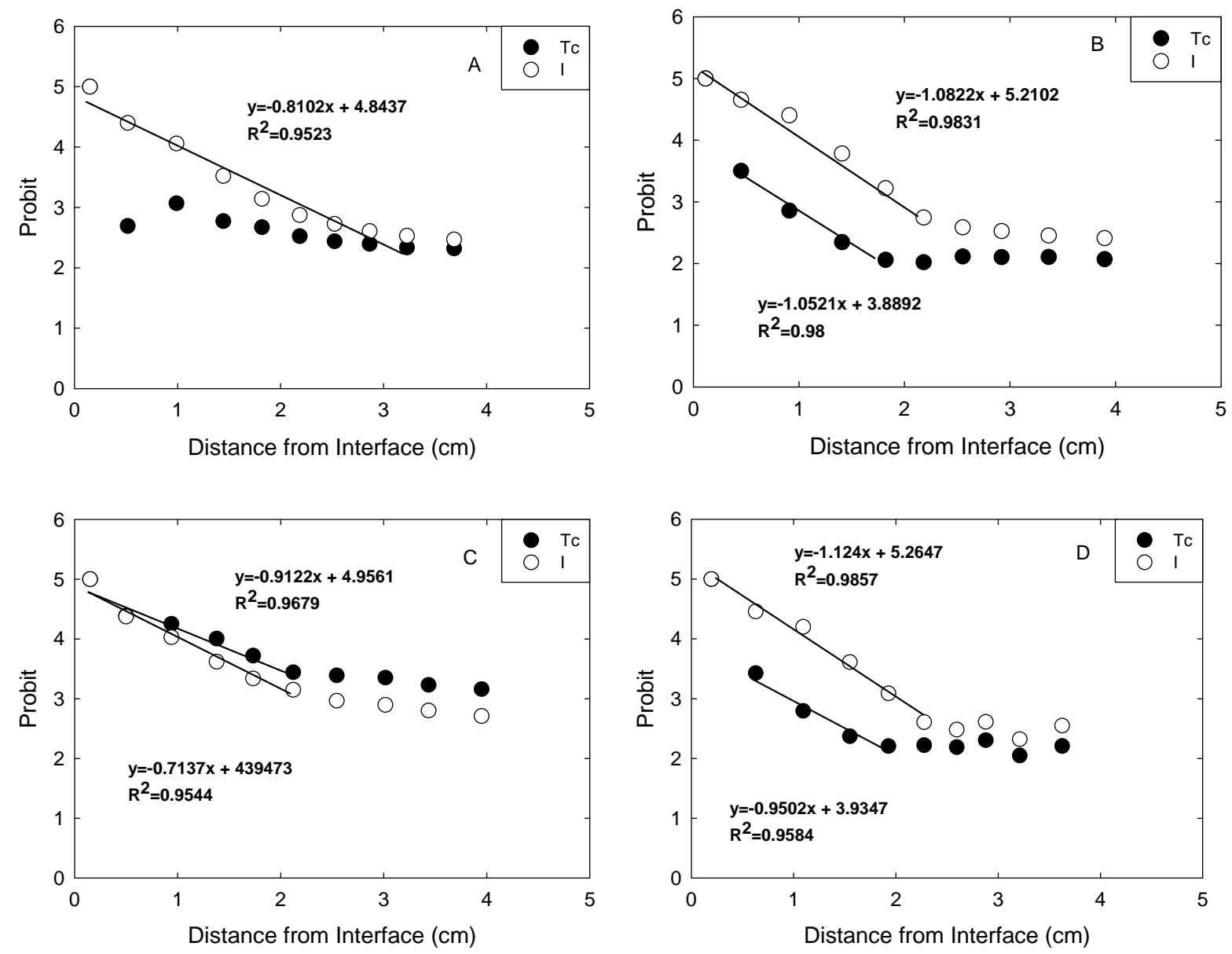

Figure 9.14. Probit analysis of Tc in concrete cores. Top left $15 \%$ moisture content, $8 \% \mathrm{Fe}$, no carbonation; Top right: $15 \%$ moisture content, $8 \% \mathrm{Fe}$, carbonated; Bottom left: $15 \%$ moisture content, $12 \% \mathrm{Fe}$, no carbonation; Bottom right: $15 \%$ moisture content, $12 \% \mathrm{Fe}$, carbonation.

Table 9.4. Diffusivity of Tc and I in concrete half cells

\begin{tabular}{cccccc}
\hline Core ID & $\begin{array}{c}\text { Initial Moisture } \\
\text { Content (Wt \%) }\end{array}$ & Carbonation & $\begin{array}{c}\mathrm{Fe} \\
(\mathrm{wt} \%)\end{array}$ & $\begin{array}{c}\text { Tc Diffusivity } \\
\left(\mathrm{cm}^{2} / \mathrm{s}\right)\end{array}$ & $\begin{array}{c}\text { I Diffusivity } \\
\left(\mathrm{cm}^{2} / \mathrm{s}\right)\end{array}$ \\
\hline Tc-C-08-3-0-325 & 4 & $\mathrm{~N}$ & 0 & $1.7 \mathrm{E}-09$ & $1.4 \mathrm{E}-09$ \\
Tc-C-08-3-0-329 & 7 & $\mathrm{~N}$ & 0 & $1.9 \mathrm{E}-09$ & $4.0 \mathrm{E}-10$ \\
Tc-C-08-3-0-330 & 15 & $\mathrm{~N}$ & 0 & $1.3 \mathrm{E}-09$ & $1.2 \mathrm{E}-09$ \\
Tc-C-08-3-0-332 & 4 & $\mathrm{Y}$ & 0 & $5.3 \mathrm{E}-10$ & $5.4 \mathrm{E}-10$ \\
Tc-C-08-3-0-333 & 7 & $\mathrm{Y}$ & 0 & $5.4 \mathrm{E}-10$ & $5.5 \mathrm{E}-10$ \\
Tc-C-08-3-0-334 & 15 & $\mathrm{Y}$ & 0 & $5.9 \mathrm{E}-10$ & $5.1 \mathrm{E}-10$ \\
Tc-C-08-3-4-350 & 4 & $\mathrm{~N}$ & 4 & $7.7 \mathrm{E}-10$ & $6.5 \mathrm{E}-10$ \\
Tc-C-08-3-4-351 & 7 & $\mathrm{~N}$ & 4 & $6.9 \mathrm{E}-10$ & $2.3 \mathrm{E}-09$ \\
Tc-C-08-3-4-353 & 15 & $\mathrm{~N}$ & 4 & $3.6 \mathrm{E}-10$ & $7.9 \mathrm{E}-10$ \\
Tc-C-08-3-4-357 & 4 & $\mathrm{Y}$ & 4 & $7.4 \mathrm{E}-10$ & $1.1 \mathrm{E}-09$ \\
\hline
\end{tabular}




\begin{tabular}{cccccc}
\hline Tc-C-08-3-4-359 & 7 & Y & 4 & $2.6 \mathrm{E}-10$ & $4.2 \mathrm{E}-10$ \\
Tc-C-08-3-4-360 & 15 & Y & 4 & $7.8 \mathrm{E}-10$ & $5.4 \mathrm{E}-10$ \\
Tc-C-08-3-8-401 & 4 & N & 8 & $1.9 \mathrm{E}-10$ & $7.1 \mathrm{E}-10$ \\
Tc-C-08-3-8-402 & 7 & N & 8 & $(a)$ & $5.6 \mathrm{E}-10$ \\
Tc-C-08-3-8-403 & 15 & N & 8 & $(a)$ & $6.0 \mathrm{E}-10$ \\
Tc-C-08-3-8-407 & 4 & $\mathrm{Y}$ & 8 & $5.1 \mathrm{E}-10$ & $4.9 \mathrm{E}-10$ \\
Tc-C-08-3-8-409 & 7 & $\mathrm{Y}$ & 8 & $2.2 \mathrm{E}-10$ & $3.4 \mathrm{E}-10$ \\
Tc-C-08-3-8-410 & 15 & $\mathrm{Y}$ & 8 & $3.6 \mathrm{E}-10$ & $3.4 \mathrm{E}-10$ \\
Tc-C-08-3-12-425 & 4 & $\mathrm{~N}$ & 12 & $(\mathrm{a})$ & $4.3 \mathrm{E}-10$ \\
Tc-C-08-3-12-426 & 7 & $\mathrm{~N}$ & 12 & $2.3 \mathrm{E}-10$ & $4.0 \mathrm{E}-10$ \\
Tc-C-08-3-12-427 & 15 & $\mathrm{~N}$ & 12 & $4.7 \mathrm{E}-10$ & $7.7 \mathrm{E}-10$ \\
Tc-C-08-3-12-432 & 4 & $\mathrm{Y}$ & 12 & $1.1 \mathrm{E}-10$ & $1.3 \mathrm{E}-10$ \\
Tc-C-08-3-12-433 & 7 & $\mathrm{Y}$ & 12 & $1.0 \mathrm{E}-10$ & $3.3 \mathrm{E}-10$ \\
Tc-C-08-3-12-435 & 15 & $\mathrm{Y}$ & 12 & $4.4 \mathrm{E}-10$ & $3.1 \mathrm{E}-10$ \\
\hline
\end{tabular}

(a) Probit analysis could not be performed due to poorly defined diffusion profile

Similar attenuation in Tc and I diffusivities were also observed in carbonated concrete half cells containing various quantities of Fe. The diffusivities of Tc showed reduction typically ranging from 25 to $81 \%$, except enhanced diffusivities ( 40 - 30\%) were observed in two concrete cores containing $4 \% \mathrm{Fe}$ and in contact with soil with 4 and $15 \%$ moisture contents. In these same cores, similar increases in I diffusivities were also observed ( 100 - 6\%). However all other Fe-containing carbonated concrete cores exhibited reduction in I diffusivities that ranged from $9 \%$ to $76 \%$.

In summary, these data showed that:

- Noticeable attenuation of ${ }^{99} \mathrm{Tc}$ and I diffusivities occurred in concrete half cells that were carbonated using sodium carbonate solution.

- Generally, addition of Fe particles to both uncarbonated and carbonated concrete also results in significant reduction in Tc and I diffusivities.

- Based on previous studies, attenuation of Tc diffusivities upon addition of Fe can be attributable to a reduction of $\mathrm{Tc}(\mathrm{VII})$ to relatively insoluble Tc(IV) solid forms, whereas mechanisms of similar attenuation of I diffusivity upon addition of Fe need further investigation. 


\subsection{Diffusion of lodine, Rhenium, and Technetium from Soil into Fractured Concrete}

A set of diffusion experiments were initiated using fractured concrete-soil half cells to assess the effect of fractures within the concrete monolith. Concrete monoliths were encased in shrinkwrap and struck with a hammer to prevent the formation of rubble. Each fractured core possessed a single fracture extending the length of the core, perpendicular to the concrete-sediment interface.

In one set of experiments, soil half-cell specimens were spiked with I and Re to achieve a measurable diffusion in the fractured concrete part of the half-cell. The characteristics of the specimens used are listed in Table 10.1. The diffusion tests were conducted under unsaturated conditions at 4\%, 7\%, and $15 \%$ (moisture content by weight) with or without Fe addition (4 wt \%) and carbonation.

In a second set of experiments, Tc-spiked soil half cells at a fixed moisture content were contacted with fractured concrete half cells. The characteristics of these fractured concrete half cells are listed in Table 10.2.

Table 10.1. Characteristics of cement half cells used in fractured concrete-soil half-cell tests (Re and I)

\begin{tabular}{lccccccccc}
\hline & \multicolumn{3}{c}{$\begin{array}{c}\text { Surface } \\
\text { Specimen }\end{array}$ No. } & $\begin{array}{c}\text { Length } \\
(\mathrm{cm})\end{array}$ & $\begin{array}{c}\text { Diameter } \\
(\mathrm{cm})\end{array}$ & $\begin{array}{c}\text { Area } \\
\left(\mathrm{cm}^{2}\right)\end{array}$ & $\begin{array}{c}\text { Volume } \\
\left(\mathrm{cm}^{3}\right)\end{array}$ & $\begin{array}{c}\text { Moisture Content } \\
(\mathrm{wt} \%)\end{array}$ & \multicolumn{3}{c}{ Treatment } \\
\hline C-5-0-2 & 4.15 & 4.33 & 85.89 & 61.10 & $\mathrm{x}$ & & & No & No \\
C-5-4-26 & 3.89 & 4.34 & 82.44 & 57.35 & $\mathrm{x}$ & & & Yes & No \\
C-5-0-1 & 4.15 & 4.33 & 86.04 & 61.25 & $\mathrm{x}$ & & & No & Yes \\
C-5-4-21 & 4.02 & 4.33 & 84.04 & 59.10 & $\mathrm{x}$ & & & Yes & Yes \\
C-5-0-7 & 4.24 & 4.33 & 87.02 & 62.32 & & $\mathrm{x}$ & & No & No \\
C-5-4-27 & 3.98 & 4.34 & 83.75 & 58.77 & & $\mathrm{x}$ & & Yes & No \\
C-5-0-5 & 4.18 & 4.34 & 86.63 & 61.89 & & $\mathrm{x}$ & & No & Yes \\
C-5-4-23 & 4.12 & 4.34 & 85.68 & 60.87 & & $\mathrm{x}$ & & Yes & Yes \\
C-5-0-10 & 4.37 & 4.34 & 89.05 & 64.51 & & & $\mathrm{x}$ & No & No \\
C-5-4-30 & 3.95 & 4.34 & 83.31 & 58.29 & & & $\mathrm{x}$ & Yes & No \\
C-5-0-6 & 4.76 & 4.34 & 94.54 & 70.48 & & & $\mathrm{x}$ & No & Yes \\
C-5-4-24 & 4.52 & 4.34 & 91.26 & 66.91 & & & $\mathrm{x}$ & Yes & Yes \\
\hline
\end{tabular}

Table 10.2. Characteristics of cement half cells used in fractured concrete-soil half-cell tests (Tc)

\begin{tabular}{cccccccccc}
\hline & \multicolumn{1}{c}{ Length } & $\begin{array}{c}\text { Dia. } \\
(\mathrm{cm})\end{array}$ & $\begin{array}{c}\text { Area } \\
(\mathrm{cm})\end{array}$ & $\begin{array}{c}\text { Vol } \\
\left(\mathrm{cm}^{2}\right)\end{array}$ & $\begin{array}{c}\text { Weight } \\
\left(\mathrm{cm}^{3}\right)\end{array}$ & $\begin{array}{c}\text { Density } \\
(\mathrm{g} / \mathrm{cm} 3)\end{array}$ & $\begin{array}{c}\text { Colloida } \\
\text { 1 Iron } \\
(\%)\end{array}$ & $\begin{array}{c}\text { Carbon- } \\
\text { ated }\end{array}$ & $\begin{array}{c}\text { Moisture } \\
\text { Content } \\
(\mathrm{wt} \%)^{(\mathrm{a})}\end{array}$ \\
\hline C-10-5-0-101 & 4.36 & 4.34 & 88.99 & 64.46 & 138.83 & 2.15 & 0 & $\mathrm{~N}$ & 4 \\
C-10-5-0-102 & 4.37 & 4.34 & 89.25 & 64.74 & 139.22 & 2.15 & 0 & $\mathrm{Y}$ & 4 \\
C-10-5-4-105 & 4.28 & 4.34 & 88.00 & 63.37 & 137.39 & 2.17 & 4 & $\mathrm{~N}$ & 4 \\
\hline
\end{tabular}




\begin{tabular}{lllllllllll}
\hline C-10-5-4-106 & 4.25 & 4.34 & 87.52 & 62.86 & 135.92 & 2.16 & 4 & $\mathrm{Y}$ & 4 \\
C-10-5-8-107 & 4.19 & 4.32 & 86.22 & 64.46 & 136.41 & 2.22 & 8 & $\mathrm{~N}$ & 4 \\
C-10-5-8-108 & 4.14 & 4.32 & 85.54 & 60.73 & 134.30 & 2.21 & 8 & $\mathrm{Y}$ & 4 \\
C-10-5-12-110 & 4.23 & 4.32 & 86.79 & 62.07 & 138.96 & 2.24 & 12 & $\mathrm{~N}$ & 4 \\
C-10-5-12-111 & 4.38 & 4.34 & 89.33 & 64.83 & 145.49 & 2.24 & 12 & $\mathrm{Y}$ & 4 \\
\hline
\end{tabular}

(a) Initial moisture content of soil half cells

The results of the probit analysis of these data are shown in Figures $10.1-10.3$ and the diffusivity data is tabulated in Table 10.2.

Overall, the calculated diffusivities for Re ranged from $3.8 \times 10^{-12}$ to $2 \times 10^{-9} \mathrm{~cm}^{2} / \mathrm{s}$ and for I ranged from $1.3 \times 10^{-10}$ to $2.3 \times 10^{-9} \mathrm{~cm}^{2} / \mathrm{s}$ in fractured concrete. The highest Re and I diffusivities were observed in fractured concrete cores that were in contact with spiked soils with $15 \%$ moisture content. Effects of carbonation in enhancing diffusion are noticeable at higher moisture contents ( 7 and 15\%) of the contacting soil. Additions of $4 \%$ by weight Fe did not noticeably affect the diffusivities of Re and I in fractured concrete.
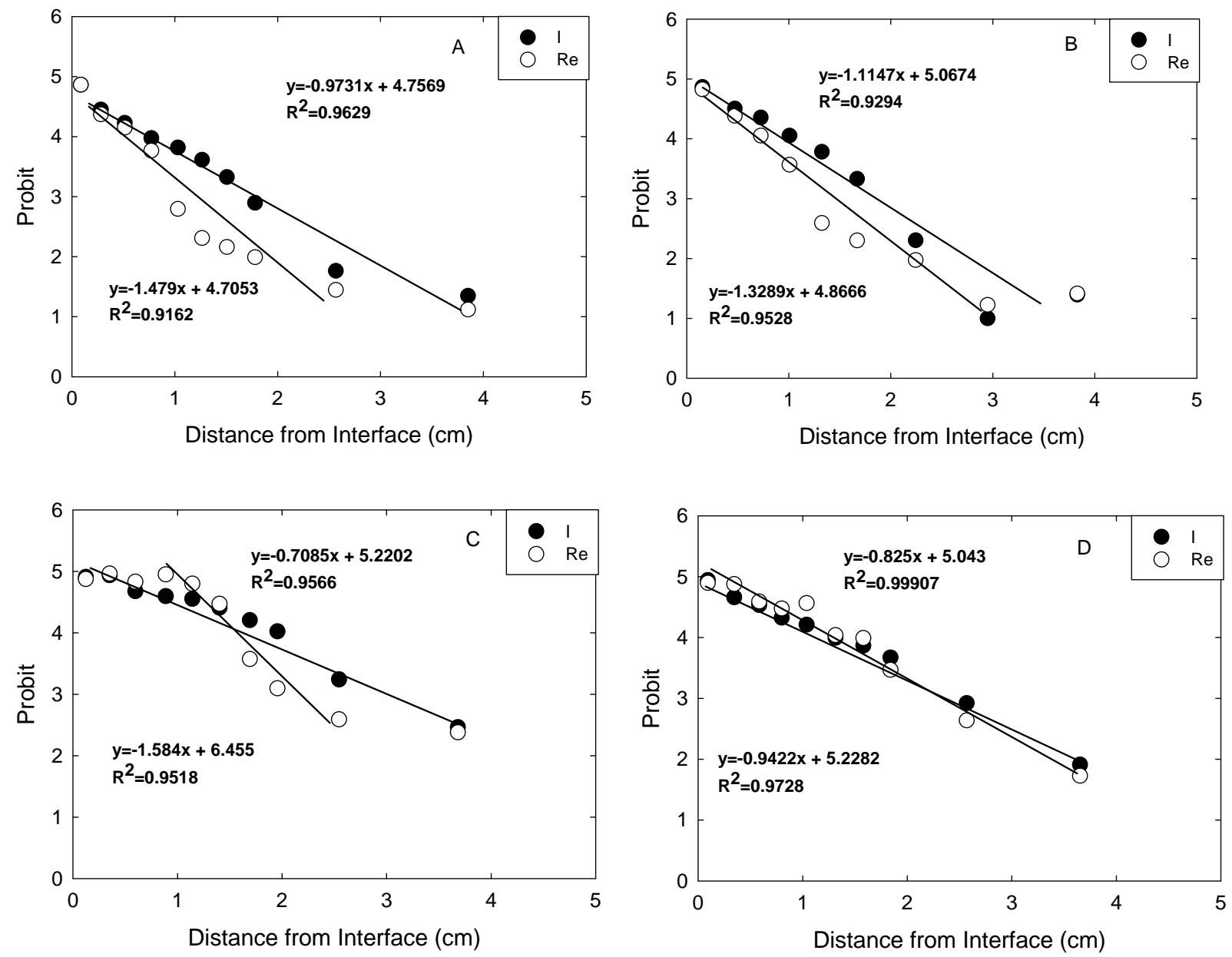

Figure 10.1. Probit plots for concrete cores. Top left: $4 \%$ moisture content, no Fe, no carbonation; Top right: 4\% moisture content, $4 \% \mathrm{Fe}$, no carbonation; Bottom left: $4 \%$ moisture content, no $\mathrm{Fe}$, carbonated; Bottom right: $4 \%$ moisture content, $4 \% \mathrm{Fe}$, carbonated half cells. 

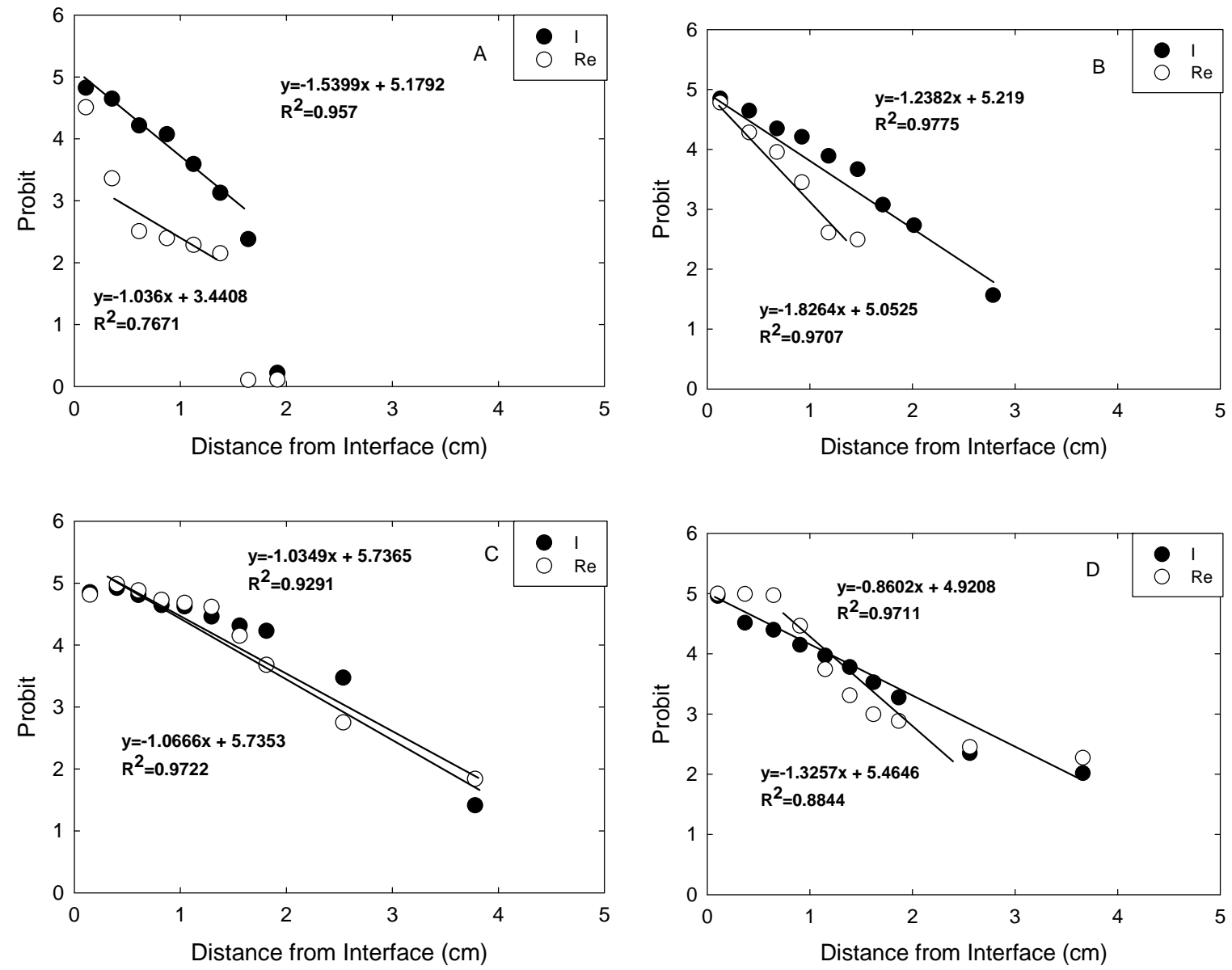

Figure 10.2. Probit plots for concrete cores. Top left: 7\% moisture content, no Fe, no carbonation; Top right: 7\% moisture content, $4 \% \mathrm{Fe}$, no carbonation; Bottom left: 7\% moisture content, no $\mathrm{Fe}$, carbonated; Bottom right: $7 \%$ moisture content, $4 \% \mathrm{Fe}$, carbonated. 

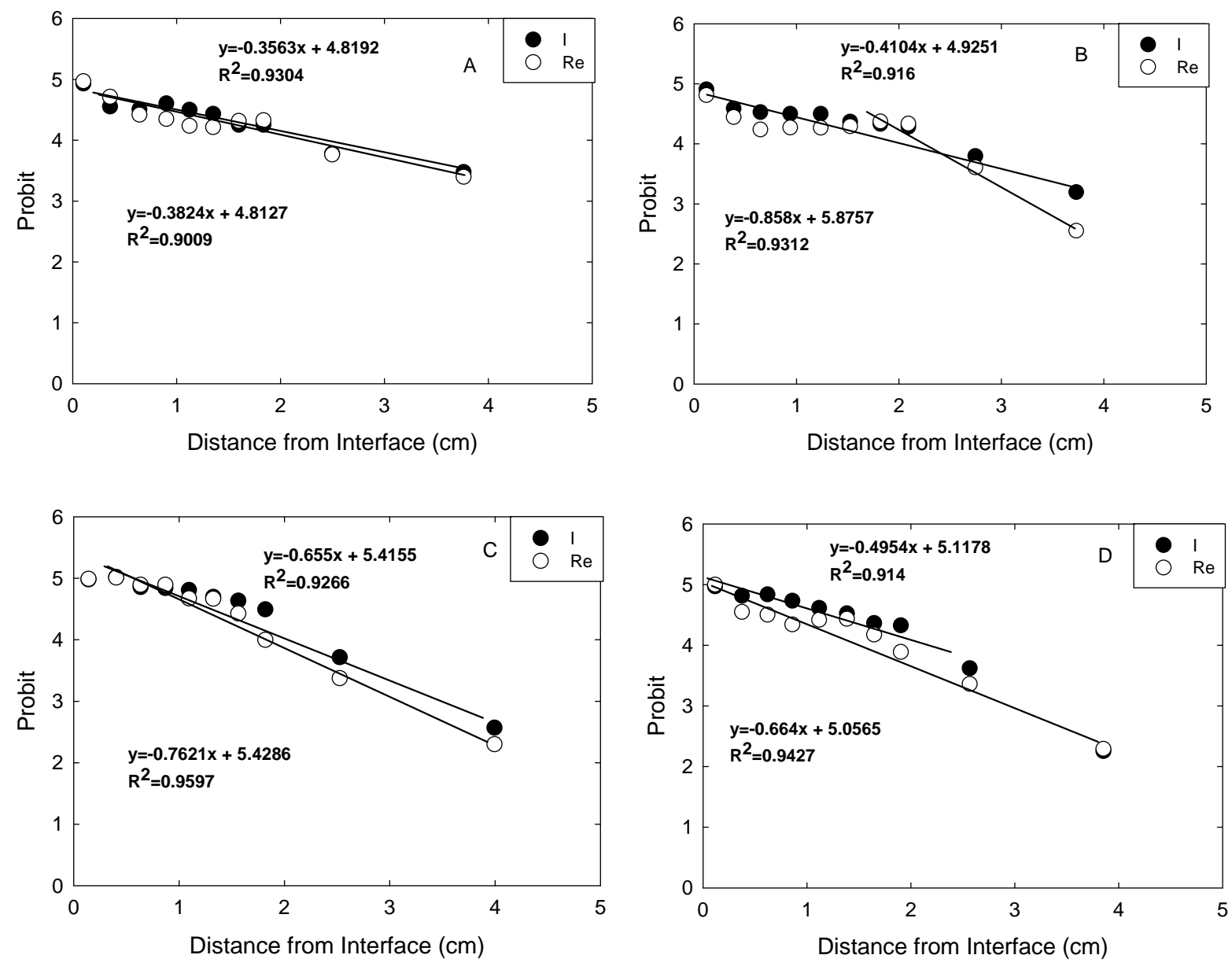

Figure 10.3. Probit plots for concrete cores. Top left: $15 \%$ moisture content, no Fe, no carbonation; Top right: $15 \%$ moisture content, $4 \% \mathrm{Fe}$, no carbonation; Bottom left: $15 \%$ moisture content, no Fe, carbonated; Bottom right: $15 \%$ moisture content, $4 \% \mathrm{Fe}$, carbonated.

The resulting probit plots for Tc diffusivity in concrete cores are shown in Figure 10.4 and Figure 10.5, and the calculated diffusion coefficients are listed in Table 10.8. These values ranged from $3.1 \times 10^{-11} \mathrm{~cm}^{2} / \mathrm{s}$ to $3.6 \times 10^{-10} \mathrm{~cm}^{2} / \mathrm{s}$. The data indicated that carbonation in all cases enhanced Tc diffusivity in concrete cores. Significant increases in Tc diffusivities were noted when cores with higher concentrations of $\mathrm{Fe}(8 \%$ and $12 \%)$ were carbonated. These data indicate that carbonation of $\mathrm{Fe}$ containing concrete cores may enhance micro-cracking of concrete resulting in an increase in Tc diffusivity. Similar phenomena have been noted in previous studies in which Fe containing carbonated concrete cores was in contact with Tc-spiked soil cores with $4 \%$ moisture content. Also, the beneficial effect of Fe on reducing Tc diffusivity in non-carbonated specimens is not observable until the Fe content is at least $8 \%$ by mass. 
Table 10.3. Diffusivity data for Re-I in fractured concrete half cells

\begin{tabular}{lccccc}
\hline \multicolumn{1}{c}{ Core ID } & $\begin{array}{c}\text { Moisture } \\
\text { Content } \\
\text { wt } \%\end{array}$ & Carbonation & $\begin{array}{c}\text { Fe }(w t \\
\%)\end{array}$ & $\begin{array}{c}\text { Re } \\
\text { Diffusivity } \\
\left(\mathrm{cm}^{2} / \mathrm{s}\right)\end{array}$ & $\begin{array}{c}\text { I } \\
\text { Diffusivity } \\
\left(\mathrm{cm}^{2} / \mathrm{s}\right)\end{array}$ \\
\hline C-5-0-2 & 4 & $\mathrm{~N}$ & 0 & $1.36 \mathrm{E}-10$ & $3.13 \mathrm{E}-10$ \\
$\mathrm{C}-5-4-26$ & 4 & $\mathrm{~N}$ & 4 & $1.68 \mathrm{E}-10$ & $2.39 \mathrm{E}-10$ \\
$\mathrm{C}-5-0-1$ & 4 & $\mathrm{Y}$ & 0 & $1.18 \mathrm{E}-10$ & $5.90 \mathrm{E}-10$ \\
$\mathrm{C}-5-4-21$ & 4 & $\mathrm{Y}$ & 4 & $3.34 \mathrm{E}-10$ & $4.35 \mathrm{E}-10$ \\
$\mathrm{C}-5-0-7$ & 7 & $\mathrm{~N}$ & 0 & $3.75 \mathrm{E}-12$ & $1.25 \mathrm{E}-10$ \\
$\mathrm{C}-5-4-27$ & 7 & $\mathrm{~N}$ & 4 & $8.88 \mathrm{E}-11$ & $1.93 \mathrm{E}-10$ \\
$\mathrm{C}-5-0-5$ & 7 & $\mathrm{Y}$ & 0 & $2.60 \mathrm{E}-10$ & $2.77 \mathrm{E}-10$ \\
$\mathrm{C}-5-4-23$ & 7 & $\mathrm{Y}$ & 4 & $1.69 \mathrm{E}-10$ & $4.00 \mathrm{E}-10$ \\
$\mathrm{C}-5-0-10$ & 15 & $\mathrm{~N}$ & 0 & $2.03 \mathrm{E}-09$ & $2.33 \mathrm{E}-09$ \\
$\mathrm{C}-5-4-30$ & 15 & $\mathrm{~N}$ & 4 & $4.02 \mathrm{E}-10$ & $1.76 \mathrm{E}-09$ \\
$\mathrm{C}-5-0-6$ & 15 & $\mathrm{Y}$ & 0 & $6.90 \mathrm{E}-10$ & $5.10 \mathrm{E}-10$ \\
$\mathrm{C}-5-4-24$ & 15 & $\mathrm{Y}$ & 4 & $6.72 \mathrm{E}-10$ & $1.21 \mathrm{E}-09$ \\
\hline
\end{tabular}



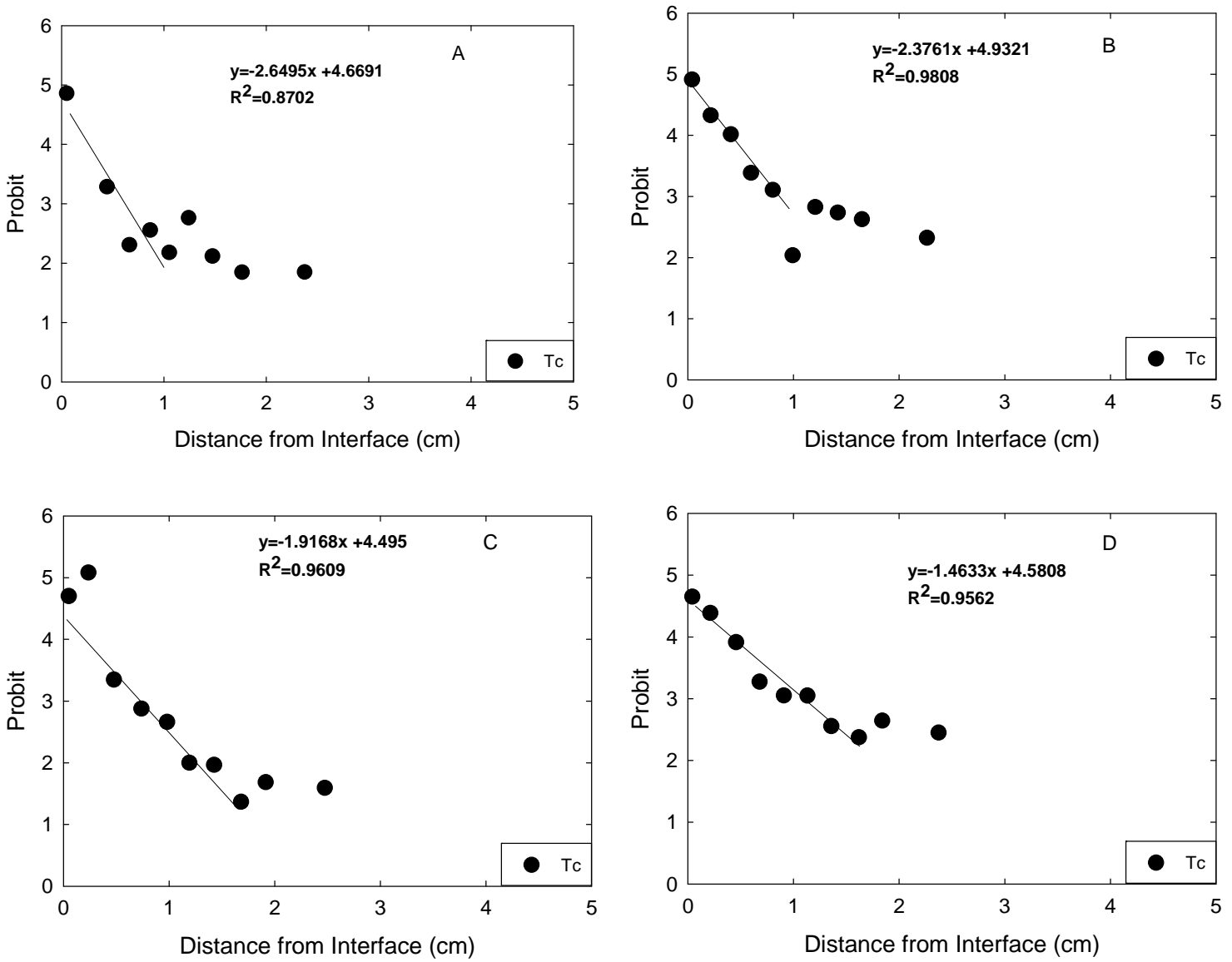

Figure 10.4. Probit analysis of Tc cores. Top left: $4 \%$ moisture content, no Fe, no carbonation; Top right: 4\% moisture content, no Fe, carbonated; Bottom left: 4\% moisture content, $4 \% \mathrm{Fe}$, no carbonation; Bottom right: $4 \%$ moisture content, $4 \%$ Fe, carbonated. 

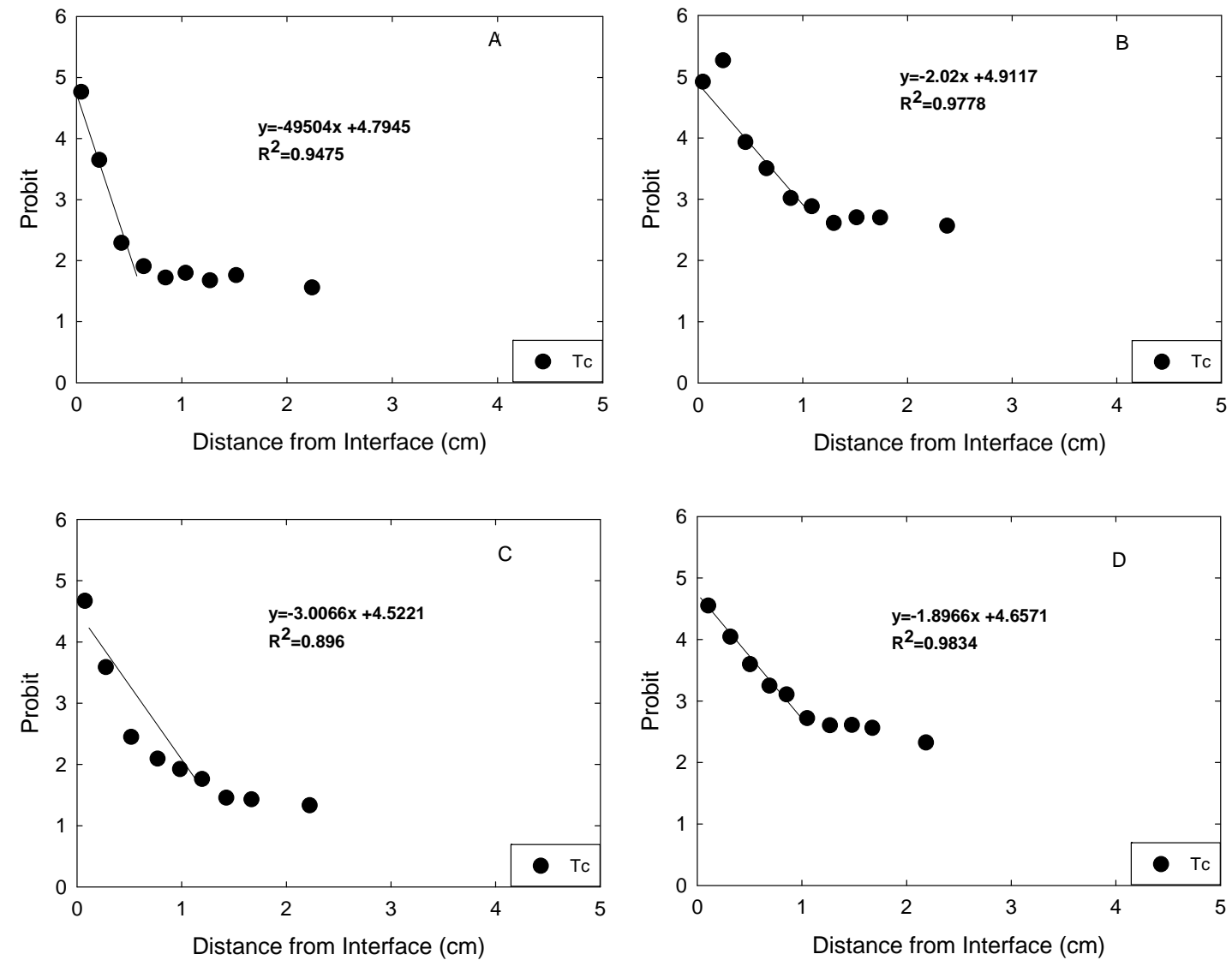

Figure 10.5. Probit analysis of Tc cores. Top left: $4 \%$ moisture content, $8 \% \mathrm{Fe}$, no carbonation; Top right: $4 \%$ moisture content, $8 \% \mathrm{Fe}$, carbonated; Bottom left: $4 \%$ moisture content, $12 \% \mathrm{Fe}$, no carbonation; Bottom right: $4 \%$ moisture content, $12 \% \mathrm{Fe}$, carbonated.

Table 10.4. Diffusivity of Tc in fractured concrete cores

\begin{tabular}{cccc}
\hline Core ID & Carbonation & $\begin{array}{c}\text { Fe } \\
(\mathrm{wt} \%)\end{array}$ & $\begin{array}{c}\text { Tc Diffusivity } \\
\left(\mathrm{cm}^{2} / \mathrm{s}\right)\end{array}$ \\
\hline Tc-C-10-5-0-101 & $\mathrm{N}$ & 0 & $1.1 \times 10^{-10}$ \\
Tc-C-10-5-0-102 & $\mathrm{Y}$ & 0 & $1.4 \times 10^{-10}$ \\
Tc-C-10-5-4-105 & $\mathrm{N}$ & 4 & $2.1 \times 10^{-10}$ \\
Tc-C-10-5-4-106 & $\mathrm{Y}$ & 4 & $3.6 \times 10^{-10}$ \\
Tc-C-10-5-8-107 & $\mathrm{N}$ & 8 & $3.1 \times 10^{-11}$ \\
Tc-C-10-5-8-108 & $\mathrm{Y}$ & 8 & $1.9 \times 10^{-10}$ \\
Tc-C-10-5-12-110 & $\mathrm{N}$ & 12 & $8.4 \times 10^{-11}$ \\
Tc-C-10-5-12-111 & $\mathrm{Y}$ & 12 & $2.1 \times 10^{-10}$ \\
\hline
\end{tabular}


In summary, these data showed the following:

- The calculated diffusivities for Re ranged from $3.8 \times 10^{-12}$ to $2 \times 10^{-9} \mathrm{~cm}^{2} / \mathrm{s}$ and for I ranged from $1.3 \times 10^{-10}$ to $2.3 \times 10^{-9} \mathrm{~cm}^{2} / \mathrm{s}$ in fractured concrete. The highest Re and I diffusivities were observed in fractured concrete cores that were in contact with spiked soils with $15 \%$ moisture content.

- Additions of $4 \%$ by weight Fe did not noticeably affect the diffusivities of Re and I in fractured concrete.

- The diffusivity of Tc in fractured concrete cores ranged from $3.1 \times 10^{-11} \mathrm{~cm}^{2} / \mathrm{s}$ to $3.6 \times 10^{-10} \mathrm{~cm}^{2} / \mathrm{s}$. Carbonation in all cases increased the Tc diffusion coefficient. The beneficial effect of Fe on reducing Tc diffusivity in non-carbonated specimens was not observable until the Fe content was at least 8\% by mass. 


\subsection{Diffusion of lodine, Rhenium, and Tc from Fractured Concrete into Soil}

Two sets of diffusion experiments were initiated using fractured concrete-soil half cells. The objective was to examine the diffusion from spiked and fractured concrete cores into soil half cells. In one set, Re and I spiked concrete specimens were prepared with and without carbonation and additions of 0,4 , 8 , and $12 \%$ Fe. After curing, these concrete specimens were fractured and half cells were prepared by placing these specimens in contact with soil at 4,7 , and $15 \%$ initial moisture content. A similar set of concrete specimens was prepared that contained Tc spikes, with and without carbonation, and $0,4,8$, and $12 \% \mathrm{Fe}$. After curing, these Tc-spiked specimens were fractured and placed in contact with soil at $4 \%$ initial moisture content in a half cell configuration. The characteristics of the specimens used are listed in Table 11.1.

Table 11.1. Characteristics of concrete specimens used in concrete-soil half cells

\begin{tabular}{|c|c|c|c|c|c|c|c|c|}
\hline Core ID & $\begin{array}{l}\text { Length } \\
(\mathrm{cm})\end{array}$ & $\begin{array}{l}\text { Diameter } \\
(\mathrm{cm})\end{array}$ & $\begin{array}{c}\text { Volume } \\
\left(\mathrm{cm}^{3}\right)\end{array}$ & $\begin{array}{c}\text { Weight } \\
\text { (g) }\end{array}$ & $\begin{array}{l}\text { Density } \\
\left(\mathrm{g} / \mathrm{cm}^{3}\right)\end{array}$ & $\begin{array}{l}\text { Colloidal } \\
\text { Iron }(\%)\end{array}$ & Carbonation & $\begin{array}{c}\text { Initial } \\
\text { Moisture } \\
\text { Content }^{(a)}(\%)\end{array}$ \\
\hline \multicolumn{9}{|c|}{ Cores containing Re and I } \\
\hline C-08-5-0-501 & 3.92 & 4.32 & 57.31 & 137.08 & 2.39 & 0 & $\mathrm{~N}$ & 4 \\
\hline C- $-08-5-0-502$ & 3.94 & 4.31 & 57.43 & 137.23 & 2.39 & 0 & $\mathrm{~N}$ & 7 \\
\hline$C-08-5-0-503$ & 4.13 & 4.32 & 60.52 & 145.80 & 2.41 & 0 & $\mathrm{~N}$ & 15 \\
\hline C-08-5-0-504 & 4.00 & 4.32 & 58.45 & 141.89 & 2.43 & 0 & $\mathrm{Y}$ & 4 \\
\hline C-08-5-0-505 & 3.86 & 4.32 & 56.55 & 138.20 & 2.44 & 0 & $\mathrm{Y}$ & 7 \\
\hline C-08-5-0-507 & 3.99 & 4.31 & 58.29 & 141.02 & 2.42 & 0 & $\mathrm{Y}$ & 15 \\
\hline C-08-5-4-526 & 3.86 & 4.32 & 56.65 & 136.50 & 2.41 & 4 & $\mathrm{~N}$ & 4 \\
\hline$C-08-5-4-527$ & 4.14 & 4.32 & 60.61 & 145.87 & 2.41 & 4 & $\mathrm{~N}$ & 7 \\
\hline C- $08-5-4-528$ & 3.80 & 4.32 & 55.83 & 134.05 & 2.40 & 4 & $\mathrm{~N}$ & 15 \\
\hline$C-08-5-4-530$ & 3.96 & 4.33 & 58.26 & 139.27 & 2.39 & 4 & $\mathrm{Y}$ & 4 \\
\hline C-08-5-4-531 & 4.11 & 4.32 & 60.31 & 145.56 & 2.41 & 4 & $\mathrm{Y}$ & 7 \\
\hline C-08-5-4-532 & 3.85 & 4.32 & 56.31 & 134.81 & 2.39 & 4 & $\mathrm{Y}$ & 15 \\
\hline$C-08-5-8-552$ & 4.12 & 4.31 & 60.08 & 146.32 & 2.44 & 8 & $\mathrm{~N}$ & 4 \\
\hline C- $08-5-8-553$ & 4.04 & 4.32 & 59.36 & 145.89 & 2.46 & 8 & $\mathrm{~N}$ & 7 \\
\hline C- $08-5-8-554$ & 3.89 & 4.30 & 56.53 & 138.57 & 2.45 & 8 & $\mathrm{~N}$ & 15 \\
\hline C- $08-5-8-555$ & 3.95 & 4.30 & 57.36 & 140.05 & 2.44 & 8 & $\mathrm{Y}$ & 4 \\
\hline$C-08-5-8-556$ & 3.92 & 4.30 & 57.05 & 140.48 & 2.46 & 8 & $\mathrm{Y}$ & 7 \\
\hline C-08-5-8-557 & 4.07 & 4.30 & 59.13 & 145.19 & 2.46 & 8 & $\mathrm{Y}$ & 15 \\
\hline C-08-5-12-576 & 4.05 & 4.31 & 59.10 & 144.99 & 2.45 & 12 & $\mathrm{~N}$ & 4 \\
\hline C-08-5-12-577 & 4.08 & 4.31 & 59.46 & 144.82 & 2.44 & 12 & $\mathrm{~N}$ & 7 \\
\hline C-08-5-12-578 & 3.84 & 4.31 & 55.96 & 137.24 & 2.45 & 12 & $\mathrm{~N}$ & 15 \\
\hline C-08-5-12-580 & 4.06 & 4.31 & 59.36 & 144.46 & 2.43 & 12 & $\mathrm{Y}$ & 4 \\
\hline C-08-5-12-581 & 4.29 & 4.31 & 62.49 & 153.33 & 2.45 & 12 & $\mathrm{Y}$ & 7 \\
\hline C-08-5-12-552 & 3.92 & 4.31 & 57.04 & 141.77 & 2.49 & 12 & $\mathrm{Y}$ & 15 \\
\hline \multicolumn{9}{|c|}{ Cores Containing Tc } \\
\hline C-10-5-0-202 & 4.29 & 4.32 & 62.87 & 140.34 & 2.23 & 0 & $\mathrm{~N}$ & 4 \\
\hline C-10-5-0-203 & 4.51 & 4.34 & 66.73 & 149.74 & 2.24 & 0 & $\mathrm{Y}$ & 4 \\
\hline C-10-5-4-204 & 4.42 & 4.32 & 64.68 & 146.88 & 2.27 & 4 & $\mathrm{~N}$ & 4 \\
\hline C-10-5-4-205 & 4.67 & 4.32 & 68.39 & 155.53 & 2.27 & 4 & $\mathrm{Y}$ & 4 \\
\hline$C-10-5-8-207$ & 4.56 & 4.32 & 66.82 & 153.63 & 2.3 & 8 & $\mathrm{~N}$ & 4 \\
\hline C-10-5-8-208 & 4.53 & 4.32 & 66.46 & 152.56 & 2.3 & 8 & $\mathrm{Y}$ & 4 \\
\hline C-10-5-12-210 & 4.63 & 4.32 & 67.94 & 157.43 & 2.32 & 12 & $\mathrm{~N}$ & 4 \\
\hline C-10-5-12-211 & 4.61 & 4.32 & 67.95 & 157.06 & 2.32 & 12 & $\mathrm{Y}$ & 4 \\
\hline
\end{tabular}



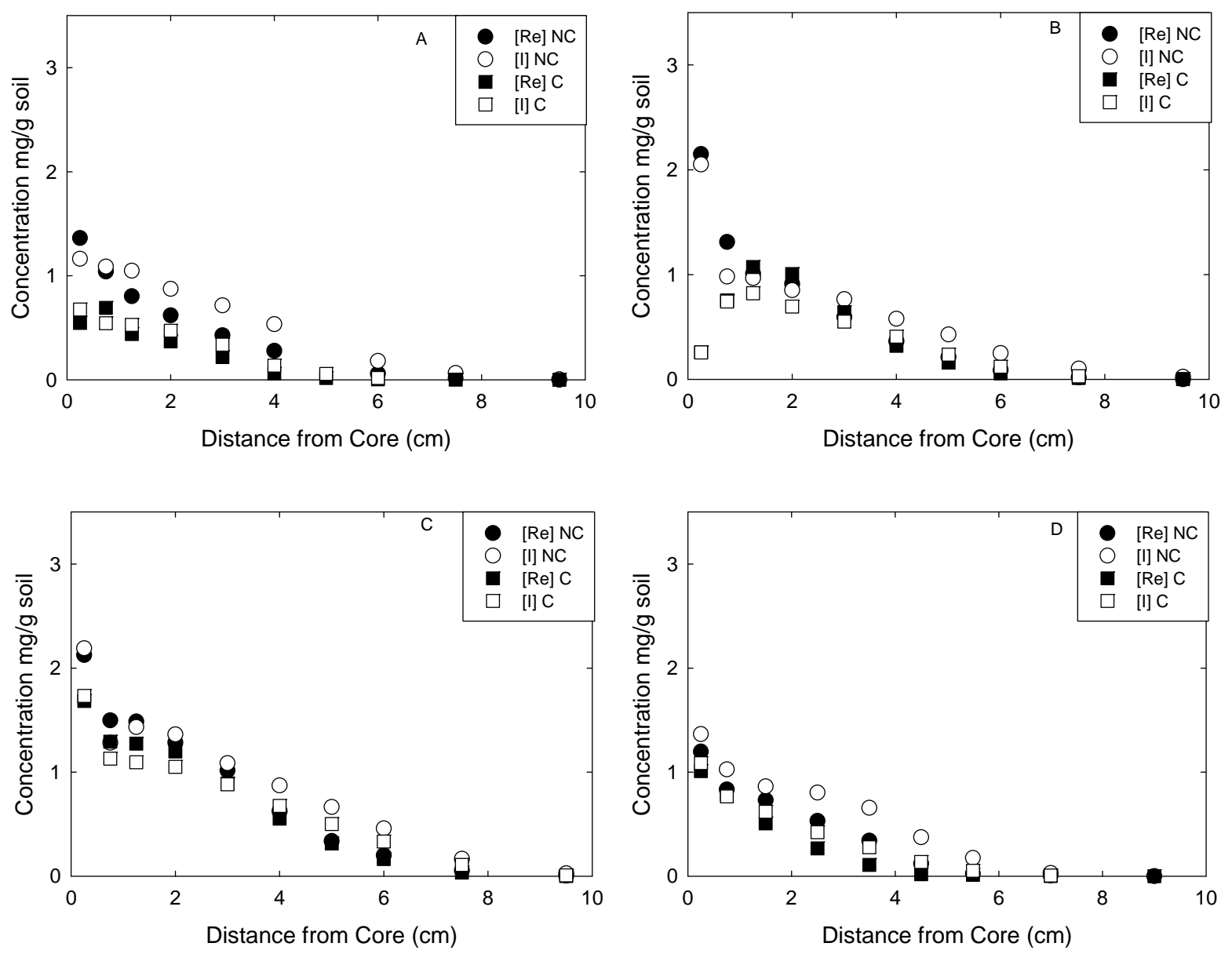

Figure 11.1. Concentration profiles for soil half-cell I and Re profiles. Top left: $4 \%$ moisture with $0 \%$ Fe; Top right: $4 \%$ moisture with $4 \%$ Fe; Bottom left: $4 \%$ moisture with $8 \%$ Fe; Bottom right: $4 \%$ moisture with $12 \% \mathrm{Fe}$.

The diffusion profiles of soil half cells are shown in Figures 11.1 through 11.3, and the Re and I spiked concrete half cells are shown in Figures 11.4 through 11.6. Low moisture (4\%) soil cores showed well defined diffusion gradients; however, the diffusivity of both Re and I was low due to lack of adequate moisture (Figure 11.1). The low moisture (4\%) soils in contact with spiked carbonated concrete without $\mathrm{Fe}$ showed lower diffusivity as compared to soils in contact with uncarbonated, Fe-free concrete. Metallic Fe additions to the concrete also appeared to depress Re and I diffusivities into soils with 4\% moisture (Figure 11.1).

Rhenium and I showed deeper penetration (increased diffusivity) into soils with 7\% moisture content (Figure 11.2). Carbonation of concrete without iron also seemed to decrease Re and I diffusivities in soils contacting these half cells. The addition of metallic Fe to spiked concrete also noticeably depressed Re and I diffusivities in soils.

In soils with the highest moisture content (15\%), the diffusion progressed to the extent that there were no observable diffusion gradients (Figure 11.3). When the experiments were terminated, apparent diffusion equilibrium had been reached, as indicated by relatively constant ionic concentrations 
throughout the soil half cells. However, the influence of carbonation was very pronounced in that the concentrations of Re and I were significantly higher in soils in contact with uncarbonated concrete with or without Fe additions. Lack of distinct concentration gradients precluded computation of diffusion coefficients in these high moisture content (15\%) soils.

The diffusion profiles of Re and I in spiked concrete half cells are shown in Figures 11.4 through 11.6. One distinctive feature of these profiles is the apparent bidirectional nature of ion diffusion in the concrete cores. The reason for such anomaly was apparent at the end of the experiment when the half cells were dismantled for sampling. During vertical storage of these half cells, some of the soils from the soil half cells at the top had worked down the gap between the concrete half cells and the surrounding plastic tube. Therefore, the soils contacting both top and bottom of the concrete half cells inadvertently seemed to have set up bidirectional diffusion in Re and I spiked half cells.

The soil half-cell diffusion profiles of concrete cores spiked with Tc are shown in Figure 11.7. The data indicated that Tc had only penetrated into the soil to a depth of $<2 \mathrm{~cm}$. Because of an insufficient number of data points in the diffusion profile, probit analysis was not conducted.
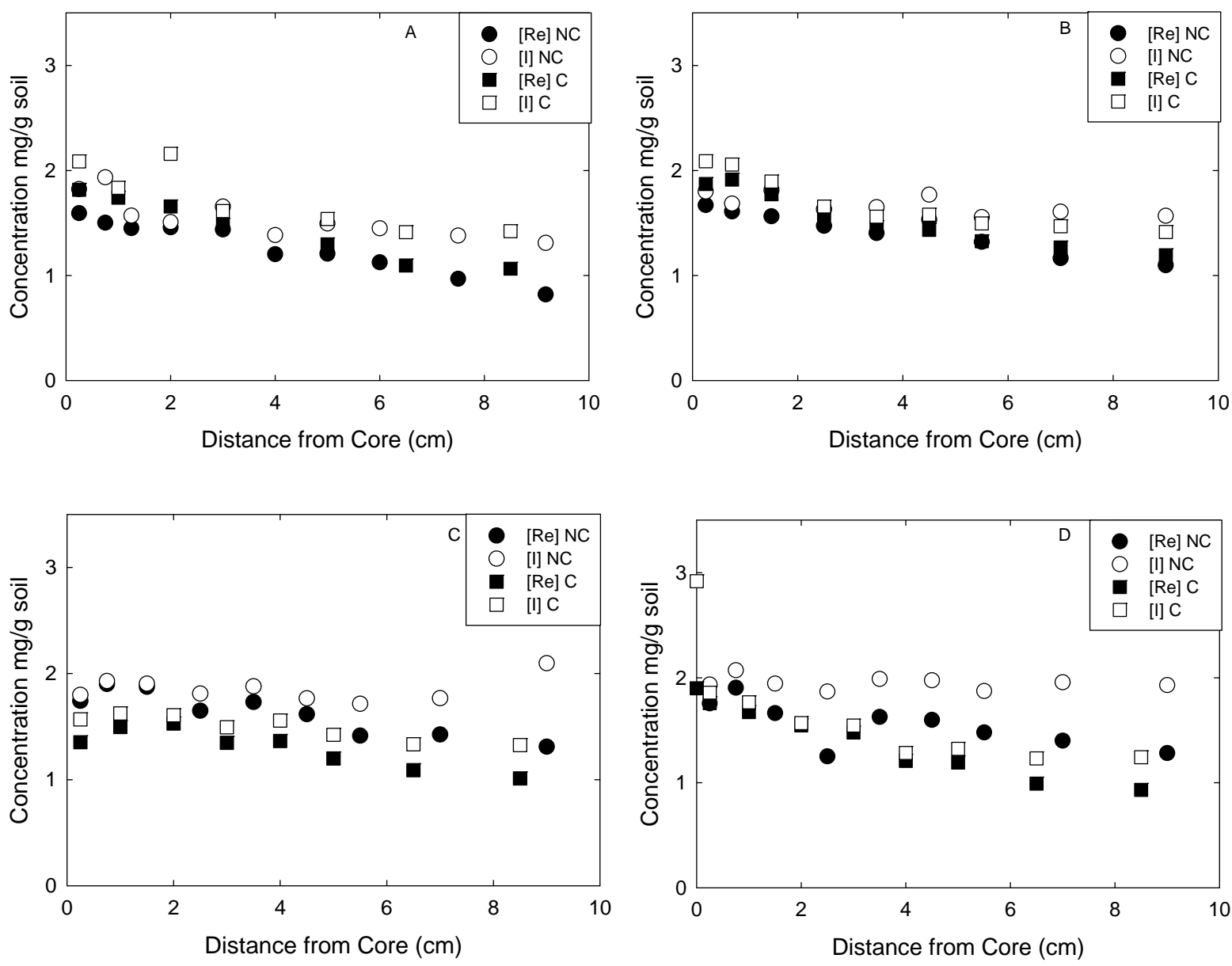

Figure 11.2. Concentration profiles for soil half-cell I and Re profiles: a) $7 \%$ moisture with $0 \% \mathrm{Fe}$; b) $7 \%$ moisture with $4 \% \mathrm{Fe}$; c) $7 \%$ moisture with $8 \% \mathrm{Fe}$; d) $7 \%$ moisture with $12 \% \mathrm{Fe}$ 

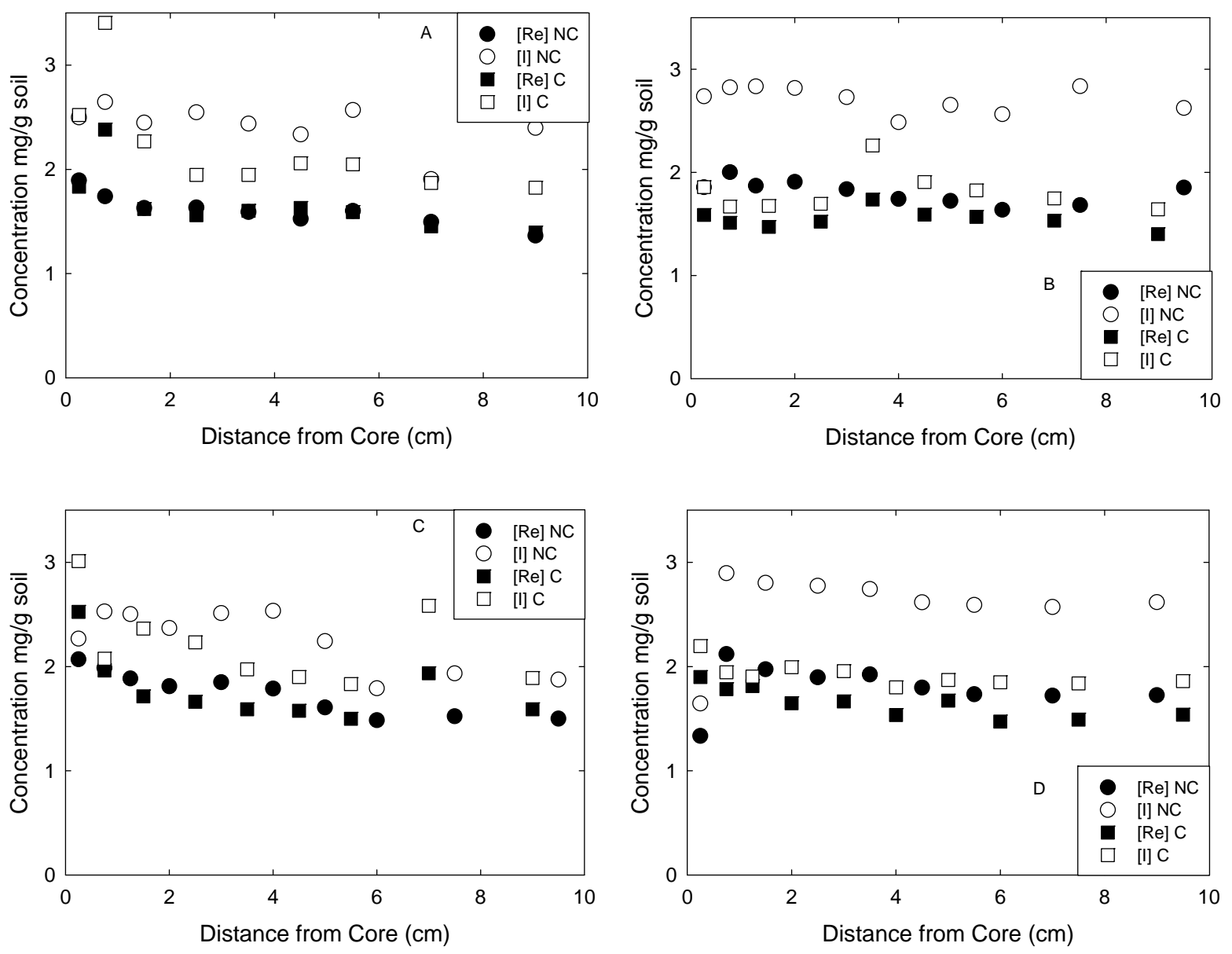

Figure 11.3. Profiles for soil half-cell I and Re profiles. Top left: $15 \%$ moisture with $0 \% \mathrm{Fe}$; Top right: $15 \%$ moisture with $4 \%$ Fe; Bottom left: $15 \%$ moisture with $8 \%$ Fe; Bottom right: $15 \%$ moisture with $12 \% \mathrm{Fe}$. 

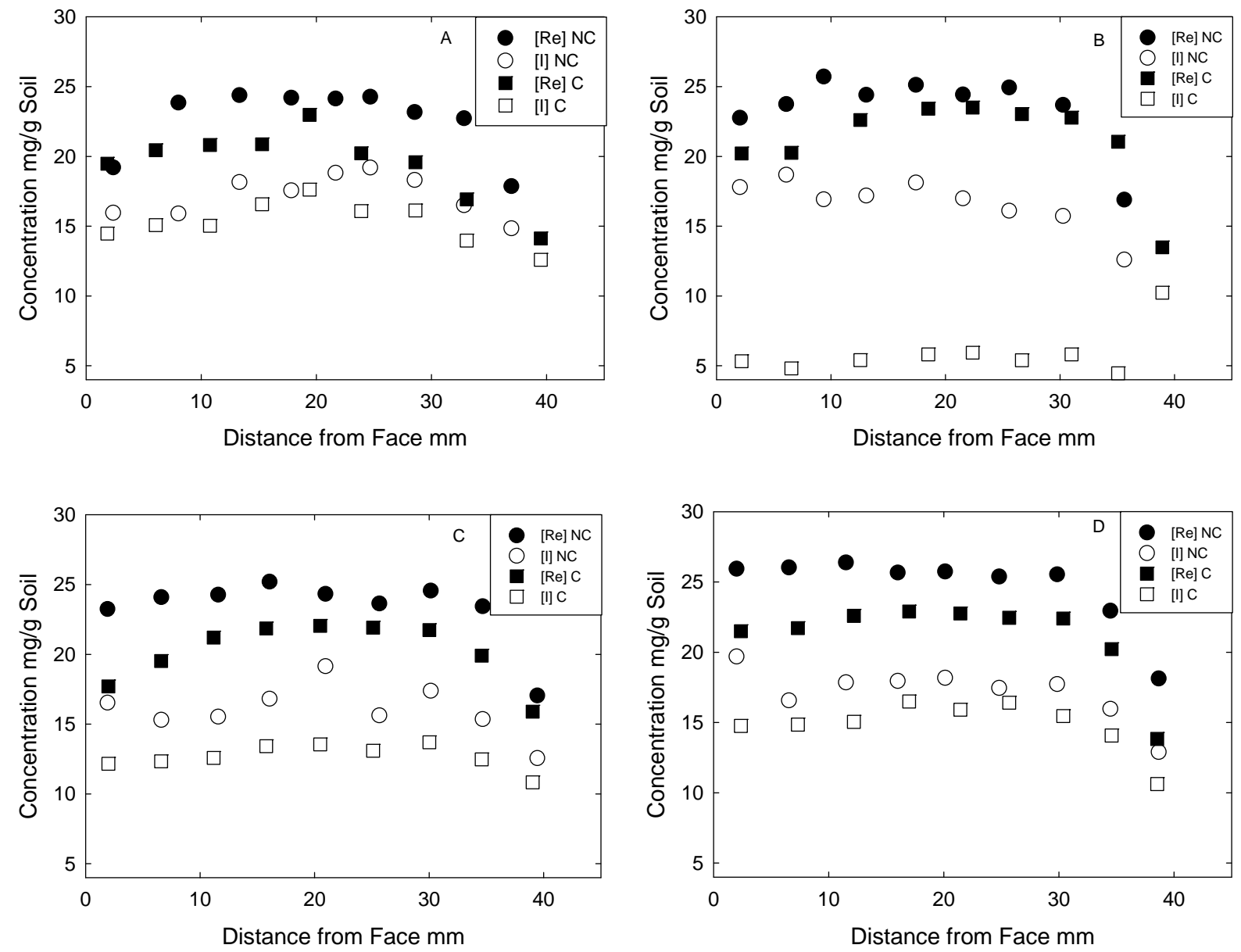

Figure 11.4. I and Re concrete half-cell concentration profile. Top left: $4 \%$ soil moisture and $0 \% \mathrm{Fe}$; Top right: $4 \%$ soil moisture and $4 \% \mathrm{Fe}$; Bottom left: $4 \%$ soil moisture and $8 \% \mathrm{Fe}$; Bottom right: $4 \%$ moisture and $12 \% \mathrm{Fe}$. 

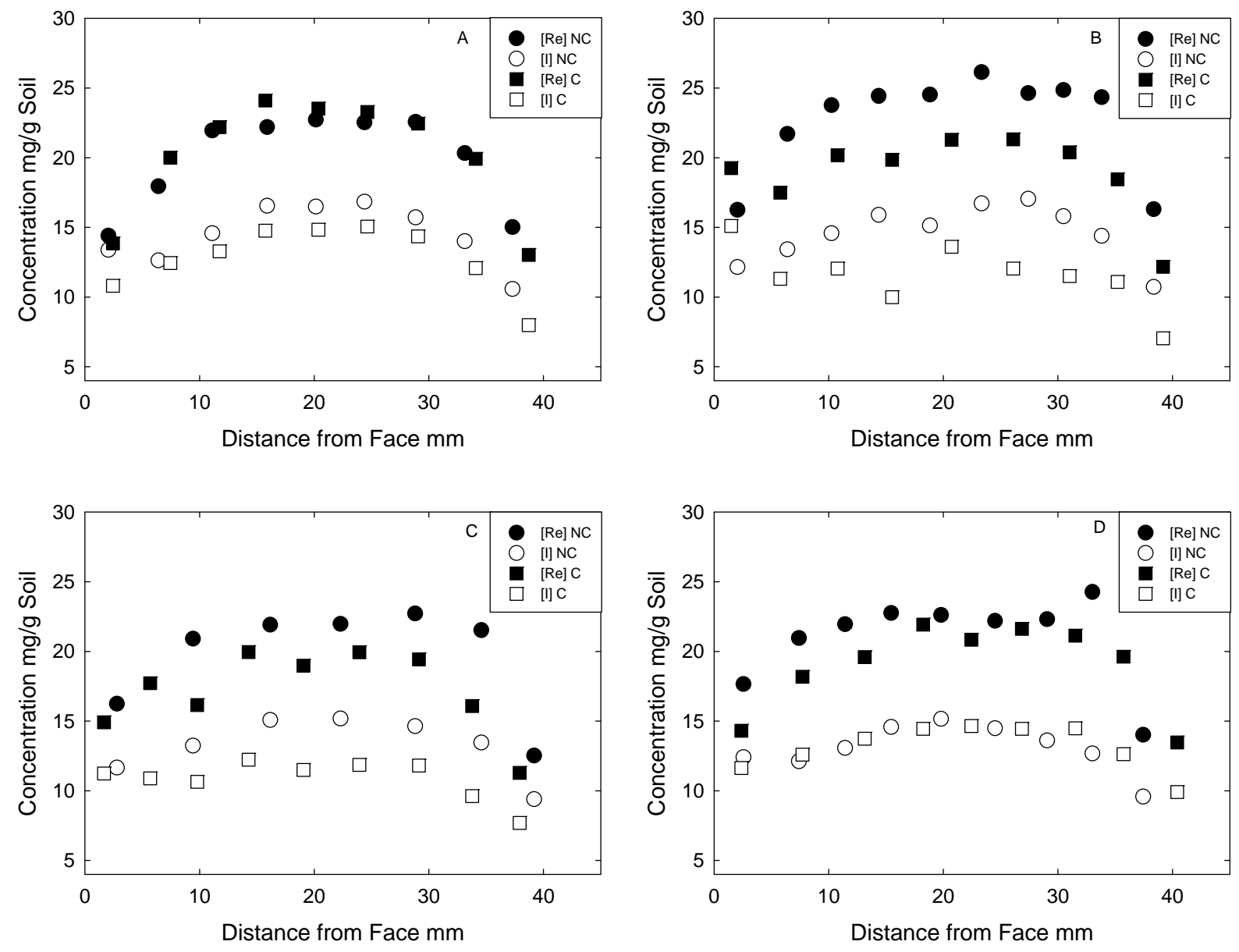

Figure 11.5. I and Re concrete half-cell concentration profile. Top left: $7 \%$ soil moisture and $0 \% \mathrm{Fe}$; Top right: $7 \%$ soil moisture and 4\% Fe; Bottom left: $7 \%$ soil moisture and $8 \% \mathrm{Fe}$; Bottom right: $7 \%$ moisture and $12 \%$ Fe. 

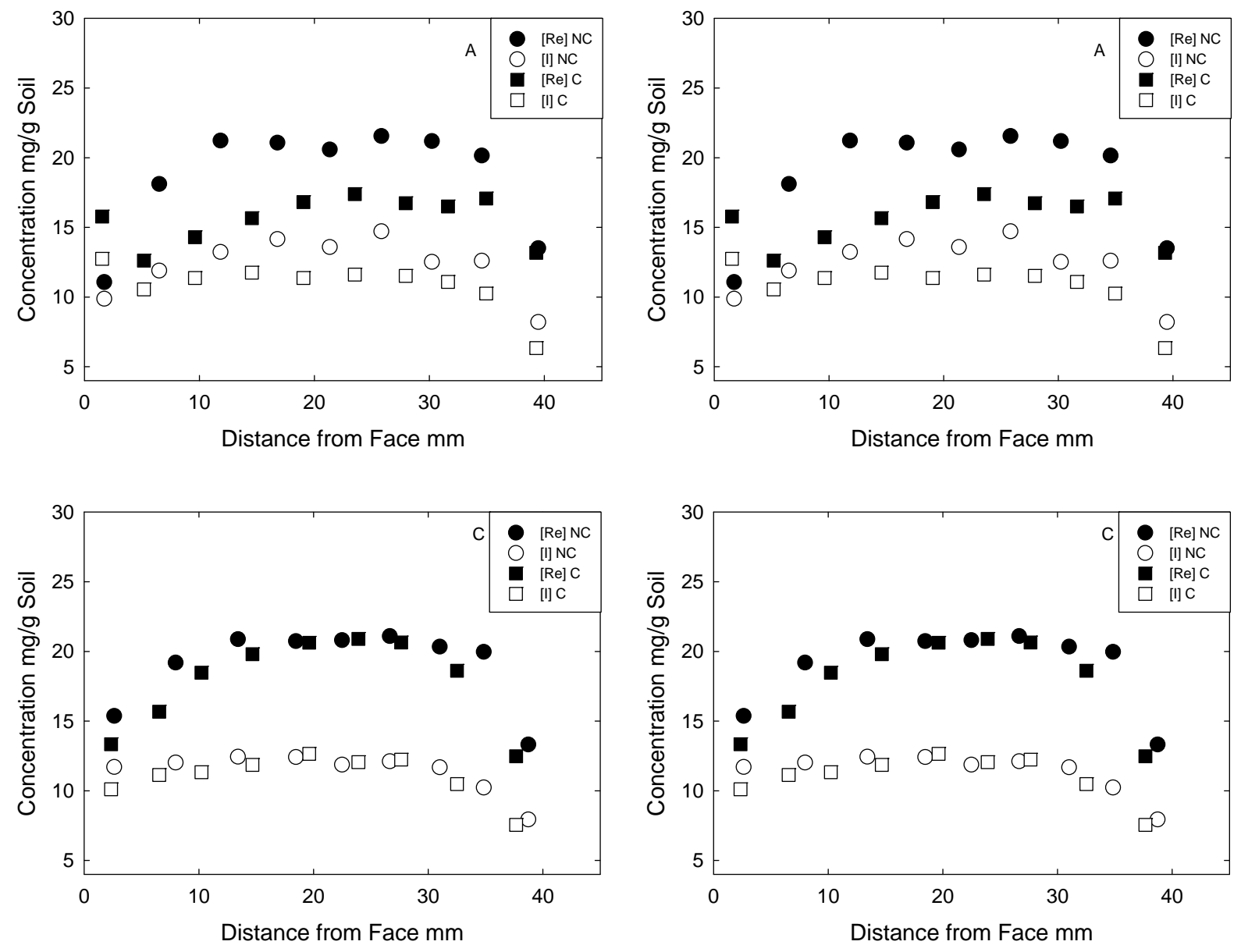

Figure 11.6. I and Re concrete half-cell concentration profile. Top left: $15 \%$ soil moisture and $0 \% \mathrm{Fe}$; Top right: $15 \%$ soil moisture and $4 \% \mathrm{Fe}$; Bottom left: $15 \%$ soil moisture and $8 \% \mathrm{Fe}$; Bottom right: $15 \%$ moisture and $12 \% \mathrm{Fe}$. 

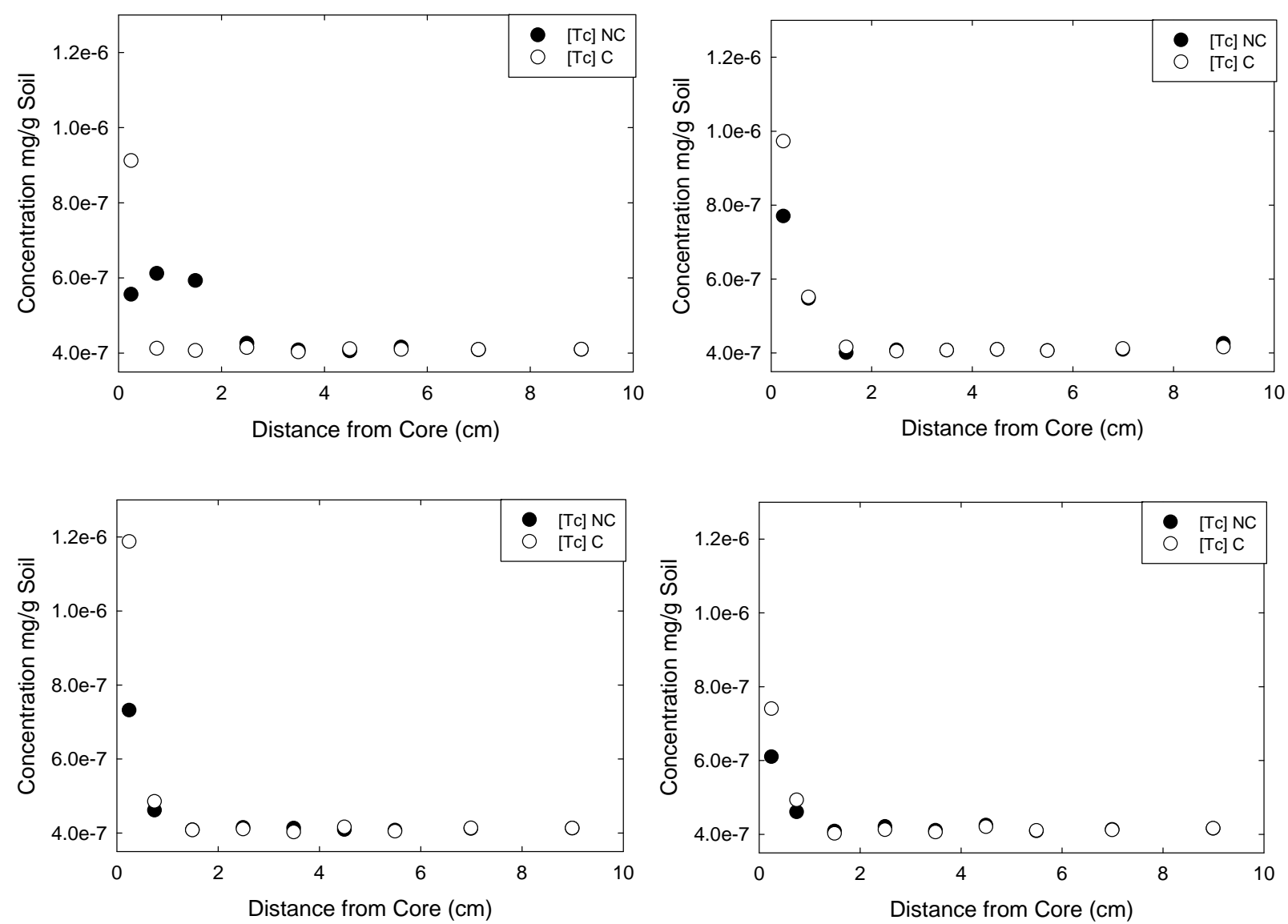

Figure 11.7. Concentration profiles of $\mathrm{Tc}$ in soil cores in contact with spiked, carbonated, and noncarbonated fractured concrete cores. Top left: $4 \%$ soil moisture, $0 \% \mathrm{Fe}$; Top right: $4 \%$ soil moisture, $4 \% \mathrm{Fe}$; Bottom left: 4\% soil moisture, $8 \% \mathrm{Fe}$; Bottom right: $4 \%$ soil moisture, $12 \% \mathrm{Fe}$.

\subsection{Probit Analysis}

The probit plots for the diffusion data are presented in Figures 11.8-11.10. The diffusion coefficients are tabulated in Table 11.2. 

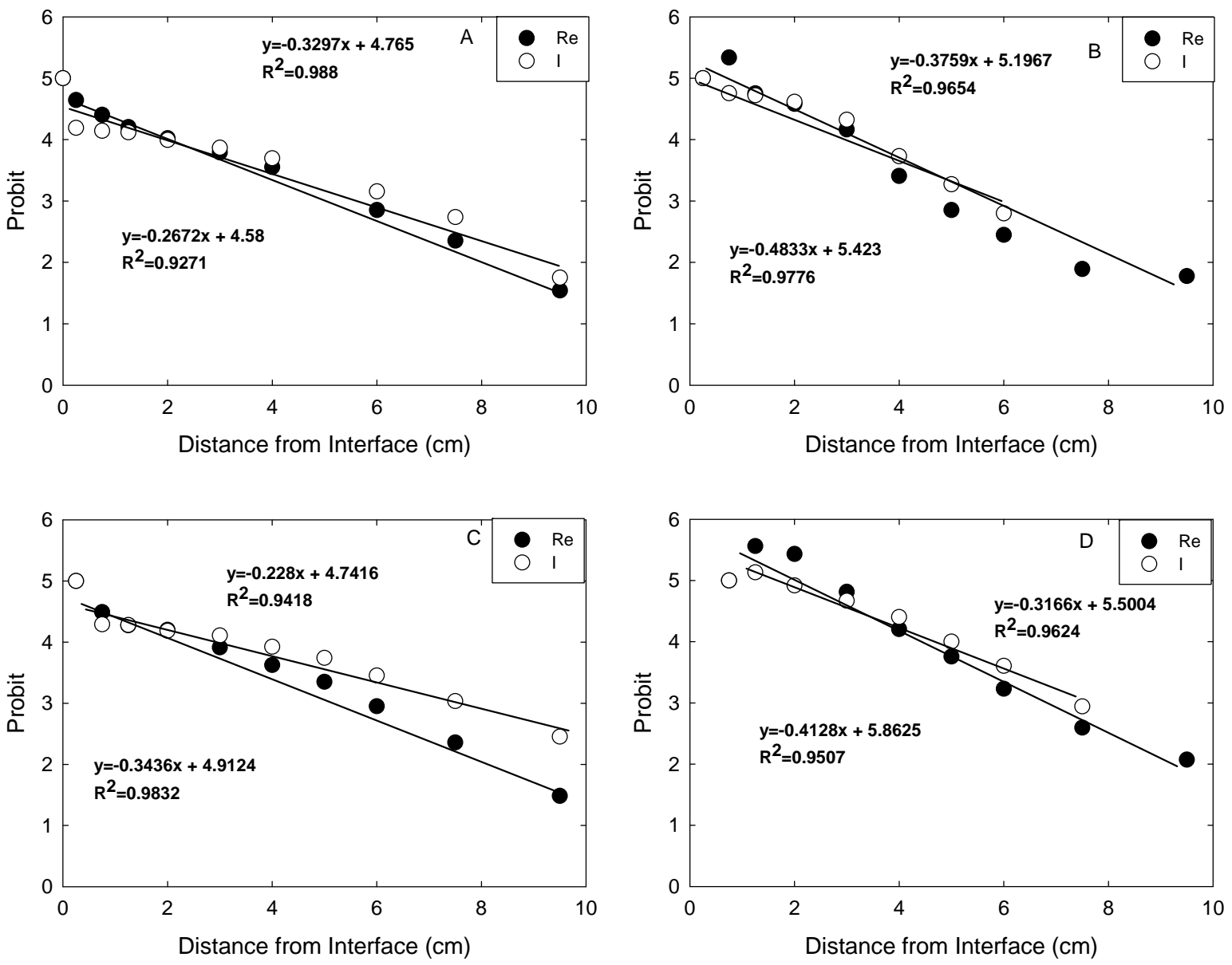

Figure 11.8. Probit analysis for Re and I Cores. Top left: 4\% moisture content, no Fe, no carbonation; Top right: 4\% moisture content, no Fe, carbonated; Bottom left: 4\% moisture content, 4\% Fe, no carbonation; Bottom right: 4\% moisture content, $4 \% \mathrm{Fe}$, carbonated. 

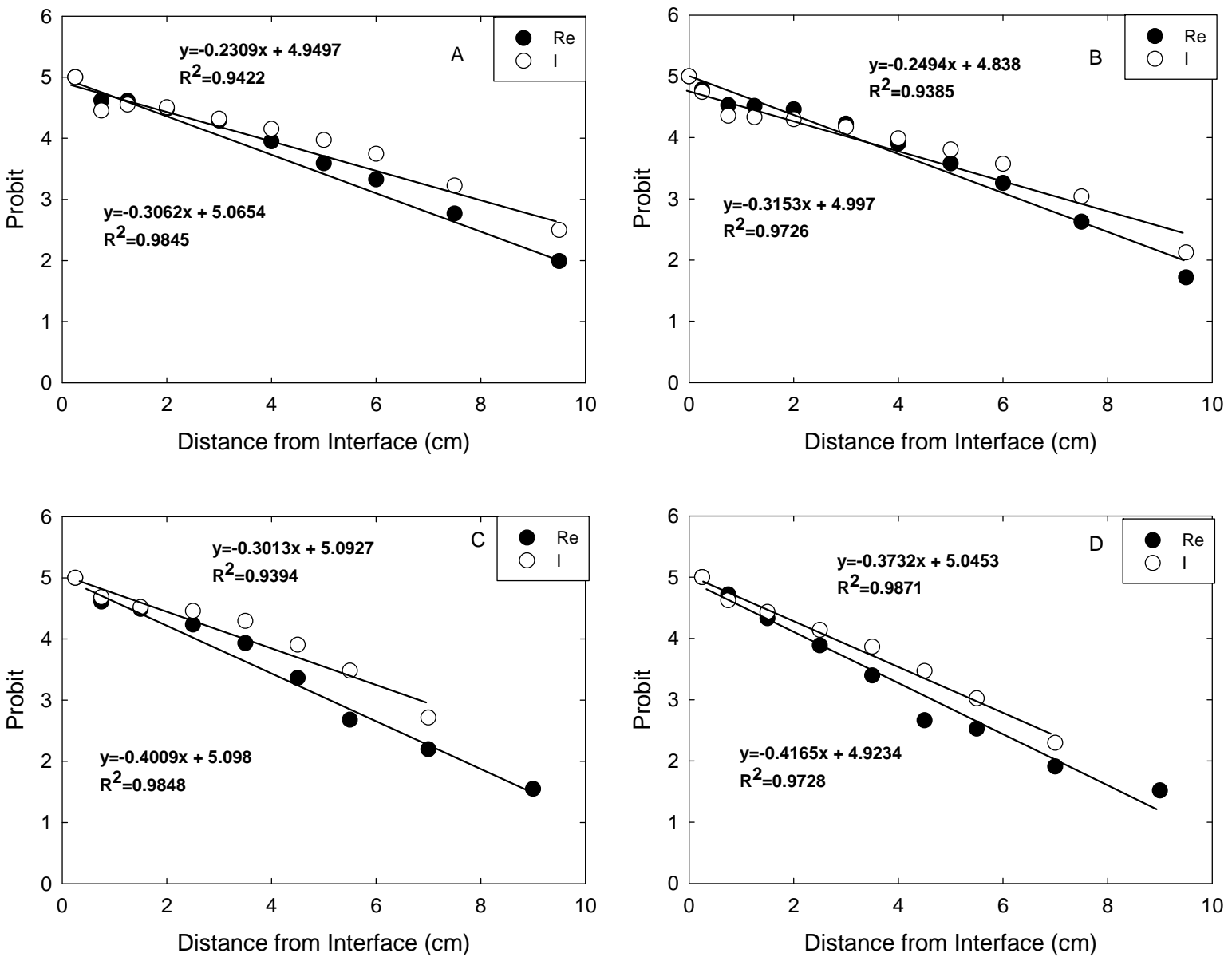

Figure 11.9. Probit analysis for Re and I Cores. Top left: $4 \%$ moisture content, $8 \% \mathrm{Fe}$, no carbonation; Top right: $4 \%$ moisture content, $8 \% \mathrm{Fe}$, carbonated; Bottom left: $4 \%$ moisture content, $12 \%$ $\mathrm{Fe}$, no carbonation; Bottom right: $4 \%$ moisture content, $12 \% \mathrm{Fe}$, carbonated. 

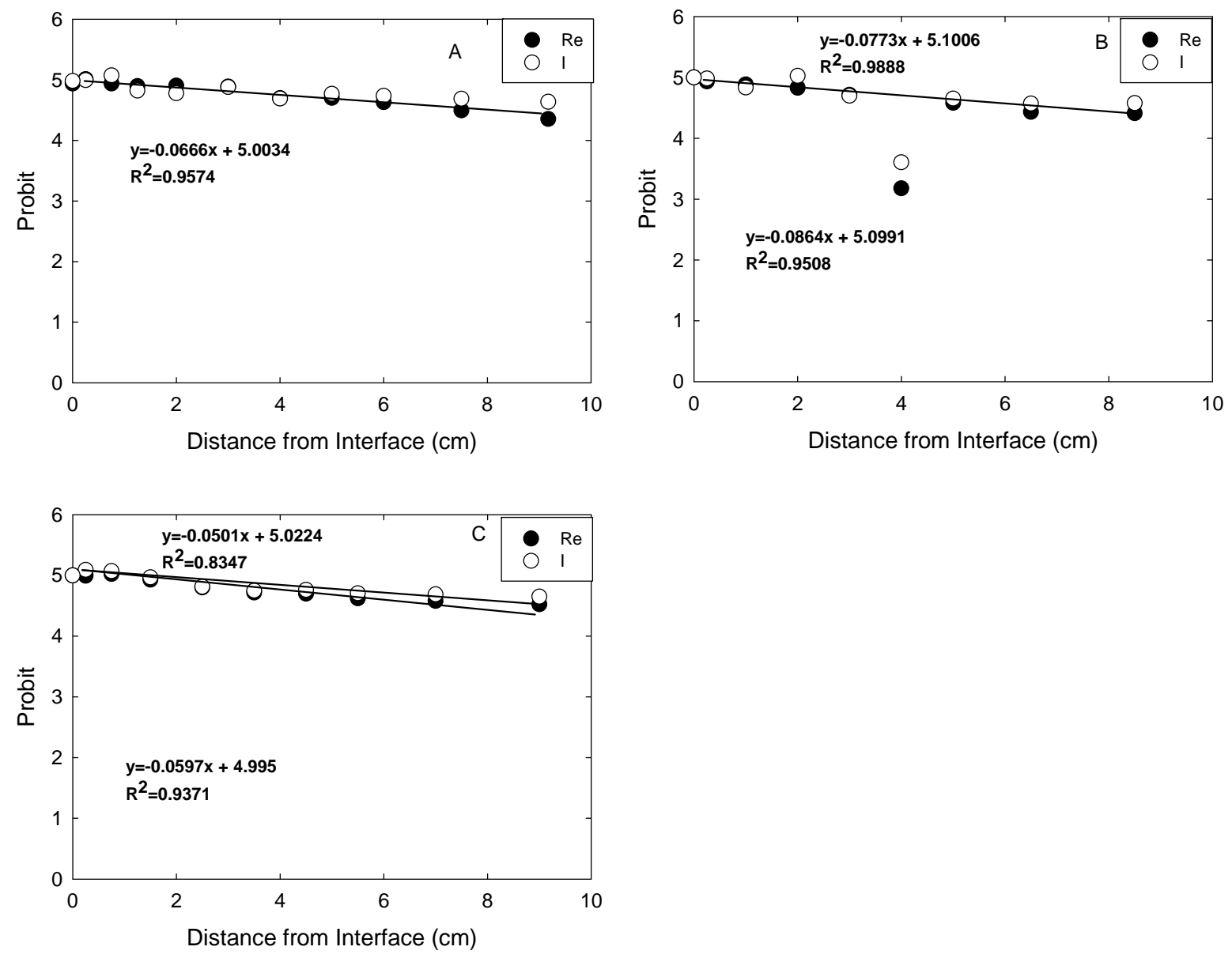

Figure 11.10. Probit analysis for Re and I Cores. Top left: 7\% moisture content, no Fe, no carbonation; Top right: 7\% moisture content, no Fe, carbonated; Bottom left: 7\% moisture content, 4\% $\mathrm{Fe}$, carbonated.

The probit analytical plots for these sets of diffusion data are shown in Figures 11.8-11.10 and the resulting Re and I diffusion coefficient values are tabulated in Table 11.2. The calculations showed that at $4 \%$ moisture content, with no iron present, carbonation reduced the diffusivities of both Re and I in soils, roughly by half. The addition of $4 \%$ by mass Fe into un-carbonated concrete did not significantly affect Re and I diffusivities in soil. In carbonated specimens, adding 4\% Fe seemed to increase only I diffusivity without significantly affecting Re diffusivity. When the concentrations of Fe in concrete cores were increased to $8 \%$, significantly enhanced diffusivities in soils were observed. For instance, in soils in contact with un-carbonated concrete cores, the presence of $8 \% \mathrm{Fe}$ in the concrete increased $\mathrm{Re}$ and I diffusivities by $\sim 17$ and $36 \%$, respectively. With carbonation, however, the diffusivities of both $\mathrm{Re}$ and I more than doubled as compared to carbonated specimens with no Fe. Similarly, increasing the Fe content to $12 \%$ by mass in both un-carbonated and carbonated concrete increased Re diffusivities soils by about a third as compared to soils contacting cores with no added Fe. In soils contacting similarly treated concrete cores, the I diffusivities did not change significantly (carbonation) or decreased by $\sim 20 \%$ (no carbonation). 
In soil cores with higher moisture content (7\%) and in contact with carbonated concrete cores containing no iron, the diffusivity of Re was $\sim 20 \%$ lower than in soils in contact with un-carbonated concrete cores. The addition of $4 \% \mathrm{Fe}$ by mass to carbonated concrete cores increased

Table 11.2. Diffusivity analysis Re and I in soil half cells

\begin{tabular}{cccccc}
\hline Core ID & MC (Wt \%) & Carbonation & Fe (wt \%) & $\begin{array}{c}\text { Re } \\
\text { Diffusivity } \\
\left(\mathrm{cm}^{2} / \mathrm{s}\right)\end{array}$ & $\begin{array}{c}\text { I } \\
\text { Diffusivity } \\
\left(\mathrm{cm}^{2} / \mathrm{s}\right)\end{array}$ \\
\hline C-08-5-0-501 & 4 & $\mathrm{~N}$ & 0 & $2.2 \mathrm{E}-09$ & $3.3 \mathrm{E}-09$ \\
$\mathrm{C}-08-5-0-502$ & 7 & $\mathrm{~N}$ & 0 & $2.1 \mathrm{E}-07$ & NA \\
C-08-5-0-504 & 4 & $\mathrm{Y}$ & 0 & $1.0 \mathrm{E}-09$ & $1.7 \mathrm{E}-09$ \\
$\mathrm{C}-08-5-0-505$ & 7 & $\mathrm{Y}$ & 0 & $1.7 \mathrm{E}-07$ & $1.2 \mathrm{E}-07$ \\
$\mathrm{C}-08-5-4-526$ & 4 & $\mathrm{~N}$ & 4 & $2.0 \mathrm{E}-09$ & $4.5 \mathrm{E}-09$ \\
$\mathrm{C}-08-5-4-530$ & 4 & $\mathrm{Y}$ & 4 & $1.4 \mathrm{E}-09$ & $2.3 \mathrm{E}-09$ \\
$\mathrm{C}-08-5-4-531$ & 7 & $\mathrm{Y}$ & 4 & $2.6 \mathrm{E}-07$ & $3.6 \mathrm{E}-07$ \\
$\mathrm{C}-08-5-8-552$ & 4 & $\mathrm{~N}$ & 8 & $2.5 \mathrm{E}-08$ & $4.4 \mathrm{E}-08$ \\
$\mathrm{C}-08-5-8-555$ & 4 & $\mathrm{Y}$ & 8 & $2.4 \mathrm{E}-09$ & $3.8 \mathrm{E}-09$ \\
$\mathrm{C}-08-5-12-576$ & 4 & $\mathrm{~N}$ & 12 & $1.5 \mathrm{E}-09$ & $2.6 \mathrm{E}-08$ \\
$\mathrm{C}-08-5-12-580$ & 4 & $\mathrm{Y}$ & 12 & $1.4 \mathrm{E}-09$ & $1.7 \mathrm{E}-09$ \\
\hline
\end{tabular}

Re and I soil diffusivities by $\sim 1.5$ and $\sim 3$ times as compared to diffusivities in soil cores contacting concrete half cells with no Fe content. Rhenium diffusivity in soil cores in contact with noncarbonated concrete half cells with $12 \% \mathrm{Fe}$ was about an order of magnitude lower than in soil cores in contact with similar concrete half cells containing no Fe.

In soil cores (7\% moisture content) contacting Fe-free concrete with and without carbonation, the Re and I diffusivities were more than an order of magnitude higher than in soils containing $4 \%$ moisture content.

At the end of the experiment lasting over a year, Re and I diffusion in soil cores with $15 \%$ moisture content had proceeded to the degree that no distinct concentration gradients were present; therefore, diffusivity values could not be ascertained.

The summary observations from these tests are;

- Irrespective of the state of carbonation of spiked fractured concrete half cells, the Re and I diffusivities in soil with $4 \%$ moisture content were one to two orders of magnitude lower than in soil containing 7\% moisture content, indicating that fractured concrete in contact with soils with increasing moisture content substantially increases the diffusivity of Re and I.

- Generally, increasing Fe additions to untreated and carbonated fractured concrete half cells significantly reduced Re and I diffusivities in soils irrespective of moisture content.

- Rhenium and I diffusivities in soil cores (7\% moisture content) contacting Fe-free concrete with and without carbonation, were about two orders of magnitude higher than in soils with $4 \%$ moisture content. 


\subsection{Modeling the Diffusion of lodine and Technetium from a Reservoir Through a Concrete Enclosure and into Surrounding Soil}

To model the diffusion of iodine and technetium through 6 inches of concrete into the surrounding soil, pairs of high- and low-diffusivity values were selected from the experimental data. The values selected are listed in Table 12.1

Table 12.1. Diffusivity values for concrete and soil used in the simulations

\begin{tabular}{|c|c|c|c|}
\hline Diffusing Component & Material & Low Diffusivity, $\mathrm{cm}^{2} / \mathrm{s}$ & High Diffusivity, $\mathrm{cm}^{2} / \mathrm{s}$ \\
\hline \multirow[t]{2}{*}{ Iodine } & Concrete & $1.30 \mathrm{E}-10$ & $2.30 \mathrm{E}-09$ \\
\hline & Soil & $1.70 \mathrm{E}-09$ & $2.50 \mathrm{E}-08$ \\
\hline \multirow[t]{2}{*}{ Tc } & Concrete & $3.10 \mathrm{E}-11$ & $3.60 \mathrm{E}-10$ \\
\hline & Soil & $1.30 \mathrm{E}-08$ & $5.80 \mathrm{E}-08$ \\
\hline
\end{tabular}

\subsection{Modeling Approach}

The computational fluid dynamics (CFD) code, STAR-CD ${ }^{1}$ was used for the calculations. STAR-CD is a commercial CFD code that solves the finite volume formulations for conservation of mass, momentum, and energy for general-purpose thermal-fluids simulations. STAR-CD was used to simulate the Iodine and Technetium (Tc) species diffusion through the concrete encasement box and into the soil using the analogy of thermal conduction,

$$
\frac{d T}{d t}=\frac{k}{\rho C_{p}} \frac{d^{2} T}{d x^{2}}
$$

and mass diffusion:

$$
\frac{d C}{d t}=D \frac{d^{2} C}{d x^{2}}
$$

In the heat conduction equation (1) $T$ is the absolute temperature in Kelvin, $\rho$ is the density, and $C_{p}$ is the specific heat of the material. In the mass diffusion equation (2) $C$ is the specie concentration and $D$ is the specie diffusivity. In STAR-CD we can simulate the specie diffusion through the porous concrete and soil by setting the coefficients of (12.1) and (12.2) as equal and solving the thermal conduction problem through the two materials.

The following assumptions were made for performing the simulations:

- Constant specie concentration reservoir exists adjacent to inside wall of concrete encasement box.

- 1-dimensional diffusion through encasement box wall and into the surrounding soil.

- No additional resistance between concrete and soil to decrease the specie diffusion.

${ }^{1}$ STAR-CD, Version 4.14 Methodology2010: Computational Dynamics Ltd. 
A one-dimensional (1-D) finite volume model was constructed to represent the species transport through the concrete encasement wall and into the soil. A 1-D rectangular mesh was used for transport through the encasement wall. As the species exit the concrete and enter the surrounding soil, the environment is more cylindrical in nature as the species are free to diffuse radially into the soil. Thus the mesh for the concrete wall was mated to a cylindrical mesh extending out into the surrounding soil as shown schematically in Figure 12.1. The model domain is shown outlined with a dashed line in the figure. In the model, the concrete wall is assumed to be in contact with a constant specie reservoir (at location 1 in the figure). The contact between concrete and soil (at location 2 in the figure) is assumed to be perfect with no additional resistance there for specie diffusion. The outer radius of the model was established far away from the reservoir such that specie concentration remained zero for the times examined (1000, 3000,10000 , and 30000 years). Simulations were performed for diffusion of Iodine and Tc under lowdiffusivity and high-diffusivity conditions (Table 12.1)

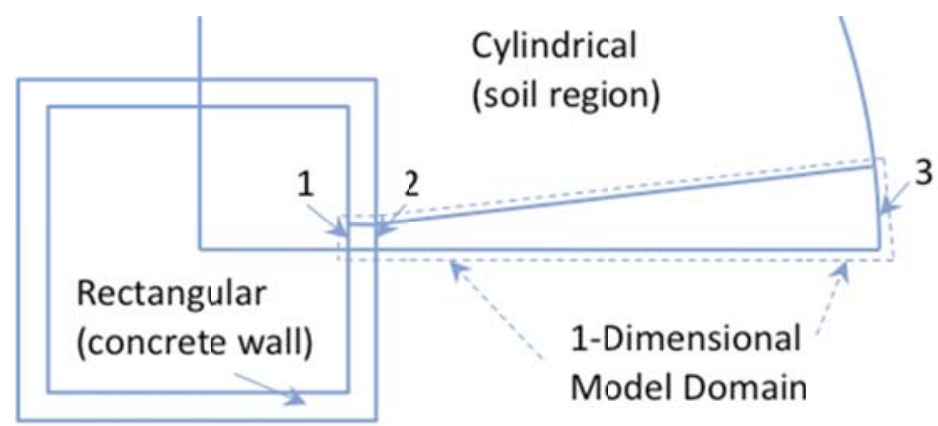

Figure 12.1. Plan-view schematic of the model domain (dashed outline) where the rectangular concrete encasement wall is in contact with the surrounding soil region into which the species diffuse radially. 1. Concrete wall in contact with specie reservoir. 2. Concrete in contact with soil. 3. Outer radius is established far enough away from the reservoir that species concentration is zero at long times (i.e., 3E4 years).

\subsection{Results}

The results of the simulations are listed in Tables 12.2 and 12.3 and the diffusion profiles are shown in Figures 13.2 through 13.5.

The normalized concentrations $\left(\mathrm{C} / \mathrm{C}_{0}\right)$ at the concrete $(6$ inches thick) soil interface as a function of time are listed in Table 12.2. The data indicates that under low diffusivity conditions, the $\mathrm{C} / \mathrm{C}_{0}$ for both $\mathrm{I}$ and Tc at all simulated times are very low $(0-0.07)$. Under high diffusivity conditions, the $\mathrm{C} / \mathrm{C}_{0}$ values for $\mathrm{Tc}$ ranged from $0-0.03$, whereas, iodine had $\mathrm{C} / \mathrm{C}_{0}$ values ranging from $0.05-0.22$ indicating deeper penetration into concrete.

Table 12.2. Normalized concentration values for I and Tc at the concrete-soil interface

\begin{tabular}{lcccc}
\hline & \multicolumn{4}{c}{ Time $(\mathrm{Y})$} \\
\cline { 2 - 5 } \multicolumn{1}{c}{ Diffusivity } & 1,000 & 3,000 & 10,000 & 30,000 \\
\cline { 2 - 5 } & \multicolumn{5}{c}{${\mathrm{C} / \mathrm{C}_{0}}$} \\
\hline I Low & 0.00 & 0.00 & 0.02 & 0.07 \\
I high & 0.05 & 0.10 & 0.17 & 0.22 \\
Tc Low & 0.00 & 0.00 & 0.00 & 0.00 \\
Tc High & 0.00 & 0.01 & 0.02 & 0.03 \\
\hline
\end{tabular}


The depths of penetration, defined as $\mathrm{C} / \mathrm{C}_{0}$ of $\sim 0.005$ for various simulated time periods, are listed in Table 12.3. Under low diffusivity conditions, iodine at the end of $30 \mathrm{~K}$ years is predicted to penetrate about 27 inches into soil (Table 12.3 and Figure 12.2), whereas Tc appears to be confined within the encasing of 6-inchethick concrete (Table 12.3 and Figure 12.4). Under higher diffusivity conditions, the simulations indicated higher depths of penetration of I and Tc into soil. For instance, iodine is predicted to penetrate from $\sim 15-160$ inches into the soil for the time period ranging from 1-30K years (Table 12.3, Figure 12.3). Technetium under high diffusivity conditions is predicted to penetrate $\sim 113-194$ inches into the soil at the end of $10 \mathrm{~K}$ and $30 \mathrm{~K}$ years respectively (Table 12.3, Figure 12.5).

Table 12.3. Depth of penetration I and Tc into soil as a function of time

\begin{tabular}{lcccc}
\hline & \multicolumn{4}{c}{ Time $(\mathrm{Y})$} \\
\cline { 2 - 5 } Diffusivity & 1,000 & 3,000 & 10,000 & 30,000 \\
\cline { 2 - 5 } & \multicolumn{4}{c}{ Depth of Soil Penetration at $\mathrm{C} / \mathrm{C}_{0}=\sim 0.005$} \\
\hline I Low & 0 & 0 & 7 & 27 \\
I high & 15 & 39 & 85 & 157 \\
Tc Low & 0 & 0 & 0 & 0 \\
Tc High & 0 & 0 & 44 & 113 \\
\hline
\end{tabular}

The experimental data indicates that low diffusivity for I is engendered when carbonated encasing concrete is surrounded by soil with very low moisture contents. For Tc, low diffusivity is observed when carbonated and Fe-containing concrete is in contact with very low moisture content sediments.

Comparatively, higher diffusivities of I and Tc are typically observed when higher moisture content soil is in contact with uncarbonated, Fe-free encasing concrete.

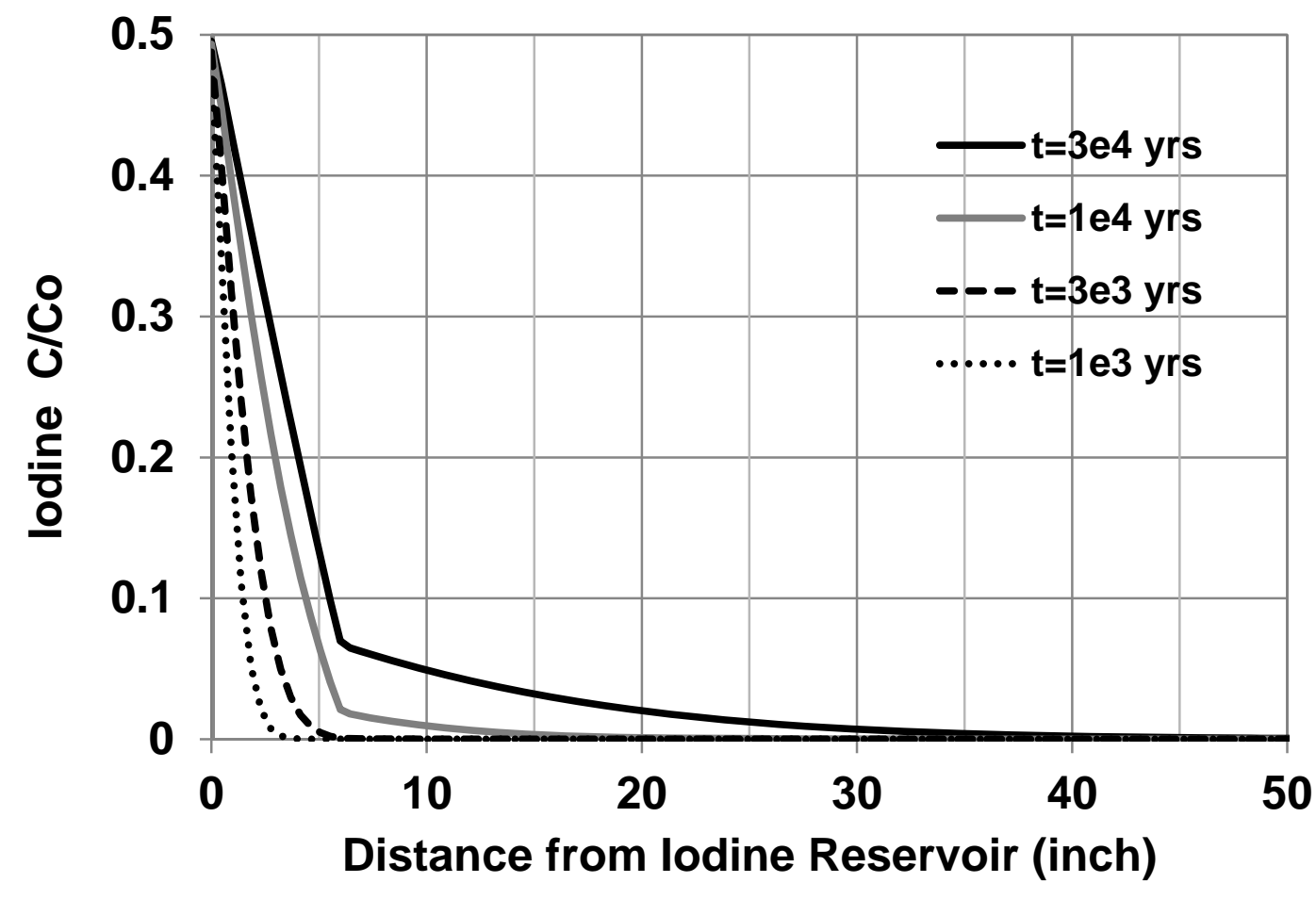


Figure 12.2. Iodine concentration profiles for the low diffusivity case. Zero to six inches represents concentrations within the concrete encasement wall. Six inches and beyond are concentrations in the surrounding soil. $\mathrm{C} / \mathrm{C}_{0}=0.005$ was about 27 inches into the soil at $\mathrm{t}=3 \mathrm{E} 4$ years.

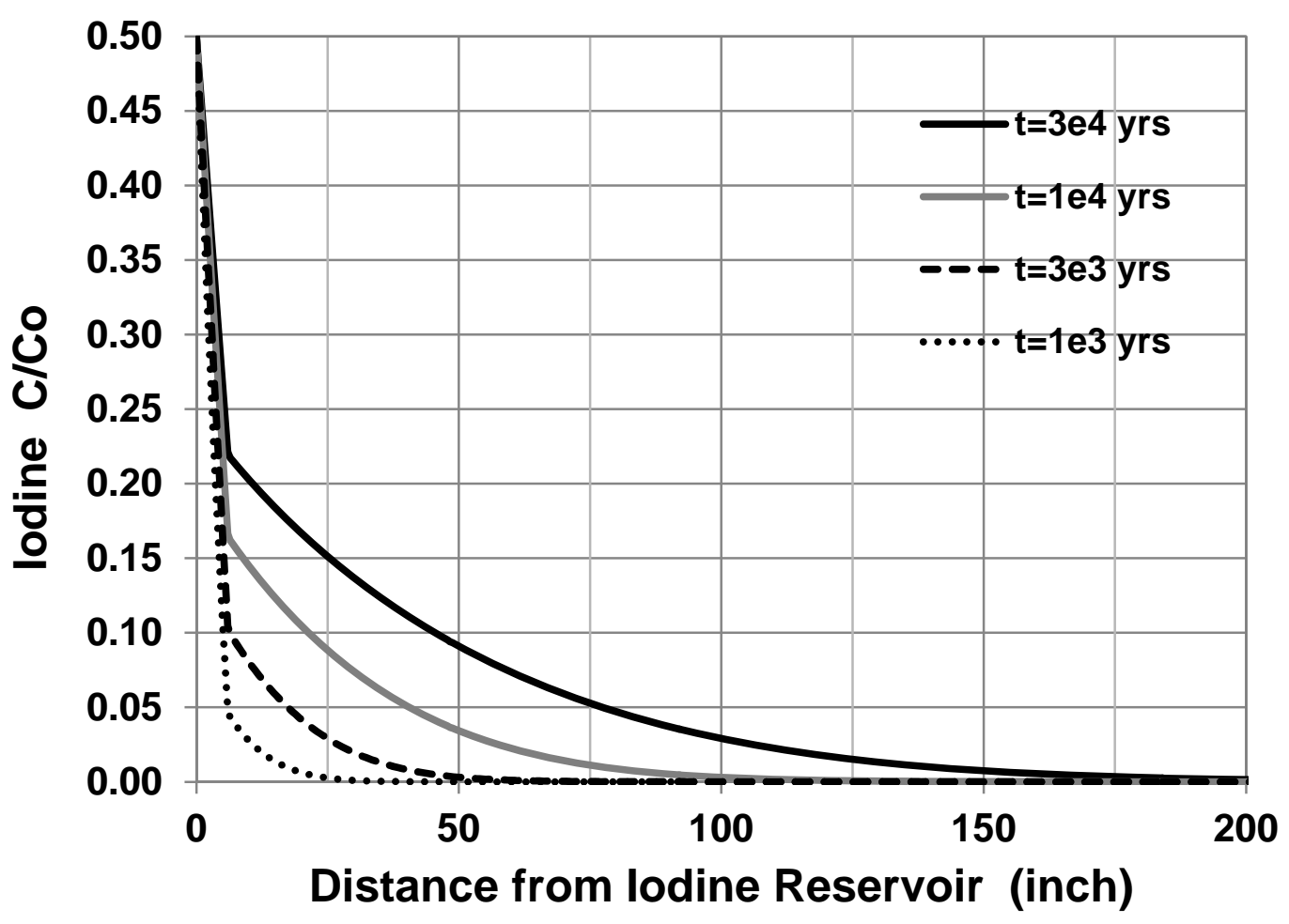

Figure 12.3. Iodine concentration profiles for the high diffusivity case. Zero to six inches represents concentrations within the concrete encasement wall. Six inches and beyond are concentrations in the surrounding soil. $\mathrm{C} / \mathrm{C}_{0}=0.005$ was about 157 inches into the soil depth at $\mathrm{t}=3 \mathrm{E} 4$ years. 


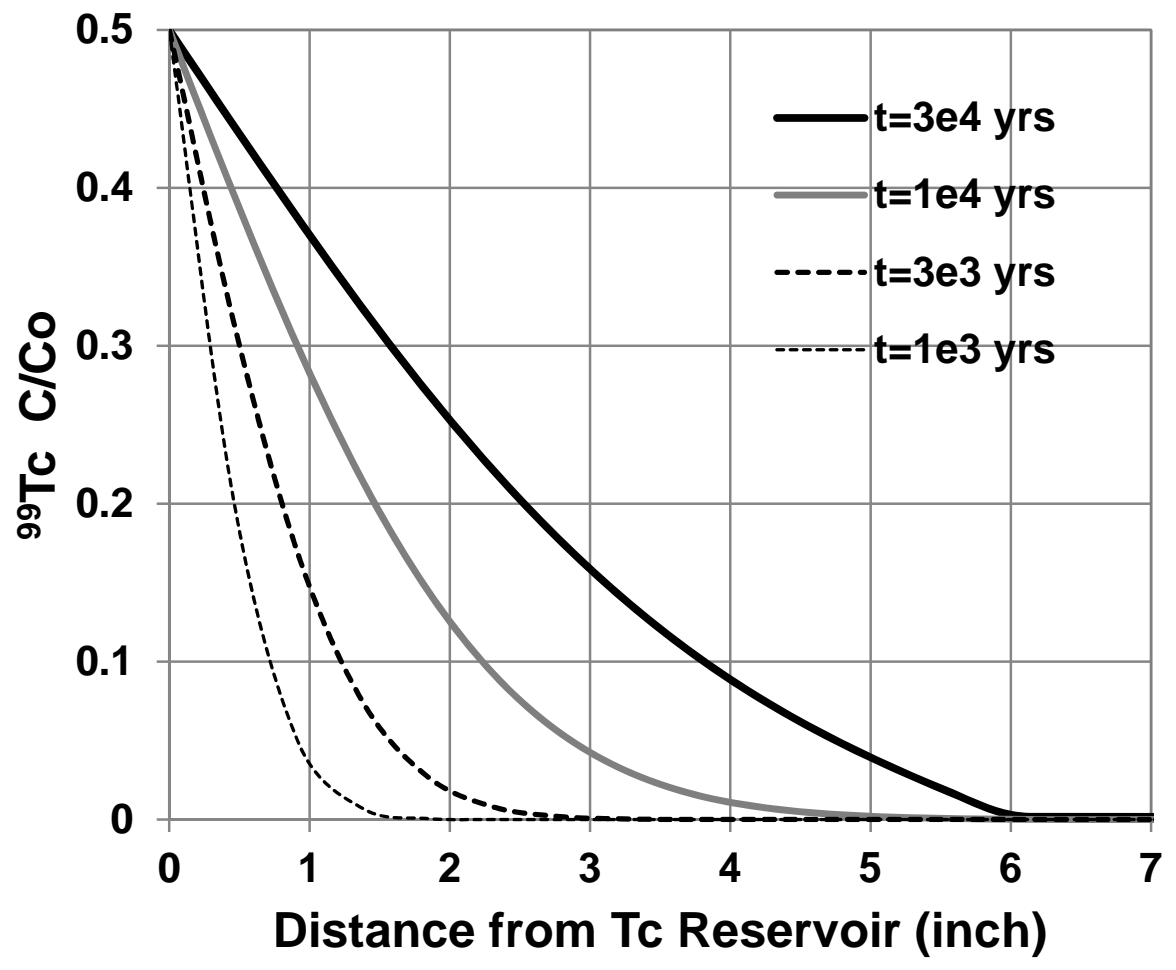

Figure 12.4. Technetium concentration profiles for the low diffusivity case. Zero to six inches represents concentrations within the concrete encasement wall. Six inches and beyond are concentrations in the surrounding soil. $\mathrm{C} / \mathrm{C}_{0}=0.005$ was about to the outer edge of the concrete encasement ( 6 inches total penetration depth) at $\mathrm{t}=3 \mathrm{E} 4$ years. 


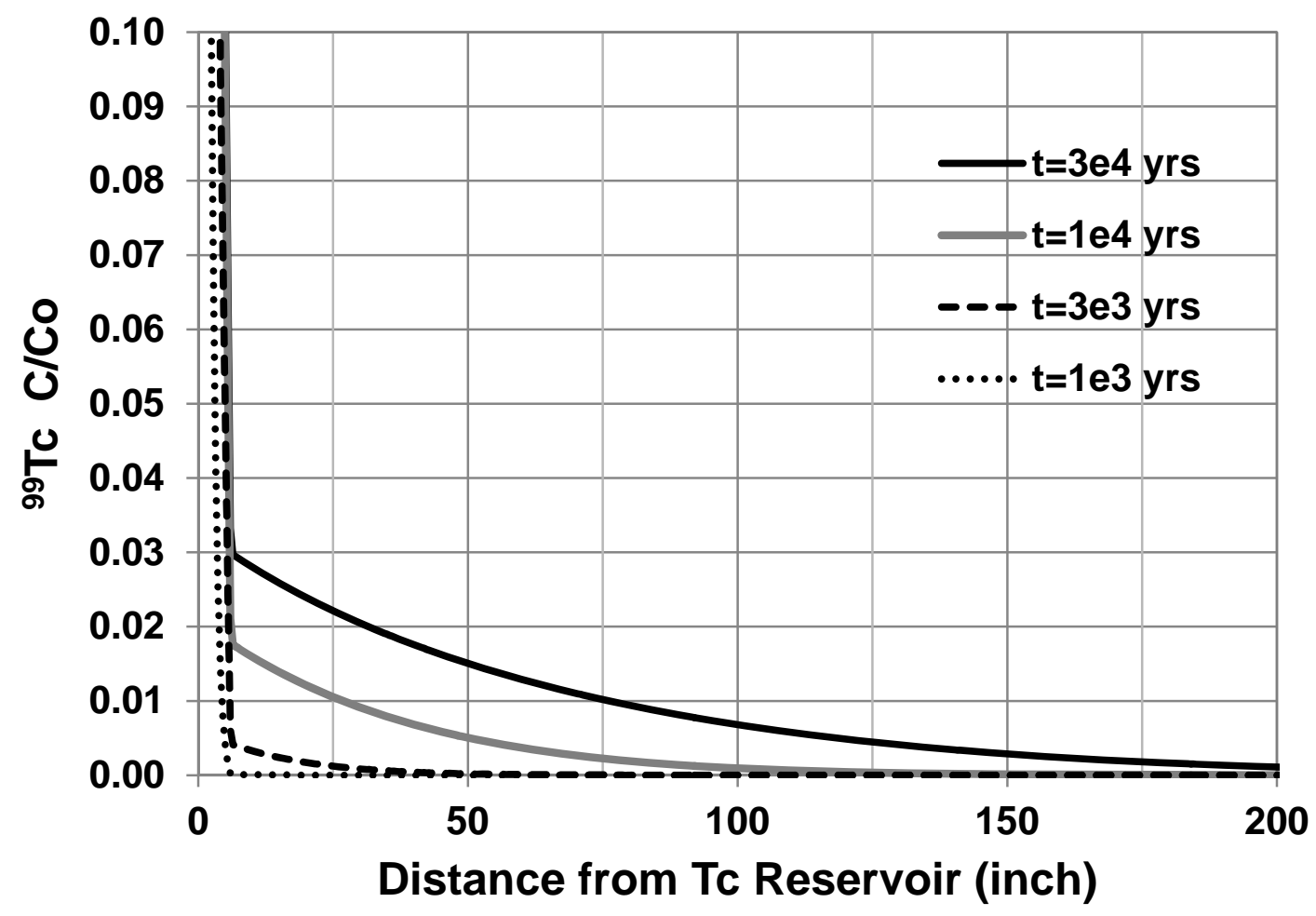

Figure 12.5. Technetium concentration profiles for the high diffusivity case. Zero to six inches represents concentrations within the concrete encasement wall. Six inches and beyond are concentrations in the surrounding soil. $\mathrm{C} / \mathrm{C}_{0}=0.005$ was about 113 inches into the soil at $\mathrm{t}=3 \mathrm{E} 4$ years. 


\subsection{Leaching and Diffusion Data Summary}

Specimens of concrete waste forms designed to safely dispose of Category 3 low-level radioactive wastes in the vadose zone at the Hanford Site were tested for their leaching characteristics and the diffusivity of radionuclides of interest in concrete waste forms and the surrounding, entombing, relatively dry sediments. The results of these tests are as follows.

\subsection{Leaching Tests}

- The first set of experiments indicated that I leached significantly less (LI: 10.0) as compared to Tc (LI: 8.4 ) and use of $4 \%$ by mass of steel fiber did not noticeably affect the leachability of either I or Tc.

- Use of increasing mass of Fe particles (4, 8, and 12\% of $40-60$ mesh size) did not affect the leachability of either I (LI: 9.1 -9.6) or Re (LI: 9.3 - 9.7) indicating the ineffectiveness of Fe particles to retard the leaching of these contaminants perhaps due to potential passivation of the metallic Fe surface by oxide layers. However, inclusion of RNIP relative to metallic Fe particles showed increases of up to an order of magnitude in leachability of Tc (LI: 7.7 - 7.9), Re (LI: $7.9-$ 9.3) and I (LI: 7.9 - 9.0). The presence of polymeric dispersants in RNIP may be a cause for this enhanced leaching.

\subsection{Concrete Carbonation Studies}

- Specimens of historic above-ground, cored concrete specimens showed increased depth of carbonation with age. Depths of carbonation of $1-10 \mathrm{~mm}, 2-8 \mathrm{~mm}$ and $48-53 \mathrm{~mm}$ were measured for concrete specimens that were 14,28 , and 57 year old respectively.

- Use of supercritical carbon dioxide generated $1-8 \mathrm{~mm}$ of carbonation; however, petrographic examination revealed cracks ranging $8-10 \mu \mathrm{m}$ in width within the carbonated region.

- All concrete cores buried in samples of vadose zone sediments (4, 7, and 15\% moisture content) carbonated on average to a depth of $0.3 \mathrm{~mm}$ in about 6 months.

\subsection{Diffusion of ${ }^{125} \mathrm{I}$ and ${ }^{99} \mathrm{Tc}$ in Soil-Soil and Concrete-Soil Half Cells}

- Increasing moisture content from $4 \%$ to $7 \%$ increased the diffusivities of both ${ }^{125} \mathrm{I}$ and ${ }^{99} \mathrm{Tc}$ by about an order of magnitude.

- The diffusivity of ${ }^{125} \mathrm{I}$ increased from $1.7 \times 10^{-8} \mathrm{~cm}^{2} / \mathrm{s}$ in $4 \%$ initial moisture content soil to $1.3 \times 10^{-7}$ $\mathrm{cm}^{2} / \mathrm{s}$ in $7 \%$ initial moisture content soil. Similarly, the diffusivity of ${ }^{99} \mathrm{Tc}$ increased from $\sim 1.5 \times 10^{-8}$ $\mathrm{cm}^{2} / \mathrm{s}$ in $4 \%$ initial moisture content soil to $\sim 1.1 \times 10^{-7} \mathrm{~cm}^{2} / \mathrm{s}$ in $7 \%$ initial moisture content soil.

- The diffusivity in concrete calculated by concentration-profile fitting for the spiked soil half cell yielded a value of $1.31 \times 10^{-12} \mathrm{~cm}^{2} / \mathrm{s}$ for ${ }^{125} \mathrm{I}$ and values ranging from $4.54 \times 10^{-13} \mathrm{~cm}^{2} / \mathrm{s}$ to $4.54 \times 10^{-11}$ $\mathrm{cm}^{2} / \mathrm{s}{ }^{99} \mathrm{Tc}$, respectively. These values are considered to be approximations because the radionuclide concentrations in the concrete half cells were not measured directly. 


\section{Effect of Supercritical Carbonation and Metallic Iron Addition on I and Re Diffusion in Soils}

- The diffusivity of Re and I in low moisture (4\%) soil ranged from $1.3-2.9 \times 10^{-9} \mathrm{~cm}^{2} / \mathrm{s}$ and $1.9 \times 10^{-9}-4.5 \times 10^{-8} \mathrm{~cm}^{2} / \mathrm{s}$, respectively.

- In higher moisture content soil (7\%), the diffusivities were about an order of magnitude higher for both $\operatorname{Re}\left(3.3-5.8 \times 10^{-8} \mathrm{~cm}^{2} / \mathrm{s}\right)$ and I $\left(3.9-6.3 \times 10^{-8} \mathrm{~cm}^{2} / \mathrm{s}\right)$.

- Micro-cracking of source concrete from supercritical carbonation on average appeared to enhance diffusivities of Re and I in soils.

- The presence of low concentration of iron fibers did not seem to significantly affect the diffusivity of either rhenium or iodine.

\subsection{Effect of Solution Carbonation and Metallic Iron Addition on I and Tc Diffusion in Concrete}

- Noticeable attenuation of ${ }^{99} \mathrm{Tc}$ and I diffusivities occurred in concrete half cells that were carbonated by treating with sodium carbonate solution.

- Generally, addition of Fe particles to both uncarbonated and carbonated concrete also resulted in about an order of magnitude reduction in ${ }^{99} \mathrm{Tc}$ and I diffusivities.

- Based on previous studies, attenuation of ${ }^{99} \mathrm{Tc}$ diffusivities upon Fe addition can be attributable to reduction of ${ }^{99} \mathrm{Tc}(\mathrm{VII})$ to relatively insoluble ${ }^{99} \mathrm{Tc}(\mathrm{IV})$ solid forms, whereas mechanisms of similar attenuation of I diffusivity upon Fe addition need further investigation.

\subsection{Diffusion of lodine and Rhenium from Soil into Fractured Concrete}

- The calculated diffusivities for Re ranged from $3.8 \times 10^{-12}$ to $2 \times 10^{-9} \mathrm{~cm}^{2} / \mathrm{s}$ and for I ranged from 1.3 $\mathrm{x} 10^{-10}$ to $2.3 \times 10^{-9} \mathrm{~cm}^{2} / \mathrm{s}$ in fractured concrete. The highest Re and I diffusivities were observed in fractured concrete cores that were in contact with spiked soils with $15 \%$ moisture content.

- Additions of $4 \%$ by weight Fe did not noticeably affect the diffusivities of Re and I in fractured concrete.

- The diffusivity of Tc in fractured concrete cores ranged from $3.1 \times 10^{-11} \mathrm{~cm}^{2} / \mathrm{s}$ to $3.6 \times 10^{-10} \mathrm{~cm}^{2} / \mathrm{s}$. Carbonation in all cases increased the Tc diffusion coefficient. The beneficial effect of Fe on reducing Tc diffusivity in non-carbonated specimens was not observable until the Fe content was at least $8 \%$ by mass.

- Due to the mode of fracture induction, the induced fractures are random by nature; therefore the number of fractures and the fracture geometry in the cement cores are not replicable from core to core. 


\subsection{Diffusion of lodine and Rhenium from Fractured Concrete into Soil}

- Irrespective of the state of carbonation of spiked fractured concrete half cells, the Re and I diffusivities in soil with $4 \%$ moisture content were one to two orders of magnitude lower than in soil containing 7\% moisture content, indicating that fractured concrete in contact with soils with increasing moisture content substantially increases the diffusivity of Re and I.

- Generally, increasing Fe additions to untreated and carbonated fractured concrete half cells significantly reduced Re and I diffusivities in soils irrespective of moisture content.

- Rhenium and I diffusivities in soil cores (7\% moisture content), contacting Fe-free concrete with and without carbonation, were about two orders of magnitude higher than in soils with $4 \%$ moisture content.

\subsection{Modeling Diffusion of Iodine and Technetium in Concrete and Soil}

- Modeling shows that under low diffusivity conditions, the $\mathrm{C} / \mathrm{C}_{0}$ at concrete for both $\mathrm{I}$ and $\mathrm{Tc}$ at all simulated times are very low $(0-0.07)$. Under high diffusivity conditions, the $\mathrm{C} / \mathrm{C}_{0}$ values for $\mathrm{Tc}$ ranged from $0-0.03$, whereas, iodine had $\mathrm{C} / \mathrm{C}_{0}$ values ranging from $0.05-0.22$ indicating deeper penetration into concrete.

- Under low diffusivity conditions, iodine at the end of $30 \mathrm{~K}$ years, is predicted to penetrate $\left(\mathrm{C} / \mathrm{C}_{0}\right.$ of $\sim 0.005$ ) about 27 inches into the soil, whereas Tc appears to be confined within the encasing of 6inch-thick concrete. Under higher diffusivity conditions, iodine is predicted to penetrate from $\sim 15-$ 160 inches into the soil for the time period ranging from $1-30 \mathrm{~K}$ years. Comparatively, technetium under high diffusivity conditions is predicted to penetrate $\sim 44-113$ inches into the soil at the end of $10 \mathrm{~K}$ and $30 \mathrm{~K}$ years, respectively. 



\subsection{Conclusions}

Tests were conducted to measure the diffusion of $\mathrm{Tc}, \mathrm{Re}$ (as a surrogate for $\mathrm{Tc}$ ) and $\mathrm{I}$, in unsaturated sediments and in concrete that encases Category 3 low-level radioactive wastes. In these tests, effects of varying sediment moisture content, carbonation, metallic iron addition, and fracturing of concrete on diffusivity of these nuclides were also evaluated. The conclusions from these tests are as follows.

1. Regardless of the variables introduced in the analysis (e.g., water content of the sediment, level of iron additives and carbonation of concrete), diffusion coefficients for both Tc and I varied over a range of about 2 orders of magnitude with Tc being slightly more retarded than I.

2. Degradation of concrete through fracturing and carbonation will not strongly influence diffusion rates primarily because of expected low moisture contents in the waste environment (vadose zone sediments).

3. Within the range of measurements, increasing moisture content of the sediment routinely increased diffusion rates.

4. The addition of metallic iron appeared to have competing effects on diffusion. In some cases, limited reduction of Tc may have occurred. On the other hand, metallic iron appears to have facilitated microcracking during carbonation.

5. Carbonation of concrete using supercritical carbon dioxide speeds up the natural carbonation process however, the resulting concrete characteristics are not representative of natural carbonation of concrete in the vadose zone.

6. In the context of a 1,000 year compliance period, concrete encasement of waste provides a significant delay in radionuclide release into the subsurface. 



\section{References}

Al-Khayat H, MN Haque, and NI Fattuhi. 2002. "Concrete Carbonation in Arid Climate." Materials and Structures 35(7):421-426.

ANSI. 1986. Measurement of the Leachability of Solidified Low-Level Radioactive Wastes by a ShortTerm Test Procedure, ANSI/ANS-16.1, American Nuclear Society, Chicago.

Atkinson A and AK Nickerson. 1988. "Diffusion and Sorption of Cesium, Strontium, and Iodine in Water-Saturated Cement." Nucl. Technol. 81:100-113.

Brown DA, BE Fulton and RE Phillips. 1964. "Ion Exchange Diffusion: I. A Quick-Freeze Method for the Measurement of Ion Diffusion in Soil and Clay Systems." Soil Sci. Soc. Am. Proc. 28:628-632.

Crane PJ, HL Benny and MI Wood. 1992. Physical Modeling of Contaminant Diffusion from a Cementitious Waste Form. WHC-SA-1345-FP. Westinghouse Hanford Company, Richland, Washington.

Crank J. 1975. The Mathematics of Diffusion. Second Edition. Oxford University Press, New York.

EPA-U.S. Environmental Protection Agency. 1999. Toxicity Characteristics Leaching Procedure. Test Methods for Evaluating Solid Wastes - Physical and Chemical Methods SW-846. Method 1311.

Finney DJ. 1971. Probit Analysis; A Statistical Treatment of the Sigmoid Response Curve. Third edition, Cambridge University Press, New York.

Garrabrants AC, and DS Kosson. 2003. "Modeling Moisture Transport from a Portland Cement-Based Material During Storage in Reactive and Inert Atmospheres.” Drying Technology 21(5):775-805.

Garrabrants AC, F Sanchez, C Gervais, P Moszkowicz, and DS Kosson. 2002. "The Effect of Storage in an Inert Atmosphere on the Release of Inorganic Constituents during Intermittent Wetting of a CementBased Material." Journal of Hazardous Materials 91(1-3):159-185.

Garrabrants AC, F Sanchez, and DS Kosson. 2004. "Changes in Constituent Equilibrium Leaching and Pore Water Characteristics of a Portland Cement Mortar as a Result of Carbonation." Waste Management 24(1):19-36.

Gervais C, AC Garrabrants, F Sanchez, R Barna, P Moszkowicz, and DS Kosson. 2004. "The Effects of Carbonation and Drying During Intermittent Leaching on the Release of Inorganic Constituents from a Cement-Based Matrix." Cement and Concrete Research 34(1):119-131.

Lamar DA. 1989. Measurement of Nitrate Diffusivity in Hanford Sediments via the Half-Cell Method. Letter Report to Westinghouse Hanford Company, Pacific Northwest National Laboratory, Richland, Washington. 
Mann FM, RJ Puigh II, SH Finfrock, EJ Freeman, R Khaleel, DH Bacon, MP Bergeron, PB McGrail, and SK Wurstner. 2001. Hanford Immobilized Low-Activity Waste Performance Assessment: 2001 Version, DOE/ORP-2000-24, Rev. B. Pacific Northwest National Laboratory, Richland, WA.

Martin, PF, RJ. Serne, VL Legore, CW. Lindenmeier. 1994. Status Report on Ionic Diffusion Through Asphalt. Letter Report to Westinghouse Hanford Company. HGTP-93-0602-01, Pacific Northwest Laboratory, Richland, Washington.

Mattigod SV, GA Whyatt, RJ Serne, PF Martin, KE Schwab, and MI Wood. 2001. Diffusion and Leaching of Selected Radionuclides (Iodine-129, Technetium-99, and Uranium) through Category 3 Waste Encasement Concrete and Soil Fill Material. PNNL-13639, Pacific Northwest National Laboratory, Richland, WA.

Pourbaix, M. 1966. Atlas of Electrochemical Equilibria. Pergamon Press, Oxford, England.

Sanchez F, AC Garrabrants and DS Kosson. 2003. "Effects of Intermittent Wetting on Concentration Profiles and Release from a Cement-Based Waste Matrix." Environmental Engineering Science 20(2):135-153.

Sanchez F, C Gervais, AC Garrabrants, R Barna, and DS Kosson. 2002. "Leaching of Inorganic Contaminants from Cement-Based Waste Materials as a Result of Carbonation during Intermittent Wetting." Waste Management 22(2):249-260.

Serne RJ, WJ Martin, VL LeGore, CW Lindenmeier, SB McLaurine, PFC Martin, and RO Lokken. 1989. Leach Tests on Grouts Made with Actual and Trace Metal-Spiked Synthetic Phosphate/Sulfate Waste. PNL-7121, Pacific Northwest Laboratory, Richland, WA

Serne RJ, RO Lokken, and LJ Criscenti. 1992a. "Characterization of Grouted LLW to Support Performance Assessment." Waste Management 12(2-3):271-287.

Serne, RJ, LL Ames, PF Martin, VL LeGore, CW Lindenmeier, and SJ Phillips. 1992b. Leach Testing of in Situ Stabilization Grouts Containing Additives to Sequester Contaminants. PNL-8492, Pacific Northwest Laboratory, Richland, Washington.

Serne RJ, JL Conca, VL LeGore, KJ Cantrell, CW Lindenmeier, JA Campbell, JE Amonette, and MI Wood. 1993. Solid-Waste Leach Characterization and Contaminant-Sediment Interactions. Volume 1, Patch Leach and Adsorption Tests and Sediment Characterization. PNL-8889, Pacific Northwest Laboratory, Richland, WA.

Serne RJ, WJ Martin, and VL LeGore. 1995. Leach Test of Cladding Removal Waste Grout Using Hanford Groundwater. PNL-10745, Pacific Northwest Laboratory, Richland, WA.

Wellman DM, SV Mattigod, GA Whyatt, L Powers, KE Parker, LN Clayton, and MI Wood. 2006. Diffusion of Iodine and Rhenium in Category 3 Waste Encasement Concrete and Soil Fill Material, PNNL-16268, Pacific Northwest National Laboratory, Richland, WA. 
Wellman DM, CC Bovaird, SV Mattigod, KE Parker, RM Ermi, and MI Wood. 2008. Effect of Concrete Waste Form Properties on Radionuclide Migration. PNNL-17808, Pacific Northwest National Laboratory, Richland, WA.

Wood, MI, R Khaleel, PD Rittman, AH Lu, SH Finfrock, TH DeLorenzo, RJ Serne, and KJ Cantrell. 1995. Performance Assessment for the Disposal of Low-Level Waste in the 200 West Area Burial Ground. WHC-EP-0645, Westinghouse Hanford Company, Richland, Washington. 



\section{Distribution}

No. of

Copies

1 Local Distribution

Pacific Northwest National Laboratory

SV Mattigod

K3-62

CC Bovaird

K3-62

DM Wellman

K3-62

MI Wood

H8-51

Distr.1 




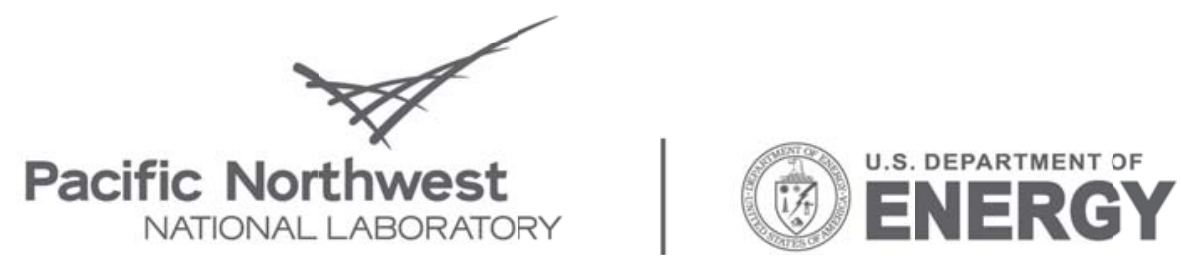

Proudly Operated by Battelle Since 1965

902 Battelle Boulevard

P.O. Box 999

Richland, WA 99352

1-888-375-PNNL (7665)

www.pnl.gov 